\author{
UNIVERSIDADE DE SÃO PAULO \\ INSTITUTO DE FÍSICA \\ INSTITUTO DE QUÍMICA \\ INSTITUTO DE BIOCIÊNCIAS \\ FACULDADE DE EDUCAÇÃO
}

Marcos Paulo Hirayama

\title{
As concepções de professores de química sobre a utilização de elementos da história e filosofia da ciência no ensino
}

São Paulo 


\section{MARCOS PAULO HIRAYAMA}

\section{As concepções de professores de química sobre a utilização de elementos da história e filosofia da ciência no ensino}

Dissertação apresentada ao Instituto de Física, Instituto de Química, Instituto de Biociências e à Faculdade de Educação da Universidade de São Paulo para a obtenção do título de Mestre em Ensino de Ciências.

Área de Concentração: Ensino de Química

Orientador: Prof. Dr. Paulo Alves Porto

Versão corrigida. A versão original encontrase disponível tanto na Biblioteca do IF quanto na Biblioteca Digital de Teses e Dissertações da USP (BDTD)

São Paulo 
Autorizo a reprodução e divulgação total ou parcial deste trabalho por qualquer meio convencional ou eletrônico, para fins de estudo e de pesquisa, desde que citada a fonte.

\section{FICHA CATALOGRÁFICA \\ Preparada pelo Serviço de Biblioteca e Informação do Instituto de Física da Universidade de São Paulo}

Hirayama, Marcos Paulo

As concepções de professores de química sobre a utilização de elementos da história e filosofia da ciência no ensino. São Paulo, 2015.

Dissertação (Mestrado) - Universidade de São Paulo. Faculdade de Educação, Instituto de Física, Instituto de Química e Instituto de Biociências.

Orientador: Prof. Dr. Paulo Alves Porto

Área de Concentração: Ensino de Química.

Unitermos: 1.Química - Estudo e ensino; 2.História da ciência; 3.Filosofia da ciência; 4.Química - Filosofia; 5.Concepções docentes; 6.Professores de química. 
Aos meus pais, Anatilde e Hiroshi.

Aos meus irmãos, Ana, Luiz e Isabela. 


\section{AGRADECIMENTOS}

Aos meus pais, Hiroshi e Anatilde, por sempre me incentivarem a estudar e apoiarem as minhas escolhas.

Aos meus irmãos, Ana Paula, Luiz, Isabela e à minha sobrinha Laura, pelos bons momentos durante os encontros familiares que me ajudaram a relaxar durante esse período intenso de leituras e reflexões.

Ao Prof. Paulo Porto, que com suas sugestões e orientações precisas e tranquilas amainou minha ansiedade, apontou os modos mais adequados para realizar esse trabalho e me proporcionou a autonomia necessária para o desenvolvimento como pesquisador.

Aos professores entrevistados, pela paciência e por terem dedicado algumas horas de seu valioso tempo para a realização das entrevistas.

Aos professores e amigos da pós em Jornalismo Científico da UNICAMP, especialmente ao Danilo Albergaria, pelas discussões sobre a ciência, as quais foram fundamentais para que eu passasse a considerar a relevância da história, da filosofia e da sociologia da ciência para o ensino.

Às amigas Roberta, Kátia, Renata e Zélia pelo companheirismo, pelos almoços inesquecíveis, por me incentivarem a ingressar no mestrado, por aguentarem as minhas reclamações e pelas discussões sobre educação e sociedade.

Ao melhor grupo de trabalho do qual já fiz parte, Cláudia, Guilherme Drummond e Tatiane, pela amizade incondicional, pelas discussões filosóficas sobre política, educação, literatura, vida, etc., assim como pelas boas risadas e conversas em nossos cafés da tarde. 
Aos amigos do Programa de Formação de Professores da Faculdade de Educação da USP, pelas discussões sobre educação, cultura e política, bem como pelo companheirismo nos bons e maus momentos.

Aos amigos do GHQ, especialmente ao Evandro e à Anielli, pelas dicas, sugestões e reflexões filosóficas (virtuais e presenciais) sobre a química, as quais contribuíram sobremaneira para a elaboração desta dissertação.

À minha amiga Aline e sua querida família, pelo incentivo e apoio incondicional em todos os momentos nos quais estivemos juntos.

À minha companheira Renata, pela paciência, por suportar meus momentos de mau humor e me incentivar a continuar, apesar dos obstáculos com os quais me deparava pelo caminho. 
Há, portanto, ações e experiências humanas as quais não se aplica a pergunta acerca da finalidade ("para que servem?").

Elas não têm necessariamente nenhuma utilidade imediata, muitas vezes, nem sequer visam atingir um "fim" exterior à própria atividade. Podem, contudo, ser dotadas de "sentido". As relações de amizade, a experiência da paternidade, o prazer de ler um poema são exemplos de experiências que podem ter um profundo sentido formativo para quem as vive, a despeito de sua vaga ou nula aplicabilidade prática imediata.

(José Sérgio Fonseca de Carvalho, 2013) 


\section{RESUMO}

Hirayama, M.P. As concepções de professores de química sobre a utilização de elementos da história e filosofia da ciência no ensino. 2015. 317f. Dissertação de Mestrado - Instituto de Física, Instituto de Química, Instituto de Biociências e Faculdade de Educação - Programa Interunidades em Ensino de Ciências, Universidade de São Paulo, São Paulo, 2015.

Nas últimas décadas, investigações têm destacado o papel da história e filosofia da ciência (HFC) na educação científica. $O$ reconhecimento da pluralidade $e$ complexidade da ciência tem originado estudos, os quais apontam que o ensino sobre ciências deve levar em conta as diferenças entre as disciplinas científicas. Assim, tem-se discutido a importância da consideração de elementos da história e da filosofia da química no aprimoramento do processo de ensino e aprendizagem dessa ciência. Apesar disso, investigações têm constatado que pouco ou nada se discute acerca desses assuntos nas aulas de ciências. Diante disso, esta dissertação tem como intuito investigar a concepção de professores de química sobre a inclusão de elementos da HFC no ensino, com foco nas características inerentes às práticas e aos conhecimentos químicos. Foram investigadas as concepções de cinco professores de química, que atuam em diferentes escolas públicas da região metropolitana de São Paulo, acerca de cinco temas, elaborados com base em estudos da área de ensino de ciências e em diretrizes curriculares oficiais: relações com a sociedade, modelos e modelagem, experimentação, desenvolvimento histórico e reducionismo. Por meio da análise qualitativa dos dados, as concepções docentes, para cada tema, foram classificadas em dois subeixos temáticos: prática docente e relevância. Ademais, foram identificados fatores externos e internos que influenciam as práticas e concepções dos sujeitos concernentes a considerações filosóficas, históricas e sociológicas sobre a química. Os resultados evidenciam que, de modo geral, os sujeitos consideram relevantes determinados assuntos relacionados à natureza da química e, em certa medida, buscam inseri-los em suas práticas cotidianas. Contudo, mostraram também que os motivos pelos quais os docentes conferem importância a algumas discussões, e 0 modo como as desenvolvem, podem limitar a compreensão dos estudantes sobre a complexidade da construção do conhecimento científico. Além disso, foram raras as referências a aspectos específicos da química, à importância de evidenciar e discutir esses aspectos com os estudantes, assim como à preparação de situações didáticas próximas à prática química autêntica.

Palavras-chave: História e Filosofia da Ciência. Filosofia da Química. Concepções docentes. Ensino de Química. Professores de Química. 


\begin{abstract}
Hirayama, M.P. Chemistry teachers' conceptions about the use of elements of history and philosophy of science in teaching. 2015. 317f. Dissertação de Mestrado - Instituto de Física, Instituto de Química, Instituto de Biociências e Faculdade de Educação - Programa Interunidades em Ensino de Ciências, Universidade de São Paulo, São Paulo, 2015.

In recent decades, research has highlighted the role of history and philosophy of science (HFC) in science education. The recognition of the plurality and complexity of science originated studies showing that the teaching of science must take into account the differences between scientific disciplines. Thus, the importance of considering elements of the history and philosophy of chemistry in the improvement of science education has been the subject of discussions. Nevertheless, research has found that little or nothing is discussed about these issues in science classes. Therefore, this work aims at investigating chemistry teachers' conceptions on the inclusion of HFC elements in education, focusing on the characteristics of chemical knowledge and practices. Five chemistry teachers, working in different public schools in the metropolitan region of São Paulo, were interviewed about five themes related to research findings in the area of science education and to current curriculum guidelines: science and society relations, models and modeling, experimentation, historical development, and reductionism. By means of qualitative analysis, teachers' conceptions for each subject were classified into two subthemes: teaching practice and relevance. Furthermore, external and internal factors influencing practices and conceptions of the interviewees concerning philosophical, historical and sociological aspects of chemistry were identified. Results showed that, in general, the teachers considered some aspects of the nature of chemistry as being relevant and, to some extent, they seek to introduce such aspects into their classroom practices. However, results also showed that the reasons given by the teachers to justify some discussions, and the way they deal with such subjects in the classroom, may limit the students' understanding of the complexity of the construction of scientific knowledge. Also, the teachers made few references to peculiar aspects of chemistry, to the importance of showing and discussing such aspects with the students, as well as to the preparation of didactic situations close to the real practice of chemistry.
\end{abstract}

Keywords: History and Philosophy of Science. Chemical Philosophy. Conceptions teachers. Chemistry Teaching. Chemistry Teachers. 


\section{SUMÁRIO}

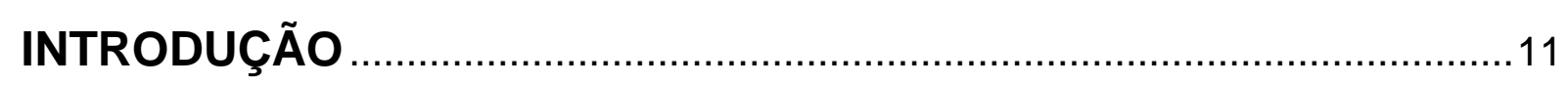

CAPÍTULO 1 - REFERENCIAIS TEÓRICOS ............................................14

1.1. A educação científica e a história e filosofia da ciência (HFC) ........................14

1.2. Natureza da ciência e a história e filosofia da ciência (HFC) ..........................16

1.2.1. História e filosofia da ciência ........................................................ 17

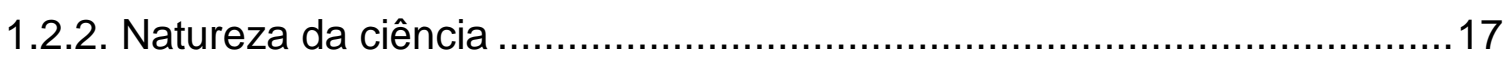

1.2.3. Natureza da ciência: aspectos consensuais na educação científica ........18

1.2.4. Natureza da ciência e HFC: abordagens didáticas ................................21

1.2.5. As críticas à visão consensual acerca da natureza da ciência ................23

1.3. A abordagem de aspectos da natureza da química ....................................25

1.3.1. A filosofia da química e o ensino de química ......................................27

1.3.2. A natureza da química e a educação química .......................................28

1.4. Natureza da ciência, natureza da química e a formação docente...................32

1.5. Dificuldades para a inclusão da HFC no ensino de ciências..........................34

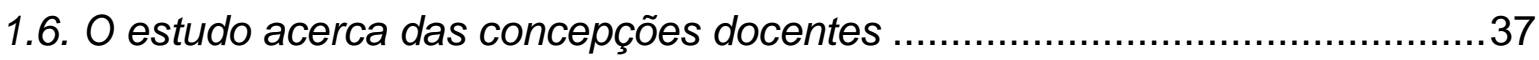

CAPÍTULO 02 - OBJETIVOS E METODOLOGIA .................................40

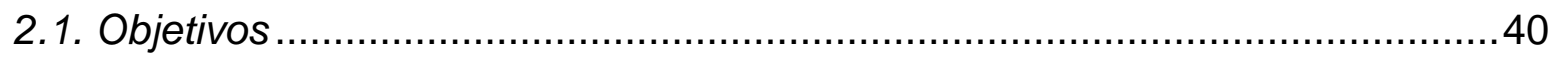

2.2. Percurso metodológico ................................................................ 40

2.2.1. Participantes do estudo ......................................................... 40

2.2.1.1. Caracterização dos sujeitos de pesquisa .....................................41

2.2.2. Recolha de dados ................................................................. 44

2.2.2.1 Elaboração e aplicação do instrumento para a recolha dos dados .....44

2.2.3. Análise dos dados.................................................................. 51

CAPÍTULO 03 - RESULTADOS E DISCUSSÕES ..................................52

3.1. Concepções sobre história e filosofia da química no ensino...........................53

3.1.1. Relações com a sociedade ................................................... 53

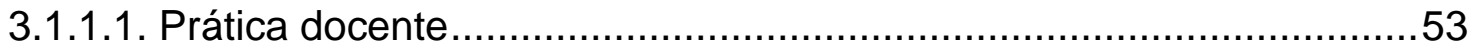

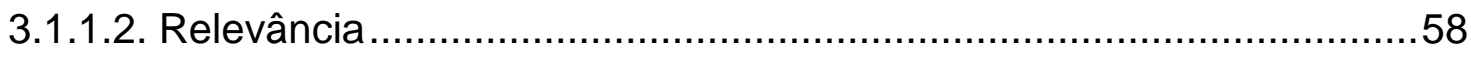

3.1.2. Modelos e modelagem ........................................................... 70

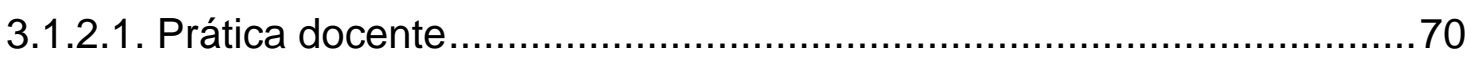

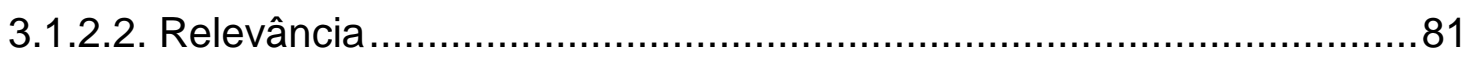




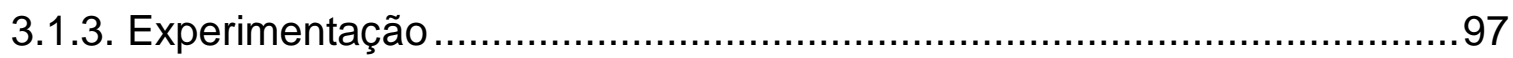

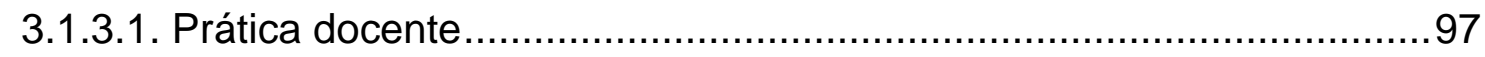

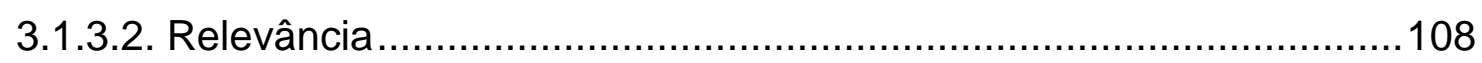

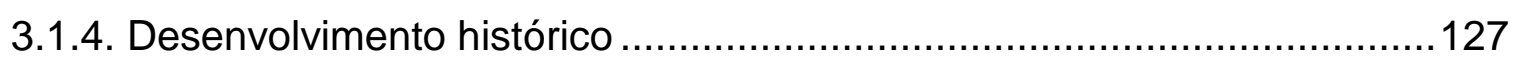

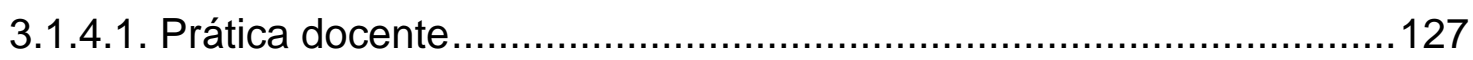

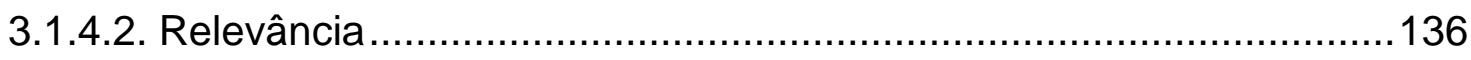

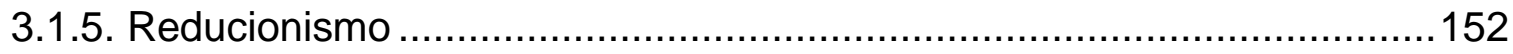

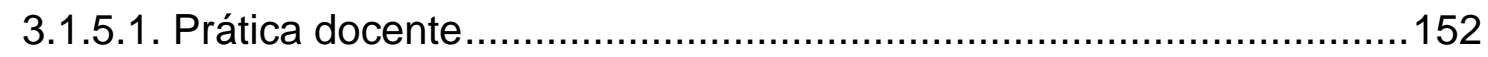

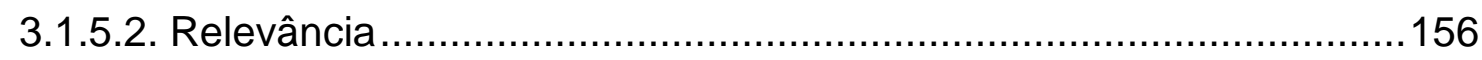

3.2. Fatores que afetam as concepções e práticas docentes ..............................168

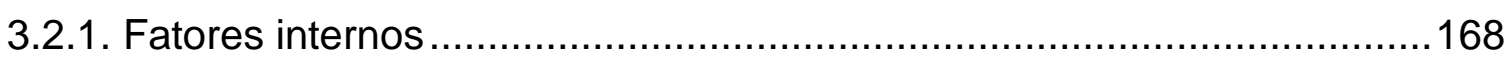

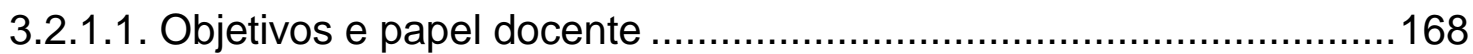

3.2.1.2. Conhecimentos do professor .....................................................183

3.2.1.3. Concepções sobre a disciplina de química..................................... 184

3.2.1.4. Concepções sobre ciência/cientistas............................................186

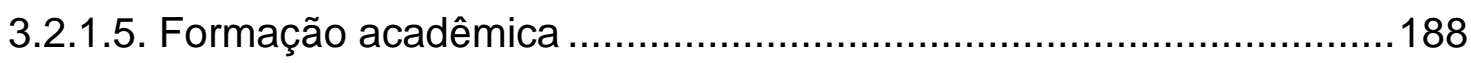

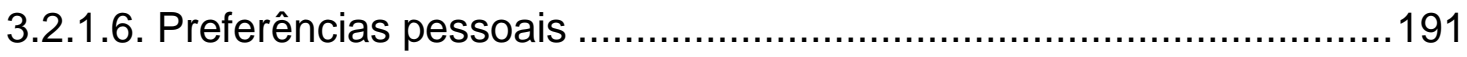

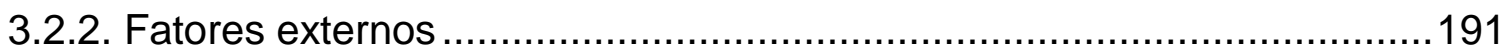

3.2.2.1. Dificuldades e desinteresse dos estudantes..................................191

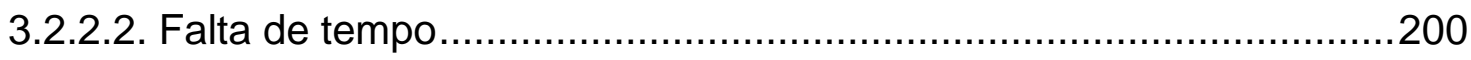

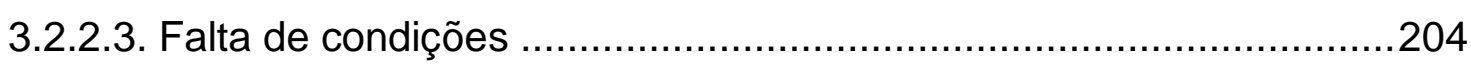

3.2.2.4. Demandas em relação ao ensino de química.................................205

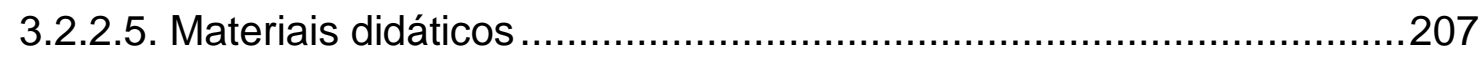

CAPÍTULO 04 - CONSIDERAÇÕES FINAIS ......................................216

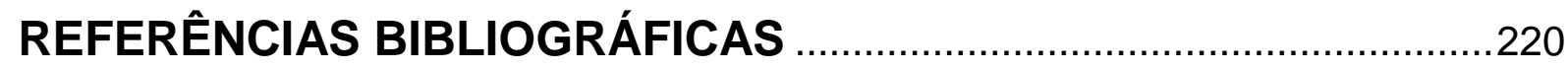

APÊNDICE A - Roteiro de entrevista .................................................232

APÊNDICE B - Quadro 10 - Temas utilizados para a elaboração do

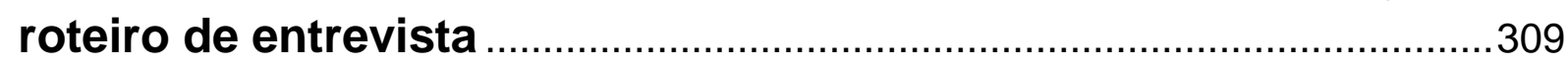

APÊNDICE C - Termo de consentimento livre e esclarecido ............315

ANEXO A - Normas de transcrição segundo Preti (1999) ..................316 


\section{INTRODUÇÃO}

Nas últimas décadas, após a consolidação da área de ensino de ciências como um corpo próprio de conhecimentos teóricos, inúmeras investigações têm sido desenvolvidas com o intuito de debater os caminhos pelos quais se pode promover a melhoria da educação científica. Dentre as perspectivas que buscam contribuir para esse desenvolvimento, destaca-se a história e filosofia da ciência (HFC).

Educadores têm apontado que a inclusão de considerações filosóficas, históricas e sociológicas acerca da ciência no ensino e nos cursos de formação docente pode, entre outros benefícios, tornar as aulas mais interessantes; promover uma visão mais adequada acerca da natureza da ciência e das inter-relações entre ciência, tecnologia e sociedade, bem como auxiliar os professores a organizar e comunicar suas concepções acerca da ciência (Adúriz-Bravo, 2001; Bastos, 1998; Matthews, 1995; Porto, 2010). Em certa medida, tais ideias influenciaram a elaboração de documentos curriculares oficiais em diversos países, os quais passaram a incluir, entre as principais finalidades da educação científica, a aprendizagem sobre a natureza da ciência.

Recentemente, o reconhecimento da complexidade e pluralidade do empreendimento científico tem originado propostas que apontam a necessidade do ensino sobre as ciências considerar as diferenças culturais, metodológicas e epistemológicas existentes entre as disciplinas científicas (Irzik e Nola, 2011). No que tange, particularmente, à educação em química, pesquisadores têm discutido o papel relevante da reflexão acerca dos métodos, valores, objetivos e produtos próprios dessa ciência, bem como sobre sua história e filosofia no aprimoramento do processo de ensino e aprendizagem (Erduran e Scerri, 2002; Erduran, 2007; Talanquer, 2013).

Apesar das recomendações em prol da utilização de elementos da HFC na educação científica, pesquisas têm constatado que, nas aulas de ciências, pouco ou nada se discute a respeito da ciência e do seu papel na sociedade (Höttecke e Silva, 2011; Martins, 2007; Erduran, 2001).

Diante de tais questões, a presente dissertação tem como principal objetivo investigar a concepção de professores de química sobre a inclusão de elementos da 
HFC no ensino, com foco nas características inerente às práticas e aos conhecimentos químicos.

De modo geral, pesquisadores têm apontado a influência de crenças, atitudes, valores e concepções docentes nas práticas pedagógicas e, consequentemente, na implementação de propostas educacionais (Mellado, 2011; Tardif, 2002; Wallace, 2014). Assim, caracterizar e compreender de que maneira os professores concebem a inclusão de aspectos filosóficos, históricos e sociológicos sobre a ciência na sua prática pode contribuir para o avanço dos debates acerca dos obstáculos à inclusão de elementos da HFC no ensino e para o desenvolvimento de projetos de formação, os quais possam motivar e preparar os docentes para discussões dessa natureza.

Visando atingir o objetivo proposto, foram entrevistados cinco docentes de química que atuam na rede pública de ensino do Estado de São Paulo. Essa opção foi feita, principalmente, com base na ideia de que, nas instituições de ensino públicas, os docentes teriam mais liberdade para inserir elementos da HFC do que nas escolas privadas, mais voltadas à aprovação dos estudantes nos exames vestibulares. Como referencial teórico, além da literatura sobre as relações entre a HFC e educação científica, utilizou-se também estudos que abordam as implicações da filosofia da química para o ensino.

O presente trabalho está estruturado em quatro capítulos. O Capítulo 1 trata dos referenciais teóricos que orientaram a pesquisa, apresentando as discussões e controvérsias concernentes à inclusão da HFC no ensino de ciências; as implicações da filosofia da química para o ensino de química; o papel das discussões históricas e filosóficas na formação inicial e continuada dos professores; as dificuldades, evidenciadas pela literatura, para a utilização da HFC na educação científica, assim como a importância do estudo das concepções docentes.

No Capítulo 2, concernente aos objetivos da pesquisa e à metodologia empregada, são apresentadas as características dos professores entrevistados, bem como as justificativas para a escolha dos sujeitos da pesquisa e do instrumento de recolha de dados. Ademais, é descrito o processo de elaboração do roteiro de perguntas que orientou as entrevistas com os docentes.

No Capítulo 3, são apresentados os resultados e discussões, considerando os temas, elaborados com base nas pesquisas em educação científica e nas 
diretrizes curriculares oficiais, e os subeixos temáticos, propostos ao longo do processo de análise dos dados.

Finalmente, no Capítulo 4, são feitas considerações gerais acerca dos resultados obtidos, evidenciando-se algumas implicações para a formação de professores e questões para futuras investigações. 


\section{CAPÍTULO 1 - REFERENCIAIS TEÓRICOS}

\subsection{A educação científica e a história e filosofia da ciência (HFC)}

O propósito de incluir discussões provenientes da história, filosofia e sociologia da ciência na educação científica não é recente. Desde o início do século $\mathrm{XX}$, argumentos em prol do ensino sobre as ciências podem ser encontrados em pronunciamentos de cientistas, programas de ensino, relatórios e livros (Matthews, 1995; McComas, Almazroa \& Clough, 1998).

Nas últimas décadas, com a emergência da área de ensino de ciências como um corpo próprio de conhecimentos teóricos sobre o ensino e aprendizagem das ciências naturais, as relações entre história e filosofia da ciência e a educação científica se tornaram mais profundas e abrangentes (Matthews,1998; Cachapuz et al., 2005). Consequentemente, têm surgido cada vez mais trabalhos que apontam a importância de discussões envolvendo aspectos históricos, filosóficos, sociológicos e éticos da ciência na formação de estudantes e professores.

Com base na ideia de que, por vezes, as concepções intuitivas dos estudantes - as quais podem dificultar o aprendizado de certos conceitos coincidem com noções científicas abandonadas ao longo da história, Martins (1990) considera que o conhecimento da evolução e das discussões envolvendo os resultados científicos aceitos atualmente poderia facilitar a compreensão de determinados temas no ensino de ciências. No que tange a esse aspecto, Galili e Hazan (2000), em uma investigação realizada com estudantes israelenses do ensino médio, apontaram que a inclusão de discussões históricas em um curso de óptica experimental favoreceu a compreensão dos conceitos científicos de visão, natureza da luz e imagem óptica. Assim, os pesquisadores concluíram que a abordagem de aspectos históricos poderia ser importante também em outros assuntos, nos quais haveria correspondência entre os modelos construídos historicamente e o conhecimento prévio dos alunos.

Apesar da importância atribuída à história da ciência para uma compreensão maior dos conteúdos científicos, a ideia de que isso possa ocorrer em decorrência de um suposto paralelismo entre as representações dos estudantes e as 
concepções científicas do passado é vista com cautela por muitos pesquisadores. Gagliardi (1988), por exemplo, aponta que as concepções dos estudantes atualmente são influenciadas por uma sociedade totalmente diferente daquela na qual determinados conhecimentos foram produzidos. Ainda assim, ele defende que conhecer os obstáculos ao desenvolvimento de certos conceitos científicos pode contribuir para lidar com as dificuldades dos estudantes em compreendê-los.

Porto (2010), tendo como referência os objetivos atuais da educação científica, considera que a abordagem adequada da história da ciência no ensino contribui para a superação de concepções equivocadas sobre a ciência e o seu desenvolvimento, bem como promove a compreensão acerca da construção dos conhecimentos científicos.

Para Matthews (1995), as aulas com elementos de história, filosofia e sociologia da ciência podem humanizar as ciências, aproximando-as dos interesses éticos, culturais e políticos da comunidade. Tal perspectiva é corroborada por Kolstø (2008), que considera como um estudo de caso envolvendo as discordâncias entre Millikan e Ehrenhaft sobre o elétron pode favorecer a educação científica para a cidadania. $\mathrm{O}$ autor defende que o conhecimento de alguns aspectos sobre ciência, evidenciados pelo episódio histórico analisado - a ciência como construção humana, a dependência mútua entre observação e teoria, a incerteza envolvida nas medidas e resultados experimentais e a importância da argumentação na ciência - contribui para uma participação mais crítica e responsável em questões de ciência e tecnologia que afetam a sociedade.

Solbes e Traver (2003) defendem que o entendimento da construção do conhecimento científico e dos contextos a partir dos quais as teorias emergem promove o desenvolvimento de concepções mais apropriadas sobre a ciência e o trabalho dos cientistas e, consequentemente, contribui para aumentar o interesse pela ciência e seu estudo.

Em certa medida, os estudos indicando os benefícios de se abordar com os estudantes questões como o que é ciência, de que modo ela funciona, quais suas características e relações com a sociedade, influenciaram a elaboração dos documentos curriculares oficiais de diversos países, os quais passaram a incluir a aprendizagem sobre ciências entre as principais finalidades da educação científica (McComas e Olson, 1998). No Brasil, por exemplo, os Parâmetros Curriculares Nacionais para o Ensino Médio (PCNEM) consideram que o ensino de ciências deve 
promover a compreensão dos conhecimentos científicos, do seu processo de construção e de suas implicações ambientais, sociais, políticas e econômicas (Brasil, 1999).

De certo modo, essa concepção se coaduna com a ideia de alfabetização científica, conceito usado por muitos educadores para reunir os principais objetivos da educação científica (Cachapuz et al. 2005). Sasseron e Carvalho (2011) apontam que, apesar da pluralidade semântica envolvendo o termo e das diferentes compreensões acerca das habilidades a serem desenvolvidas para se alfabetizar cientificamente os estudantes, é possível considerar que essa tarefa envolve:

- a compreensão básica de termos, conhecimentos e conceitos científicos fundamentais;

- o entendimento da natureza das ciências e dos fatores éticos e políticos que circundam sua prática; e

- a apreensão das relações existentes entre ciência, tecnologia, sociedade e meio ambiente.

Desse modo, a compreensão sobre a ciência, o seu desenvolvimento e as suas relações com a sociedade estão incluídas entre os principais objetivos da educação científica contemporânea. Em vista disso, é fundamental que o ensino de ciências abranja não apenas a aprendizagem dos conhecimentos científicos, mas também os aspectos filosóficos, históricos e sociais relativos ao empreendimento científico. Assim, cabe questionar quais questões sobre a ciência podem contribuir para se promover a alfabetização científica.

\subsection{Natureza da ciência e a história e filosofia da ciência (HFC)}

Os diversos estudos que discutem as implicações de aspectos filosóficos, históricos e sociológicos da ciência para a educação científica costumam utilizar as expressões "natureza da ciência" e "história e filosofia da ciência" (HFC). Desse modo, uma breve consideração sobre os significados que tais termos assumem nas pesquisas, e quais suas relações, pode contribuir para uma compreensão mais precisa dos assuntos, práticas e objetivos educacionais subjacentes às propostas 
que defendem a inclusão de aspectos da natureza da ciência e da HFC no ensino de ciências e na formação docente.

\subsubsection{História e filosofia da ciência}

Para Martins (2007; 2012), embora a história da ciência e a filosofia da ciência sejam áreas distintas, ao se abordar as contribuições de ambas para o ensino de ciências, os pesquisadores costumam utilizar o termo história e filosofia da ciência (HFC), devido às inter-relações entre os conhecimentos oriundos dessas disciplinas. Assim, Martins apresenta tal expressão tanto como um campo amplo de investigações próprias quanto uma área do conhecimento com profundas implicações para a educação científica.

McComas, Clough e Almazroa (1998) mencionam que a expressão história e filosofia da ciência (HFC) tem sido empregada para se referir à interação entre as diferentes disciplinas que fornecem informações sobre as características da ciência para a educação científica. No entanto, os autores defendem que natureza da ciência é um termo mais abrangente para descrever a atividade científica no âmbito da educação em ciências.

\subsubsection{Natureza da ciência}

No decorrer do tempo, a compreensão predominante sobre o termo natureza da ciência variou de acordo com as mudanças na própria concepção de ciência (Abd-El-Khalick \& Lederman, 2000; Lederman, 2007). Além disso, visto que historiadores, filósofos, sociólogos da ciência, cientistas e outros estudiosos têm ideias distintas sobre as várias ciências, não há uma definição específica, precisa e consensual dessa expressão.

Abd-El-Khalick, Bell e Lederman (1998) apontam que, normalmente, natureza da ciência é uma expressão utilizada para se referir à epistemologia da ciência, à ciência como forma de conhecimento, ou às crenças e valores associados à ciência e ao seu desenvolvimento. McComas, Clough e Almazroa (1998), por sua vez, definem o termo como uma arena híbrida e complexa que integra conhecimentos de diversos estudos sociais sobre as ciências com pesquisas das ciências cognitivas, em uma fecunda descrição sobre o que é ciência, como ela funciona, de que modo 
os cientistas atuam e como a sociedade influencia os empreendimentos científicos e reage a eles. Esses autores também consideram que, para os educadores, a expressão natureza da ciência é utilizada especificamente para descrever temas da história, filosofia, sociologia e psicologia da ciência que podem contribuir com o processo de ensino e aprendizagem em ciências. Para Adúriz-Bravo (2001), a natureza da ciência é uma linha de investigação da HFC. O autor associa esses termos à epistemologia que, segundo ele, é a disciplina específica que incorpora elementos da história, filosofia e sociologia da ciência, inclui a metodologia das ciências, e cujo objeto de estudo é a ciência em geral e cada uma das ciências em particular.

Outro modo pelo qual alguns pesquisadores buscam definir a natureza da ciência é por meio de uma série de aspectos que, segundo eles, fornecem uma rica e abrangente descrição da atividade científica.

\subsubsection{Natureza da ciência: aspectos consensuais na educação científica}

Inúmeras investigações têm sido feitas no sentido de identificar e descrever os pressupostos sobre a ciência que podem contribuir para que estudantes e professores compreendam a complexidade desse empreendimento e de seu desenvolvimento (McComas, Almazroa \& Clough, 1998; Osborne et al., 2003; Akerson et al., 2000; Lederman et al., 2002).

Alguns trabalhos apontam que, a despeito da falta de consenso sobre o que é ciência, há certa concordância, com base nas concepções epistemológicas predominantes atualmente, em torno de ideias distorcidas que devem ser superadas e de aspectos gerais a serem considerados nas aulas de ciências (Cachapuz et al., 2005, Osborne et al., 2003).

Cachapuz e colaboradores (2005), por exemplo, indicam a necessidade de se superar ideias elitistas, ateóricas, dogmáticas e empírico-indutivistas sobre a ciência, que se disseminaram em decorrência de um ensino pautado na transmissão de conteúdos. Segundo os autores, "visões deformadas da ciência e da tecnologia" como a ideia de que o conhecimento científico é verdadeiro, comprovado por meio de uma sequência rígida de passos, a qual culmina na elaboração das leis e teorias - podem levar ao desinteresse dos estudantes pela ciência e seu estudo. 
Além disso, alguns autores têm procurado estabelecer temas consensuais sobre a natureza da ciência relevantes para o ensino de ciências, mediante a análise da literatura em ensino de ciências, de estudos filosóficos sobre a ciência e de propostas curriculares.

McComas e Olson (1998), tomando por base a análise de oito documentos curriculares $^{1}$, concluíram que há um considerável consenso em torno de quais aspectos da natureza da ciência devem ser abordados na educação científica. Tais aspectos foram sumarizados por McComas, Almazroa e Clough (1998, p. 513), na lista a seguir.

- O conhecimento científico, embora durável, possui caráter tentativo.

- O conhecimento científico baseia-se, em grande medida, mas não completamente, em observações, evidências experimentais, argumentos racionais e ceticismo.

- Não há um único modo para fazer ciência (logo, não há um método científico universal com etapas definidas).

- Ciência é uma tentativa de explicar fenômenos naturais.

- Leis e teorias têm diferentes papéis na ciência; logo, estudantes devem notar que as teorias não se tornam leis, mesmo com evidências adicionais.

- Pessoas de todas as culturas contribuem para a ciência.

- Um novo conhecimento deve ser comunicado de modo claro e aberto.

- Os cientistas necessitam manter registros precisos, revisões por pares e replicabilidade de seus experimentos.

- Observações dependem de teorias prévias.

- Cientistas são criativos.

- A história da ciência revela um caráter evolucionário e um revolucionário.

- Ciência é parte das tradições sociais e culturais.

- Ciência e tecnologia se impactam mutuamente.

- As ideias científicas são afetadas pelas esferas histórica e social.

\footnotetext{
${ }^{1}$ EUA, Benchmarks for Science Literacy (AAAS, 1993); EUA, Science Framework for California Public Schools (California Department of Education, 1990); EUA, National Science Education Standards (NRC, 1996); Austrália, A Statement on Science (Curriculum Corporation, 1994); EUA, The Liberal Art of Science (AAAS, 1990); Inglaterra/País de Gales, Science in the National Curriculum (Department of Education, 1995); Nova Zelândia, Science in the New Zealand Curriculum (Ministry of Education, 1993); e Canadá, Common Framework (Council of Ministers of Education, 1996).
} 
Lederman e colaboradores (2007), por sua vez, mediante a revisão de artigos sobre a natureza da ciência, apontam os seguintes elementos que, para eles, estão em um nível de generalidade apropriado para os estudantes da educação básica².

- O conhecimento científico é tentativo (sujeito a mudanças).

- O conhecimento científico tem base empírica (baseado em, ou derivado de observações do mundo natural).

- O conhecimento científico é subjetivo (envolve experiências prévias pessoais, vieses pessoais e depende de teorias).

- O conhecimento científico envolve necessariamente inferência humana, imaginação e criatividade (envolve a invenção de explicações).

- O conhecimento científico é imerso social e culturalmente.

- Existe distinção entre observação e inferência.

- As leis e teorias científicas têm funções características e mantêm relações entre si.

Osborne e colaboradores (2003) - considerando os dados obtidos de um estudo envolvendo especialistas em educação científica, cientistas, professores experientes, investigadores engajados em melhorar a compreensão pública da ciência, bem como historiadores, filósofos e sociólogos da ciência - sugerem a abordagem dos seguintes assuntos a respeito da natureza da ciência:

- Método científico e teste crítico de ideias e hipóteses.

- Criatividade.

- Desenvolvimento histórico do conhecimento científico.

- O papel dos questionamentos na ciência.

- Diversidade de meios e abordagens.

- Análise e interpretação de dados.

- Ciência e certeza.

- Hipótese e previsão.

- Cooperação e colaboração no desenvolvimento do conhecimento científico.

\footnotetext{
2 Os autores utilizam a expressão "K-12 students".
} 
Embora possuam tópicos semelhantes, estas listas também apresentam diferenças, as quais evidenciam a dificuldade e complexidade de se oferecer, mesmo no âmbito da educação científica, respostas consensuais a respeito de questões como: o que é ciência? Por meio de quais processos os conhecimentos científicos são obtidos, consolidados e modificados? Quais fatores influenciam a construção dos conhecimentos científicos? Quais são seus múltiplos impactos?

Além das dúvidas e discussões sobre a possibilidade de se descrever a ciência de modo inequívoco, outras questões relevantes dizem respeito aos limites e às possibilidades do estabelecimento de uma visão consensual sobre a natureza da ciência para a educação científica, bem como ao modo de se abordar esse assunto em sala de aula.

\subsubsection{Natureza da ciência e HFC: abordagens didáticas}

Vários estudos têm considerado os modos pelos quais se pode promover uma melhor compreensão da natureza da ciência em sala de aula. Forato e colaboradores (2011) consideram que as abordagens utilizadas podem ter enfoques diferentes - filosófico, histórico ou sociológico - de acordo com as questões que se pretende trabalhar e o perfil das respostas fornecidas. Segundo os pesquisadores, a abordagem baseada em uma resposta do tipo empírica tem como objetivo considerar o que é ciência a partir de estudos na área da história e da sociologia da ciência. Para isso, pode-se recorrer à análise de documentos históricos originais produzidos pelos cientistas, tomando-se por base o contexto social, econômico, político e cultural do período estudado. Caso a resposta seja do tipo normativa ou axiológica, a qual envolve o julgamento de valores, o foco é avaliar, mediante considerações filosóficas, o que é correto e errado na prática científica. Há também a abordagem analítica, baseada em questões filosóficas como: quais concepções de ciência já existiram? Quais se podem inventar? Forato e colaboradores (2011) consideram ainda que, embora as abordagens axiológica e analítica sejam fundamentais para as investigações, elas não abrangem a dimensão humana da ciência, a construção sócio-histórica do conhecimento e outras questões importantes sobre a natureza da ciência. Desse modo, de acordo com os pesquisadores, um dos aspectos centrais para o processo de ensino e aprendizagem de questões sobre a ciência é a consideração de episódios históricos, tendo como referência as 
recomendações da historiografia contemporânea, pois esses episódios "podem atribuir significado às noções epistemológicas abstratas" (Forato et al., 2011, p. 29). Nesse sentido, é importante que o estudo aprimore a concepção de ciência tomando-se como base a consideração dos seguintes aspectos: papel dos erros e das controvérsias; contribuição do debate entre diferentes teorias; diversidade de pensadores que trabalharam nas mesmas questões; e a influência de fatores sociais, políticos, econômicos e culturais no desenvolvimento do conhecimento científico.

Abd-El-Khalick (2013) aponta estudos que indicam a importância de se abordar a natureza da ciência de modo implícito, como parte da cultura da prática científica. De acordo com essa noção, a compreensão do funcionamento da ciência ocorreria como consequência natural da participação dos estudantes em diferentes situações didáticas nas quais eles tivessem contato com os processos de produção do conhecimento científico, tais como atividades investigativas que se aproximem da prática científica autêntica ou estudos sobre episódios históricos, sem que houvesse reflexões e discussões epistemológicas explícitas. No entanto, embora defenda as atividades de investigação científica e a HFC como contextos ideais para o ensino e a aprendizagem da natureza da ciência, o pesquisador aponta que o engajamento em tais atividades, por si só, não promove modificações nas ideias epistemológicas dos estudantes.

Assim, Abd-El-Khalick (2013) introduz a distinção entre "ensinar sobre a natureza da ciência" e "ensinar com a natureza da ciência", bem como mostra a importância de ambas as abordagens. "Ensinar sobre a natureza da ciência" é uma abordagem voltada para o ensino de imagens da ciência compatíveis com o seu desenvolvimento histórico, psicológico e sociológico, a qual contribui para que os estudantes compreendam a complexidade envolvida na geração e validação do conhecimento científico. Em relação a essa questão, Abd-El-Khalick (2013) defende que o melhor modo de promover a compreensão da natureza da ciência é a partir de um trabalho explícito-reflexivo, centrado nos alunos e de natureza colaborativa. Para o autor, qualquer trabalho didático que pretenda desenvolver concepções mais adequadas sobre a construção da ciência deve incluir explicitamente, entre os objetivos de aprendizagem, a compreensão acerca de aspectos específicos da natureza da ciência. Ademais, deve envolver a realização de atividades preparadas para permitir que os estudantes reflitam criticamente acerca de suas experiências de 
aprendizagem com base em questões epistemológicas, relacionadas ao desenvolvimento, à validação e às características do conhecimento científico. "Ensinar com a natureza da ciência", por sua vez, tem como foco a preparação de ambientes de aprendizagem, os quais envolvam aspectos importantes da prática científica autêntica e a realização de abordagens didáticas que compartilhem várias das características relacionadas às melhores práticas em ensino de ciências.

Assim, a busca por temas consensuais sobre a natureza da ciência, e a discussão sobre quais as abordagens mais adequadas para realizar essa tarefa, são importantes para contornar as dificuldades envolvidas na inserção de discussões sobre a atividade científica em sala de aula. Entretanto, devido à existência de diferentes ramos especializados das ciências, e à complexidade de cada um deles, outras questões importantes acerca da inclusão de elementos da HFC no ensino de ciências devem ser consideradas.

\subsubsection{As críticas à visão consensual acerca da natureza da ciência}

No que se refere à natureza do empreendimento científico, há muitas divergências sobre quais características poderiam representar, de modo preciso e adequado, a ciência em toda a sua complexidade e pluralidade, assim como sobre a possibilidade de se alcançar uma tal representação (McComas, Almazroa \& Clough, 1998; Alters, 1997; Eflin et al.,1999).

Ziman $(2000)^{3}$ (apud Osborne et al., 2003) comenta que, apesar de todos os esforços, os filósofos não foram bem-sucedidos em conceituar "ciência". Assim, a dificuldade em se definir, de maneira inequívoca, o que é ciência e como ela funciona, também torna complexa a discussão sobre quais aspectos da natureza da ciência devem ser ensinados aos estudantes e como realizar essa tarefa (Abd-ElKhalick \& Lederman, 2000).

Eflin e colaboradores (1999), filósofos da ciência, consideram que a noção de natureza da ciência pressupõe uma visão essencialista sobre a ciência, segundo a qual um conjunto de critérios é suficiente para descrever todas e apenas as atividades e investigações consideradas científicas. De acordo com eles, tal concepção se relaciona com as ideias de que: há uma natureza da ciência a ser

\footnotetext{
${ }^{3}$ ZIMAN, J. Real science: what it is and what it means. Cambridge: Cambridge University Press,
} 2000. 
descoberta e ensinada aos estudantes; existe uma lista de princípios capazes de descrever a natureza da ciência; e, para uma disciplina ser considerada científica, cada um desses princípios deve ser verdadeiro para essa disciplina. Entretanto, os autores apontam que, apesar de ser insustentável filosoficamente, tal concepção pode ser conveniente aos propósitos pedagógicos.

Em um trabalho recente, Matthews (2012) tece críticas à denominada "visão consensual", segundo a qual apenas aspectos menos controversos ou consensuais ${ }^{4}$ da natureza da ciência devem ser ensinados aos estudantes. Para o autor, que centra suas considerações no trabalho de Lederman (2007), embora forneça questões relevantes com base nas quais alunos e professores possam refletir e discutir sobre a atividade científica, a lista de características consensuais da natureza da ciência corre o risco de ser ensinada segundo uma visão dogmática e fechada a respeito da ciência.

Irzik e Nola (2011) consideram que a lista de aspectos da natureza da ciência simplifica sobremaneira um empreendimento dinâmico e complexo como a ciência. Segundo eles, a visão consensual não considera importantes assuntos sobre a prática e os objetivos da ciência; dá origem a questões sobre as quais não se aprofunda; abrange aspectos que não são compartilhados pelas diferentes ciências e alguns outros que, embora comuns a elas, não são suficientes para definir o que é ciência e nem para diferenciá-la de outras atividades humanas. Ademais, Irzik e Nola (2011) compreendem que o conjunto de tópicos consensuais sobre a natureza da ciência implica uma unicidade que não é própria da ciência, visto que as inúmeras disciplinas consideradas científicas possuem características distintas umas das outras e - mesmo em aspectos semelhantes - cada uma delas apresenta peculiaridades em seus objetivos, valores, produtos, bem como em suas práticas e metodologias, que as tornam únicas. Como exemplo, Irzik e Nola (2011) apontam que as habilidades envolvidas na observação de planetas e estrelas usando um telescópio são bem diferentes daquelas necessárias para se reconhecer um fóssil.

Com base nas discussões desenvolvidas nesses trabalhos, destaca-se não apenas a dificuldade em se obter um conjunto de aspectos que possa fornecer uma ideia suficientemente abrangente acerca da ciência e da complexidade envolvida em sua construção, mas também, e principalmente, a dificuldade de se discutir questões

\footnotetext{
${ }^{4}$ Para uma discussão mais detalhada a respeito desse assunto, vide Eflin e colaboradores (1999).
} 
sobre a ciência na escola a partir de uma lista de características que, supostamente, seriam suficientes para considerar determinado empreendimento como científico.

Em anuência com Matthews (2012), salienta-se a preocupação com a possibilidade de uma lista de aspectos consensuais ser utilizada de modo dogmático, visto que uma das principais finalidades atribuídas ao uso da HFC no ensino de ciências é o desenvolvimento da capacidade crítica. Se o que se pretende é um ensino sobre ciências que contribua para alfabetização científica dos estudantes, em uma sociedade cada vez mais afetada pelos múltiplos impactos do desenvolvimento científico e tecnológico, é necessária uma abordagem mais reflexiva e abrangente do que o mero apontamento de afirmações acerca da ciência. Para isso, é preciso estimular os estudantes a exercitar seu pensamento crítico a respeito de temas ou tópicos que tenham o potencial de gerar reflexões e discussões prolíficas sobre diversas questões relacionadas à construção da ciência.

Além disso, conforme evidenciam Irzik e Nola (2011), tomar por base a visão consensual no ensino sobre ciência pode disseminar uma visão monolítica de ciência que desconsidera as peculiaridades das diferentes disciplinas científicas. Nesse sentido, entende-se que a aprendizagem sobre uma determinada ciência envolve a compreensão de seus métodos, valores, objetivos e produtos, bem como a participação em atividades investigativas que se aproximem da prática autêntica dessa ciência.

\subsection{A abordagem de aspectos da natureza da química}

A inclusão de aspectos filosóficos, históricos e sociológicos inerentes à ciência e ao seu desenvolvimento também é recomendada para o ensino de química voltado à formação para a cidadania. Nos documentos curriculares oficiais da educação brasileira, por exemplo, a química

[...] pode ser um instrumento de formação humana que amplia os horizontes culturais e a autonomia no exercício da cidadania, se o conhecimento químico for promovido como um dos meios de interpretar o mundo e intervir na realidade, se for apresentado como ciência, com seus conceitos, métodos e linguagens próprios, e como construção histórica, relacionada ao desenvolvimento tecnológico e aos muitos aspectos da vida em sociedade. (Brasil, 2002, p. 87). 
Ademais, o documento Orientações Curriculares para o Ensino Médio (Brasil, 2006) considera a importância de se compreender o conhecimento químico como uma construção histórica e social e, portanto, coloca como núcleo básico do ensino de química conhecimentos, habilidades e valores relacionados à história, à filosofia da química e a suas relações com a sociedade e o ambiente. ${ }^{5}$

Erduran e Scerri (2002) defendem a ideia de que a inclusão de abordagens filosóficas na educação química pode melhorar o processo de ensino e aprendizagem dessa ciência. Segundo eles, um dos motivos pelo qual a inclusão de elementos da HFC na educação científica tem sido mínima é a falta de atenção dos educadores aos domínios específicos das ciências.

Além das discussões sobre assuntos da natureza da química, alguns estudos defendem a importância da participação dos estudantes em atividades investigativas que promovam conhecimentos, habilidades e competências associadas ao domínio específico da química.

Erduran (2007), à luz de discussões oriundas do campo da psicologia cognitiva acerca da fundamentação científica, tece algumas considerações sobre os conhecimentos declarativos (i.e., "saber que") - os quais podem ser descritos ou relatados de algum modo - e os conhecimentos procedimentais (i.e., "saber como") - os quais se manifestam na prática. A pesquisadora explica que certos conhecimentos científicos procedimentais, tais como saber ler um gráfico, são de domínio geral; enquanto outros, como saber fazer uma titulação em química, são de domínio específico. Além disso, aponta que o desenvolvimento de competências nas diversas áreas científicas depende do acúmulo gradual de habilidades e conhecimentos. Outra questão relevante, abordada por Erduran (2007), é que, enquanto determinadas habilidades são específicas para uma área, outras são gerais para certos campos, e algumas ainda são gerais para todos os domínios científicos. Desse modo, a autora defende a participação dos alunos em ambientes de aprendizagem nos quais possam desenvolver, avaliar e revisar conhecimentos químicos, o que, em certa medida, faz com que eles se aproximem do trabalho dos químicos.

\footnotetext{
${ }^{5} \mathrm{Em}$ um dos quadros nos quais são apresentados os conhecimentos químicos da Base Comum Nacional, o documento Orientações Curriculares para o Ensino Médio (OCEM) faz uso da expressão "filosofia da química". Apesar disso, e de apontar a importância da abordagem de aspectos específicos da química, o documento não tem como referências estudos oriundos da recente área da filosofia da química.
} 
Tendo em vista tais questões, pode-se considerar que as habilidades e competências a serem desenvolvidas pelos estudantes na disciplina de química não se desvinculam da aprendizagem dos modelos, leis e teorias, visto que tanto os procedimentos quanto os conhecimentos da química e sobre a química se desenvolveram em uma relação de dependência recíproca. Assim, torna-se evidente a importância da inclusão de elementos da história e filosofia da ciência específicos da química para a formação dos estudantes, por meio de situações e ambientes de aprendizagem baseados na investigação química, e de discussões explícitas sobre a natureza desse conhecimento.

A filosofia da química, nesse sentido, por ser uma das áreas que buscam a compreensão a respeito da construção do conhecimento químico, de como os químicos atuam e das relações entre a química e a sociedade, pode contribuir para reflexões fundamentais no processo de ensino e aprendizagem dessa disciplina.

\subsubsection{A filosofia da química e o ensino de química}

A despeito de sua produtividade e popularidade, a química, antes dos anos 1990, pouco inspirava os filósofos das ciências a realizarem seus estudos. Até então, apesar de haver trabalhos abordando questões filosóficas relacionadas a essa ciência e ao seu desenvolvimento como disciplina científica, a filosofia das ciências tradicional centrava-se na física e eram poucos os estudiosos em ensino de química, historiadores da química e químicos que refletiam acerca dos conceitos e metodologias da química (Labarca et al., 2013; Bensaude-Vincent, 2009; Schummer, 2011).

Entretanto, desde o fim dos anos 1990, a filosofia da química se estabeleceu como um campo de investigação autônomo, reunindo químicos, filósofos e historiadores que atualmente produzem uma grande quantidade de estudos. Os pesquisadores dessa subdisciplina têm analisado, dentre outras questões, as perspectivas, outrora esquecidas, de filósofos clássicos sobre a química; debatido a questão da redução da química à física; estudado a metodologia química à luz de conceitos filosóficos clássicos sobre as ciências; e investigado os conceitos, os métodos e as teorias fundamentais da química moderna (Schummer, 2011). Desse modo, a filosofia da química, por fornecer prolíficos estudos a respeito da natureza 
do conhecimento químico, pode orientar o ensino de química (Erduran e Scerri, 2002; Scerri, 2007; Labarca et al., 2013; Lemes, 2013).

\subsubsection{A natureza da química e a educação química}

Atualmente, tomando como base discussões oriundas da área de filosofia da química, diversos estudos em educação têm abordado como o trabalho pedagógico com aspectos específicos da ciência química pode contribuir para aprimorar 0 processo de ensino e aprendizagem de química.

Uma das principais características da química com implicações para o ensino concerne à natureza dos modelos e ao uso da modelagem. Justi (2010) considera que os modelos científicos são, ao mesmo tempo, as principais ferramentas utilizadas para gerar conhecimento e os principais produtos da ciência. Especificamente com relação à química, Justi (2010) aponta os modelos como ferramentas que permitem desenvolver, avaliar e revisar os conhecimentos produzidos. Para Labarca e colaboradores (2013), na química a construção de modelos não é útil somente para a compreensão dos fenômenos estudados, mas também para orientar futuras investigações. Talanquer (2013) enfatiza ainda que, devido à natureza tecnocientífica da química, os modelos químicos são empregados para controlar e transformar o ambiente ao nosso redor.

A reflexão sobre o papel dos modelos e o processo de modelagem está associada com questões epistemológicas e ontológicas subjacentes às relações entre os níveis macroscópicos e microscópicos. Para Erduran, Adúriz-Bravo e Naaman (2007) essas relações podem ser mais bem compreendidas com base nas discussões sobre a questão da superveniência. Embora reconheçam que tal noção ainda é objeto de discordâncias entre os estudiosos, Erduran e colaboradores consideram-na como uma relação de dependência assimétrica e a explicam do seguinte modo: dois sistemas macroscópicos, constituídos pelos mesmos componentes microscópicos, apresentarão as mesmas propriedades macroscópicas; por outro lado, sistemas macroscópicos que apresentam as mesmas propriedades macroscópicas não necessariamente são compostos por componentes microscópicos idênticos. A utilização de modelos na química suscita também discussões acerca da realidade ou não dos objetos representados por esses 
modelos, bem como sobre a possibilidade de os modelos descreverem fielmente 0 mundo (Chamizo, 2013; Rozentalski, 2013).

Desse modo, conforme aponta Erduran (2001), "os modelos e a modelagem (...) fornecem um contexto crucial e relevante por meio do qual aspectos epistemológicos da química podem ser promovidos em sala de aula" (p. 584). Consequentemente, torna-se fundamental que, nas aulas de química, os estudantes desenvolvam e comuniquem seus próprios modelos; discutam as limitações, abrangências e especificidades deles, utilizando-os para explicar os fenômenos estudados; e se envolvam em discussões sobre a complexidade da elaboração dos modelos e os motivos pelos quais eles são utilizados na química (Justi, 2010; Erduran, 2001; Lemes, 2013).

Outra discussão relevante da filosofia da química para o ensino se refere às características específicas da prática química. A experimentação é um aspecto central da química e - diferente do que ocorre na física, na qual o teste de teorias ganha destaque ao se discutir o papel dos experimentos - serve, de modo geral, para analisar e sintetizar novas substâncias, enquanto as teorias funcionam como guia para as sínteses e a identificação dos materiais (Schummer, 2004). Ademais, os resultados experimentais em química foram e ainda são influenciados, em grande medida, pelo desenvolvimento tecnológico da instrumentação, o qual não apenas facilitou o acesso aos fenômenos inacessíveis diretamente pela percepção humana, como também influenciou as próprias noções ontológicas a respeito das entidades estudadas (Chamizo, 2014; Schummer, 2002).

Com relação ao ensino de química, tais considerações apontam para a importância da preparação de atividades pedagógicas, nas quais os estudantes compreendam o funcionamento da química e o trabalho dos químicos (Erduran, 2007). Nessa perspectiva, é importante que os experimentos não sejam apresentados de forma estanque, sem estabelecer relações com outras atividades (discussão, escrita, exposição, etc.). Ao contrário, devem fazer parte de um conjunto concertado de atividades, por meio das quais os estudantes possam: observar; organizar dados; levantar hipóteses; elaborar seus próprios modelos com base nos seus conhecimentos prévios; testar, avaliar e discutir ideias, bem como comunicá-las aos colegas. Portanto, as observações e resultados experimentais devem ser relacionados coerentemente com os conceitos e modelos elaborados pela química (Lemes, 2013; Schumacher \& Reiners, 2013; Silva et al., 2010). Além disso, é 
importante que o estudante tenha a oportunidade de refletir a respeito das atividades realizadas, não apenas em relação a aspectos gerais da ciência, mas, principalmente, sobre características peculiares da química, tais como a síntese como um objetivo da experimentação, a ética na experimentação, a relação simbiótica da química com a tecnologia, e o papel da instrumentação na atividade química (Schumacher \& Reiners, 2013).

Outro tema que também suscita reflexões importantes para a educação química é a concepção reducionista da química em relação à física, a qual é considerada como uma das principais causas para o pouco desenvolvimento da filosofia da química antes dos anos 1990 (Labarca et al., 2013).

Labarca e colaboradores (2013) apontam dois tipos de reducionismo, o ontológico e o epistemológico. Segundo os autores, a redução ontológica considera que há apenas um nível de realidade possível, o fundamental, enquanto os outros níveis têm apenas uma existência subjetiva e aparente. De acordo com essa visão, a física, como ciência fundamental, representaria a realidade tal como ela é, enquanto a química seria apenas uma disciplina fenomenológica que descreve a realidade, não como realmente é, mas como se apresenta na aparência. A redução epistemológica, por sua vez, defende que uma teoria poderia ser redutível à outra, caso pudesse também ser deduzida desta. Segundo tal concepção, os conhecimentos químicos poderiam ser deduzidos a partir das leis e princípios da física.

Embora venha sofrendo diversas críticas, principalmente, a partir da consolidação da filosofia da química como disciplina, a perspectiva reducionista influenciou sobremaneira a educação química. Para Talanquer (2013), a concepção de química como uma disciplina subalterna à física reforça a ideia de que apenas teorias e modelos químicos expressos em termos físico-matemáticos possuem valor. Consequentemente, dentre outros efeitos, os modelos quantitativos e algoritmos, mais característicos da física, têm sido mais valorizados no ensino de química para resolver problemas exemplares e construir explicações, em detrimento dos aspectos qualitativos, típicos do conhecimento químico.

Assim, Erduran e Scerri (2002) defendem que a inclusão do tema reducionismo no ensino de química pode contribuir para a compreensão de características específicas da química e de conceitos químicos importantes, tais 
como: ligação química, estrutura molecular e composição química, além de favorecer a argumentação durante as atividades realizadas.

Ainda sobre os impactos da visão reducionista sobre a educação em química, Talanquer (2013) aponta que tal noção desconsidera a essência tecnológica da química, importante para o entendimento de suas relações com a indústria, o comércio e a sociedade.

Um dos aspectos mais característicos da atividade química é o seu pronunciado caráter tecnológico. Schummer (1999) considera que os conceitos utilizados para diferenciar tecnologia de ciência falham quando aplicados à química. Para Sjöström (2007), isso ocorre porque os químicos não têm como objetivo apenas explicar e compreender o mundo, mas pretendem, também, modificá-lo. Mais especificamente:

(...) os químicos se esforçam para compreender a Natureza, transformando-a; seus objetivos centrais não são apenas descrever, explicar e prever as propriedades e os comportamentos das substâncias químicas, mas também transformá-las e criar novas entidades químicas com aplicações potenciais (Talanquer, 2013, p.1759).

A natureza tecnocientífica da química também se revela nas relações mútuas que ela estabelece com a indústria, as quais conferem à química um caráter diferenciado das outras ciências, e influenciam a sua imagem perante a sociedade. Em decorrência de sua natureza híbrida - tecnológica e científica - a química apresenta dimensões sociais, éticas, políticas e econômicas que a distinguem das outras ciências, e que podem suscitar reflexões fundamentais na educação química a respeito das relações entre ciência e sociedade.

Talanquer (2013) considera que tanto o currículo quanto as práticas educacionais devem considerar os modos característicos de pensar e fazer química, os quais foram muito influenciados por sua natureza tecnocientífica. Com base nessa perspectiva, o autor defende a necessidade de o ensino de química ter como objetivo não apenas que os estudantes compreendam e expliquem os fenômenos químicos estudados, mas desenvolvam as habilidades e adquiram os conhecimentos necessários para entender como a química contribuiu para pensar e transformar o mundo. Ademais, Talanquer (2013) considera importante que os alunos reconheçam 
e avaliem os impactos políticos, econômicos, ambientais e sociais decorrentes da produção e do consumo dos produtos tecnológicos da química.

De acordo com Sjöström e Talanquer (2014), no ensino de química tradicional, caracterizado pela ênfase nos modelos e conceitos científicos, há pouco espaço para a consideração de assuntos CTSA (Ciência, Tecnologia, Sociedade e Ambiente) associados com a prática química. Assim, os pesquisadores defendem uma perspectiva humanística de educação química, que integre conhecimentos químicos e componentes sociais, bem como promova a compreensão dos estudantes acerca de como as ideias químicas podem ser utilizadas para refletir acerca de problemas sociais e ambientais.

Tendo em vista tais considerações, é fundamental que os estudantes tenham a oportunidade de participar de atividades de investigação e projetos tecnológicos, nos quais possam resolver diferentes tipos de questões e usar ferramentas práticas e intelectuais. Além disso, é importante que reflitam criticamente sobre as implicações do desenvolvimento da química na sociedade.

A discussão a respeito da natureza do conhecimento químico envolve também, em grande medida, a história da química, pois é por seu intermédio que se pode perscrutar os meandros percorridos pela química, compreender os fatores externos e internos que influenciaram seu desenvolvimento e analisar suas particularidades. Segundo Schummer (2011), a consideração das teorias e dos conceitos e métodos próprios da química exige não apenas competências em química e filosofia, mas uma compreensão profunda da história da química, visto que as disciplinas científicas, com suas características, são um retrato atual de um processo de desenvolvimento histórico.

Assim, é importante que a educação química inclua discussões históricas que permitam aos alunos a compreensão sobre a natureza da ciência e da química. Para isso, pode-se utilizar estudos de caso, experimentos históricos e outras atividades que evidenciem, dentre outros aspectos, a natureza criativa, provisória e inferencial do conhecimento científico; as relações entre a química, a indústria e sociedade; o papel dos instrumentos no desenvolvimento da química e a importância das classificações e dos aspectos qualitativos na química (Erduran, 2007; Tolvanen et al., 2013; Porto, 2010). 
Diante dos potenciais benefícios provenientes da utilização de elementos da HFC no ensino, torna-se necessária a inclusão de discussões históricas e filosóficas na formação inicial e continuada dos professores.

De modo geral, a reflexão sobre a natureza do conhecimento científico ajuda os docentes a "explicitar, comunicar e estruturar suas ideias acerca da natureza da ciência e, consequentemente, pode levar à melhoria de seu desempenho profissional" (Adúriz-Bravo, 2001, p. 81). Ademais, promove uma compreensão mais adequada, profunda e abrangente sobre: o empreendimento científico (Fernandez et al., 2002); as terminologias científicas; os objetivos das disciplinas; o conteúdo a ser ministrado (Matthews, 1995), assim como a respeito das inúmeras questões envolvidas na educação científica (Villani, 2001).

Considerando, mais especificamente, as contribuições das discussões realizadas no campo da história e da filosofia da química para a educação química, torna-se evidente a importância da consideração de aspectos particulares da química na formação docente.

Segundo Scerri (2007), a reflexão acerca dos aspectos filosóficos subjacentes às explicações químicas pode ajudar os professores a fornecerem melhores explicações e encontrarem diferentes modos de esclarecer os conteúdos químicos, de acordo com as características de seus estudantes. Scerri (2007) entende que o exame profundo das teorias, leis e modelos químicos, bem como das diferenças e semelhanças entre as disciplinas científicas, pode aumentar a eficácia do ensino e provocar o interesse dos docentes em questões sobre a natureza da química.

Erduran, Adúriz-Bravo e Naaman (2007) explicam que a reflexão e o estudo de temas relevantes provenientes da filosofia da química favorecem 0 desenvolvimento do conhecimento dos conteúdos e do conhecimento pedagógico dos conteúdos ${ }^{6}$, ou seja, a consideração de questões filosóficas sobre a química pode auxiliar os professores a compreenderem de modo mais aprofundado os conteúdos a serem ensinados e a identificarem as dificuldades de aprendizagem relacionadas a aspectos característicos da química, de modo que estejam

\footnotetext{
${ }^{6} \mathrm{O}$ conhecimento do conteúdo refere-se aos conteúdos químicos em si, enquanto o conhecimento pedagógico ou didático dos conteúdos está relacionado com os conhecimentos elaborados pelos professores em sua prática docente que orientam suas decisões em sala de aula em prol da aprendizagem dos estudantes sobre determinado conteúdo (Shulman,1986).
} 
capacitados para preparar e conduzir atividades que promovam a aprendizagem significativa dos alunos em química.

Portanto, a presente pesquisa defende a ideia de que a inclusão de discussões e reflexões acerca da natureza da ciência, de modo geral e da química, em particular, na educação científica favorece a formação de cidadãos alfabetizados cientificamente e capazes de atuar na sociedade de maneira responsável e consciente. Ademais, se coaduna com a noção de que ideias, fatos e conceitos científicos devem ser ensinados de modo articulado com os processos pelos quais estes foram construídos, bem como com os procedimentos, valores e modos de pensar que caracterizam a química.

\subsection{Dificuldades para a inclusão da HFC no ensino de ciências}

Não obstante as evidências do papel relevante das reflexões provenientes da HFC e, mais especificamente, da história e da filosofia da química para a formação de professores e estudantes, e da sua inclusão, em alguma medida, nas diretrizes curriculares oficiais, investigações recentes têm constatado que os professores, de maneira geral, não realizam discussões filosóficas e históricas acerca da ciência em sala de aula.

O projeto History and Philosophy in Science Teaching (HIPST), que abrange dez grupos de pesquisadores de sete países europeus e Israel, analisou o grau de implantação da HFC no ensino de ciências em alguns países e constatou que os professores, em geral, não possuem a competência e o interesse necessários para ensinar ciências sob essa perspectiva (Höttecke e Silva, 2011).

Diversas pesquisas têm procurado compreender os motivos pelos quais os professores não têm preparado situações pedagógicas nas quais os alunos possam experimentar, levantar hipóteses, argumentar, bem como refletir sobre a ciência, o seu desenvolvimento e suas relações com a sociedade.

Em sua análise sobre a preferência dos docentes pela exposição de informações em detrimento das atividades em grupo, Osborne e colaboradores (2002) concluem que os professores agem em sala de aula de acordo com uma cultura disciplinar, segundo a qual ensinar ciências significa transmitir um corpo bem estabelecido de conhecimentos consensuais, os quais não estão sujeitos à contestação e questionamento. Como consequência, segundo o autor, os 
professores procuram convencer os estudantes da validade da visão científica sobre o mundo e, assim, tendem a suprimir de suas aulas, os assuntos, como alguns relacionados a HFC, que demandam discussões, opiniões e interpretações.

Aikenhead (2003), ao abordar as perspectivas humanísticas no ensino de ciências, aponta como possível causa para a rejeição dos professores à aplicação de um currículo de ciências mais humanístico, a questão da auto-identidade do professor. Segundo esse autor:

Normalmente, os professores de ciências são atraídos para, e uniformemente socializados em disciplinas específicas nos programas universitários nos quais são certificados como leais guardiões e porta-vozes da ciência; e, em contrapartida, gozam de um status profissional e uma auto-identidade associados com a comunidade científica (Aikenhead, 2003, p. 36).

Em decorrência disso, os professores tenderiam a se orientar por um currículo tradicional e a desprezar o ensino contextualizado e centrado nos estudantes, no qual a abordagem de questões epistemológicas teria um importante papel.

Lopes (1999), ao discutir a organização escolar, aponta que a constituição das disciplinas de ciências foi mais influenciada por fatores internos - relativos, dentre outros, à ciência de referência e aos critérios epistemológicos - do que por fatores externos - concernentes à estrutura política, econômica, social e a critérios sociológicos. Como resultado, segundo a pesquisadora, os professores de física e de química se apegam de tal maneira aos conteúdos definidos para estas disciplinas que negam a influência dos fatores externos.

Cachapuz e colaboradores (2005) avaliam que conceber o ensino de ciências como a mera aplicação prática dos conhecimentos oriundos das ciências da educação pode resultar na desconsideração da importância da epistemologia da ciência para a educação científica. Investigações recentes constataram ainda que os docentes não veem a necessidade da HFC em suas aulas, pois não consideram a aprendizagem da natureza da ciência como um objetivo importante na formação integral dos alunos (Höttecke e Silva, 2011). Em pesquisa com professores de física, Martins (2007) constatou que, de modo geral, eles consideram a HFC como um conteúdo periférico a ser utilizado, se houver tempo, apenas para introduzir temas científicos e motivar os alunos. 
Barnett e Hodson (2001) mostram que os docentes têm a tendência a rejeitar conhecimentos, como os relacionados à natureza da ciência, que aumentam sua ansiedade e insegurança em sala de aula. Há ainda os professores que consideram o uso da HFC importante, mas não têm ideia de como utilizar tal abordagem na sala de aula (Wang e Cox-Peterson, 2002).

De acordo com Höttecke e colaboradores (2012), os principais obstáculos para a inserção da HFC na educação científica, considerando o ensino de física, além da cultura disciplinar, são a falta de habilidades profissionais para ensinar sobre a natureza da ciência, somada com visões inadequadas sobre a ciência e o seu ensino, bem como a ausência de um currículo e de conteúdos adequados sobre a HFC em materiais didáticos.

Abd-El-Khalick (2013) indica que, embora necessária, a compreensão dos professores acerca da natureza da ciência não é suficiente para a promoção do ensino sobre e com a natureza da ciência. O autor aponta que a tradução de tal compreensão na prática docente é mediada por fatores como

gestão da sala de aula; crenças docentes sobre a importância dos
estudantes aprenderem acerca da natureza da ciência; percepções
dos professores sobre habilidades e motivação dos estudantes para
aprender sobre a natureza da ciência; prioridades curriculares;
pressões para cobrir o conteúdo científico e preparar os alunos para
os exames padronizados de alto impacto e disponibilidade de
materiais e avaliações educacionais específicas para a
aprendizagem da natureza da ciência (p. 13).

Com respeito à inclusão de discussões acerca dos aspectos característicos da química, visto que o desenvolvimento da filosofia da química é recente, não se espera que suas contribuições tenham se disseminado amplamente na educação. No entanto, alguns pesquisadores ressaltam que, no ensino de química atual, ainda marcado pela transmissão de conceitos químicos, não há espaço para a consideração de aspectos da natureza do conhecimento químico. Segundo Erduran (2001), por exemplo, os docentes continuam a transmitir modelos durante as aulas de química e utilizá-los apenas com o intuito de distinguir conceitos, não preparando atividades de modelagem nas quais os estudantes possam refletir sobre os motivos, argumentos e objetivos envolvidos na construção, aceitação e revisão dos modelos químicos. 
Uma possível causa para a falta de considerações sobre a natureza da química no ensino básico é apontada por Talanquer (2013). Segundo ele, alguns currículos e propostas de ensino continuam se baseando em uma visão geral de ciência, negligenciando, assim, aspectos filosóficos, históricos e sociológicos acerca da química e de seu desenvolvimento. Além disso, a ausência de discussões filosóficas em livros didáticos voltados para o ensino superior, e de reflexões sobre como a química funciona nos cursos de formação inicial, pode influenciar o modo como os estudantes, futuros professores, concebem os objetivos da educação em química e os conteúdos a serem ministrados (Lemes, 2013; Rozentalski, 2013).

\subsection{O estudo acerca das concepções docentes}

O interesse pelo estudo das crenças e concepções docentes teve início na década de 1970, quando as pesquisas educacionais, influenciadas, em certa medida, por investigações em ciência cognitiva, mudaram seu foco de estudo do comportamento docente para o pensamento e o processo de tomada de decisão dos professores. (Thompson, 1992).

Pajares (1992) aponta uma longa lista de termos utilizados nos estudos sobre as crenças docentes: atitudes, valores, julgamentos, axiomas, opiniões, imagens orientadoras, ideologia, percepções, concepções, sistemas conceituais, disposições, teorias implícitas, teorias pessoais, conhecimento prático pessoal, e perspectivas.

Em função da proximidade conceitual entre esses termos, há posições divergentes acerca de seus significados. Wallace (2014) aponta que um dos principais debates na literatura a respeito desta temática tem sido a distinção entre os termos conhecimentos e crenças. Alguns estudiosos, mostra a autora, relacionam o termo crenças com aspectos afetivos e avaliativos que não estariam presentes na construção do conhecimento, enquanto outros definem o termo conhecimento com base na experiência de modo mais amplo. Baptista (2010) aponta que, para alguns autores, os termos concepção e crença são análogos, porém diferem do termo conhecimento; outros conceituam o termo concepções de maneira ampla, contemplando crenças e conhecimentos. Levin (2015) considera que as investigações mais atuais reconhecem a relação estreita entre conhecimento e crença docente. De acordo com a autora, 
os pesquisadores têm reconhecido que crenças tendem a ser subjetivas e pessoais, e refletem o julgamento individual e a interpretação de um conhecimento aceito por uma comunidade ( $p$. 49).

Wallace (2014) enfatiza que, apesar da complexidade envolvida na definição exata dos termos utilizados nos estudos acerca de concepções docentes, há suposições sobre o assunto amplamente aceitas pelos pesquisadores, tais como:

- Crenças influenciam mais os docentes a estruturar, analisar e resolver problemas do que conhecimentos acadêmicos;

- Determinadas crenças são periféricas, enquanto outras são centrais e, por isso, mais resistentes a mudanças;

- Crenças não existem de maneira independente umas das outras: estão organizadas em uma "estrutura interna" de sistemas que têm importância psicológica para o indivíduo;

- Pode haver crenças concorrentes acerca de uma mesma questão;

- A mudança de uma crença pode afetar outras;

- O sistema de crenças ocorre em conjuntos de crenças, centrais e periféricas, interligadas ou agrupadas, sobre vários assuntos.

Fives e Buehl (2012) consideram que os professores possuem, simultaneamente, muitos tipos distintos de crenças, que podem agir como filtros para interpretar e avaliar informações e experiências, como estruturas para lidar com problemas e situações, ou ainda como guia para as ações.

Levin (2015) também chama a atenção para as pesquisas que enfatizam a influência dos contextos social, cultural, político e histórico, os quais os professores vivenciam em sua carreira, em suas crenças.

Assim, um dos fatores mais importantes para que inovações curriculares como a inserção de elementos da HFC nas aulas - sejam bem-sucedidas, é o próprio docente, que no decorrer de sua experiência como aluno e profissional interioriza determinados conhecimentos, competências, técnicas, crenças e valores, os quais são utilizados na prática pedagógica irrefletidamente, mas com muita convicção (Tardif, 2002). Os professores, em geral, tendem a reproduzir os 
processos com os quais estiveram envolvidos enquanto alunos. Pérez ${ }^{7}$ (1988, apud Maldaner, 2000, p. 54) "admite como fato indiscutível que os professores não aplicam os métodos que Ihes foram 'predicados' mas os métodos que Ihes foram aplicados". Assim, os professores podem não aplicar as recomendações das pesquisas e os currículos que lhes foram prescritos, pois suas decisões em sala de aula dependem de inúmeros fatores.

A esse respeito, Mellado (2011) considera que, antes mesmo de ingressarem na graduação, os futuros docentes já possuem concepções, atitudes e valores em relação à ciência e a seu ensino, bem como a respeito das disciplinas científicas, que são resultado do próprio processo de escolarização pelo qual passaram, e que influenciam suas práticas pedagógicas. O autor aponta ainda a complexidade envolvida na relação entre concepção, atitudes e valores e a prática docente, a qual depende tanto de fatores emocionais quanto cognitivos. Mellado (2011) também pondera que, em sua formação inicial, o professor adquire o que ele denomina como conhecimento acadêmico-base, constituído pelos conhecimentos científicos, os conhecimentos psicopedagógicos gerais, os conteúdos da didática das ciências e outros conteúdos culturais adicionais. Segundo Mellado, é com base nesses conhecimentos, filtrados pelas concepções, valores, atitudes e emoções, que se gera e desenvolve o conhecimento didático do conteúdo.

Lopes (1999), com base na visão crítica de currículo, destaca que "não há ensino sem o reconhecimento, por parte dos atores envolvidos, da legitimidade da coisa ensinada" (p. 64).

Desse modo, tendo em vista os referenciais teóricos apresentados neste capítulo, considera-se relevante o estudo das concepções docentes acerca da abordagem de aspectos da natureza da ciência e da química no ensino, de modo a contribuir para que o trabalho pedagógico com tais questões - mais do que apenas ser recomendado nas diretrizes curriculares - faça parte da prática cotidiana dos professores.

7 PÉREZ, M. F. La profesionalizacion del docente. Madrid: Editorial Escuela Española, 1988. 


\section{CAPÍTULO 02 - OBJETIVOS E METODOLOGIA}

\subsection{Objetivos}

Esta pesquisa teve como finalidade caracterizar e compreender as concepções de professores de química do ensino médio a respeito da inclusão de elementos da HFC na sala de aula, com foco nas características específicas da química.

\subsection{Percurso metodológico}

Tendo em vista a consecução do objetivo proposto, optou-se por uma metodologia baseada na investigação qualitativa, centrada na análise de entrevistas com docentes de química que atuam no ensino médio.

Como referencial metodológico para a elaboração do instrumento de recolha de dados utilizou-se as contribuições de Bogdan e Biklen (1994) a respeito das possibilidades de utilização de entrevistas em pesquisas de caráter qualitativo, e de como estruturá-las em consonância com as finalidades estabelecidas. De acordo com Bogdan e Biklen (1994), os dados coletados em uma pesquisa qualitativa devem ser analisados em toda a sua riqueza, evitando-se reduzi-los a meros símbolos numéricos. Ademais, nesse tipo de abordagem o significado tem importância vital. Logo, é importante o estabelecimento de estratégias e métodos que favoreçam a apreensão das perspectivas dos sujeitos participantes.

\subsubsection{Participantes do estudo}

Os participantes da investigação foram escolhidos com base na ideia de que, nas instituições públicas de ensino, os docentes teriam mais autonomia para tratar de assuntos sobre a natureza da química do que em sistemas de ensino privados, os quais, em sua maioria, adotam materiais didáticos tradicionais, orientados principalmente à aprovação dos estudantes em exames vestibulares. Além disso, dado que se pretendia utilizar, na elaboração do roteiro de entrevistas, algumas 
questões envolvendo a natureza da ciência contidas nos cadernos de atividades da rede estadual de ensino de São Paulo, era desejável que os sujeitos conhecessem e tivessem tido algum contato com esse material ou, ao menos, com parte dele.

Desse modo, foram selecionados cinco professores de química de ensino médio de escolas públicas da região metropolitana de São Paulo. Quatro desses sujeitos (P1, P2, P4 e P5) trabalham na rede estadual e um (P3) na rede municipal da Capital. Embora atue em uma escola do município e, por isso, não utilize em sua prática cotidiana o material didático proposto para o ensino de química na rede estadual, P3 atendeu aos critérios estabelecidos previamente, pois já utilizou parte desse material para preparar atividades didáticas. Ademais, o docente conhece e faz uso dos livros produzidos pelo Grupo de Pesquisa em Educação Química da Universidade de São Paulo (GEPEQ-USP), os quais, em certa medida, são semelhantes ao material didático da rede estadual de São Paulo. ${ }^{8}$

\subsubsection{Caracterização dos sujeitos de pesquisa}

\section{Sujeito P1}

\begin{tabular}{|c|c|}
\hline Formação & $\begin{array}{l}\text { Bacharel e licenciado em Química pela Universidade Estadual de } \\
\text { Campinas (UNICAMP), começou a cursar o mestrado em Química na } \\
\text { Universidade de São Paulo (USP), mas não concluiu. Também fez } \\
\text { especialização à distância pela Universidade Estadual Paulista (UNESP). }\end{array}$ \\
\hline $\begin{array}{c}\text { Experiência } \\
\text { em outras } \\
\text { áreas }\end{array}$ & $\begin{array}{l}\text { Começou sua carreira na indústria ainda no ensino secundário. Atuou } \\
\text { como menor aprendiz do Serviço Nacional de Aprendizagem Industrial } \\
\text { (SENAI), onde fez o curso técnico em Mecânica Geral. Ficou oito anos em } \\
\text { empresas nessa área. Depois, trabalhou muitos anos como químico, em } \\
\text { diferentes indústrias, viajando para várias cidades do Estado de São } \\
\text { Paulo para ministrar cursos e promover produtos para clientes. }\end{array}$ \\
\hline & $\begin{array}{l}\text { Iniciou sua carreira docente como professor de física há } 40 \text { anos. } \\
\text { Posteriormente, passou a ministrar aulas de química em um curso } \\
\text { supletivo. Mais tarde atuou como professor de colégio e curso pré- } \\
\text { vestibular de uma rede privada, onde ficou até o ano de 1982. Em 1986, } \\
\text { começou a atuar como professor de química inorgânica em uma }\end{array}$ \\
\hline
\end{tabular}

\footnotetext{
8 Os autores responsáveis pela elaboração desse material fazem parte do GEPEQ-USP.
} 


\begin{tabular}{|l|l|}
\hline instituição de ensino superior, concomitantemente com seu trabalho na \\
indústria. Depois de um tempo na indústria, sem ministrar aulas, passou a \\
atuar como professor de ETEC ${ }^{9}$ É professor na rede estadual de São \\
Paulo desde 2004. Atualmente, atua na ETEC e em uma escola estadual \\
regular, com um total de aproximadamente 40 aulas semanais.
\end{tabular}

\section{Sujeito P2}

\begin{tabular}{|c|c|}
\hline Formação & $\begin{array}{l}\text { Graduada em Ciências, com habilitação em Química, pelo Centro } \\
\text { Universitário Fundação Santo André (CUFSA) e licenciada pela } \\
\text { Universidade do Grande ABC, possui mestrado profissional em Ensino de } \\
\text { Ciências e Matemática pela Universidade Cruzeiro do Sul (UNICSUL). } \\
\text { Atualmente é doutoranda na UNICSUL em Ensino de Ciências e } \\
\text { Matemática. }\end{array}$ \\
\hline $\begin{array}{c}\text { Experiência } \\
\text { em outras } \\
\text { áreas }\end{array}$ & Não possui experiência em outras áreas \\
\hline & $\begin{array}{l}\text { Sua primeira experiência docente foi ainda na graduação, onde } \\
\text { desenvolveu um trabalho de monitoria junto aos estudantes. Começou } \\
\text { lecionando a disciplina de matemática na rede estadual de São Paulo há } \\
23 \text { anos. Após quatro anos, iniciou o trabalho como professora de } \\
\text { ciências nas redes privada, estadual e municipal. Depois, passou a atuar } \\
\text { também como professora de química. Atualmente, é professora efetiva da } \\
\text { rede estadual de São Paulo, com uma carga horária de } 28 \text { aulas } \\
\text { semanais, e ensina os componentes curriculares de ciências e química. } \\
\text { Atua também em uma instituição privada de ensino superior, na qual } \\
\text { leciona, dentre outras, a disciplina de prática de ensino de química. }\end{array}$ \\
\hline
\end{tabular}

\section{Sujeito P3}

\begin{tabular}{|c|l|}
\hline \multirow{2}{*}{ Formação } & $\begin{array}{l}\text { Licenciado em Ciências, com habilitação em Química pela Universidade } \\
\text { Federal Rural de Pernambuco (UFRPE), o docente também iniciou o } \\
\text { curso de Química Industrial, mas não concluiu. Com relação à formação } \\
\text { para a docência, fez alguns cursos para o ensino de química oferecidos }\end{array}$ \\
\hline
\end{tabular}

${ }^{9}$ As ETECs são Escolas Técnicas Estaduais, distribuídas por 159 municípios do Estado de São Paulo. 


\begin{tabular}{|c|l|}
\hline \multirow{2}{*}{$\begin{array}{c}\text { Experiência } \\
\text { em outras } \\
\text { áreas }\end{array}$} & $\begin{array}{l}\text { pelo Grupo de Pesquisa em Educação em Química (GEPEQ) do IQ-USP. } \\
\text { O docente também fez o curso de Comunicações das Artes do Corpo na } \\
\text { PUC-SP, e é mestre em Artes pela Universidade Estadual Paulista } \\
\text { (UNESP). } \\
\text { no controle de qualidade. Atualmente, além de professor, é ator em uma } \\
\text { companhia de teatro. }\end{array}$ \\
\hline $\begin{array}{l}\text { Carreira } \\
\text { docente }\end{array}$ & $\begin{array}{l}\text { Professor há } 26 \text { anos. Iniciou sua carreira docente dando aulas de } \\
\text { ciências para o ensino fundamental em uma instituição privada, durante } \\
\text { um ano. Atualmente, atua apenas na rede municipal de São Paulo, } \\
\text { lecionando para o ensino médio e magistério, com uma carga horária de } \\
40 \text { horas. }\end{array}$ \\
\hline
\end{tabular}

\section{Sujeito P4}

\begin{tabular}{|c|l|}
\hline \multirow{2}{*}{ Formação } & $\begin{array}{l}\text { Engenheira química pela Universidade Federal de Minas Gerais (UFMG) } \\
\text { e mestre na área de Alimentos e Nutrição pela Universidade Estadual de } \\
\text { Campinas (UNICAMP). Iniciou, mas não concluiu, o doutorado em } \\
\text { Fitoquímica na Universidade de São Paulo (USP). Também é licenciada } \\
\text { em Química e Ciências pela Faculdade Oswaldo Cruz. }\end{array}$ \\
\hline $\begin{array}{c}\text { Experiência } \\
\text { em outras }\end{array}$ & $\begin{array}{l}\text { Apesar de ser formada em Engenharia Química nunca atuou na indústria. } \\
\text { Seguiu carreira na área da pesquisa, onde ficou por oito anos, antes de } \\
\text { trabalhar na educação básica. }\end{array}$ \\
\hline $\begin{array}{c}\text { Carreira } \\
\text { docente }\end{array}$ & $\begin{array}{l}\text { Atua como professora de química há 20 anos. Iniciou a carreira docente } \\
\text { como professora nas redes privada e estadual. Atualmente, ministra trinta } \\
\text { e duas aulas de química na rede estadual. Para completar a carga } \\
\text { horária, em alguns anos, também leciona os componentes curriculares de } \\
\text { ciências e de física. }\end{array}$ \\
\hline
\end{tabular}

\section{Sujeito P5}

\begin{tabular}{|c|l|}
\hline Formação & $\begin{array}{l}\text { Bacharel e licenciada em Química pela Faculdade Oswaldo Cruz. Chegou } \\
\text { a fazer o curso de Engenharia Mecânica, mas ficou pouco tempo. }\end{array}$ \\
\hline $\begin{array}{c}\text { Experiência } \\
\text { em outras } \\
\text { áreas }\end{array}$ & Foi bancária durante dez anos antes de fazer a graduação. \\
\hline
\end{tabular}




\begin{tabular}{|l|l|}
\hline \multirow{2}{*}{$\begin{array}{l}\text { Carreira } \\
\text { docente }\end{array}$} & $\begin{array}{l}\text { Iniciou sua carreira docente há vinte e cinco anos. Começou na escola } \\
\text { privada e depois ingressou na rede estadual. Posteriormente também } \\
\text { passou a atuar como docente de disciplinas de química em uma ETEC. } \\
\text { Atualmente, continua atuando na rede privada, estadual e na ETEC, e } \\
\text { possui um total de cinquenta e sete aulas semanais. }\end{array}$ \\
\hline
\end{tabular}

\subsubsection{Recolha de dados}

Para as finalidades do presente estudo, a entrevista se constituiu em um instrumento adequado para revelar as ideias, opiniões e condutas relacionadas à HFC e à sua inclusão nas aulas de química. Para Duarte (2004), as entrevistas são fundamentais para "mapear práticas, crenças, valores e sistemas classificatórios de universos sociais específicos, mais ou menos bem delimitados, em que os conflitos e contradições não estejam claramente explicitados” (p. 215). Assim, as entrevistas permitem obter informações de natureza subjetiva, por meio das quais se pode descrever e compreender o modo como os sujeitos percebem e significam aspectos de sua realidade. Mais especificamente, optou-se pela entrevista semi-estruturada, caracterizada pela combinação de questões abertas e fechadas, "em que o entrevistado tem a possibilidade de discorrer sobre o tema em questão sem se prender à indagação formulada" (Minayo, 1992, p. 261). A utilização desse tipo de entrevista permite explorar as respostas dadas pelos sujeitos e fazer intervenções com o intuito de ampliar as questões elaboradas previamente e aprofundar as informações fornecidas por eles. Ademais, favorece a obtenção de dados comparáveis entre os vários sujeitos participantes (Bogdan e Biklen, 1994).

\subsubsection{Elaboração e aplicação do instrumento para a recolha dos dados}

Inicialmente, elaborou-se um roteiro preliminar com o intuito de adequar as questões previamente elaboradas aos objetivos propostos e, caso houvesse necessidade, excluir e incluir perguntas. Esse roteiro foi utilizado nos primeiros encontros com os sujeitos P1 e P2. Após a transcrição e leitura dessas entrevistas, constatou-se a necessidade de reelaborar as perguntas voltadas a investigar, mais diretamente, a concepção dos sujeitos sobre o uso da HFC no ensino, de modo a incluir aspectos mais específicos da química. 
Assim, foi estruturado o roteiro definitivo de entrevista (Apêndice A), cujas questões estão organizadas em nove blocos. Os quatro primeiros, utilizados com os professores entrevistados nos encontros iniciais, foram elaborados com base em pesquisas na área de educação científica que abordam a relevância da HFC e os possíveis obstáculos a sua inserção no ensino. A finalidade de cada um desses blocos está descrita no Quadro 01 a seguir.

\begin{tabular}{|l|l|}
\hline \multicolumn{1}{|c|}{ Blocos } & \multicolumn{1}{c|}{ Objetivos } \\
\hline $\begin{array}{l}\text { A - Caracterização do } \\
\text { entrevistado e das } \\
\text { condições de trabalho } \\
\text { docente }\end{array}$ & $\begin{array}{l}\text { Caracterizar os entrevistados, conhecer suas condições de } \\
\text { trabalho e deixá-los mais à vontade para responder às questões } \\
\text { subsequentes. }\end{array}$ \\
\hline B - Identidade docente & $\begin{array}{l}\text { Identificar os fatores e motivos que levaram o entrevistado a atuar } \\
\text { na carreira docente, e se ele se vê mais como porta-voz da } \\
\text { ciência ou cientistas do que como professor (Aikenhead, 2003). }\end{array}$ \\
\hline $\begin{array}{l}\text { C - Saberes } \\
\text { necessários ao trabalho } \\
\text { docente }\end{array}$ & $\begin{array}{l}\text { Identificar se, espontaneamente, os professores incluem assuntos } \\
\text { oriundos da HFC entre suas necessidades formativas e se } \\
\text { consideram o ensino de ciências como uma mera aplicação de } \\
\text { conhecimentos "pedagógicos" de caráter geral (Cachapuz et al., } \\
\text { 2005). Para isso, foram elaboradas perguntas para verificar quais } \\
\text { saberes os docentes consideram necessários ao exercício da } \\
\text { docência na disciplina de química. }\end{array}$ \\
\hline $\begin{array}{l}\text { D - Objetivos } \\
\text { pedagógicos e práticas } \\
\text { docentes }\end{array}$ & $\begin{array}{l}\text { Identificar se o professor está inserido em uma cultura disciplinar } \\
\text { que compreende o ensino de ciências como a transmissão de um } \\
\text { corpo fechado de conhecimentos verdadeiros e cujas práticas, } \\
\text { portanto, não contemplam a discussão aberta, os } \\
\text { questionamentos e a contestação. Para isso, foram elaboradas } \\
\text { perguntas para investigar os principais objetivos dos docentes ao } \\
\text { ensinar química e as estratégias e conteúdos que consideram } \\
\text { imprescindíveis para atingir esses objetivos (Osborne et al., 2002; } \\
\text { Lopes, 1999; Aikenhead, 2003). }\end{array}$ \\
\hline
\end{tabular}

Quadro 01: Objetivos dos primeiros quatro blocos do roteiro de entrevista.

Os últimos cinco blocos do roteiro de entrevista tiveram como finalidade investigar as concepções dos participantes sobre o trabalho pedagógico com assuntos da natureza da ciência e da química. Para sua elaboração, primeiramente foram definidas quais discussões sobre a química e a ciência seriam o foco das entrevistas e, consequentemente, de toda a investigação. Tal tarefa foi realizada tendo como referência a noção de "semelhança de família", utilizada por Irzik e Nola (2011) para sugerir uma alternativa à visão consensual da natureza da ciência, segundo a qual as disciplinas científicas, embora possuam diferentes características, também têm uma série de semelhanças, entrecruzamentos e sobreposições que Ihes fornece suficiente unidade. Assim, em vez de questionar os entrevistados sobre 
uma lista de características que, supostamente, seriam suficientes para classificar determinado empreendimento como científico, optou-se por elaborar as perguntas a partir de temas, os quais permitissem discussões sobre aspectos mais específicos da química e outros, comuns à ciência, de modo geral.

A construção dos temas foi realizada com base em: a) estudos sobre aspectos consensuais da natureza da ciência (Akerson et al., 2000; Lederman et al., 2002; Osborne et al., 2003); b) discussões acerca das características específicas do conhecimento químico (Chamizo, 2013; Erduran, 1999, 2001; Erduran e Scerri, 2002; Izquierdo-Aymerich, 2013; Justi, 2010; Lemes, 2013; Porto, 2010; Talanquer, 2013; Vesterinen, 2012; Schumacher \& Reiners, 2013) e c) informações, capacidades e valores, relativos à natureza da química, considerados relevantes pelas diretrizes curriculares oficiais para a formação integral dos estudantes do ensino médio (Brasil, 1999, 2002, 2006).

No Quadro 10 (Apêndice B) foram relacionados os temas selecionados; os motivos pelos quais foram escolhidos; as características principais da natureza da química e da ciência associadas a eles; bem como trechos de orientações contidas em documentos curriculares oficiais com relação à inclusão de elementos da HFC no ensino de química.

Com base em tais informações, foram elaboradas as questões relacionadas aos temas predeterminados. Como apoio a essas perguntas, foram utilizadas atividades que abordam aspectos da natureza da ciência e da química, presentes no material didático da rede estadual de São Paulo, assim como atividades produzidas com base nesse material e em outros estudos na área da educação científica.

O material da rede estadual de São Paulo, utilizado na entrevista, é composto pelos cadernos do Professor e do Aluno, e integra a Proposta Curricular "São Paulo faz Escola”, elaborada em 2008. De acordo com o site da Secretaria de Educação do Estado de São Paulo, essa Proposta tem o intuito de unificar o currículo para todas as escolas, bem como garantir uma base comum de competências e conhecimentos para professores e estudantes. ${ }^{10}$

Especificamente, no que se refere ao componente curricular química, o material didático foi desenvolvido por pesquisadores do Grupo de Pesquisa em Educação Química da Universidade de São Paulo (GEPEQ-USP) e está em

10 Vide: http://www.educacao.sp.gov.br/curriculo. Acesso em: 5 out. 2015. 
consonância com os Parâmetros Curriculares Nacionais para o Ensino Médio. Desse modo, seus autores preconizam a importância de se compreender

os processos químicos em estreita relação com suas aplicações tecnológicas, ambientais e sociais, de modo a poder tomar decisões de maneira responsável e crítica e emitir juízos de valor, em nível individual ou coletivo. (SÃO PAULO, 2011, p.126).

Além disso, seus autores defendem a abordagem dos conhecimentos químicos como construções históricas provisórias.

No Quadro 02 estão descritos os objetivos das questões elaboradas para os cinco últimos blocos do roteiro de entrevista, e as atividades com as quais estão relacionadas (todas as atividades referidas aqui estão incluídas no Apêndice $A$ ).

\begin{tabular}{|c|c|c|}
\hline \multicolumn{3}{|c|}{ Bloco E - Relações com a sociedade } \\
\hline Objetivos & Atividades relacionadas & Questões \\
\hline $\begin{array}{l}\text { Investigar se os docentes abordam os } \\
\text { aspectos históricos, econômicos e } \\
\text { culturais associados ao } \\
\text { desenvolvimento da síntese da } \\
\text { amônia e se colocam a compreensão } \\
\text { desses assuntos entre os seus } \\
\text { objetivos. }\end{array}$ & $\begin{array}{l}\text { Situação de Aprendizagem 02: Estudo } \\
\text { da síntese e da produção industrial da } \\
\text { amônia a partir dos gases nitrogênio e } \\
\text { hidrogênio (Material da rede estadual } \\
\text { de São Paulo, 3a série EM, v. 1, } \\
\text { Caderno do Aluno, p. 9-19). }\end{array}$ & 01 a 04 \\
\hline $\begin{array}{l}\text { Levantar as concepções dos } \\
\text { docentes sobre a abordagem de } \\
\text { questões como: as relações } \\
\text { simbióticas entre a química e a } \\
\text { indústria; a pesquisa guiada pela } \\
\text { exigência da agricultura e da } \\
\text { indústria; o papel da tecnologia no } \\
\text { processo Haber-Bosch; os fatores } \\
\text { éticos envolvidos no desenvolvimento } \\
\text { desse processo; e as implicações } \\
\text { ambientais e sociais decorrentes dele. }\end{array}$ & $\begin{array}{l}\text { Atividade } A \text {, elaborada com base na } \\
\text { Situação de Aprendizagem } 02 \text {. }\end{array}$ & 05 a 07 \\
\hline \multicolumn{3}{|c|}{ Bloco F - Modelos e modelagem } \\
\hline Objetivos & Atividades relacionadas & Questões \\
\hline $\begin{array}{l}\text { Verificar se os professores abordam } \\
\text { questões sobre a natureza da química } \\
\text { e da ciência subjacentes ao estudo de } \\
\text { modelos e, caso trabalhem sob essa } \\
\text { perspectiva, levantar as estratégias } \\
\text { utilizadas para tratar desse tema em } \\
\text { sala de aula. }\end{array}$ & & 01 a 03 \\
\hline Levantar 0 que os professores & Atividade $B$, elaborada tomando-se por & 04 a 07 e \\
\hline
\end{tabular}




\begin{tabular}{|c|c|c|}
\hline $\begin{array}{l}\text { pensam sobre a inclusão da } \\
\text { modelagem no ensino de química e } \\
\text { de assuntos envolvendo a natureza } \\
\text { dos modelos, seus limites, sua } \\
\text { abrangência, a complexidade } \\
\text { envolvida em sua construção e o } \\
\text { papel dos cientistas nesse processo. }\end{array}$ & $\begin{array}{l}\text { base estudos sobre modelos e } \\
\text { modelagem no ensino de química } \\
\text { (Mendonça e Justi, 2005; Mendonça, } \\
\text { 2008, 2011). }\end{array}$ & 10 a 13 \\
\hline $\begin{array}{l}\text { Conhecer as concepções dos } \\
\text { docentes a respeito do uso de } \\
\text { atividades sobre modelos com base } \\
\text { em um material didático que, } \\
\text { supostamente, já é conhecido e } \\
\text { utilizado por eles. }\end{array}$ & $\begin{array}{l}\text { Situação de Aprendizagem 04: Modelo } \\
\text { atômico de Dalton: ideias sobre a } \\
\text { constituição e transformação da } \\
\text { matéria: Atividade } 01 \text { e } 02 \text { (Material da } \\
\text { rede estadual de São Paulo, } 1^{\text {a }} \text { série } \\
\text { EM, v. 2, Caderno do Professor, p. } 51 \text {, } \\
52 \text { e Caderno do Aluno, p. } 41-44) \text {. }\end{array}$ & 08 e 09 \\
\hline $\begin{array}{l}\text { Investigar a visão dos professores } \\
\text { sobre discussões acerca da natureza } \\
\text { provisória dos modelos e das } \\
\text { subjetividades envolvidas em seu } \\
\text { processo de elaboração. }\end{array}$ & $\begin{array}{l}\text { Situação de Aprendizagem 01: } \\
\text { Explicando o comportamento de } \\
\text { materiais: modelos sobre a estrutura } \\
\text { da matéria: } 1.2 \text { - Evolução das ideias: } \\
\text { do átomo de Dalton ao átomo de } \\
\text { Rutherford-Bohr (Material da rede } \\
\text { estadual de São Paulo, 2a série EM, v. } \\
\text { 2, Caderno do Aluno, p 11-19 e } \\
\text { Caderno do Professor, p. 12). } \\
\text { Atividade C, elaborada com base nas } \\
\text { atividades dessa Situação de } \\
\text { Aprendizagem. }\end{array}$ & 14 a 16 \\
\hline \multicolumn{3}{|c|}{ Bloco G - Experimentação } \\
\hline Objetivos & Atividades relacionadas & Questões \\
\hline $\begin{array}{l}\text { Investigar se os docentes incentivam } \\
\text { a reflexão sobre a experimentação } \\
\text { científica e preparam atividades nas } \\
\text { quais os estudantes sejam } \\
\text { estimulados a elaborar, testar e } \\
\text { comunicar suas hipóteses, ideias e } \\
\text { conclusões. Também visam investigar } \\
\text { os motivos pelos quais realizam ou } \\
\text { não esse tipo de atividade. }\end{array}$ & & 01 a 05 \\
\hline $\begin{array}{l}\text { Conhecer as concepções dos } \\
\text { professores sobre o uso de atividades } \\
\text { que se aproximem da prática química } \\
\text { autêntica. Investigar se os docentes } \\
\text { discutem com os estudantes aspectos } \\
\text { da natureza da ciência relativos à } \\
\text { experimentação, tais como a } \\
\text { negociação social de seus métodos e } \\
\text { resultados, a cooperação envolvida }\end{array}$ & $\begin{array}{l}\text { Atividade } D \text {, elaborada com base em } \\
\text { Paixão e Cachapuz, 2000; Allchin, } \\
2015 \text { e Fabricio et al., 2011. }\end{array}$ & 06 a 10 \\
\hline
\end{tabular}




\begin{tabular}{|c|c|c|}
\hline $\begin{array}{l}\text { na produção do conhecimento } \\
\text { científico, assim como a natureza } \\
\text { inferencial e criativa envolvida na } \\
\text { interpretação } \\
\text { estudados. }\end{array}$ & & \\
\hline $\begin{array}{l}\text { Investigar a concepção dos } \\
\text { professores sobre a abordagem de } \\
\text { algumas discussões realizadas na } \\
\text { área da filosofia da química, tais } \\
\text { como o papel da experimentação, das } \\
\text { teorias e da instrumentação na } \\
\text { química. }\end{array}$ & $\begin{array}{l}\text { Atividade } E, \quad \text { a respeito da } \\
\text { experimentação na ciência química. }\end{array}$ & 11 \\
\hline \multicolumn{3}{|c|}{ Bloco H - Reducionismo } \\
\hline Objetivos & Atividades relacionadas & Questões \\
\hline $\begin{array}{l}\text { Verificar se os professores, ao } \\
\text { abordar o assunto propriedades da } \\
\text { matéria, incentivam os estudantes a } \\
\text { refletirem sobre as representações } \\
\text { químicas e as relações entre os níveis } \\
\text { macroscópico e microscópico. }\end{array}$ & $\begin{array}{l}\text { Situação de Aprendizagem 01: Forças } \\
\text { de Interação entre Partículas nos } \\
\text { Estados Sólido, Líquido e Gasoso: } \\
\text { Atividade } 04 \text { (Material da rede estadual } \\
\text { de São Paulo, 2a série EM, v. } 3 \text {, } \\
\text { Caderno do Aluno, p. 17-20). } \\
\text { Atividade F, proposta com base no } \\
\text { trabalho de Erduran (2005). }\end{array}$ & 01 e 02 \\
\hline $\begin{array}{l}\text { Investigar quais aspectos os } \\
\text { professores priorizam no trabalho com } \\
\text { o tema equilíbrio químico: os } \\
\text { conceitos químicos ou os cálculos e } \\
\text { as contas envolvidas. }\end{array}$ & 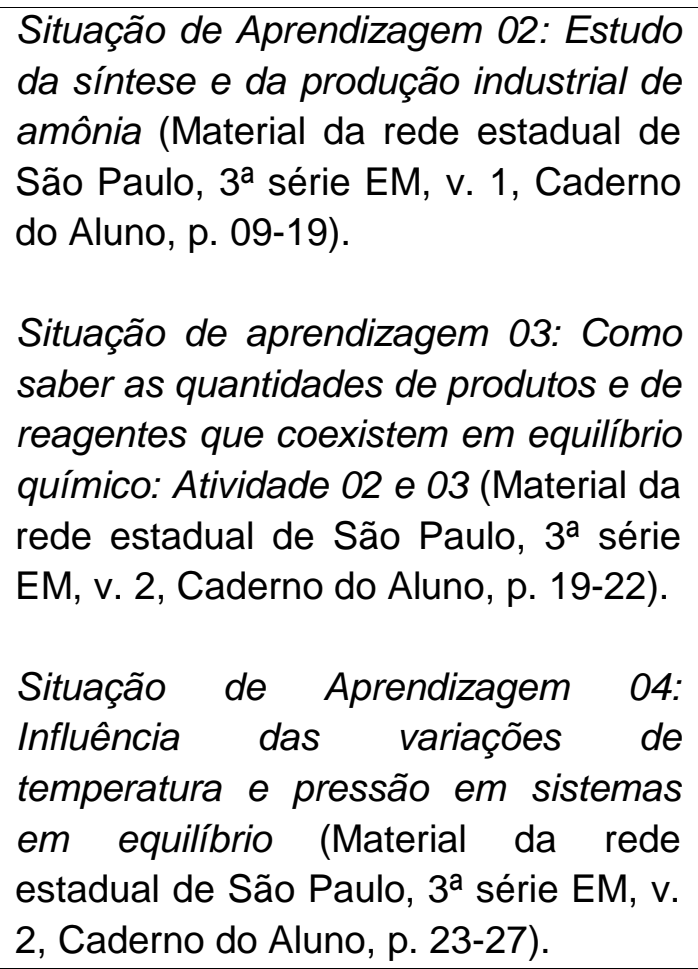 & 03 e 04 \\
\hline \multicolumn{3}{|c|}{ Bloco I - Desenvolvimento histórico } \\
\hline Objetivos & Atividades relacionadas & Questões \\
\hline $\begin{array}{lll}\text { Conhecer a prática docente em } \\
\text { relação à história da ciência: os } \\
\text { docentes trabalham sob essa }\end{array}$ & $\begin{array}{l}\text { Situação de Aprendizagem 02: Estudo } \\
\text { da síntese e da produção industrial de } \\
\text { amônia (Material da rede estadual de }\end{array}$ & 01 e 02 \\
\hline
\end{tabular}




\begin{tabular}{|c|c|c|}
\hline $\begin{array}{l}\text { perspectiva? Em caso afirmativo, } \\
\text { quais são suas estratégias? Quais } \\
\text { são os motivos pelos quais trabalham } \\
\text { ou não com a história da química em } \\
\text { sala de aula? }\end{array}$ & 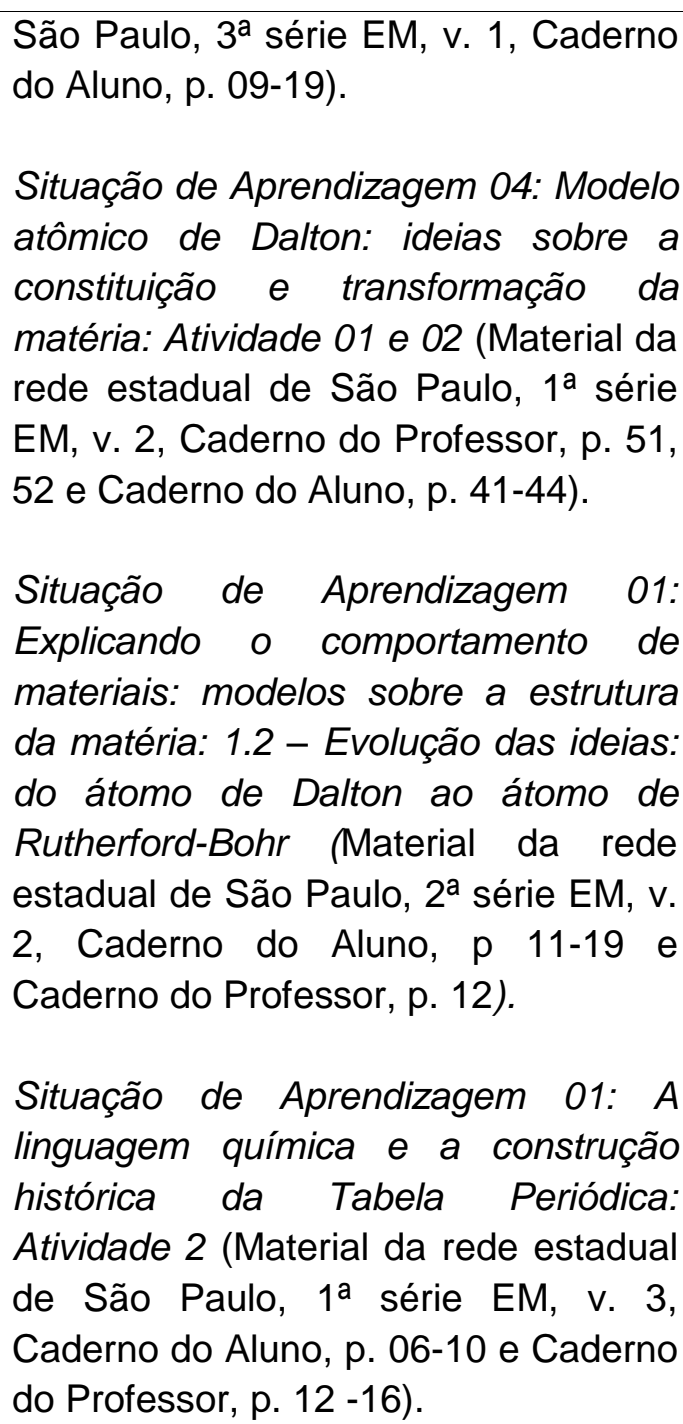 & \\
\hline $\begin{array}{lcr}\text { Levantar as concepções dos } \\
\text { docentes sobre a discussão de } \\
\text { aspectos da natureza da química } \\
\text { tendo por base episódios históricos. }\end{array}$ & $\begin{array}{l}\text { Atividade G, elaborada a partir de } \\
\text { Erduran (2007), Tolvanen et al. (2013) } \\
\text { e Baldwin et al. (2014). }\end{array}$ & 03 e 04 \\
\hline
\end{tabular}

Quadro 02: Objetivos dos últimos cinco blocos do roteiro de entrevista.

Foram realizados diversos encontros com os sujeitos entrevistados, sendo que a maioria aconteceu nas escolas onde os professores lecionam. Por ocasião das entrevistas, foram apresentados os objetivos da pesquisa e o Termo de Consentimento Livre e Esclarecido (Apêndice C), o qual foi lido e assinado pelos participantes. Todas as entrevistas foram registradas em áudio e, em seguida, transcritas na íntegra. ${ }^{11}$

${ }^{11}$ As entrevistas foram transcritas de acordo com as regras de formatação de transcrição de Preti (1999), as quais podem ser consultadas no Anexo A. 


\subsubsection{Análise dos dados}

Neste estudo, a interpretação e compreensão do material obtido foram realizadas com base nas orientações fornecidas por Bogdan e Biklen (1994) e Duarte (2004). Inicialmente, simultaneamente à transcrição, foram registrados comentários preliminares referentes a algumas falas dos sujeitos, principalmente, aquelas concernentes ao processo de ensino e aprendizagem, bem como acerca dos temas abordados. Tomando-se por base essa tarefa inicial, obteve-se o perfil dos sujeitos entrevistados e iniciou-se o processo de organização das falas dos docentes nos eixos temáticos previamente estabelecidos antes da análise dos dados, tendo em conta investigações em ensino de ciências e documentos curriculares oficiais. Primeiro, as respostas dos sujeitos entrevistados, as quais faziam referência direta a discussões sobre aspectos da natureza da química, foram agrupadas sob os temas: relações com a sociedade; modelos e modelagem; experimentação; reducionismo e desenvolvimento histórico. Em seguida, para cada um desses temas foram construídos subtemas correspondentes, mais específicos em relação ao objeto de pesquisa (Duarte, 2004). Posteriormente, em outro nível de análise, foram identificados nas falas dos docentes os fatores que influenciam suas práticas e concepções no que tange a inclusão de aspectos da natureza da ciência e, mais especificamente, da química, no ensino. 


\section{CAPÍTULO 03 - RESULTADOS E DISCUSSÕES}

Tomando por base as respostas dos sujeitos entrevistados - as quais faziam referência direta a discussões pedagógicas envolvendo aspectos da natureza da química e da ciência - foi possível segmentar e organizar as unidades de significação dentro dos temas previamente estruturados a partir do referencial teórico. De maneira geral, as falas provenientes da fragmentação das entrevistas permitiram examinar estratégias e assuntos que os docentes dizem utilizar na abordagem dos assuntos relativos ao tema, assim como a importância que atribuem ou não a essas discussões.

Assim, em relação a cada um dos temas, os quais se referem a aspectos da química, as falas dos docentes foram agrupadas nos subeixos temáticos Prática Docente e Relevância. O subeixo Prática Docente diz respeito aos assuntos, relacionados aos temas, que os sujeitos entrevistados dizem abordar com os estudantes nas aulas de química, assim como algumas estratégias por eles mencionadas. Embora o foco da presente pesquisa não seja conhecer, de modo detalhado, a prática pedagógica dos sujeitos investigados, a análise das estratégias e dos assuntos mencionados por eles, ao refletirem sobre as atividades abordadas nas entrevistas, permite evidenciar alguns aspectos importantes relacionados à utilização de elementos da natureza da química no ensino.

No subeixo Relevância, por sua vez, foram agrupadas as falas nas quais os docentes expressam suas opiniões em relação à importância das questões abordadas. Desse modo, tais falas abrangem desde apreciações negativas acerca do uso de determinadas estratégias e da abordagem de alguns assuntos até considerações acerca das capacidades e dos conhecimentos relevantes na formação dos estudantes, bem como das finalidades de se promover o ensino de tais conteúdos escolares. ${ }^{12}$

Em função das relações existentes entre os diferentes aspectos da química, algumas unidades de texto, extraídas das falas dos participantes, estão agrupadas em mais de um tema.

12 Conteúdo escolar aqui é considerado como habilidades, informações, competências, valores, hábitos, etc., que os docentes consideram relevantes no ensino de química. 
3.1. Concepções sobre história e filosofia da química no ensino

\subsubsection{Relações com a sociedade}

\subsubsection{Prática docente}

As falas a seguir sugerem que, para os docentes P1, P4 e P5, uma das maneiras de se considerar com os estudantes as interações entre a ciência e a sociedade é por meio da apresentação de exemplos de aplicações e processos tecnológicos relacionados aos conteúdos trabalhados.

P1: eu falo "olha pessoal... tem... tem uma aplicação em bomba"... tudo tal... mas....só isso ---

Hirayama: e quais as modificações que você fez aqui no caso?

P4: quais as aplicações da amônia... tem no livro do GEPEQ tem... para que que a amônia é utilizada... fala que ela sempre é... intermediária depois dela se faz sabonete... (...) produto de limpeza... medicamento... explosivo... fertilizante (...) ácido nítrico... né?

----

P5: o que aparece assim com (...) respeito a indústria... por exemplo (...) estou explicando lá os princípios de Le Chatelier eu explico que tem:: que aumentando a pressão vai diminuir o volume tudo com desenhos usando recipientes mais simples (...)

(...)

P5: (...) o que eu falo sobre indústria mesmo (...) é quando eu dou cinética (...) aí eu falo que na indústria é ou acelerar uma reação (...)

P1, ao responder se realizaria, na escola estadual onde atua, algumas discussões sobre a influência dos contextos político, econômico e social no desenvolvimento do processo Haber-Bosch, disse que considera com os estudantes apenas algumas aplicações da amônia. Já P4, ao comentar quais modificações faz ao abordar a Situação de Aprendizagem 02: Estudo da síntese e da produção industrial de amônia, considerou a importância de fornecer aos alunos exemplos de aplicações da amônia, complementares aos mencionados na apostila. P5, por sua vez, comentou que a única relação que estabelece entre a química e a indústria em suas aulas é por meio de exemplos de processos industriais, utilizados com o intuito de ilustrar o conteúdo de cinética química.

Em um estudo recente, Sjöström e Talanquer (2014) consideram que a perspectiva humanística para a educação em química apresenta diferentes níveis de complexidade, os quais abrangem desde a simples contextualização para orientações sócio científicas até a problematização multifacetada dos conhecimentos 
em química e sobre a química. Segundo os pesquisadores, a abordagem dos fenômenos do cotidiano e das diferentes aplicações tecnológicas estaria classificada no primeiro nível, denominado como "química aplicada". Ainda de acordo com eles, apesar desse enfoque representar um passo adiante em relação a um ensino totalmente descontextualizado, a mera utilização de exemplos de modo isolado ou, até mesmo como forma de apresentar os conhecimentos disciplinares, pode limitar a compreensão da ciência como um empreendimento humano, o qual influencia a sociedade e é afetado por ela, bem como a respeito das inter-relações entre a química, a tecnologia, a sociedade e o meio ambiente.

Outra forma, apontada por P3, de se compreender a abordagem das relações entre química e sociedade é pelo uso de temas geradores, conforme se pode verificar nos excertos a seguir.

P3: (...) não verticalizo nada disso... eu aponto... eu proponho mas não vem... eu quero que eles tragam... e não acontece... eu falo "olha... o trabalho sobre conservação de alimentos... questão com foco no tema gerador que é transformação no tema mais especifico que é velocidade mas vocês podem falar por que a gente quer conservar alimento? "(...)

(...)

P3: (...) espero que aconteça... eu dou até um... mas não vem (...) tem um outro tópico lá "tema a escolha... você só não pode fugir do tema gerador"... você não pode escolher qualquer coisa é uma transformação química... e não é dizer o que é... é dizer a velocidade... "por que a gente quer acelerar ou retardar tal coisa? interessa a QUEM isso? (...)

Mesmo que o emprego de temas no ensino de química permita a organização dos conteúdos com base em contextos e, consequentemente, possa favorecer a problematização de aspectos sociais e ambientais nos quais a química está imbricada, o modo superficial como o docente afirma conduzir as atividades restringe sobremaneira o trabalho com esses aspectos. P3 aponta que propõe perguntas iniciais visando motivar a participação dos estudantes nas aulas, mas que, devido à falta de interesse deles, não aprofunda tais discussões. Logo, não há debates e reflexões acerca de questões relevantes associadas, por exemplo, ao tema "alimentos", citado pelo docente, tais como a importância da conservação de alimentos para a sociedade no decorrer da história e atualmente, a escassez de víveres a despeito dos avanços tecnológicos na área, dentre outras.

Além da utilização de temas e da citação pontual de exemplos de produtos e aplicações tecnológicas, os docentes entrevistados mencionaram que abordam com 
os estudantes aspectos ambientais relativos à química, conforme se pode verificar nos excertos abaixo.

P1: já discuti em relação até... o rio Tietê que fica per:.to... né? (...)
(...) P1: já foi discutido em relação a lixo ambiental tudo isso aqui já foi discutido
P4: por exemplo isso não fala quando fala de meio ar eu sei que no material do GEPEQ tem
mas no livrinho deles lá tem um texto de chuva ácida e efeito estufa e não fala ((no material
da rede estadual)) (...) tem a questão lá falando... éh.: que consequências tem para o ser
humano? aí você tem que falar para eles que o texto em si não fala (...)
-.--
P5: ah eu falo sobre meio ambiente (...) no laboratório... por exemplo descarte... "(...)
professora por que não posso jogar nada na pia?” aí eu explico aí eu falo dos efluentes de
indústria então eu eu falo muito sobre... esses problemas... até quan/ninguém... acho que
nenhum dos meus alunos mais joga bateria no lixo... por exemplo... então eu faço com que
eles entendam também sobre... o problema do meio ambiente... não só nesse caso da
ciência da amônia e da indústria... é em geral

De acordo com Sjöström e Talanquer (2014), em relação à mera exemplificação de fatos e fenômenos, a discussão sobre os custos e benefícios sociais, econômicos e ambientais oriundos das atividades químicas está num nível mais complexo de incorporação de questões humanísticas no ensino de química, o qual denominam como "sócio-química". Assim, conteúdos como o lixo ambiental, a poluição da hidrosfera, a chuva ácida e o efeito estufa, citados pelos docentes no trecho acima, podem gerar trabalhos prolíficos acerca das relações existentes entre a química, tecnologia, sociedade e meio ambiente. Entretanto, embora os sujeitos entrevistados não tenham descrito, de modo detalhado, as estratégias utilizadas para tratar essas questões, a maioria deles parece se limitar a apontar e explicar, de modo superficial, algumas consequências ambientais da utilização de produtos e do desenvolvimento de processos químicos.

P5 mencionou também que já abordou assuntos ambientais com os estudantes em uma semana cultural de química.

\footnotetext{
Hirayama: o que você pensa então sobre realizar uma discussão sobre essa relação entre a indústria a tecnologia e a química né? com foco nessas questões ambientais e éticas (...)

P5: então nós já fizemos um trabalho aqui na escola

P5: é foi numa semana cultural de química (...) a gente tem uma galvanoplastia aqui em Santo Amaro

(...)

P5: e eles foram até lá porque eu conheço o dono de lá né? e ele recebeu os alunos para falar sobre o problema de... dos metais pesa:.dos... foi bem... então acho legal eles... eles fazerem isso daí... esse tipo de trabalho
} 
Hirayama: você faz todo ano essa essa essa::...?

P5: não... a cada... assim... a cada três anos tem uma feira de ciências

Apesar de eventos informais, tais como feiras de ciências e mostras culturais poderem favorecer a interdisciplinaridade e a abordagem de temas contextualizados, a fala da docente pode indicar que esses assuntos são trabalhados apenas em ocasiões esporádicas, não fazendo parte de discussões frequentes com os estudantes.

P4, ao se referir à importância das discussões envolvendo química, indústria e questões ambientais, mencionou o uso de notícias que permitem o trabalho com algum conteúdo da química.

P4: (...) quan::.do aparece algum acidente... ou alguma coisa em química que sai no noticiário alguma coisa aí a gente aproveita usa aquele momento para... para falar daquilo... quando é que foi? (...) aquele shopping (...) o pessoal não podia frequentar lá... o Center Norte por causa do metano então o pessoal do terceiro ano foi capaz de entender aquilo tranquilamente...

Embora essa estratégia permita o desenvolvimento de certas habilidades e competências recomendadas pelo documento Orientações Curriculares para o Ensino Médio (Brasil, 2006), tais como

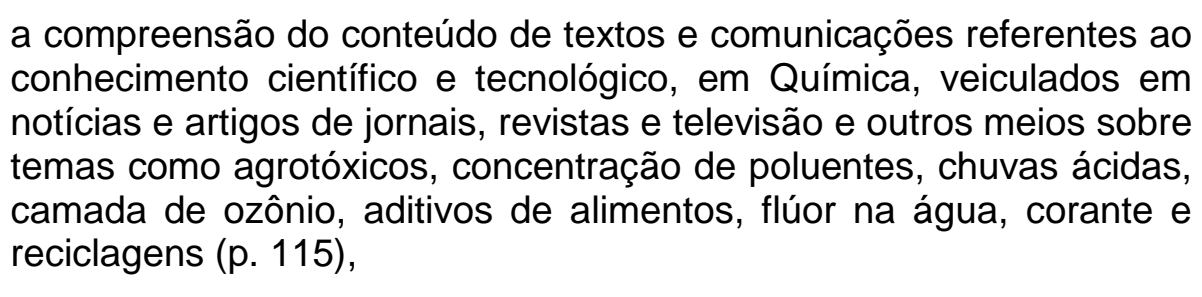

a docente parece utilizá-la apenas em momentos pontuais, o que pode restringir discussões relevantes acerca de assuntos relacionando a química e a sociedade.

Dentre os professores entrevistados, apenas P2 descreve a aplicação de uma atividade na qual os estudantes foram incentivados a refletir e avaliar as implicações ambientais, sociais e éticas decorrentes da implantação de uma indústria siderúrgica, conforme evidenciado pelo trecho abaixo.

P2: (...) fiz essa discussão aqui faz pouco tempo (...) a proposta é assim vai ser construído na:: na região do Pantanal (...) uma siderúrgica pra extração de ferro e de mais algu/acho que manganês né? e as pessoas que moram lá estão preocupadas e tal com o risco daquela indústria eles vão perder uma série de/de:: vai perder ali o habitat de algumas espécies e tudo o mais mas assim o maior problema deles não era nem perder o habitat de 
espécies mas assim... será que eu não vou sofrer alguma consequência éh:.: dessa siderúrgica aqui? então eles decidem a população aí é onde eu entro né? eu decido trabalhar com os meus meninos os meus alunos como sendo eles moradores do Pantanal... né?

(...)

P2: então para isso eu tenho que contextualizar... como é que o Pantanal? o que tem no Pantanal? como é o solo? como é a vegetação? como é que são os animais? qual é o período de chuvas e tudo o mais? como é que são as pessoas e tal?

(...)

e a proposta da atividade que é da própria proposta é é curricular... éh:: é que os alunos façam uma carta né? para o IBAMA pedindo uma:: que eles verifiquem a situação e aí entra as questões éticas também então isso daqui que acontece aqui

Embora a atividade citada pela docente $\mathrm{P} 2$ tenha sido desenvolvida no sétimo ano do ensino fundamental e, por isso, tenha como foco questões mais pertinentes a biologia, as falas indicam um trabalho mais aprofundado envolvendo assuntos ambientais, no qual os estudantes são incentivados a refletir acerca de vários aspectos envolvidos no problema proposto.

Por fim, ainda outros assuntos relacionados ao tema foram citados pelas docentes P2, P4 e P5, como mostram os trechos a seguir, retirados das transcrições.

P2: (...) eu tô ensinando/tô falando lá de petróleo - - dei o exemplo lá - - se não houver uma discussão por exemplo do pré-sal (...) ninguém vem aqui para bater palma... achar bonitinho... tem um interesse... ninguém vem aqui oferecer tecnologia de ponta se não tem um interesse... imagina... que que tá movendo tudo isso né? (...)

$----$

Hirayama: (...) é uma situação do caderno do Estado (...) sobre o estudo da síntese... e da produção industrial da amônia... a partir dos gases nitrogênio e hidrogênio... (...) o que você acha dessa atividade? você costuma dar?

P5: (...) primeiro eu falei sobre... como obtenção dos gases... aí eu contei uma parte da história... né? de história mesmo da época da Segunda Gue::rra do problema de chegar (...)

P5: (...) nós falamos né? sobre:: o:: tudo... é porque tinha que sair do Chi::le... a dificuldade que estava na época (...)

----

P4: (...) eu conto (...) eles não estavam só preocupados só com nitrato para... alimentação das pessoas e fertilizante (...) isso é para fazer... fazer pólvora... né? na época da guerra eu falo nitrato é para fazer guerra para fazer pólvora (...)

Nas falas acima, ainda que não tenham detalhado como desenvolveram as atividades, as docentes mencionaram a consideração de algumas questões envolvendo a influência do contexto social, político e econômico no desenvolvimento científico e tecnológico. 
P3, ao mencionar a importância de se abordar os modelos com os estudantes, também apontou que busca motivar os estudantes a refletir acerca das relações entre a sociedade e o desenvolvimento científico em determinado período histórico.

P3: (...) as vezes eu falo... eu desisti "mil oitocentos e oito é uma data importante na história do Brasil alguém sabe alguma?" "ahn? quê?" "ah a chegada da família real" "isso tem alguma mudança na ciência... para gente? na vida da gente?" "ahn?" "está bom... deixa passa... quem quiser pesquisa" aí volto pra minha aula

No que tange às práticas descritas pelos sujeitos entrevistados, um dos principais pontos a se destacar é que, apesar deles, em certa medida, já realizarem discussões acerca das inter-relações entre a química e a sociedade, as abordagens citadas não envolvem a problematização acerca da natureza tecnocientífica da química.

De acordo com Sjöström e Talanquer (2014), tal característica favorece, no ensino de química, o desenvolvimento de discussões e reflexões acerca das complexas interações que ocorrem entre química, tecnologia, sociedade e meio ambiente. Os autores consideram que abordagens educacionais orientadas à compreensão e problematização de ideias e práticas científicas, bem como as que permitem a tomada de decisão crítica e consciente acerca de assuntos envolvendo o desenvolvimento químico e tecnológico, representam o nível mais elevado de complexidade da dimensão humanística na educação química, o qual eles denominaram como "química crítico-reflexiva". Nesse sentido, somente as considerações mencionadas por P2 (a respeito da importância de se analisar com os estudantes as motivações políticas e econômicas envolvidas no desenvolvimento da tecnologia de extração do petróleo da camada pré-sal) e por P5 (sobre o trabalho com os múltiplos fatores que influenciaram o desenvolvimento do processo HaberBosch de produção de amônia), podem, se trabalhadas de modo abrangente, promover uma discussão mais prolífica acerca das relações entre a pesquisa química básica e a aplicada, assim como acerca do papel da química na sociedade.

\subsubsection{Relevância}


Todos os sujeitos entrevistados se referiram às discussões acerca do tema como importantes ou interessantes. De acordo com P1, a consideração dos assuntos sugeridos durante a entrevista seria relevante apenas para os estudantes da escola técnica onde ele atua, pois estes estariam mais preparados para realizálas do que os alunos da rede estadual. Contudo, o docente não menciona como a abordagem dos múltiplos contextos associados ao conhecimento químico poderia contribuir para a formação dos técnicos em química.

Conforme mostra o trecho a seguir, P5 considera interessante abordar 0 papel da amônia na sociedade e as consequências decorrentes do uso de fertilizantes. Segundo a professora, esses assuntos servem como fonte de informações, as quais permitem aos estudantes perceber a presença dos conhecimentos químicos em seu cotidiano e, consequentemente, ampliar sua concepção sobre a química.

Hirayama: (...) discutir as seguintes questões né? (...) apontar uso da amônia como matéria prima pra obtenção de vários materiais né?

(...)

Hirayama: (...) principalmente para agricultura moderna (...) a importância para o país... né? ou para o mundo da autossuficiência da produção de amônia... depois discutir problemas ambientais decorrentes da utilização intensiva de fertilizantes químicos e o risco pra saúde da população pelo uso de agrotóxicos (...) você você faria essas discussões ou

P5: faria...

Hirayama: (...) você acha que são interessantes?

P5: não... são interessantes (...) eu discutiria sim... (...)

Hirayama: por que você acha que é interessante para o... estudante? (...)

P5: informação... no caso... eu eu eu gosto que.: eles tenham assim... uma informação de tudo que está acontecendo... na química (...) eu gosto de assuntos assim... assuntos interessantes... que... para mostrar que química não é só $\mathrm{H}_{2} \mathrm{O}$ mais isso e aquilo... que ele também é um monte de assunto interessante que está acontecendo ao redor do aluno

A necessidade de os alunos identificarem a presença do conhecimento químico em diferentes âmbitos e setores da cultura humana contemporânea tem sido ressaltada em documentos curriculares oficiais para a educação química (Brasil, 2002; Brasil, 2006). Promover o desenvolvimento dessa capacidade requer a superação de um ensino descontextualizado, centrado na transmissão de fatos isolados e a inclusão de elementos da HFC na prática docente. Contudo, tal trabalho - mais do que informar os estudantes acerca da ciência presente em assuntos cotidianos - envolve problematizar as relações estabelecidas entre a química, a tecnologia e a sociedade (Talanquer, 2013). 
Nesse sentido, a consideração dos múltiplos contextos que afetam o desenvolvimento científico e tecnológico - além de mostrar que a química não se restringe a um conjunto de fórmulas, equações e nomes - contribui para a compreensão do conteúdo de textos e comunicações sobre temas envolvendo conhecimentos e práticas químicas, veiculados por diferentes meios de comunicação (Brasil, 2006).

P4, em consonância com essa recomendação, apontou que discussões envolvendo química, indústria e tecnologia são importantes para que os estudantes compreendam minimamente questões relativas à ciência com as quais se deparam no seu cotidiano e, assim, comecem a se questionar acerca do mundo e das consequências das ações humanas.

Hirayama: (...) no caso dessas discussões (...) sobre... essa relação entre a química indústria e tecnologia né? éh:: também o foco nas questões ambientais e éticas (...)

P4: (...) isso é superimportante sim (...)

Hirayama: por que você acha que é importante eles terem essa... essa... essas discussões?

P4: porque eles vivem numa redoma eles não tem a menor noção de/do/do mundo lá fora né? então eles... e eles não estão acostumados a questionar nada... eles... pegam... é como se fosse um lanche pronto que chega e é só pegar o lanche e ingerir então... essa coisa de que... dá certo não dá certo tentativa e erro é melhor assim ou as consequências das ações... eles já têm que comecar a ver né? por exemplo... todo mundo tem um mínimo de entendimento da/da crise de água mas é uma coisa que afeta todo mundo então o tempo todo eles estão sendo bombardeados com essas noções (...)

Assim como P4, P2 também aponta a relevância de promover a participação dos estudantes em discussões sobre as inter-relações entre ciência, tecnologia e sociedade, pois, de acordo com a docente, eles possuem uma concepção estreita a respeito desse assunto.

\footnotetext{
Hirayama: (...) comentar com os alunos a importância do Kirchenbauer né?

(...)

Hirayama: ou... dependendo da turma aqui a outra sugestão é trabalhar essa/esse texto do Hoffman né? na verdade essa frase do Hoffman que também fala sobre... a relação entre... a síntese né? na indústria e a parte acadêmica (...)

(...)

Hirayama: (...) você acha que é interessante para os estudantes (...)

P2: (...) eu complementaria uma coisa assim ó "discutir com os alunos a interdependência entre ciência e tecnologia"... eu ainda colocaria ciência tecnologia E sociedade... né? porque não... é é para mim é uma tríade não tem como você dissociar uma coisa:: da outra (...) quando a gente começa... éh::: conversar com os meninos seja do ensino médio seja do fundamental quando você fala de ciência...né? - - não importa se química biologia física não importa - - ... para eles ciência é muito relacionada à área de saúde só... né? e tecnologia é como se fosse relacionado por exemplo a parte assim de computador... de coisas mais...
} 
quando fala de tecnologia é como se fossem só esses/esses pequenos aparelhos né?

Ainda, segundo P2, a consideração de assuntos que favoreçam o estabelecimento de relações entre os conhecimentos da química e os de disciplinas da área de humanidades, tais como sociologia e história, é importante para dar sentido à química e promover uma compreensão mais abrangente acerca dela.

Hirayama: (...) por que havia um grande interesse da Alemanha né? na produção da amônia no início do século vinte e aí o professor fornece aos alunos mais informações sobre aquele contexto que existia na época

(...)

Hirayama: e discute as demandas

(...)

Hirayama: você acha interessante nesse caso fazer ess/esse tipo de discussão?

P2: eu acho mas éh::.: eu ainda acho que qualquer assunto não só esse como por exemplo... você citou do petróleo agora né? que:: ele tivesse uma relação uma interdisciplinaridade com o professor de sociologia de história... porque eu acho que daria até sentido... porque assim... éh::.: não que a gente tenha que desviar o foco né? mas assim a química se ela não tiver associada à outra área parece que é uma coisa só técnica... né?

Sjöström e Talanquer (2014) enfatizam que a caracterização da química como tecnociência, orientada tanto por objetivos científicos quanto tecnológicos, favorece discussões sobre as inter-relações entre química, tecnologia, sociedade e ambiente, com base em perspectivas históricas, sociológicas e filosóficas. Logo, a introdução no ensino de química de temas que propiciem a abordagem de questões humanísticas, como defende P2, pode contribuir para que os estudantes desenvolvam uma concepção mais crítica sobre as práticas e conhecimentos químicos.

Ainda, no que tange a natureza dual - científica e tecnológica - da química, Ribeiro (2014) considera que o conceito de tecnociência se refere a uma forma diferente de produção de conhecimento que desconstrói a "imagem de ciência pura, neutra e desinteressada, autônoma e puramente cognitiva" (p. 292). Lopes (1999) aponta que, embora transmitida por cientistas e professores como uma atividade destituída de interesses, a ciência é uma produção social "sujeita aos processos de divisão social do conhecimento, às lutas pelo lucro, aos conflitos e às disputas por poder das demais instituições sociais" (p.116). Cachapuz et al. (2005) ponderam que é fundamental se superar na educação científica uma visão descontextualizada sobre a ciência, a qual desconsidera os múltiplos impactos decorrentes da atividade 
científica e tecnológica, bem como os interesses que influenciam o seu desenvolvimento.

Desse modo, como aponta P3 no trecho abaixo, abordar os diversos fatores que impulsionam o desenvolvimento científico e tecnológico pode ampliar a compreensão dos estudantes a respeito da química, mostrando que, como outras atividades humanas, ela também é influenciada por interesses econômicos e políticos.

Hirayama: (...) a proposta de discussão é (...) "por que havia um grande interesse da Alemanha na produção da amônia no início século vinte" né? e depois... a sugestão é fornecer aos alunos mais informações sobre o contexto político e econômico da Europa da época

(...)

Hirayama: você acha importante?

P3: eu acho importante

Hirayama: por que (...)

P3: para eles entenderem que a química não é algo... aliás... nada é isolado né? não existe um fato isolado... uma descoberta não vem porque o cara está interessado em química porque está interessado em material porque tem todo um contexto político social histórico que envolve essas... essas observações e esses interesses né? ninguém é movido ao interesse plenamente puramente para uma única questão (...) então assim eu acho que nenhuma ação da gente é isolada... e os contextos... essa contextualização eu acho bacana acho interessante fazer

Ainda com relação à química como prática tecnológica, Vesterinen, Aksela e Sundberg (2009) defendem que

O mito de que a tecnologia e a ciência são neutras, isentas de valores, e objetivas, e que a perícia técnica pode resolver qualquer problema, pode ser enfrentado por meio da discussão das possíveis consequências da aplicação de ideias científicas, incluindo as noções de risco e de avaliação dos benefícios (p.208).

Em alguma medida, as considerações de P2, evidenciadas nas falas a seguir, estão em consonância com as considerações realizadas por esses educadores. Para ela, é importante que a abordagem de questões sobre a química e sociedade promova a conscientização dos estudantes sobre os benefícios oriundos do desenvolvimento químico e tecnológico e também acerca da responsabilidade humana para com o meio ambiente.

Hirayama: isso você acha que é importante (...) para quê assim? qual seria o principal objetivo? (...)

P2: (...) eu acho que ele tem ele tem que se aperceber que ele é o... - - não é que é o 
produto final - - mas essa ciência essa tecnologia tem que servir para essa sociedade né? mas quando eu falo servir não é que o homem tenha que ser sabe? o... ser:: antropocêntrico não isso... né? mas que ele saiba assim que ele pode fazer com que essas... essas... que a ciência e a tecnologia sirva para ele... mas que ele tem que retribuir também para 0 ambiente

Hirayama: entendi

P2: o ambiente que ele vive então é de responsabilidade dele também manter toda essa... tudo que o cerca né? (...)

Assim, para a maioria dos sujeitos entrevistados, discutir acerca das interrelações entre ciência, tecnologia, sociedade e ambiente em sala de aula é importante, pois promove uma compreensão mais abrangente acerca da química, dos contextos que influenciam suas práticas e o seu desenvolvimento, e das questões sociais e ambientais envolvidas, assim como contribui para conscientizar os estudantes a respeito dos múltiplos impactos oriundos do desenvolvimento químico. Como visto anteriormente, a relevância de se fomentar tais habilidades, conhecimentos, capacidades e valores também é enfatizada em documentos curriculares oficiais e em pesquisas da área de ensino de ciências.

Entretanto, embora a abordagem de tais conteúdos seja favorecida pela própria natureza tecnocientífica da química, os docentes entrevistados não apontaram diretamente a importância de se compreender tal característica, e tampouco a utilizaram para justificar a inclusão de questões envolvendo as relações entre química e sociedade no ensino.

De acordo com Talanquer (2013), uma educação que reconheça o caráter tecnológico da química não somente promove o uso de conhecimentos químicos para descrever e explicar problemas de relevância social, econômica e ambiental, como também fornece aos estudantes a oportunidade de analisar, discutir e praticar "os modos de pensar e agir que tem feito da química uma disciplina tão transformadora" (p. 1766). Vesterinen, Aksela e Sundberg (2009) apontam ainda que a reflexão crítica sobre o papel da química na sociedade, bem como acerca das questões éticas e sociais envolvidas, tendo por base a relação simbiótica que a disciplina estabelece com a indústria e a tecnologia, favorece a formação de estudantes alfabetizados científica e tecnologicamente.

Assim, torna-se importante analisar a questão: por quais motivos os docentes consideram importante desenvolver nos estudantes as habilidades, os conhecimentos, as capacidades e os valores por eles apontados? Tal questão é 
importante, pois se relaciona com a própria função que o professor atribui ao ensino de química.

As falas abaixo evidenciam que, para P5, a principal finalidade de se discutir os fatores que influenciaram o desenvolvimento do processo Haber-Bosch é motivar os estudantes a aprender mais acerca dos conteúdos disciplinares a serem abordados.

Hirayama: (...) e eu queria saber o que você pensa sobre essa discussão... né? se você acha ela interessante... essa aqui...

P5: (...) então eu acho muito interessante... isso aí tem que ser dado tem que ser falado sim... para ele ter interesse

A atenção dispensada pela professora a essa questão é importante, tendo em vista o pouco interesse dos alunos pela ciência e o seu estudo, assim como o papel de discussões sobre a ciência no enfrentamento desse desafio (Dibattista e Morgese, 2012; Corrêa, 2009; Osborne, 2007; McComas, Almazroa \& Clough, 1998). Pesquisas em educação apontam que considerar aspectos contextuais e promover concepções mais adequadas acerca da ciência e do trabalho dos cientistas podem aumentar o interesse e a motivação dos estudantes por ciências (King, 2012; Solbes e Traver, 2003). Hoffman (2007) defende que a química é interessante não apenas para os químicos, mas para todas as pessoas. Segundo ele, tal interesse resulta das dualidades inerentes ao conhecimento e práticas químicas, tais como a síntese/análise e utilidade/nocividade. Desse modo, abordagens didáticas - como a discussão sobre as relações entre química e sociedade - que favoreçam a reflexão sobre essas polaridades poderiam contribuir para suscitar o interesse dos alunos pelo estudo da química.

Se, por um lado, os contextos associados à química podem tornar o seu ensino mais atraente, por outro, abordá-los exclusivamente para suscitar o interesse dos estudantes pelos temas trabalhados restringe sobremaneira o potencial da inclusão dessas questões no ensino. Isso porque, nesse caso, assim que o intento de motivar os estudantes é atingido, os assuntos trabalhados inicialmente deixam de ter relevância, o que, consequentemente, pode levar o docente a desconsiderar discussões envolvendo as inter-relações entre química, sociedade, tecnologia e ambiente que contribuem para a formação integral dos estudantes. 
Segundo P3, discutir a relação entre pesquisa básica e aplicada, como também a interdependência entre química e tecnologia é importante para que os estudantes, por meio da compreensão dessas relações, desenvolvam a autonomia na busca do conhecimento.

Hirayama: (...) você faria uma atividade dessa com alguma turma que você tem ou não?
P3: faria... hoje agora? faria
(...)
Hirayama: e você faria por quê? você faria... por quê?
P3: (...) porque o mais importante para mim é eles compreenderem todas essas relações e
se eles têm uma boa compreensão... éh:. e uma boa leitura... aí é o que eu digo para você...
se eu tivesse aluno de verdade que tem boa leitura boa compreensão da correlação disso
com tudo no mundo... - - apesar da gente seccionar né?... porque eu estou dando aula de
QUímica...- - mas ele tem que entender que está tudo misturado... se ele tivesse essa
compreensão ele no dia que ele quisesse pegava o livro e ia sozinho entendeu?

Ainda, ao se referir as questões abordando os fatores que influenciaram 0 desenvolvimento do processo Haber-Bosch, P3 defendeu que compreender os interesses envolvidos na ciência e tecnologia também favorece a autonomia dos estudantes.

Hirayama: e qual o grau de importância que você atribuiria a (...) esse tipo de atividade? (...)

P3: para mim é a questão da pesquisa... acho que... acho que o problema para mim... $\underline{a}$ questão aqui para mim não é nem a interdisciplinaridade é a busca a pesquisa... o saber buscar uma informação... trabalhar essa informação para criar outro conhecimento outro significado entendeu?

Hirayama: a despeito de qual informação que é?

P3: qualquer que seja... eu acho que... e óbvio... fazer essas relações né? eu acho bacana acho importante por isso mais para criar o próprio entendimento das coisas

(...)

você falar assim... a importância da amônia porque a importância de não sei o quê da síntese de não sei o quê (...) isso aqui é tudo teórico acho lindo acho incrível acho importante (...) mas eu acho mais importante é fazer esses... esses significados para eles

Uma das principais finalidades do ensino médio, de acordo com a Lei de Diretrizes e Bases da Educação Nacional (1996) é o desenvolvimento do pensamento crítico e da autonomia intelectual do educando. Assim, a importância de os alunos serem estimulados a estudarem e aprenderem, de maneira contínua, é enfatizada também em documentos curriculares oficiais para o ensino médio (Brasil, 1999; 2002; 2006).

Contudo, apesar de defender a importância de se promover a autonomia intelectual dos estudantes, P3 não valoriza o papel dos conhecimentos específicos 
da química na consecução de tal finalidade. Para ele, quaisquer assuntos que possam contribuir para o desenvolvimento dessa capacidade devem ser abordados. No limite, essa perspectiva implica defender que a autonomia dos estudantes poderia ser fomentada a partir de conteúdos oriundos de qualquer área do conhecimento. No entanto, a discussão acerca da função dos conhecimentos no desenvolvimento da autonomia é complexa.

De acordo com Carvalho (1999) a atuação autônoma em determinado campo depende dos conhecimentos que se tem dele. Ele aponta que a autonomia na resolução de problemas de física, por exemplo, está vinculada a utilização adequada da linguagem e dos procedimentos considerados relevantes por essa área ao lidar com questões científicas específicas. Desse modo, é importante refletir acerca do que significa ter como finalidade o desenvolvimento da autonomia no ensino de ciências, em geral, e de química, em particular, bem como acerca da importância dos conhecimentos sobre ciências para se alcançar esse objetivo.

Paula e Lima (2007) relacionam o desenvolvimento da autonomia intelectual com a formação de um sujeito crítico capaz de "superar a tendência da cultura contemporânea de pasteurizar identidades e privatizar os problemas humanos, retirando sua dimensão social e econômica" (p. 7). Nesse sentido, consideram a relevância não apenas da aprendizagem das leis e teorias, mas principalmente de como esses conhecimentos são usados em situações reais e das relações complexas entre ciência, tecnologia e sociedade.

Mais especificamente em relação ao ensino de química, os PCN+ (2002) apontam que os conhecimentos químicos podem ampliar os horizontes culturais e a autonomia no exercício da cidadania. Para isso, indicam que tais conhecimentos devem ser promovidos como meios de interpretar e intervir no mundo, e que a química deve ser abordada como um empreendimento humano, com seus conceitos, métodos e linguagens próprios, associada à tecnologia e à sociedade.

Desse modo, se o que se pretende no ensino de química é desenvolver a autonomia intelectual, de modo a favorecer a atuação crítica em questões relacionadas à química em uma sociedade cada vez mais afetada pelo seu desenvolvimento, é necessário "envolver os alunos nas formas específicas de olhar, analisar e transformar o mundo que são essenciais para a química" (Talanquer, 2013, p. 1766, grifo nosso). Segundo Talanquer, isso envolve, por exemplo, o 
reconhecimento e a análise das implicações sociais e éticas associadas ao desenvolvimento da química.

Para P2, o professor de química deve abordar os fatores que afetam o desenvolvimento científico e tecnológico em função de tais assuntos surgirem nas salas de aulas nas quais há estudantes se preparando para o Exame Nacional do Ensino Médio (ENEM) e exames vestibulares. Ademais, considera que tal abordagem, de algum modo, deve contribuir para a formação de sujeitos capazes de se colocarem diante de questões associadas ao conhecimento químico.

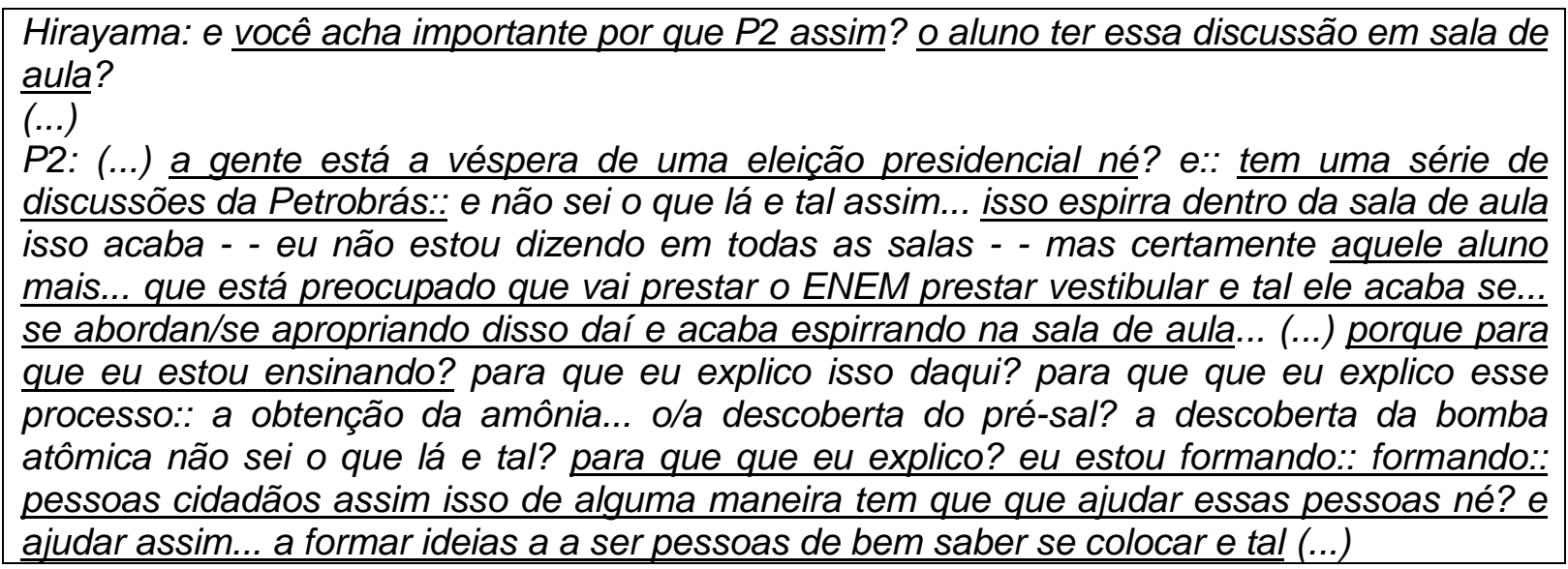

Desse modo, as falas sugerem que, embora tenha como preocupação a preparação dos alunos para os exames vestibulares, a docente também considera a formação para a cidadania como a principal finalidade de ensinar sobre química. Isso fica mais evidente no excerto a seguir, no qual P2 aponta que analisar as implicações éticas e ambientais decorrentes do desenvolvimento da química pode favorecer a tomada de decisões a respeito das questões com as quais os estudantes se deparam em suas vidas.

Hirayama: mas você acha importante ((discussão das implicações éticas))?

P2: eu acho importante... porque na vida inteira eles vão fazer esse tipo de discussão... para ganhar alguma coisa ganhar um... uma habilidade de raciocínio também conhecimento e tal e que ele possa tomar decisões né? possa fazer escolhas e tal... e sempre vai esbarrar em questões éticas pode reparar... né? (...)

A importância das questões que relacionam química e sociedade para formar cidadãos críticos e conscientes é destacada por diversos pesquisadores na área de ensino de ciências, ao se referirem à perspectiva CTSA, bem como em trabalhos que consideram as implicações da filosofia da química para a educação. De acordo 
com Díaz et al. (2003), o estudo das relações entre ciência, tecnologia e sociedade, em todos os sentidos possíveis, favorece o desenvolvimento de conhecimentos, habilidades e atitudes que contribuam para a atuação responsável - individual e coletiva - na sociedade civil e a tomada de decisões fundamentadas, em um mundo cada vez mais afetado pelo desenvolvimento científico e tecnológico. Talanquer (2013) defende que o objetivo do ensino de química deve ser mais do que apenas informar as pessoas, mas contribuir para a formação de cidadãos responsáveis. Para isso, segundo o educador, é importante compreender os modos pelos quais os químicos têm compreendido e transformado o mundo para o benefício da sociedade, bem como as implicações sociais, ambientais e éticas decorrentes do uso e da produção de produtos da química.

Dentre os professores entrevistados, P1 não apontou a finalidade de se abordar tal tema: considerou apenas que outras questões são mais relevantes para a formação dos estudantes. P4, por sua vez, apenas considerou, de modo superficial, que a inclusão das discussões no ensino pode incentivar os estudantes a se questionarem acerca do mundo.

O Quadro 03 a seguir apresenta uma síntese das concepções e práticas dos sujeitos entrevistados no que se refere à abordagem do tema relações com a sociedade. 


\begin{tabular}{|c|c|c|}
\hline Sujeitos & Prática docente & Relevância \\
\hline P2 & $\begin{array}{l}\text { - Trabalha com atividades envolvendo reflexão e avaliação de questões } \\
\text { ambientais, sociais e éticas. (Exemplo: implicações ambientais e sociais } \\
\text { decorrentes da construção de siderúrgica.) } \\
\text { - Considera assuntos que relacionam o contexto social, político e econômico com } \\
\text { questões científicas. (Exemplo: contexto político e econômico envolvendo a } \\
\text { exploração do pré-sal.) }\end{array}$ & $\begin{array}{l}\text { - } \quad \text { Compreender as inter-relações entre ciência, } \\
\text { tecnologia e sociedade. } \\
\text { - } \text { Ampliar concepções sobre ciência e tecnologia. } \\
\text { Dar sentido à química e ampliar a compreensão a seu } \\
\text { respeito. } \\
\text { - Promover a preparação para exames vestibulares e } \\
\text { para o ENEM. } \\
\text { Promover a responsabilidade para com o meio } \\
\text { ambiente e a compreensão do papel da tecnologia na } \\
\text { sociedade. } \\
\text { - Favorecer a tomada de decisões acerca de questões } \\
\text { científicas e tecnológicas. } \\
\text { Desenvolver habilidades de raciocínio. }\end{array}$ \\
\hline P3 & $\begin{array}{l}\text { - Utiliza questões motivadoras sobre temas geradores e acerca das relações entre } \\
\text { a sociedade e a ciência, em determinado período histórico, sem aprofundamento } \\
\text { de tais assuntos. (Exemplo: Alimentos como tema gerador.) }\end{array}$ & $\begin{array}{l}\text { - Compreender relações entre ciência e sociedade, } \\
\text { assim como os diversos fatores que influenciam a } \\
\text { ciência e a tecnologia. } \\
\text { Desenvolver autonomia e estimular a busca por } \\
\text { informações. }\end{array}$ \\
\hline P5 & $\begin{array}{l}\text { - Fornece exemplos de aplicações e processos (Exemplo: velocidade das reações } \\
\text { na indústria para ilustrar conteúdo de cinética química.) } \\
\text { - Considera alguns assuntos que relacionam o contexto social, político e } \\
\text { econômico com questões científicas em determinada época. (Exemplo: } \\
\text { importância do processo de fabricação de amônia dentro de um contexto } \\
\text { histórico.) } \\
\text { - Menciona alguns problemas ambientais e os aborda esporadicamente em } \\
\text { eventos informais (Exemplo: descarte inadequado de resíduos.) }\end{array}$ & $\begin{array}{l}\text { Ampliar a compreensão sobre a química. } \\
\text { Motivar os estudantes a estudar química. }\end{array}$ \\
\hline
\end{tabular}

Quadro 03: Quadro-resumo das concepções e práticas dos sujeitos entrevistados acerca do tema Relações com a sociedade. 
3.1.2. Modelos e modelagem

\subsubsection{Prática docente}

Quando questionados sobre como abordam os modelos científicos em sua prática pedagógica, os sujeitos entrevistados se referiram, sobretudo, à consideração de alguns modelos atômicos desenvolvidos no decorrer da história, os quais têm sido comumente estudados nos anos finais do ensino fundamental e no primeiro ano do ensino médio.

Conforme sugerem as falas abaixo, P1 relacionou a consideração de modelos no ensino de química com a apresentação dos modelos atômicos de Dalton e Rutherford; enquanto P5 mencionou a abordagem de alguns aspectos conceituais associados aos modelos históricos.

Hirayama: você consegue falar sobre isso lá ((na escola estadual))?

P1: modelo? SIM... poderia falar no (...) átomo de Dalton e depois vai desenvolvendo falar em Rutherford

----

P5: (...) com o Dalton eles nem ligam muito... nem Thomson... mas na hora que eu começo a falar sobre o Rutherford e Bohr eles nem pis-cam (...) falo no final do Bohr... dos elétrons pularem de camada... aí eu dou o exemplo da tomada e explico porque a energia do fio de cabelo não é o mesmo que lá

Segundo os Parâmetros Curriculares Nacionais para o Ensino Médio PCNEM (Brasil, 1999), a identificação dos principais modelos elaborados para explicar a constituição dos materiais, em diferentes épocas, é uma das habilidades a serem desenvolvidas pelos estudantes na disciplina de química. Logo, a abordagem das principais características dos modelos atômicos de Dalton, Thomson, Rutherford e Bohr seria um aspecto pertinente ao ensino de modelos. Contudo, a mera consideração de tópicos conceituais e a ênfase na transmissão dos conteúdos dos modelos estudados limita a compreensão mais abrangente acerca do desenvolvimento das ideias científicas (Justi e Gilbert, 2000). De acordo com Justi (2010), além de adquirir conhecimentos declarativos e informações conceituais sobre os modelos, os estudantes devem compreender de que modo eles foram construídos. 
No que tange a essa questão, os trechos a seguir sugerem que, em certa medida, os docentes P2, P4 e P5 chamam a atenção dos estudantes para alguns aspectos relativos à elaboração dos modelos atômicos históricos.

P5: (...) mostro:: como Dalton... viu:: fez a teoria... e como ele... a diferenca no final... a diferença de como seria uma fórmula de uma substância para Dalton e uma substância para que eles veem hoje... então como é que foi aquele modelo de antes para o modelo de hoje... é assim que eu abordo essa parte (...)

----

P5: (...) Rutherford e Bohr... aí eu falo que é na/não... ele não espera::va (...) falo qual era a intencão que ele tinha... né? o que ele queria fazer... e como ele se programou e porquê que deu tudo diferente do que ele imaginava... mas eu não falo de divergências assim... da época...

Além de abordar os conteúdos dos principais modelos atômicos, P5 busca, até certo ponto, comentar com os estudantes quais as motivações e os objetivos dos cientistas ao trabalhar com as questões que levaram à construção dos modelos. Contudo, a docente parece desconsiderar outras características importantes relacionadas a esse processo, como a colaboração entre os cientistas e os debates e divergências ocorridos na época.

P2, por sua vez, conforme sugerem as falas abaixo, aponta a importância de mostrar aos alunos que a elaboração dos modelos é resultado do trabalho de vários cientistas. Porém, evidenciou uma visão estreita acerca das motivações envolvidas na prática científica.

P2: (...) e aí onde eu entro na importância dos modelos dentro da... da nossa área né? e aí... quem criou isso? né? quem pensou nisso? quem é que está por trás disso? né? então assim a importância da academia nessa história... e quando eu falo da academia eu estou me referindo assim a todas as pessoas que de alguma maneira trabalham para que (...) esse nosso dia a dia aconteça né? então é importante o papel do cientista nessa hora? é... então ele não é aquele bicho louco que fica trancado no laboratório... não... ele está pensando em facilitar a vida... a vida de alguém né? (...)

Ainda que a proposição de modelos tenha, muitas vezes, o intuito de promover a compreensão sobre determinados aspectos de um estudo, tal processo abrange outros interesses, tais como a busca pelo poder, a satisfação pessoal ou mesmo a resolução de questões ainda não esclarecidas acerca da Natureza.

P4, ao comentar como procura abordar os modelos em sua prática, fez referência ao experimento de espalhamento de partículas alfa, realizado por Geiger 
e Marsden, o qual contribuiu para que Rutherford, posteriormente, propusesse seu modelo atômico.

Hirayama: (...) essa questão de modelos você costuma abordar os modelos?

P4: (...) eu passei (...) eu tenho DVD que eu comprei da... grandes descobertas da ciência (...) mostra:: bem... tem inclusive... aquela... o segundo ano que fala como que foi $\underline{a}$ descoberta do próton aquela (experiência) do:.: da folha de ouro... tem aquilo... em desenho animado direitinho em detalhes

A apresentação do desenvolvimento histórico de modelos atômicos, acompanhada pela descrição dos aparelhos e conceitos envolvidos nos experimentos que contribuíram para os cientistas elaborarem suas ideias acerca da constituição da matéria, é comum nos livros didáticos de química, os quais influenciam sobremaneira a prática dos professores (Melo, 2002). Embora a abordagem desses assuntos tenha o potencial de contribuir para que os estudantes compreendam o papel dos experimentos, das hipóteses e da cooperação entre os cientistas na construção dos conhecimentos científicos, a ênfase nos aspectos conceituais relacionados às atividades experimentais envolvidas na elaboração das ideias científicas pode dificultar tal entendimento.

De acordo com Justi e Gilbert (2000), é importante que as informações acerca dos experimentos históricos estejam relacionadas com as características do modelo anterior na sequência histórica. Como exemplo, apontam que a discussão sobre o experimento de espalhamento de partículas alfa deve ser realizada com base no modelo de Thomson. A esse respeito, Melo (2002) ressalta que tal abordagem histórica precisa envolver discussões acerca das necessidades que levaram ao desenvolvimento de novos modelos. Desse modo, a mera apresentação dos modelos atômicos, sem a devida discussão acerca de sua abrangência e de seus limites, contribui para a disseminação de concepções equivocadas acerca do desenvolvimento da ciência.

No que diz respeito a tais considerações, as falas abaixo sugerem que P5 busca considerar com os estudantes as diferenças entre os modelos atômicos históricos, enquanto P3 aborda as limitações do modelo de Dalton.

P5: é... eu vou mostrando como que era... onde está focado a diferença de um para o outro (...)

P3: (...) a gente trabalha com modelo de Dalton... diz "olha esse não é o último modelo esse 
modelo não explica tudo mas ele serve aqui... existe outro" (...)

Erduran (2001), ao analisar os problemas comumente encontrados no ensino de modelos na disciplina de química, aponta que, geralmente, os materiais didáticos e, consequentemente, alguns professores não explicam quando e por quais motivos um novo modelo é utilizado, não explicitam a diferença entre os modelos estudados e, frequentemente, apresentam modelos híbridos. Segundo Justi (2010), discutir as diferenças entre os modelos atômicos, e suas limitações, pode evitar que os estudantes considerem modelos distintos como se fossem um único, bem como contribui para que entendam os motivos pelos quais uma dada entidade pode ser representada de diversas maneiras. A esse respeito, os $\mathrm{PCN}_{+}$(Brasil, 2002) enfatizam a importância de o aluno

reconhecer, nas limitações de um modelo explicativo, a necessidade de alterá-lo; por exemplo, perceber até onde o modelo de Rutherford foi suficiente e por quais razões precisou dar lugar a outra imagem de átomo (p.91).

Em vista disso, é importante que a abordagem dos aspectos conceituais e do processo de elaboração dos modelos esteja relacionada com a discussão acerca das funções dos modelos no desenvolvimento científico e tecnológico. As falas abaixo indicam que P2, P3 e P4 se preocupam em considerar esses pontos em sala de aula.

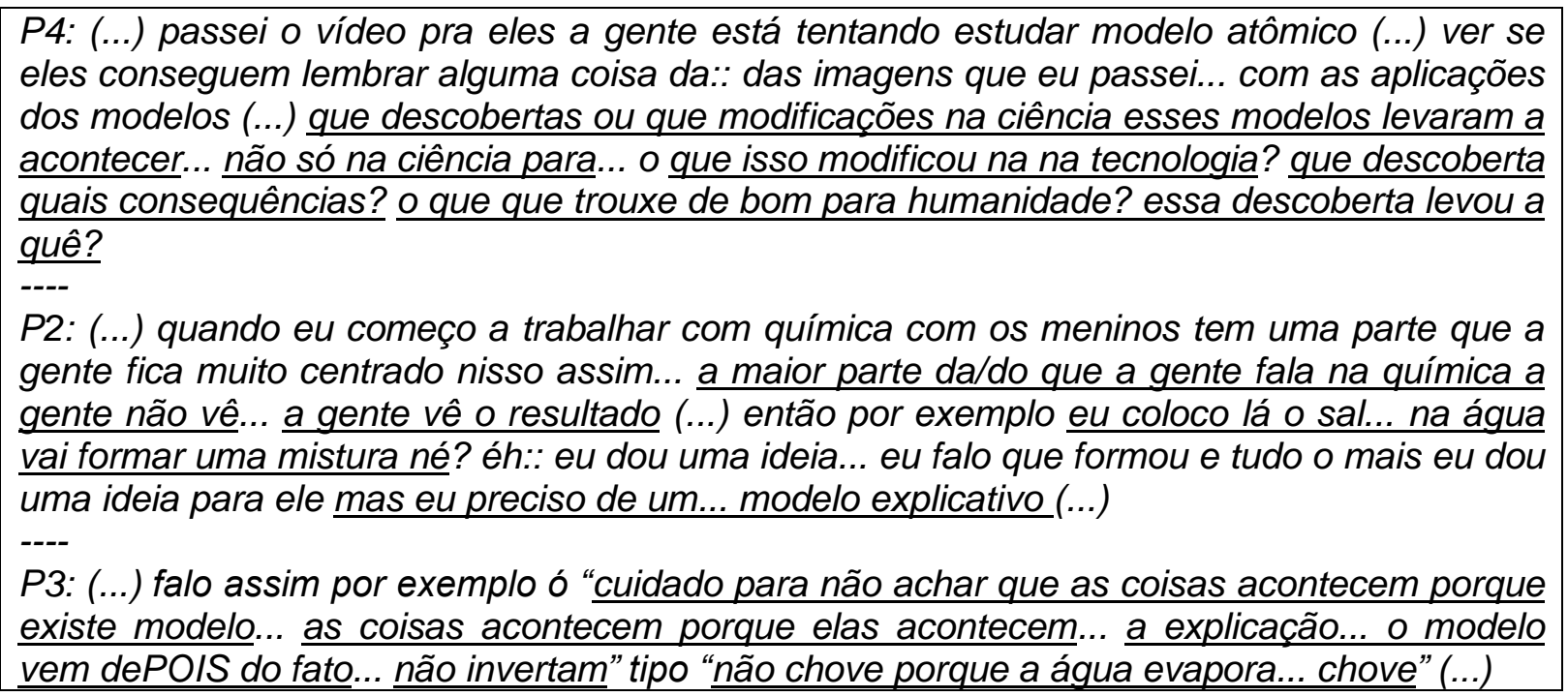


P4 apontou que busca mostrar aos estudantes como a elaboração dos modelos atômicos contribuiu para o desenvolvimento científico e tecnológico. P2 e P3, por sua vez, enfatizaram a importância de se abordar o papel explicativo dos modelos na ciência.

De acordo com Justi (2010), em função dos livros didáticos e de muitos professores apresentarem modelos de ensino como reais e factuais, é comum os estudantes não distinguirem entre os modelos e a realidade. Por isso, a ênfase na natureza das representações apresentadas em sala de aula pode contribuir para a superação de visões inadequadas acerca do conhecimento científico, assim como permitir que os alunos compreendam os modelos como representações parciais, as quais não são a realidade, tampouco cópias fiéis dela.

Nesse sentido, os aspectos apontados por P2 e P3 na fala a seguir são fundamentais para a abordagem dos modelos no ensino de química.

P3: (...) aí eu ponho a equação... e eu apresento os modelos - - mesmo sem falar por exemplo primeiro ano não (estou) trabalhando equação - - ... "tenho aqui uma equação química que é o modelo de expressar o quê? isso aqui é um TEXTO... para ser lido..." (...) -----

P2: (...) eu digo assim (...) vamos pegar o modelo atômico né? a gente nunca viu um átomo... né? e.: outras coisas também a gente não tem ideia muito bem assim... no entanto a gente cria modelos explicativos né? (...) eles dão conta (...) de dar informação de.: fazer com que você se situe que... que entenda um... um processo alguma coisa e tal... uma equação química... não deixa de ser um modelo também explicativo... uma forma representativa né? ilustrativa de você demonstrar que está acontecendo uma uma transformação (...) essa parte de MO-de-los para ciência ela é extremamente importante (...) quando eu faço lá um/faço uma explicação de modelo atômico para os meninos eu deixo muito claro isso é... é uma forma ilustrada... é um/um modelo... é um é uma:: é como alguém pensou que... que seria... né? que seja... para gente poder explicar (...)

Considerar os modelos como uma elaboração humana, sujeita a mudanças e discutir sobre suas funções na ciência, tal como apontam os docentes no trecho acima, contribui para a compreensão da natureza inferencial e criativa da ciência.

Embora tenham destacado o papel explicativo dos modelos científicos, P2 e P3 não fizeram nenhuma menção acerca da função específica que eles desempenham no desenvolvimento do conhecimento químico. Na química, além de servirem como base para a explicação, representação e previsão, os modelos também são utilizados como ferramentas para transformar a realidade. Talanquer (2013) enfatiza a importância dos modelos químicos no teste de ideias, na 
realização de simulações mentais e no papel, assim como na produção de novos materiais que modificam o mundo ao nosso redor.

Outra questão importante no ensino desse tema, citada por P3, é a respeito da provisoriedade dos modelos.

P3: (...) lembro sempre que a ciência éh:: ela não é doutrina religiosa ela... ela muda... é modelo aceito hoje pode não ser amanhã entendeu? mas não aprofundo nessa questão... realmente não aprofundo eu sempre chamo atenção

P3: (...) falo... reflito... falo discuto (...) é um modelo verdadeiro até hoje... verdadeiro sempre entre em aspas...porque pode daqui um tempo mudar... como mudou a língua... faço essas relações... a língua portuguesa passou por uma mudança agora... é regra? é modelo? é verdade? não está verdade até que mude... assim que funciona (...)

A elaboração de modelos na ciência atende a inúmeros objetivos específicos. Porém, eles podem ser modificados quando os conhecimentos acerca da realidade se alteram; as explicações e previsões realizadas com base nos modelos são consideradas inadequadas e novos modos de representação ficam disponíveis (Justi, 2010). Assim, considerar com os estudantes tais questões permite que eles vislumbrem o caráter dinâmico da ciência.

Além de P3, as falas a seguir evidenciam que as docentes P2 e P4 também procuram evidenciar em sala de aula a natureza provisória das teorias e modelos científicos.

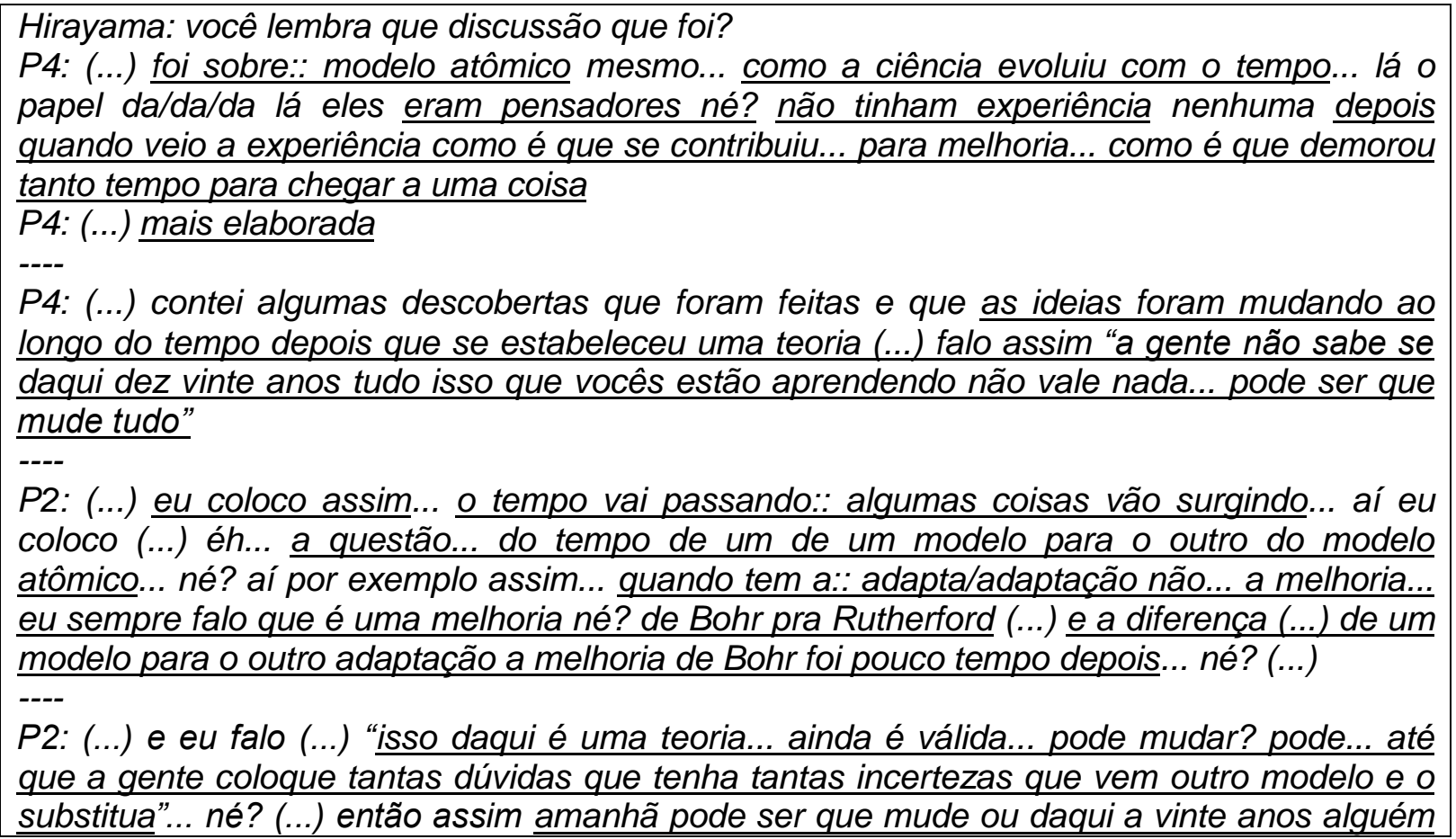


vai estar dando aula e falar a mesma coisa que eu falei né?

Contudo, de acordo com as docentes P2 e P4, os modelos elaborados, no decorrer da história, são substituídos por outros melhores, em decorrência do aprimoramento contínuo da atividade científica. Tomar tal concepção como base para abordar a provisoriedade do conhecimento científico pode transmitir aos estudantes uma visão simplista acerca dos diversos fatores envolvidos na modificação dos modelos, bem como fazer com que eles se questionem a respeito dos motivos pelos quais devem aprender modelos históricos e não somente ideias científicas correntes. Segundo Lombardi e Labarca (2007), um mesmo sistema pode ser modelado de diferentes modos, de acordo com as ideias dos cientistas para cada caso e, portanto, “um dado modelo não pode ser considerado 'melhor' do que outro em sentido absoluto, mas apenas com respeito à perspectiva específica de pesquisa" (p. 189).

A compreensão sobre o desenvolvimento dos modelos envolve também a preparação e organização de situações de aprendizagem nas quais os estudantes possam elaborar, expressar, discutir, utilizar, revisar e reformular os seus próprios modelos (Erduran, 2001; Justi, 2010; Chamizo, 2013). Para Justi (2010), tal processo de modelagem favorece a aprendizagem de conteúdos químicos e o desenvolvimento de habilidades investigativas de visualização. O ensino de química fundamentado em modelagem tem como etapas importantes a elaboração e expressão de um modelo mental com objetivos definidos previamente (Justi, 2010; Chamizo, 2013). Com relação a esse aspecto, é importante que os professores atentem para os modelos elaborados pelos estudantes de modo a compreender suas hipóteses e crenças sobre os fenômenos estudados.

Nesse sentido, as falas a seguir sugerem que P3 busca incentivar os alunos a exporem suas ideias sobre os conteúdos trabalhados.

P3: sim... discutir... mas não apresentar ((os modelos)) para depois da apresentação fazer nunca fiz

Hirayama: entendi... é mais pensar assim no...

P3: pensar sempre... como poderia ser... como vocês acham que está? eu pergunto "como vocês acham que está?"... por exemplo... agora cinética por que nos gases são mais rápidos independente de falar de teoria... da/das colisões... por que nos gases é mais rápido porque eles escutaram na vídeo aula e tem um texto que diz isso... por que é mais rápido? ó... se a gente pensar no que é um gás o que é um gás? qual o modelo que a gente tem? macro e microscópio... como é que pensa? (...) 
No entanto, os questionamentos iniciais realizados pelo docente não são realizados com o objetivo de engajar os alunos em atividades de modelagem, mas sim tem como foco a compreensão das teorias e fenômenos.

P2 descreveu uma aula no ensino fundamental em que incentiva a criação e expressão de modelos explicativos.

Hirayama: (...) você consegue descrever alguma aula que você trabalha esse ou qualquer outro assunto de modelo?

P2: (...) com os pequenos mesmo (...) "olha... eu quero que vocês criem modelos explicativos de cada sistema" (...) éh:: uma menina lá (...) ia representar a ação da bactéria que causa meningite... no sistema nervoso e tudo o mais que que ela fez né? (...) fez a cabeça direitinho e tal e depois ela fez um molde com:: do:: cérebro para encaixar lálá:: no durepox... pegou uma/uma:: cerâmica e tal... fez aquilo lá e o cérebro pra encaixar (...) ela pegou plástico bolha (...) e... envolveu o cérebro né? (...) aí perguntaram "para que serve o plástico bolha? pra proteger e o que a meninge faz? ela protege... ela protege quem? protege o cérebro" e tal né? então ela foi mostrando porquê ela usou aquele material (...)? então assim... ela usou um modelo... um modelo explicativo (...) mas do ensino médio... o ensino médio eu não lembro assim de nenhum modelo não (...) eu acho eu fico mais presa a:: a reações mesmo... mais as coisas de laboratório... eu não... não me lembro de modelos...

P2: (...) e assim... esses modelos eu sempre uso com os meninos do... do fundamental né? assim que eles criem... criem modelos

As falas acima demonstram que a docente considera a criação de modelos como um aspecto importante do ensino de ciências. Contudo, embora o processo de modelagem seja comum entre os químicos, P2 não se recordou de nenhuma aula no ensino médio em que estimulou os estudantes a criar, expressar e testar seus modelos na disciplina de química. Ao mesmo tempo, o exemplo citado sugere que P2 está restringindo sua ideia de modelo explicativo a modelos concretos ou mecânicos.

Ao comentar como desenvolveria uma atividade envolvendo a elaboração de modelos para os compostos iônicos, a professora mencionou que preferiria explicar os fenômenos estudados a incentivar os estudantes a elaborar e testar seus próprios modelos.

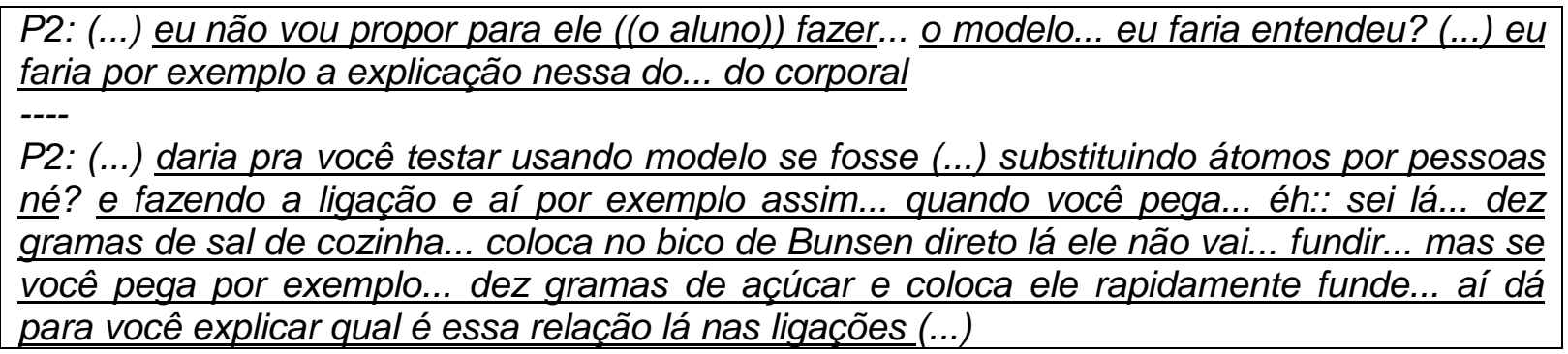


A docente apontou que recorreria à utilização do corpo humano como forma de ilustrar as ligações entre as partículas e explicar os conceitos de interações intermoleculares, conforme evidencia o trecho a seguir.

\begin{tabular}{l} 
P2: (...) imagine eu e você nós dois aqui dois átomos né? e a gente tem uma ligação aqui... \\
né? então eu boto os meninos para darem os bracinhos assim \\
(...) \\
P2: então esse átomo está ligado com ele... "segura firme aí que a tua ligação é TAL porque \\
tem que ter enerGIA não sei mais o que e tal" então eles ficam lá... né? (...) aí eu mostro a \\
garrafa de água para eles "ó aqui dentro da garrafa de água... não tem uma molécula só... \\
tem milhões né? então é uma molécula uma do lado da outra certo? certo... então tem um \\
\hline parzinho aqui mas tem outro parzinho aqui" aí eu boto outro/outra dupla aqui também \\
daquela molécula lá para representar (...) aí eu entro nas questões o que são essas forças \\
intermoleculares... aí por exemplo... eu estou aqui eu e você... e a molécula está ali então \\
esse meu bracinho aqui vai unir com aquela lá então essa minha força com aquela lá essa \\
de aproximação é a força intermolecular quando vai mudar uma substância vai mudar de \\
\hline estado físico né? ela não vai romper aqui... na ligação... ela vai romper aqui entre uma \\
molécula e outra... né? por quê? aí começa a discussão né? aí eles começam assim... \\
\hline (...) \\
P2: (...) aí ele começa "por que não aqui? por que não vai acontecer a quebra aqui? ah \\
porque se acontecer a quebra aqui não vai ser uma mudança física vai ser uma mudança... \\
é uma mudança química professora? é uma mudança química que vai liberar esse átomo e \\
esse outro aqui também aí eles vão ficar sozinhos? não pode" aí volta lá na regra do octeto \\
e tudo o mais... então assim... é um modelo representativo... não aqui concreto mas assim \\
eu interagindo como se fosse um teatrinho... né (...)
\end{tabular}

Segundo Pereira (2013), a utilização do corpo na representação de fenômenos estudados nas aulas de química pode contribuir para promover a interação entre os alunos e a reflexão sobre os aspectos microscópicos relacionados aos modelos, bem como permite que o professor identifique as concepções prévias dos estudantes a respeito dos conteúdos trabalhados em sala de aula. Contudo, para que esses objetivos sejam alcançados é imprescindível a participação ativa dos estudantes na proposição de representações gestuais para os fenômenos, o que não ocorreu na atividade descrita pela docente P2. Ademais, Pereira (2013) considera que é fundamental a discussão sobre as funções e os limites dessas representações para se evitar que os estudantes desenvolvam concepções animistas e se apoiem nelas para explicar os fenômenos.

Desse modo, embora no ensino fundamental prepare atividades nas quais os alunos têm a oportunidade de elaborar seus modelos e utilizá-los para explicar os fenômenos estudados, no nível médio na disciplina de química, P2 tem como principal foco a abordagem de questões conceituais relacionadas ao ensino de modelos. 
A docente P5 descreveu uma prática na qual incentivou os estudantes a utilizar indicadores para classificar alguns materiais em ácidos e básicos.

P5: (...) eles vão trazer:: sabão... cândida... tudo... e todos os grupos fazem uma única amostra para todos então eles têm que construir uma tabela... eles têm que separar os indicadores... as cores... eles fazem uma construção e no final... a minha pergunta do final é... depois de tudo que ele fez... ele vai ter que me mostrar... por exemplo... índice de naftalina... na substância... ele é básico básico tem que cor? qual a substância que você então descobriu que eram básicas? a partir de que momento que você falou que era básica? por quê? tinha alguma substância que você usou que você tem essa noção? aí geralmente eles vão falar do vinagre.... porque ele sabe que o vinagre é ácido... "ah porque deu o contrário do vinagre (...) eu não dou nada para eles... apenas eu dou indicadores e falo que vão mudar de cor no ácido básico... e aí eles vão ter que me mostrar né? tabelas... o porquê que ele separou daquele jeito... aí tem as perguntas focadas naquilo né? por que você acha que que o sabão... se for básico justifique o porquê

Em suas considerações sobre a participação dos estudantes em atividades de modelagem envolvendo o estudo de ácido-base, Erduran (1999) aponta que a percepção da mudança de cor do papel tornassol em contato com determinadas substâncias pode servir de base para a descrição de um modelo de ácido e de base $^{13}$.

Desse modo, o trabalho desenvolvido pela docente P5 pode contribuir para que os estudantes elaborem e utilizem seus próprios modelos para explicar porque há mudança de cor do papel tornassol ou do papel de pH em meio ácido ou básico, bem como os motivos pelos quais substâncias ácidas ou básicas apresentam mudança de coloração na presença dos indicadores. Desse modo, embora P5 não tenha mencionado pormenores acerca de como desenvolveu a atividade descrita, envolver os estudantes na elaboração de uma escala qualitativa visual de $\mathrm{pH}$ pode aproximar os estudantes da prática química, bem como permite a discussão acerca de sua natureza específica.

Assim, de maneira geral, as falas dos sujeitos sugerem que, em certa medida, eles incluem em sua prática a abordagem de questões importantes associadas aos modelos científicos, tais como a natureza, os limites e a abrangência dos modelos atômicos, assim como a respeito do processo e da provisoriedade envolvida na construção desses modelos. Ademais, alguns docentes mencionaram atividades de

$13 \mathrm{Um}$ dos exemplos fornecidos pela pesquisadora a esse respeito é um modelo de ácido e base elaborado por um estudante, o qual relaciona os ácidos a "cores quentes" e as bases a "cores frias". Para isso, ele toma por base o conhecimento de que o papel tornassol azul fica vermelho em presença de uma solução ácida, enquanto o papel de tornassol vermelho fica azul em contato com uma solução básica. 
elaboração de modelos e explicações acerca dos fenômenos estudados, as quais permitem a consideração de características específicas da química.

Por outro lado, ainda se observa na abordagem dos professores um foco nos aspectos conceituais relacionados aos modelos em detrimento da discussão mais profunda acerca de como e porque eles são desenvolvidos na química. No que tange, por exemplo, à natureza dos modelos científicos, nenhum docente mencionou a preparação de atividades que permitam a discussão sobre o conceito científico de modelo e como este difere da concepção que os alunos já possuem sobre esse tema. Segundo Justi e Gilbert (2003), os estudantes não modificam suas visões sobre a natureza dos modelos como resultado da transmissão direta de definições formais ou mediante a análise de um modelo em particular. Desse modo, uma discussão mais abrangente sobre os modelos na ciência, suas funções e limites, permite que os docentes identifiquem os conhecimentos prévios dos estudantes sobre modelos e favorece a compreensão deles acerca do tema.

Com relação especificamente à química, nenhum docente citou discussões que abordassem a relevância dos modelos para a síntese das novas substâncias, atividade que distingue a química das outras ciências e evidencia seu caráter tecnocientífico.

Outra questão que não apareceu no discurso dos sujeitos ao relatarem suas práticas foi a preparação de atividades de modelagem nas quais os alunos pudessem testar e reelaborar seus modelos. De acordo com Mendonça (2011), tais atividades favorecem a aprendizagem acerca de como o conhecimento científico é elaborado e favorecem o desenvolvimento do pensamento científico dos estudantes.

O principal foco dos docentes ainda parece residir na explicação e na compreensão dos fenômenos, e não nos aspectos epistemológicos envolvidos. Nesse sentido, nenhum deles mencionou discussões explícitas acerca do processo de modelagem na ciência e na química. Além disso, ao considerarem uma atividade que propunha tal abordagem, alguns professores, conforme sugerem as falas abaixo, se limitaram a comentar sobre a importância de se realizar um "fechamento" dos assuntos trabalhados. Nenhum deles citou a consideração de aspectos envolvidos no processo de construção de modelos, tais como a criatividade dos cientistas e cooperação entre eles. 
é fundamental... né?

$----$

P4: com alguns... com a minoria... talvez possa possa conseguir... que nem eu falei... fazer uma atividade de fechamento né?

\subsubsection{Relevância}

A maioria dos docentes entrevistados considerou importante a abordagem dos modelos científicos no ensino de química. Apenas o sujeito P1 emitiu opiniões negativas acerca do tema, conforme evidenciam as falas a seguir.

Hirayama: você acha importante (...) os alunos saberem (...) essa questão ((dos modelos, de modo geral))?

P1: olha... atualmente? atualmente... não é tão interessante... não é

Hirayama: nem aqui ((na ETEC)) nem lá ((na escola estadual))?

$P 1:$ Ã̃O é... não quero dizer que.:.: você não fale... tá?

Segundo o professor, atualmente, a discussão em torno dos modelos científicos não é interessante nem importante para os estudantes. Apesar dessa consideração, P1, em outro momento da entrevista, apontou que o ensino de determinados conteúdos da disciplina de química, como polaridade e geometria molecular, depende da abordagem de aspectos conceituais associados aos modelos curriculares.

Hirayama: (...) você acha importante trabalhar essa questão (...)

P1: (...) como é que você vai falar da polaridade da água se você não falar o modelo angular que ela é... entendeu? então "porque que a água é... polar e não apolar? porque a água não é cento e oitenta graus... e ele tem cento e quatro graus... tá? porque que ela é assim?" até você chegar... no:..:s pares de elétrons disponíveis que fazem com que a água seja comparada a um tetraedro... que nem é do carbono (...)

Justi (2010), com base no trabalho de Hodson ${ }^{14}$ (1992), aponta a obtenção de conhecimentos declarativos e informações conceituais sobre modelos como um dos aspectos importantes da aprendizagem desse tema. Assim, a compreensão dos modelos curriculares que buscam explicar os fenômenos estudados tem um papel relevante na educação científica. Apesar disso, restringir o ensino de modelos apenas à transmissão dos conteúdos envolvidos não tem contribuído para que os

14 HODSON, D. In search of a meaningful relationship: an exploration of some issues relating to integration in science and science education. International Journal of Science Education, v. 14, n. 5, p. 541-562, 1992. 
estudantes estabeleçam relações entre os níveis macroscópico e submicroscópico, o que é fundamental para a aprendizagem da química (Johnstone, 1993; Justi, 2010). Ademais, tal abordagem restrita pode reforçar visões equivocadas sobre a realidade dos modelos e o desenvolvimento do conhecimento científico (Erduran, 2001). Por isso, é importante que, ao considerar tal questão, os professores também discutam acerca da "natureza, abrangência e limitações dos principais modelos científicos" (Justi, 2010, p.215).

Entretanto, P1, em sua fala, não fez nenhuma referência aos modelos como representações, mas os associou diretamente à realidade. Por exemplo, ao comentar acerca da importância de se "mostrar" aos estudantes a relação entre polaridade e solubilidade, o docente não fez menção à função explicativa dos modelos, ou seja, à elaboração de modelos para explicar fenômenos como a miscibilidade, solubilidade, etc. Também se referiu à geometria da molécula de água e a sua polaridade não como modelos desenvolvidos para compreender as propriedades desse material e sua interação com outras substâncias, mas sim como aspectos factuais de entidades reais.

Assim como P1, a docente P4 também enfatizou a aprendizagem dos conceitos relacionados aos modelos curriculares estudados.

Hirayama: (...) o que você cobra assim de modelo? o que é mais importante eles saberem? P4: modelo atômico ou modelo ?

Hirayama: modelos em geral... pode ser do modelo atômico...

P4: (...) mostrar que (...) a matéria tem natureza elétrica... tem questão disso... depois tem que por aquelas questões de pegadinha pra ver se eles entenderam a diferença do modelo de Thomson e do modelo de Dalton (...) pergunto se eles entenderam também aquele negócio do espaço vazio para eles entenderem aquela experiência ((de espalhamento de partículas alfa)) porquê que ela foi tão importante (...)

De acordo com a docente, o principal foco do ensino de modelos atômicos históricos é que os estudantes compreendam a diferença entre os modelos e alguns aspectos conceituais a eles relacionados. Como visto anteriormente, aprender acerca das diferenças entre os modelos pode contribuir para que os estudantes entendam os limites de cada um deles e os motivos pelos quais novos modelos são utilizados (Erduran, 2001). Contudo, conforme mostra o trecho a seguir, a preocupação precípua da professora se relaciona com a aprendizagem dos conteúdos dos modelos históricos. 
Hirayama: (...) o que seria mais importante para eles... para os alunos? (...)

P4: aqui... não fala... mas aí você fala lá para eles... raios de carga... carga elétrica né? que já sabia experimentalmente... aqui não fala de eletricidade estática que já era conhecido dos gregos antigos mas aí você fala para eles... não tem... fala que:: a palavra elétron vem lá do... da resina... resina... petrificada era elétron em grego... aí eu falo... então fazia... experiência por Tales de Mileto... que fez isso... experiência... de eletricidade estática...

----

P4: (...) entender que carga elétrica fazia parte de qualquer coisa... menor átomo que seja tem carga elétrica... então eles entenderem que é tudo equilíbrio de carga elétrica (...) tem forças fracas forças de interação fortes... forças nucleares fracas... eles tinham que ter uma noçãozinha disso aqui agora (...)

(...)

P4: mas eles precisavam entender que a eletricidade vem da matéria... é importante isso aqui... todo material tem uma... tem aquela experiência lá... de ver quem conduz quem não conduz corrente elétrica que com aparelhinho também e importante

P4 não mencionou a importância de se compreender a complexidade envolvida na elaboração das ideias científicas e nem mesmo acerca da natureza dos modelos. Ademais, tal qual o sujeito P1, ela se refere aos modelos atômicos como se fossem factuais e reais, o que pode impedir discussões importantes sobre a função dos modelos e suas limitações.

P2 e P5 também apontaram a importância do estudo dos modelos para a compreensão de determinados conteúdos da disciplina de química, no caso, da relação entre as interações moleculares e os estados físicos dos materiais.

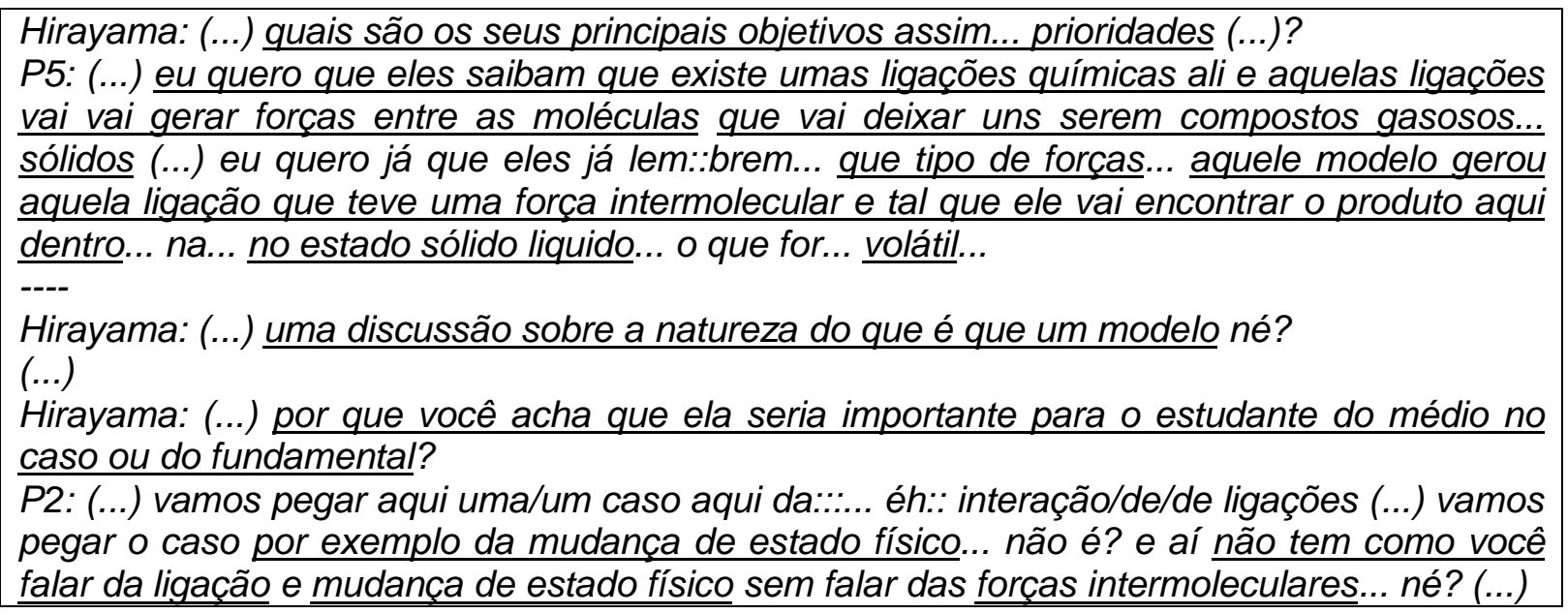

Assim como P1 e P4, a docente P5, ao mencionar quais são as suas prioridades na abordagem dos modelos, não fez referência aos conceitos de ligação, moléculas e forças de interação entre moléculas como modelos elaborados para explicar as propriedades dos materiais e os fenômenos estudados. 
A docente P2, por sua vez, embora tenha mencionado a aprendizagem de conceitos como um aspecto importante relacionado ao estudo dos modelos, também explicitou, diferente dos sujeitos $\mathrm{P} 1, \mathrm{P} 4$ e P5, que os estudantes devem relacionar os modelos apresentados ou construídos em sala de aula com o modelo original, aceito pela comunidade científica.

P2: (...) eu iria cobrar essa... essa relação do modelo original para um modelo talvez que ele porventura criou ou que eu de repente criei dessa duplinha ((se referiu ao modo gestual)) para poder explicar... isso eu ia querer que ele fizesse né? (...)

Assim, a docente parece se referir à importância de o aluno associar os modelos de ensino, elaborados com o objetivo de facilitar a compreensão de aspectos dos modelos curriculares, com os próprios modelos curriculares, os quais são simplificações dos modelos científicos "originais", criados para o âmbito escolar.

De acordo com Justi (2010), o uso de diversos tipos de modelos de ensino (concretos, desenhos, gráficos, etc.) pode favorecer a compreensão dos conteúdos científicos. Entretanto, para que tal objetivo seja alcançado, ela considera importante que os alunos percebam que "um modelo de ensino funciona como uma 'ponte' para o entendimento dos modelos curriculares" (p. 218). Logo, assim como mencionou $\mathrm{P} 2$, é importante, por exemplo, que os estudantes relacionem adequadamente $\mathrm{O}$ modelo de ensino gestual (utilizado pela docente para explicar as interações moleculares) com o modelo curricular (interações dipolo-dipolo, ligações de hidrogênio, etc.). Tal associação é facilitada quando os alunos compreendem as funções dos modelos e o processo pelo qual eles são elaborados na ciência.

Com respeito a essas questões, P2 também apontou a importância de se considerar alguns aspectos relacionados aos motivos pelos quais os modelos são elaborados.

P2: (...) eu acho que é interessante você trabalhar essa coisa dos modelos... né? que alguém se preocupa (...) em criar estratégias para passar um conhecimento de alguma coisa para alguém... isso eu acho interessante.

Segundo a professora, a preocupação dos cientistas em criar estratégicas para transmitir determinados conhecimentos é outra questão interessante a se abordar em relação aos modelos. Visto que, na química, um dos principais objetivos de se elaborar modelos é favorecer a comunicação de ideias, a abordagem desse 
aspecto contribui para que os estudantes se envolvam em discussões sobre o papel dos modelos no desenvolvimento da química (Justi, 2010).

Outro aspecto citado por P2, ao comentar sobre a importância de se trabalhar com modelos na disciplina de química, é a apresentação deles como construção histórica. Para ela, o ensino de modelos sob essa perspectiva contribui para humanizar e dar sentido à química.

Hirayama: (...) o que seria mais importante os alunos aprenderem assim dessa parte ((modelos históricos))? (...)

P2: eu acho assim ó... é uma construção humana... sabe? alguém pensou... parou... teve um momento para parar... um momento não... vários momentos - - que não é de uma hora pra outra... né? - - para criar alguma coisa... essa construção humana... isso eu acho mais fundamental... eu acho que isso inclusive humaniza também dá mais sentido à química

A importância da consideração dos diversos modelos atômicos elaborados no decorrer da história também foi mencionada pelo professor P1.

Hirayama: e o que você acha importante dessa parte ((dos modelos))? (...)

P1: a evolução... a evolução da matéria... mas contada de uma forma assim NÃO... tão... tão... ahn:: lenta::mente né? eu iria um pouquinho mais... é... rápido e deixaria com que cada um fizesse a sua evolução

(...)

Hirayama: (...) mas isso você acha que é interessante (...) no daqui ((na ETEC)) também?

P1: não:: aqui ((na ETEC)) não vai ser interessante

Hirayama: e aqueles que não vão ser químicos... por exemplo... que... seriam lá do Estado

P1: muito rápido

Hirayama: você acha que não...

P1: MUl::to rapidamente

Hirayama: nessa questão o que você acha importante o aluno saber?

P1: a experiência do Rutherford... eu acho

Hirayama: porque você acha que é que é...

P1: para mostrar a diferença do átomo... aonde tem os elétrons... o núcleo né?... aonde acontecem as coisas... pararia por aí... não entraria mais a fundo... em outros tipos de partícula... tá bom demais.... acabou (...)

A abordagem de modelos como elaboração humana, que visa objetivos específicos, favorece a superação de concepções ingênuas acerca da ciência e do seu desenvolvimento (Cachapuz et al, 2005). Na prática pedagógica, trabalhar sob essa perspectiva, segundo Porto (2010), envolve a consideração de assuntos, como a cooperação entre os cientistas, as hipóteses que orientaram as questões dos cientistas, os múltiplos fatores que influenciaram a aceitação ou abandono de 
determinadas ideias e outros que deem aos alunos a oportunidade de vislumbrarem a complexidade envolvida no empreendimento científico.

Entretanto, as falas de P1 acima reforçam a ideia de que, para ele, essa discussão não é tão relevante, e por isso deve ser feita rapidamente. Segundo o docente, os estudantes devem, posteriormente, se aprofundar em tais assuntos. Além disso, o docente enfatiza apenas os conteúdos associados ao modelo de Rutherford, porém não faz nenhuma referência acerca do processo de construção de tal modelo.

Para P2, por sua vez, conforme sugerem as falas abaixo, mostrar aos alunos que os modelos são construções humanas não envolve a consideração de características importantes inerentes ao processo de construção do conhecimento científico.

P2: (...) acho que tem que ser valorizado quem parou para pensar elaborar alguma coisa né? acho que tem que ser dado o.: seu devido valor o seu devido crédito (...)

----

Hirayama: por que... assim/você acha importante trabalhar essa questão?

(...)

Hirayama: dos modelos históricos?

P2: (...) eu acho importante porque você tem que valorizar o que cada um fez(...)

A professora aponta que evidenciar aos estudantes o esforço e o tempo empreendidos pelos cientistas na elaboração dos modelos pode fazê-los perceber a importância da perseverança, da dedicação e dos estudos para a consecução dos seus objetivos.

P2: (...) pensar num modelo explicativo para uma ideia... não é algo fácil... né? (...) acreditar naquele modelo e propor outro em cima (...) não é de uma hora para outra... né? hoje as coisas são muito assim... ((estalou os dedos))... a gente quer o retorno muito rápido também... né? infelizmente e os meninos mais ainda... né?

$---$

Hirayama: você acha importante? você faria essa discussão ((a respeito de discussões sobre a elaboração de modelos))?

P2: (...) isso eu acho que é fundamental... né? (...) para mostrar assim... que ninguém consegue desenvolver um modelo do nada... precisa de estudo... precisa de trabalho precisa de... de... perseverança sabe? persistir buscar e tal (...)

----

P2: (...) para você criar um modelinho desse... você abre mão de muito tempo da sua vida mesmo assim para... para fazer esse estudo e tal... isso não é valorizado... né? isso eu acho fundamental assim mostrar que é uma construção humana... e que ele como tal ele também pode mudar isso mas não é assim ((estalou os dedos)) de uma hora pra outra... isso requer tempo... requer trabalho... requer constância... perseguir objetivos (...) 
Com base nessa perspectiva, pode-se considerar alguns aspectos da construção dos modelos, como a motivação do cientista e o fato de que ele "não resolve de imediato os problemas que se lhe apresentam, mas em geral dedica muito estudo - mudando por vezes de opinião ao longo do processo" (Porto, 2010, p.176). Entretanto, a abordagem histórica dos modelos com o intuito precípuo de apontar os cientistas como exemplos a serem seguidos pelos alunos, principalmente por aqueles que pretendem seguir carreira na área, pode limitar a abordagem de outras questões relevantes do trabalho científico, tais como os diversos modelos científicos que coexistiam em determinado período, as divergências entre cientistas e a colaboração entre diferentes cientistas na elaboração dos modelos (Beltran et al., 2014).

Para P2, a compreensão da ciência como uma construção humana - o que, em sua visão, envolve principalmente dar o devido crédito aos cientistas e, com base nisso, apresentá-los como exemplos a serem seguidos - é fundamental para os estudantes que irão atuar na pesquisa científica.

P2: (...) se o menino achar que isso é o que ele vai fazer na vida... ele tem que entender que isso não é como um aplicativo de um celular de uma hora pra outra... precisa de dedicação... né? então é fundamental pra ele entender que é uma construção huMANA

Além da formação de cientistas, outra preocupação de P2, ao comentar os assuntos que considera relevantes no ensino de modelos, é com a cobrança de alguns dos conceitos estudados em exames vestibulares e no ENEM.

Hirayama: (...) qual/assim/quais as prioridades que você pensa em relação a isso ((abordagem de modelos))? (...)

P2: (...) é que isso de alguma maneira vai ser cobrado dele... ou no ENEM... éh... ou no vestibular e tal... mas em algum momento ele vai ser cobrado nem que seja só aquilo ali... só daquele ponto

Apesar de apontar a preparação para tais provas como uma de suas prioridades, a professora também considera que o entendimento sobre a provisoriedade dos modelos pode estimular a criticidade dos alunos.

Hirayama: (...) o que que você acha que é mais importante eles saberem? (...)
P2: porque não é uma verdade absoluta... não é uma verdade absoluta a gente tem que pôr
em dúvida... né? éh.: não é uma verdade absoluta ponto... né? e... eles estão ali... eles têm
que ter condicões para... para pôr em dúvida mesmo para questionar sim... como é que 
surge uma coisa nova? (...)

Para Kolstø (2008), mudar a noção de "fato científico", ou seja, de que a ciência lida com verdades absolutas, é importante para o debate democrático. Segundo ele, a compreensão de que os princípios científicos podem mudar em função, por exemplo, do surgimento de novas ideias, pode contribuir para que o cidadão se envolva e participe em questões sobre a ciência que afetam sua vida.

No que se refere à consideração dos modelos atômicos históricos, P5, assim como P2, também considera a importância de se valorizar o tempo dispendido pelos cientistas para a elaboração das ideias cientificas.

Hirayama: (...) a discussão desses modelos históricos (...) qual (...) é a sua opinião sobre essa discussão? qual a importância:: ou deles?

P5: para eles terem uma ideia de/do tempo primeiro o tempo que demora para você para um cien/tanto que um:: cientista demora para chegar numa resposta de uma pesquisa... para eles darem valor a isso... quando eles veem lá o tempo de Dalton para Thomson... eles até... "nossa professora vai tudo isso?" eu falo assim "é... então tudo caminha lentamente porque antes de se ter a teoria precisa de fazer várias comprovacões" (...)

P4 também mencionou a importância de mostrar aos estudantes que o conhecimento científico é resultado de um longo processo que envolve a contribuição de diversas pessoas.

Hirayama: (...) o que seria mais interessante os alunos aprenderem desse/dessa questão aqui ((modelos históricos))?

P4: (...) para eles é importante eles verem que... não é assim... peguei pronto aqui...vou lá que nem o sanduiche está pronto vou mastigar entendeu? veio um cara aqui e falou uma coisinha... vinte anos depois veio outro... às vezes estavam fazendo experiências semelhantes em países diferentes mas... não tinha comunicação de um país com o outro como tem hoje então um cara lá na França fazia uma experiência o outro na Inglaterra e o outro nos Estados Unidos e não tinha troca entre eles... e demorou quase cem anos para juntar tudo e fazer uma coisa tá? (...)

Embora as ideias apontadas pelas docentes possam promover a discussão sobre a ciência, as noções de que a demora na elaboração das teorias ocorre em função da necessidade de "comprovações" (apresentada por P5) e de que, anteriormente, a falta de comunicação impedia o acúmulo de ideias (mencionada por P4), dificultam a consideração dos múltiplos fatores que afetam o trabalho dos cientistas e o desenvolvimento da ciência. 
Além disso, o foco de P5 com respeito a essa abordagem é que os estudantes percebam como, atualmente, o desenvolvimento tecnológico se dá numa velocidade maior que antigamente.

Hirayama: para você o que é mais importante o aluno saber disso? qual é o seu objetivo?
quando você... trabalha essas questões... o que você... dá bastante ênfase? (...)
P5: como a tecnologia muda tudo... é isso que eu (...) deixo mais aSSIM em cima (...) em
cem anos o que acontece... tudo... e eu falei... eles ficam bem claros disso daí né? que a
tendência é... agora a ciência começar a... muitas coisas são bem mais rápidas hoje do que
eram antigamente (...)
(...)
P5: de trinta anos pra cá como que MUdou muita coisa
Hirayama: você acha que isso é importante para eles?
P5: ah é muito importante porque eles vão entrar no mercado de trabalho aí pelo menos
eles têm que saber escolher para o... o olhar para onde é que vai... ainda falo... a área de
$\underline{\text { informática tecnologia... pesquisa... isso é uma área muito boa... está sempre mudando... }} \underline{\text { equ }}$
$\underline{\text { aqui é um exemplo... né? }}$

Conforme sugerem as falas acima, o principal intuito da professora ao considerar tais questões é incentivar os estudantes a escolher alguma profissão na área da pesquisa e tecnologia.

O docente P3, assim como P2 e P4, também menciona a relevância de se abordar os modelos como construções históricas. Para ele, essa abordagem pode contribuir para que o estudante compreenda o funcionamento da ciência.

Hirayama: mas a importância? você atribui importância a essa discussão?

P3: a qualquer discussão que haja construção de conhecimentos eu acho... e de entendimento da construção... os modelos aceitos cientificamente depois... (...)

Hirayama: mas você acha que é importante por quê?

P3: de novo... construção de conhecimento... construção de conhecimento... de entender como esse conhecimento foi cons/por que está aí né? eu... eu acho superimportante...

Hirayama: (...) o que você acha importante os alunos saberem disso com essa questão de modelo (...)?

P3: abstração... abstração e entender conhecimento cientifico que é construído em cima de modelos que são ABANDONAdos na escolha de um melhor e que ele não é verdadeiro

P3, primeiro, apontou a importância da abstração no estudo dos modelos. Segundo Justi (2010), a elaboração e utilização de modelos na química ocorre em função das explicações químicas serem essencialmente abstratas. Assim, a compreensão dos conhecimentos químicos requer o estabelecimento de relações adequadas entre os níveis de representação macroscópico, submicroscópico e 
simbólico e, por isso, é fundamental que os estudantes desenvolvam a habilidade de abstração.

Outro aspecto, mais enfatizado por P3, foi a importância da compreensão sobre o processo de elaboração de modelos científicos. Embora, a princípio, o professor tenha apontado que os modelos são abandonados em prol de outros melhores, ele destacou a importância de se abordar a provisoriedade envolvida na construção da ciência.

Hirayama: (...) o que você acha importante eles entenderem de átomo... o que sobre átomo você acha importante entender sobre o que sobre equação química... quando você fala que "eles não entendem"

(...)

P3: só para repetição acho que não tem muita importância (...) o mais importante é entender que isso é filosófico e científico... isso pode tudo acabar né? (...)

Ademais, P3 fez referência ao fato de ainda, no ensino de química, utilizarmos modelos históricos, como o de Dalton, o qual não é aceito atualmente pela comunidade científica. A consideração desse ponto com os estudantes contribui para que eles compreendam que o mesmo fenômeno pode ser explicado por meio de modelos diferentes.

P3: (..) ajuda a pensar como pensou-se a ciência (...) é legal porque você acompanha a... as descobertas cientificas que vão mudando os modelos... isso é interessante para eles entenderem até como funciona a ciência (...) a ciência vai evoluindo a partir das descobertas do homem que força necessariamente... a organização de outros modelos explicar de outro jeito porque outra descoberta diz que aquele modelo... já não... já não responde a essa situação nova... mas também a ideia de coexistência porque a gente trabalha com modelo de Dalton né?(...)

P3 também apontou que a evolução da ciência ocorre em função de descobertas, realizadas pelos cientistas no decorrer da história, as quais forçam a organização de novos modelos. A abordagem dessa questão, sem a devida problematização acerca dos fatores externos (sociais, políticos e econômicos) que influenciam a aceitação e disseminação dos conhecimentos científicos, pode levar os estudantes a terem uma visão ingênua a respeito do trabalho científico, segundo a qual apenas questões científicas determinam a aceitação e disseminação de uma determinada ideia. 
Além de atribuir importância à compreensão do processo de elaboração dos modelos científicos, P3 também destacou o papel da escola na transmissão dos modelos aceitos atualmente.

P3: (...) a ciência é viva ela também muda (...) mas TEM uma orientação dentro desse país que onde quer que a sociedade viva... é tomado como $A$ verdade entre aspas e o que está estabelecido (...) qual é o papel da escola? se não é demonstrar essas teorias esses paDRÕES... mas não é a verdade (...) só que... dentro de uma sociedade dentro de um contexto você tem uma escolha de comportamento de ideia que é estabelecido (...) então por isso que eu acho que os modelos são extremamente importantes até para entender um pouco (...) e o papel da escola não é esse? apresentar os modelos (...)

As falas acima sugerem que, para P3, a aprendizagem dos conteúdos químicos, associados aos modelos, é tão importante quanto o entendimento da construção das ideias científicas. Ou seja, o docente aponta que o ensino dos conceitos científicos deve ser vinculado a abordagem dos meios e procedimentos pelos quais os conhecimentos foram obtidos ou transformados. Essa noção se coaduna com dois dos objetivos propostos por Justi (2010) para o ensino de modelos e modelagem em ciências, com base em Hodson (1992): aprender a natureza, limitações e abrangência dos modelos, assim como compreender e avaliar o papel dos modelos no desenvolvimento da ciência.

No decorrer da entrevista, P3 menciona os motivos pelos quais considera importante o entendimento de aspectos epistemológicos e conceituais relacionados aos modelos abordados. As falas a seguir sugerem que, para P3, uma das principais finalidades se abordar a ciência como construção é evidenciar aos estudantes as mudanças ocorridas na ciência em razão do surgimento de novas ideias. Segundo o professor, a compreensão desse ponto pode levar os estudantes a perceber a necessidade de transformarem algum aspecto de suas vidas em função da aquisição de novas informações.

Hirayama: (...) por que você acha que entender isso ((o funcionamento da ciência)) é importante... na sua visão?

P3: (...) eu acho que é importante porque... eles (...) poderiam entender que há uma. (...) evolução no pensamento e na construção do conhecimento... só isso e que não é à toa que não vem do nada não é alguém que... achou por bem fazer assim... é um acúmulo... tudo isso né? é um acúmulo de ideias... não é uma pessoa... são várias pessoas... vão aí chega uma hora que você preClsa mudar a perspectiva né? sobre aquele... sobre aquele ponto sobre aquele olhar... porque aquilo que você falava aquilo que você discursava já não:: abarca a realidade que você tem (...) acho importante para o ensino da ciência química ou da ciência em si... essa construção... dessa percepção que você tem que mudar... aí é 
importante até pro aprendizado... ó estou recebendo informações novas tenho que mudar... mudar a perspectiva (...)

Além disso, P3 aponta a importância de ensinar aos estudantes os conhecimentos científicos considerados valiosos pela sociedade. Para ele, embora seja fundamental o entendimento da influência da sociedade na elaboração dos modelos, não se pode tirar dos estudantes o direito de se apropriarem dos conteúdos escolares, os quais são cobrados na atual sociedade competitiva.

Hirayama (...) por que você acha importante entender a construção do conhecimento?

P3: para poder falar do mundo que você está né? isso se você tiver que repetir dentro da academia... (...) que ela acha que só a coisa que é certa é o que está lá dentro... agora... ele tem o diRElto de saber falar igual a academia (...) ah aí ele diz assim "ah porque a classe dominante tem nhe nhe" (...) aí você tira do aluno da escola pública o direito de saber como o dominante pensa como ele es/como ele lê o mundo como ele diz é o mundo (...)

P3: (...) isso aqui ((se referindo ao conhecimento científico)) é de homem branco europeu... nem discuto isso... é branco HOMEM gênero homem branco europeu... ponto... é o que está aí (...). não tem preto aqui... não tem oriental aqui (...) é homem acabou (...) mulher também não tem... acabou... sim... importante entender isso também... entender isso também... agora... porra ele está num mundo competitivo onde as coisas são teóricas... você é avaliado pelo que você sabe de repetir do homem branco europeu dentro da academia

Desse modo, os docentes P1, P4 e P5 apontaram a aprendizagem de conceitos como um dos aspectos centrais do ensino de modelos na disciplina de química. P2 e P3, por sua vez, além dessa questão, enfatizaram a relevância de se considerar com os estudantes os modelos como construções históricas, sujeitas a transformações. Entretanto, apenas P3 apontou a compreensão acerca da ciência como um dos principais objetivos de se abordar os modelos sob essa perspectiva.

Apesar de não terem mencionado, de modo espontâneo, a importância da participação dos estudantes em atividades de modelagem, quando questionados acerca de tal abordagem, a maioria dos sujeitos entrevistados apontaram algumas questões relevantes a respeito desse processo.

Novamente, conforme sugerem as falas abaixo, apenas o sujeito P1 não considerou a importância da participação dos estudantes em situações de aprendizagem nas quais sejam instados a elaborarem seus próprios modelos.

Hirayama: na verdade assim...é mais é::: da atividade deles fazerem um modelo...você acha importante ou não?

P1: não

Hirayama: não? 


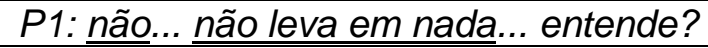

Já P3, novamente, assim como em relação a outras questões, mencionou apenas que é importante os estudantes elaborarem seus próprios modelos, pois assim estarão construindo conhecimentos.

Hirayama: você acha importante que eles façam?

P3: ah:.:. sem dúvida... construção né?.......)

P4, por sua vez, apontou a importância da modelagem na compreensão de conceitos da química.

Hirayama: por que você acha que é importante eles (los estudantes) tentarem fazer isso pelo menos ((elaborar modelos))?

P4: (...) muita gente sai daqui sem saber:: o que é íon... o que é que é molécula átomo e olha lá tá? (...) éh:: com muita dificuldade eles consequem entender que toda molécula tem duas partes uma positiva e negativa que ela pode ser iônica que ela pode ser molecular (...)

De acordo com Justi (2010), pesquisas em educação científica têm evidenciado que o ensino baseado em modelagem contribui para que os estudantes aprendam o conteúdo de modo significativo, ultrapassando a memorização de fatos e informações, assim como superem concepções equivocadas e dificuldades de aprendizagem em relação aos temas abordados.

Para P5, incentivar os estudantes a elaborarem seus próprios modelos é importante, pois pode fazer com que eles pensem mais e desenvolvam a capacidade de criar projetos.

Hirayama: (...) você acha que seria importante por que essa... permitir para os alunos pensassem isso ((elaborar modelos))?

P5: porque eles poderiam fazer uma construção de algo... por exemplo... éh:: um projeto... eu veria como projeto... você manda o aluno fazer qualquer projeto ele não sabe nem por onde começar a pensar

Hirayama: isso... então isso você acha interessante?

P5: é lógico que ele é interessante porque faz com que ele comece a pensar mais.

Assim como P5 mencionou, a participação do estudante em processos nos quais possam criar, expressar, testar e revisar seus modelos, promove, dentre outras capacidades, o desenvolvimento do pensamento científico.

Para P2, a relevância de tais atividades reside no fato de que para realizá-las, os estudantes precisariam estudar os conceitos relacionados aos modelos. 
P2: se eu conseguisse sim... eu acho que seria importante sim... ((realizar atividades nas quais os estudantes abordassem seus próprios modelos))

Hirayama: principalmente por que? você acha assim...

P2: porque acho que daria mais vida faria mais sentido para ele né? assim... ele estaria... primeiro ele teria que éh... justificar aquele modelo que ele criou né? para ele justificar ele teria que ter argumento argumento sem conhecimento fica... um achismo total né? então ele ia ter que estudar mesmo né (...)

Apesar disso, ao apontar a importância de os alunos justificarem os seus modelos, P2 aludiu a um aspecto fundamental envolvido na prática científica: a argumentação. A construção do conhecimento científico envolve a justificação de enunciados, conclusões, hipóteses ou teorias por meio de dados empíricos ou teorias. Desse modo, Jiménez-Aleixandre et al. (2000) defendem um ensino de ciências que, além da compreensão conceitual, envolva também a aprendizagem de certos aspectos da ciência e ofereça aos estudantes oportunidades para resolverem problemas, discutirem sobre ciência e utilizarem operações argumentativas e epistemológicas que fazem parte da cultura científica. Nascimento e Vieira (2008) apontam ainda que o desenvolvimento da argumentação em sala de aula permite que os estudantes possam vivenciar as práticas e discursos científicos; torna visível o pensamento dos alunos; os ajuda a produzir conhecimento; e promove uma participação mais ativa nas atividades propostas. Para Mendonça (2011), estratégias de ensino fundamentadas em modelagem favorecem 0 desenvolvimento do raciocínio argumentativo. Desse modo, a participação dos estudantes em atividades de produção de modelos análogas, em certa medida, ao que acontece na ciência, pode contribuir para que eles também desenvolvam a habilidade de argumentação, inerente ao desenvolvimento científico e importante na formação cidadã (Vieira e Nascimento, 2009).

Embora tenha, de certo modo, se referido à importância de um aspecto que faz parte do processo de modelagem, P2 não se referiu de maneira direta à elaboração de modelos por parte dos estudantes como uma atividade importante para que eles compreendam o processo científico de geração e avaliação dos modelos.

Com relação ao processo de modelagem, outro aspecto relevante que não foi citado pelos docentes é a discussão explícita sobre a modelagem. Segundo De Jong et al. (2005), embora esse processo tenha um papel central na química, os 
químicos, muitas vezes, usam os modelos sem terem consciência disso. Para De Jong et al. (2005), embora isso não prejudique a comunicação entre os químicos, na educação pode levar a problemas de aprendizagem. Desse modo, é fundamental que os estudantes não apenas participem dos processos de modelagem, mas também reflitam sobre eles.

O Quadro 04, a seguir, apresenta uma síntese das concepções e práticas dos sujeitos entrevistados no que se refere a abordagem do tema modelos $e$ modelagem. 


\begin{tabular}{|c|c|c|}
\hline Sujeitos & Prática docente & Relevância \\
\hline P1 & $\begin{array}{l}\text { Aborda, predominantemente, conceitos científicos, tais como conceitos } \\
\text { associados aos modelos atômicos históricos. }\end{array}$ & $\begin{array}{l}\text { - Compreender conceitos, tais como polaridade e geometria } \\
\text { molecular, bem como os aspectos conceituais } \\
\text { relacionados aos modelos atômicos históricos. } \\
\text { No entanto, de modo geral, considera desinteressante e } \\
\text { irrelevante a abordagem dos modelos e as atividades de } \\
\text { modelagem. }\end{array}$ \\
\hline P2 & $\begin{array}{l}\text { - Aborda o caráter coletivo envolvido na elaboração de modelos; o papel } \\
\text { explicativo dos modelos; a provisoriedade dos modelos; e os modelos como } \\
\text { representações. } \\
\text { Trabalha com atividades de criação e utilização de modelos no ensino } \\
\text { fundamental, porém, no ensino médio, tem como foco o ensino de aspectos } \\
\text { conceituais. }\end{array}$ & $\begin{array}{l}\text { - } \text { Compreender aspectos conceituais. } \\
\text { - } \text { Compreanar modelos de ensino com os curriculares. } \\
\text { elaborados. } \\
\text { Valorizar os cientistas, que servirão de exemplos aos } \\
\text { estudantes. } \\
\text { - Estimular os estudantes a estudar. } \\
\text { - Freparar para o ENEM e exames vestibulares. } \\
\text { - Estimular criticidade. }\end{array}$ \\
\hline P3 & $\begin{array}{l}\text { - Aborda as limitações e abrangências dos modelos atômicos históricos; o } \\
\text { papel explicativo dos modelos; a provisoriedade dos modelos; e os modelos } \\
\text { como representações. }\end{array}$ & $\begin{array}{l}\text { - } \quad \text { Compreender conceitos e modelos curriculares e } 0 \\
\text { funcionamento da ciência. } \\
\text { - Desenvolver capacidade de abstração. } \\
\text { - Vislumbrar possibilidades de transformações. }\end{array}$ \\
\hline $\mathrm{P} 4$ & $\begin{array}{l}\text { - Aborda detalhes dos experimentos envolvidos na proposição de modelos } \\
\text { históricos; a provisoriedade dos modelos; e de que modo os modelos } \\
\text { contribuem para o desenvolvimento científico e tecnológico. }\end{array}$ & $\begin{array}{l}\text { - Compreender conceitos (natureza elétrica da matéria, } \\
\text { íns, átomos, moléculas). } \\
\text { Desenvolver a consciência acerca do tempo necessário } \\
\text { para a elaboração dos conhecimentos científicos. }\end{array}$ \\
\hline P5 & $\begin{array}{l}\text { - Aborda conceitos científicos relacionados aos modelos atômicos históricos; } \\
\text { as diferenças entre os modelos; e as motivações e objetivos dos cientistas } \\
\text { no desenvolvimento dos modelos atômicos históricos. } \\
\text { Trabalha com atividades práticas que podem favorecer a elaboração e a } \\
\text { utilização de modelos por parte dos estudantes. }\end{array}$ & $\begin{array}{l}\text { - Compreender conceitos (com foco nas interações } \\
\text { moleculares). } \\
\text { - Perceber a atual rapidez do desenvolvimento tecnológico } \\
\text { para contribuir para a escolha profissional. } \\
\text { - Estimular o pensamento. } \\
\text { - Desenvolver a capacidade de elaborar projetos. }\end{array}$ \\
\hline
\end{tabular}

Quadro 04: Quadro-resumo das concepções e práticas dos sujeitos entrevistados acerca do tema Modelos e modelagem. 


\subsubsection{Experimentação}

\subsubsection{Prática docente}

Devido à relevância da experimentação no desenvolvimento da ciência química, a sua inclusão no ensino dessa disciplina, em todos os níveis de escolaridade, tem sido considerada óbvia e natural por muitos professores e pesquisadores (Hofstein et al., 2013). Ainda assim, como evidencia Gonçalves (2005), a utilização de atividades experimentais na educação básica, principalmente nas instituições públicas, é pouco frequente.

$\mathrm{Na}$ presente pesquisa, tais fatos também foram constatados. Nos primeiros encontros, a experimentação foi o único aspecto mencionado, de modo espontâneo, por todos os docentes, ao apontarem os conteúdos e as estratégias que habitualmente utilizam no ensino de química. Apesar disso, ao serem questionados diretamente sobre o trabalho pedagógico com a experimentação, alguns sujeitos entrevistados (P1 e P3) revelaram que pouco realizam atividades experimentais nas instituições nas quais atuam.

Embora não tenha, nos últimos anos, desenvolvido nenhuma atividade experimental, P3 apontou que busca incentivar os estudantes a realizarem algumas práticas simples em suas casas.

P3: (...) nos últimos anos não fiz nenhuma atividade experimental... eu peço para eles fazerem... as coisas mais simples que estão nos livros...

(...)

P3: (...) não fiz só mando... mando fazer... mando do repolho roxo... peço dou descrevo... quando eu entro em ácido e base nos segundos anos... mas... eu não faço na sala... não faço não faço... na escola

P3: (...) pedi que eles jogassem um suco... em pó sólido em áqua e deixasse... e hoje eu recebi o trabalho (...) e perguntei "e aí? éh:: o que vocês observaram?" nossa... um negócio... cada um observou de um jeito... aí uma disse "não porque com tang dá errado"... aí outra disse (...) "não errado não... é o o tang... é outra coisa" (...)

P1 também mencionou o uso dessa estratégia, em função de obstáculos com os quais tem se deparado em sua prática pedagógica. O principal deles é a falta de laboratório na escola estadual em que trabalha. 
experimentos?

P1: quando eu mando... eles fazerem em casa e os que fazem dá para...dá para trabalhar bem... caso contrário não... agora me fala em porcentagem... de cem por cento... dois por cento fazem

Hirayama: mas geralmente:: é:: antes você dá alguma coisa?

P1: sim... eu comento sobre a expe/a parte experimental

Hirayama: e durante o que que é mais importante ali é::

P1: não... durante eu não eu não acompanho eu não acompanho eu não tenho condições de fazer a parte experimental... no Estado (...) e também não quero... também não quero (...) Hirayama: (...) depois dos experimentos o que que os estudantes comumente fazem?

P1: aí... normalmente eles entendem o fechamento... a teoria com o experimental (...)

Nos trechos acima, P3 afirmou que fornece aos estudantes a descrição das etapas necessárias à realização das atividades, assim como elabora questões para incentivá-los a descrever os fenômenos que observaram em suas casas. P1, por sua vez, apesar de não ter detalhado de que maneira articula a prática realizada pelos alunos em suas residências com os conhecimentos trabalhados em sala de aula, disse que, após a experimentação, os estudantes conseguem associar a teoria com a parte experimental. Sua fala sugere, porém, que o experimento tem a função de comprovar o que foi visto na aula teórica.

A utilização de "experimentos" em casa como subterfúgio - embora possa estar relacionada com as dificuldades encontradas na escola para a realização de atividades práticas e permita, até certo ponto, a discussão sobre os fenômenos estudados - restringe o potencial pedagógico da experimentação no ensino de química.

De acordo com Hofstein e colaboradores (2013), atualmente, dentre as principais capacidades a serem fomentadas por meio das atividades experimentais estão as habilidades metacognitivas, as quais estão relacionadas com a aquisição de conhecimentos acerca de como e quando utilizar estratégias adequadas para aprender ou resolver problemas. Hofstein e colaboradores (2013) enfatizam que o desenvolvimento da metacognição é favorecido pelo apoio e suporte docente durante a realização de atividades investigativas, nas quais os estudantes tenham a oportunidade de participar de discussões com os seus colegas e comunicar suas ideias; e nas quais o professor possa explorar os questionamentos realizados por eles, bem como contribuir para que tomem consciência acerca de suas ações físicas e cognitivas.

Assim como P1, P4 também mencionou obstáculos para inserir atividades experimentais na escola em que trabalha. Segundo ela, o uso da experimentação 
em sua prática pedagógica somente é possível com o auxílio de um ajudante ou por meio de atividades demonstrativas. Ainda assim, como exemplos de boas práticas experimentais, a docente apontou apenas demonstrações que foram desenvolvidas em conjunto com o então estagiário da escola.

Hirayama: você lembra uma aula (...) de experimentação (...) que você acha que foi boa?

P4: (...) um menino ((estagiário)) fez a experiência de fazer aquela geleca lá fazer um polímero... né? colorido aí ele trouxe botou... um corante ficou bonito o colorido (...)

P4: (...) ((o estagiário)) fez experimentação com um liberação de gases coisas simples bicarbonato com vinagre (...)

----

P4: (...) já fez aquela experiência de condutividade eles gostam de fazer aquela de acender (...)

Além de P4, a docente P2, ao ser solicitada a descrever uma experimentação bem-sucedida que realizou no ensino médio e como costuma incluir esse aspecto em sua prática, também mencionou 0 uso de atividades experimentais demonstrativas.

Hirayama: (...) lembra de alguma experimentação que você fez e (...) considera foi boa (...)? (...)

P2: (...) eu peguei e testei o ponto de... de ebulição da água... né? (...) então eu não tinha o bico de Bunsen... eu tinha lamparina só.

P2: (...) então a gente foi lá (...) na cozinha... que tem o fogão e tudo o mais (...) então conversei com os meninos que nós íamos fazer o experimento LÁ... eles iam SIMplesmente observar

P2: (...) mostrar... éh:: as evidências de que ocorreram uma atividade... aliás... uma... uma reação química (...)

Hofstein e colaboradores (2013) apontam que as demonstrações podem ser valiosas nos casos em que os materiais e reagentes a serem utilizados são caros e escassos, a prática envolve o uso de substâncias tóxicas, o tempo para se desenvolver a atividade é escasso, ou o principal intuito do professor é apresentar uma técnica ou um determinado aparato. Segundo os pesquisadores, atividades demonstrativas planejadas de modo adequado podem contribuir para o desenvolvimento de habilidades como observação, coleta de dados e elaboração de questões relevantes cientificamente.

Em consonância com tais ideias, as falas a seguir sugerem que, no decorrer de algumas atividades citadas pelas docentes entrevistadas, os estudantes foram 
informados dos procedimentos a serem realizados e instados a observar os fenômenos e registrar os dados.

P4: (...) você dá uma explicacão fala um roteiro básico aí no dia você tem que vir com meia folha uma folha assim impressa aí eles tão lá o resumo né? o procedimento e o... o que eles registrar (...) se deixar por conta deles vira uma bagunça

---

P4: (...) a gente passa na lousa uma tabela um aluno vai ajudando a marcar lá "acendeu" "não acendeu" "positivo" as lâmpadas

---

P2: (...) eles iam anotar o/olos dados (...) botei a água lá no fogo... para esquentar com termômetro... né? com béquer e tal (...) o que eles tinham que fazer? eles tinham que anotar os dados (...) comecei a esquentar a água... né? a cada tantos minutos eles anotavam a temperatura (...) e aí eles foram anotando (...) e depois com esses dados (...) que todos eles anotaram e fizeram construíram uma tabela (...) saímos lá da cozinha voltamos para sala "agora nós vamos colocar isso num gráfico"... e ai a gente foi construir o gráfico...

Além disso, no caso da demonstração mencionada por P2, os alunos tiveram a oportunidade de utilizar as informações obtidas para elaborar um gráfico e uma tabela, habilidades básicas recomendadas pelos Parâmetros Curriculares Nacionais para o Ensino Médio (Brasil, 1999) e outras diretrizes relacionadas.

Outro aspecto positivo das atividades demonstrativas, segundo Silva e colaboradores (2010), é que elas podem ser desenvolvidas de modo a minimizar a desarticulação entre teoria e prática, muito observada nos experimentos que têm como foco "comprovar na prática" o que foi considerado teoricamente. Para isso, os pesquisadores indicam a relevância de se identificar as concepções prévias dos estudantes acerca dos fenômenos estudados, elaborar questões que promovam discussões entre eles e permitir a formulação e o teste de hipóteses. Hofstein e colaboradores (2013) apontam que elaborar questões, durante a demonstração, sem fornecer prontamente as respostas, tem o potencial de aumentar a motivação e o interesse dos estudantes pelo estudo da química.

No que tange a essas questões, as falas de P2 e P4 a seguir indicam que, até certo ponto, elas procuram promover a discussão em sala de aula a respeito das observações realizadas e dos conceitos envolvidos, o que pode estimular o estabelecimento de relações apropriadas entre os modelos explicativos e os fenômenos observados.

P4: (...) eles ficam querendo entender porque que o álcool não acende a luz (...)

P4: (...) a discussão fica na próxima aula (...) 
P4: (...) aí eles "ferveu" "ferveu como?" aí a gente não... "ferveu como? você não está vendo que não aqueceu?"... eles logo falam "ah ferveu" porque viram as bolhinhas" aí eu mando eles segurarem... "aqueceu?" "não" "como é que chama isso?" (...)

----

P2: (...) e aí gente foi explicar o que que foi... eles foram primeiro deduzir o que era aqueles noventa e oito ponto alguma coisa? primeiro por que não era cem? já que o ponto de ebulição da água é cem... por que aqui em São Paulo não dava cem? né? (...) por que formava aquele patamar no gráfico e tudo o mais (...)

P2: (...) o resultado foi muito bom (...) teve discussão porquê que o ponteiro lá do termômetro... por que o mercúrio não subia mais (...)

Dentre as atividades que citou, P4 destacou o teste de condutividade elétrica de diferentes soluções.

P4: (...) porque aí eles ficam entendendo (...) que a matéria tem natureza elétrica é uma coisa abstrata para eles quando eles veem que acende não acende acende mais forte acende mais fraco eles entendem que o que que é a matéria e o material que eles usaram... P4: essa é uma aula prática legal de se fazer... eles entendem melhor a matéria tem natureza elétrica quem conduz corrente elétrica são os materiais

Segundo ela, a importância dessa demonstração reside no fato de que, ao observar os resultados experimentais, os estudantes passariam a entender a natureza elétrica da matéria, algo que para eles é muito abstrato.

Apesar de a experimentação ser um dos elementos mais importantes na promoção da aprendizagem em química, a simples visualização dos fenômenos não facilita instantaneamente a compreensão dos conceitos científicos. Silva e colaboradores (2010) explicam que modelos e teorias não são o mundo concreto que se mostra ao ser humano, mas sim elaborações dos cientistas que promovem um afastamento da realidade imediata. Por isso, a atividade científica de experimentação não concretiza a teoria, já que esta é realizada com base em conceitos prévios. Para Gonçalves (2005), a ideia de que é possível, por meio da mera observação, entender um construto teórico se relaciona à visão empirista da ciência, segundo a qual a interpretação segura de um fenômeno pode ser realizada apenas pela sua observação. O pesquisador aponta que a condução de atividades experimentais para mostrar uma teoria pode favorecer o desenvolvimento de ideias equivocadas acerca da atividade científica, como a de que as teorias e modelos científicos são conhecimentos verdadeiros "extraídos" diretamente da Natureza.

P2 mencionou que, de acordo com a série e os conteúdos trabalhados, utiliza atividades experimentais ao final de um determinado assunto. 
P2: (...) às vezes eu uso a experimentação NO final... depois que eu expliquei vamos pegar o caso do... do... do ferro... do prego... que você joga lá...

(...)

P2: na água e tudo o mais e tal... que vai mudando de cor coloca no sulfato de cobre e tal... né? (...) então a eVIdência da... da cor também (...) dá pra você perceber ali belezinha... essa daí na mesma turma eu usei no final...

Hirayama: entendi...

P2: então depois que eu trabalhei ó... liberação de gases... formação de precipitado... mudança de cor (...) aí a gente vai para o laboratório... aí NO laboratório é que eles foram vendo... in loco.

As falas acima indicam que, ao realizar tais atividades, a docente tem como intuito principal apenas ilustrar conceitos abordados nas aulas teóricas e não a aprendizagem acerca dos fenômenos estudados por meio do estabelecimento de associações adequadas entre teoria e prática.

Para Silva e colaboradores (2010), ter como foco na experimentação apenas os aspectos macroscópicos, desconsiderando-se os aspectos microscópicos relacionados, limita a aprendizagem dos estudantes acerca dos conceitos e da prática científica, promovendo uma visão dicotômica entre teoria e prática. Mais especificamente em relação à química, Lemes (2013) enfatiza que os fenômenos observáveis, tais como as evidências de reações (produção de gás, calor, mudança de cor, etc.) não possuem relação intuitiva com o comportamento submicroscópico dos materiais envolvidos. Desse modo, Lemes (2013) aponta o papel da experimentação na química em explicitar as relações entre as evidências experimentais, os conceitos e os modelos químicos. Desse modo, o uso adequado de atividades demonstrativas pode favorecer a aprendizagem de conceitos químicos e o desenvolvimento de capacidades importantes para a formação integral dos estudantes. Entretanto, em geral, assim como foi sugerido em relação aos docentes entrevistados, tais atividades não têm sido utilizadas para propor desafios cognitivos: ao contrário, têm mantido os estudantes em uma posição passiva, como meros espectadores de fenômenos e receptores de informações conceituais (Hofstein et al., 2013).

Além de demonstrações, alguns sujeitos entrevistados mencionaram a utilização de atividades nas quais os próprios estudantes, em grupo, realizaram as práticas propostas. No entanto, o uso regular desse tipo de experimentação foi citado apenas por P5. 
que foi bem-sucedida (...)?

P5: foi uma reação de decomposição da água oxigenada usando ( ) o iodeto de ... o iodeto como catalisador (...) os próprios alunos que fizeram

P5: (...) é sempre em grupos... são os próprios alunos que vão realizar né?

Os trabalhos práticos realizados com a participação efetiva e direta dos estudantes são recomendados pelas pesquisas em educação, pois, se planejados de modo eficiente, podem favorecer, além da compreensão dos problemas elaborados pelo docente, o desenvolvimento de capacidades tais como: manusear materiais, trabalhar cooperativamente, investigar, formular perguntas cientificamente relevantes, planejar novos experimentos e argumentar (Hofstein et al., 2013). Para isso, é importante que os docentes preparem ambientes de aprendizagem que se aproximem da prática química e permitam a articulação entre teoria e prática (Schumacher \& Reiners, 2013; Erduran, 2007).

Um dos principais papéis da experimentação na disciplina de química é facilitar o estabelecimento de relações entre o domínio das ideias (teorias) e o domínio dos observáveis (fenômenos) (Hofstein et al., 2013; Silva et al., 2010). Segundo Hofstein e colaboradores (2013), para que tal vínculo ocorra, é fundamental introduzir aos estudantes alguns conceitos de modo que eles consigam explicar os fenômenos observados. Para eles, ainda que

estas relações sejam desenvolvidas em aulas posteriores, o fato de as ideias não estarem disponíveis para os alunos usarem na aula, as quais lhes permitam dar sentido à atividade (perceber sua finalidade) ou as observações feitas (para interpretá-las à luz do quadro teórico de ideias e modelos), pode inibir a eficácia do trabalho prático como um evento de aprendizagem nas aulas de química (p. 166).

Como indica o trecho a seguir, antes das atividades práticas, P5 apontou que costuma abordar alguns aspectos teóricos, assim como preparar e entregar aos estudantes uma série de perguntas com o objetivo de direcionar a atenção deles aos fenômenos a serem estudados.

P5: (...) geralmente eu passo primeiro a... a teoria... mas eu não explico nada do que vai acontecer eu apenas falo o que é um catalisador mostro... onde ele... algumas coisas que eles alteram e uma delas seria a velocidade (...)

P5: sempre assim... eu primeiro dou a introdução começo a matéria normal (...) ----

P5: (...) eles recebem:: um procedimento normal eu ponho na lousa e explico antes e eles 
vão fazendo durante uma aula (...)

P5: eles já recebem já o procedimento e um mon/várias perguntas... que é exatamente para que todos do grupo prestem atenção no que está acontecendo para não passar (...) eu faço pergunta por exemplo "está saindo gás? por que? qual você acha que é?"

Ademais, mencionou que os incentiva a fornecerem explicações para as observações realizadas. Tal ação é importante, pois pode favorecer a discussão e interação entre os alunos, bem como o estabelecimento de relações entre o fazer e o pensar.

P5: é nas minhas aulas sempre eles discutem alguma coisa ( ) eu faço perguntas "por que que é isso?" eles sempre têm a discussão (...)

P5: (...) são oito grupos que fazem ao mesmo tempo... um vai dar uma coisa outro vai dar outra um vai ter uma ideia vai ter outra... e aí vem sempre a discussão... entendeu?... até densidade por exemplo... eu dei para o aluno calcular a densidade do álcool e para um deu dez e para o outro deu zero oito então... qual é o problema? então vamos descobrir por que um deu um valor e porquê o outro deu outro... o que vocês acham? (...)

Apesar disso, P5 não fez nenhuma referência ao envolvimento dos estudantes em tarefas por meio das quais pudessem formular e testar hipóteses experimentais, bem como discutir suas concepções com os colegas. Assim, o foco da docente, ao introduzir os conceitos científicos antes das práticas de laboratório, não parece ser engajar os estudantes em atividades que se aproximem da prática científica.

O trecho a seguir sugere que, ao introduzir conceitos e promover discussões, P5 tem como intuito principal fazer com que os estudantes respondam corretamente atividades, exercícios e perguntas abordadas anteriormente em sala de aula.

\footnotetext{
P5: (...) eu peço para que eles coloquem den::tro... o bicar/pesam bicarbonato põe dentro do saquinho põe ácido clorídrico fe:.:.cha pesa tudo primeiro... sem... sem nada aí eles marcam a massa... aí eles mistu::ram fecham pesa de novo a massa é parecida a::bre pesa de novo aí diminuiu... mas quando eles vão fazer isso daí eles já sabem o motivo...

Hirayama: entendi...

P5: porque ele aprendeu antes...

Hirayama: entendi...

P5: entendeu? aí eles conseguem responder melhor aí eu falo assim "qual foi a massa então no sistema fechado?" então quer dizer eu... toco no nome de Lavoisier falo o que é o sistema fechado... o sistema aberto... né? que sempre a massa do início é a mesma do final (...)

P5: (...) nesse caso ((catalisador)) eu pedi exercícios... eram exercícios de fatores do livro e eles... era... como lição de casa... então eles fizeram os exercícios aí eles vieram nós
} 
corrigimos e depois que veio o experimento

$--\cdot$

P5: e depois vem a discussão aí vem a... como já tinha sido feito o exercício aí a discussão voltou com o gráfico - - que ela apagou ali né? - - ((apontou para a lousa do laboratório)) que aí nós fizemos o gráfico mostrando com catalisador e sem catalisador o que aconteceria com a curva... então unir foi unido com a matéria... foi só isso...

P5: aí vem aí então eles conseguem unir... aí nem precisa que eu fale... "professora aquele exercício lá... sabe?" o próprio aluno puxa... o assunto... aí e falei "está vendo? então vamos colocar de novo a reação na lousa para gente ver o que era daquele exercício"... aí eu dou o gráfico aí eles conseguem

Nesse sentido, a utilização da experimentação teria a função principal de promover o desenvolvimento de habilidades de manipulação e, por meio da observação, promover a compreensão sobre um fenômeno. As falas a seguir mostram que, assim como P4, a docente relaciona o "ver" com o "entender". Dessa forma, ela apresenta uma concepção empirista que desconsidera o papel da abstração e da criatividade na ciência.

\begin{tabular}{l} 
Hirayama: nessa atividade que você fez (...) o que era mais importante ali? (...) \\
P5: (...) eu queria que ele soubesse qual era a função de um catalisador... só foi para isso \\
Hirayama: entendi... a utilização da experimentação foi nesse sentido? \\
P5: sim foi nesse sentido... foi para eles verem como acelera né? usando o catalisador \\
P5: (...) eu disse que colocava catalisador e eles ainda não entendiam que ia liberar muito \\
gás então ia fazer muita espuma \\
\hline P5: (...) é muito difícil você explicar catalisador só falando... então eu pedi que eles \\
pegassem água oxigena:.:da para eles verem ahn: que realmente sai gás oxigênio aí nós \\
fizemos a reação química e quando eles colocaram o iodeto e aí foi RÁpido... e aí eles \\
\hline gostaram muito de ter visto aquilo e eu acho que entendeu muito bem o que é que era um \\
catalisador \\
---- \\
P5: (...) tem uma questão no livro sobre a água oxigenada dentro dessa matéria de cinética \\
então eles fizeram o exercício eles responderam eles acertaram o exercício mas eles... aí eu \\
olhei falei assim "poxa o que está aqui no exercício pode virar prática para eles verem que \\
aquilo que ele respondeu... tem... tem efeito né?" (...) aí eu escolhi catalisador porque eu \\
nunca tinha trabalhado e era uma questão do livro... eles resolveram tudo antes... \\
resolveram responderam e... só depois do experimento que aí aquela aquele determinado \\
exercício virou... foi outra... ele começa a ver de outro... de outra forma...
\end{tabular}

Por exemplo, a apreensão do conceito de catalisador não ocorre ao se observar a decomposição da água oxigenada acontecendo mais rapidamente em função da adição de um material. Para isso, seria necessária a compreensão de conceitos científicos como reação química, fatores que favorecem sua ocorrência e afetam sua rapidez, equação química, energia de ativação, etc. 
P1 também mencionou que envolve a participação dos estudantes na manipulação de materiais e reagentes. Embora tenha apontado que comumente pede aos estudantes que realizem algumas atividades práticas em suas casas, o docente indicou, reiteradamente, uma aula na qual os estudantes produziram sabonete líquido como uma boa prática pedagógica envolvendo a experimentação. A descrição fornecida por ele sugere que, nesse trabalho, o papel dos estudantes se resumiu a misturar os reagentes de modo a obter o produto esperado.

\footnotetext{
Hirayama: você/você já chegou a dar uma BOA aula experimental lá no Estado (...)

P1: é eu consegui essa que nós preparamos sabonete líquido (...)

----

P1: (...) eu falei "vamos fazer um detergente aí um... sabonete líquido... vocês querem fazer? (...) eu falo onde vocês tem que comprar ( ) tudo lá... compra lá" (...) "que essência você vai querer? ah... eu quero erva-doce... eu quero isso..." corante aqui... saiu cada um levou dois litros e meio pra casa... gastaram um pouquinho... por que que saiu lá?... entende? falei "ó dou uma receita para vocês como fazer material pra comprar"(...)

----

P1: (...) eles tinham a receita... e eu fui explicando o que eles tinham que fazer...eles trouxeram tudo de casa... bal:::de... ( ) como se fosse - - não um laboratório - - mas sim um processo uma "fabriquetinha" uma fábrica... eles produziram:.: (...)

(...)

P1: (...) aí o que eles falaram "professor até hoje minha mãe usa o.: sabonete líquido que eu preparei..." então eles saindo com aquele produto... enche... o ego deles so.:.be... "porra fiz na esco::/a... aprendi"
}

Segundo Erduran (2007), um ensino de química que ultrapasse a mera transmissão de fatos a serem memorizados envolve a participação dos estudantes em atividades que se aproximem da prática química autêntica e, assim, permitam a eles vislumbrarem o funcionamento dessa ciência e o trabalho dos químicos. Com relação a esse aspecto, Schummer (2004), tomando por base o exame de 300 artigos de pesquisa, aponta que o principal objetivo dos experimentos na ciência química é a síntese e análise de substâncias. Assim, a atividade proposta por P1 poderia, em certa medida, aproximar os estudantes da prática, comum na química, de sintetizar materiais e ser utilizada para promover discussões acerca dos aspectos específicos da química.

Para que isso seja possível, Erduran (2007) aponta que é necessário "orquestrar" o uso de conhecimentos declarativos e procedimentais do domínio da química. Além disso, considera a importância de se identificar os conhecimentos prévios dos estudantes acerca dos temas a serem trabalhados. Ainda, de acordo com Treagust e Chittleborough (2001), o professor de química desempenha um 
papel importante em relacionar as observações macroscópicas com as explicações no nível simbólico e representacional.

Apesar disso, as falas do docente P1 sugerem que ele tem como foco, nessa atividade, apenas os aspectos procedimentais envolvidos. Por exemplo, nesse caso, não se observam indícios de que o professor tenha estimulado os estudantes a estabelecerem relações entre teoria e prática, bem como não há menção sobre discussões acerca das práticas realizadas. Visto que seguem uma receita prédeterminada, a ação dos estudantes parece se restringir a questão manual e não cognitiva, mental. Nesse sentido o próprio docente apontou que o mais importante é o "lado prático".

P1: (...) você pode ver a parte teórica mas aí já vou direto na parte prática...

Hirayama: em termos de parte teórica (...)

P1: meu... é muito pouco tempo dois... aí eu passo muito rápido... eu tenho que falar em $\mathrm{Cl}$ ma daquilo que é prático... eu tenho que falar aquilo que é... ahn:: que tá na prática... tá vendo isso aqui... tá?... legal... aí acabou ( )

Com relação às atividades desenvolvidas na escola técnica, P1 apontou que realiza discussões com os estudantes. Contudo, conforme evidenciam as falas a seguir, tais discussões só ocorrem quando há algum erro nas respostas dos estudantes às atividades relacionados a experimentação.

Hirayama: (...) aqui ((na ETEC)) ou na::... ou no Estado - - principalmente aqui né? que você faz mais - - ...o que você costuma discutir... na parte experimental parte prática experimental?

P1: (...) hoje eu fiz a parte qualitativa... eles vieram fiquei dando visto tudo e aí quando estava errado falei "vamos ver" ( ) aí teve discussão "o que que seu grupo achou?" "ah não" ... "ah copiou errado?" "não o grupo todo fez" porque? aí pá:...:ra e discute (...)

Ainda com relação às características da experimentação em química, como visto anteriormente, P5 descreveu a realização de uma prática na qual os estudantes eram incentivados a realizar uma atividade característica da prática química: a classificação (Erduran, 2001, 2007; Lefèvre, 2012; Schummer, 1998).

P5: (...) eles têm que construir uma tabela (...) separar os indicadores... as cores (...) depois de tudo que ele fez... ele vai ter que me mostrar... por exemplo... índice de naftalina... na substância... ele é básico tem que cor? qual a substância que você então descobriu que eram básicas? a partir de que momento que você falou que era básica? por quê? tinha alguma substância que você usou que você tem essa noção? 
Portanto, a descrição de algumas aulas desenvolvidas pelos docentes revela que, de algum modo, eles procuram inserir a experimentação em sua prática docente. Contudo, apesar de certas atividades envolverem aspectos que podem favorecer a aprendizagem da ciência e sobre a ciência, de modo geral, o uso delas fica limitado à mera ilustração de fenômenos. Consequentemente, o potencial pedagógico da experimentação na formação do aluno, tendo como base essa perspectiva, fica restrito ao desenvolvimento de habilidades como observar, coletar dados e manipular materiais e reagentes que, embora sejam importantes e integrem a prática científica, exigem uma menor demanda cognitiva do que capacidades como a argumentação, a metacognição e a investigação (Hofstein et al., 2013).

Além disso, nenhum docente mencionou a preparação de situações de aprendizagem que podem ser usadas para retratar as características específicas da prática química autêntica, nas quais os estudantes sejam levados a elaborar hipóteses, criar modelos, discutir com os colegas, bem como comunicar e testar suas ideias. Também, nenhum deles apontou como objetivo explícito o ensino de noções a respeito da ciência e dos cientistas ou a promoção de reflexões acerca de aspectos relevantes do processo de investigação científica de modo geral - como a colaboração entre cientistas, a orientação teórica no levantamento de hipóteses, a natureza inferencial e criativa envolvida na interpretação dos fenômenos - e da experimentação química, em particular - como, por exemplo, a síntese como uma atividade característica dos químicos e o papel da instrumentação.

\subsubsection{Relevância}

De modo geral, para os sujeitos entrevistados, a experimentação no ensino de química é importante para aumentar o interesse pela ciência e comprovar as teorias vistas em sala de aula. Ademais, eles apontaram que, por meio de atividades experimentais, os estudantes podem construir conhecimentos, relacionar prática e teoria, bem como desenvolver habilidades manuais, de observação, e uma visão mais abrangente da química, percebendo-a em seu cotidiano.

Apesar de terem apontado o papel da experimentação na formação dos estudantes, P2 e P3 relativizaram a importância das atividades práticas. Para P2, o ensino de química envolve um conjunto de fatores e, por isso, considera que as experimentações, embora relevantes, não são imprescindíveis. 
P2: (...) eu não acredito na química só com experimento... sabe assim? é... é um conjunto de.: de fatores... a experimentação ela é importante mas ela não é... imprescindível...

De fato, é importante que a experimentação não seja incluída na prática pedagógica de modo estanque, mas deve ser relacionada com outras abordagens didáticas. Ainda assim, a concepção da professora expressa nessa fala pode levá-la a desconsiderar o potencial das atividades experimentais na promoção de determinadas capacidades e conhecimentos.

P3, ao comentar a respeito de uma aula que considerou boa, também externou sua opinião sobre esse tema. Para o docente, é preferível não realizar experimentos a utilizá-los apenas para comprovar empiricamente algum conteúdo visto previamente.

P3: para que a aula experimental?... para materializar... para concretizar o que ele não consegue abstrair (...) aula experimental expositiva pra você dizer o que ele tem que ver... aí eu digo vai dar azul... não deu azul... daí faz de conta que é azul (...) então não faz... entende? (...)

A opinião de P3 está em consonância com a de pesquisadores em ensino de ciências que criticam o uso da experimentação para confirmar teorias vistas em sala de aula. A esse respeito, Silva (2010) enfatiza a importância da abstração no desenvolvimento do conhecimento científico e o fato de que este é uma elaboração humana e, como tal, não pode ser obtido diretamente pela observação neutra de um determinado fenômeno.

P3 foi o único docente entrevistado que associou a experimentação à construção de conhecimento. De acordo com ele, as atividades práticas podem ser utilizadas para tirar dúvidas, realizar questionamentos ou fornecer informações.

P3: (...) é::: legal quando a prática vem para - - não para justificar um conceito - - mas talvez para construir... alguma coisa... tirar uma dúvida... levantar um questionamento e eu acho que mesmo que você use o experimento para abordar um tema novo... OU... que já esteja em andamento... eu... eu... o ideal para mim é que eles tirem do experimento algUMA informação... e daí algum conhecimento (...)

Hirayama: quais seriam os objetivos principal... o seu objetivo principal ao inserir essas atividades?

P3: (...) vou ser bem genérico... é construção do conhecimento (...) eu acho que é... é para construir conhecimento... de toda natureza inclusive... inclusive operacional né? o ideal seria... ter esses instrumentos aí... ter esses aparelhos... ter essas substâncias... vai... como você propõe achar isso? (...) como eu recolho um gás? está aí os materiais possíveis está aí 
está tudo aí como você faria? isso eu acho interessante e acho assim que é questão de construção de conhecimento... de pensamento (...)

O professor apontou ainda que exercitar o pensamento e estabelecer relações devem ser objetivos não apenas do uso do trabalho experimental, mas de quaisquer abordagens utilizadas no ensino de química.

Hirayama: (...) o que é importante que esse aluno desenvolva... por meio das atividades experimentais?

P3: (...) pensamento... pensar construir relacionar extrapolar (...) seja o que for... seja uma leitura... seja uma observação de algum fenômeno... seja... seja na aula... na aula... tradicional... seja numa videoaula... seja num... num gráfico

Hodson (1994) defende que as atividades experimentais devem ser parte integrante de um programa que tenha como principais aspectos: a aprendizagem da ciência, ou seja, o desenvolvimento de conhecimentos teóricos e conceituais; a aprendizagem sobre a ciência, ou seja, o desenvolvimento de um entendimento da natureza e dos métodos da ciência, bem como das complexas relações entre ciência, tecnologia e sociedade; e a prática da ciência, ou seja, o desenvolvimento de conhecimentos técnicos, éticos e outros sobre a investigação científica. Assim, de acordo com Hodson (1994), é importante que se reflita tanto sobre as diversas maneiras pelas quais as atividades práticas podem contribuir para se atingir esses objetivos quanto acerca dos modos alternativos e mais apropriados de se alcançar tal intento.

Nesse sentido, o fato de P3 ter atribuído as mesmas finalidades a diferentes estratégias de ensino pode levá-lo a não considerar como a utilização da experimentação no ensino de ciências pode ser mais eficaz para atingir determinados objetivos, em relação a certos assuntos, do que outras abordagens pedagógicas, como a leitura e a aula expositiva (Hofstein et al., 2013).

Conforme evidenciam as falas a seguir, para a maioria dos docentes entrevistados, um dos principais objetivos da experimentação é fomentar o interesse dos estudantes pela química e seu estudo.

Hirayama: (...) qual seria o objetivo do experimento nesse caso?

P1: para não afugentar da química

Hirayama: (...) você pensa em fazer uma (...) atividade experimental com qual objetivo (...)?

P4: para ver se desperta o interesse né?... você vê que tem:.... a porcentagem de pessoas 
que gostam de química já falei para você que é pequena né? (...)

Hirayama: por que você acha que é importante?

P5: ah é importante porque senão a gente não vai ter professor de química (...) você nunca vai escutar o aluno chegar e falar assim por exemplo "professora obrigada por tua aula eu vou fazer química" porque o que eu vejo é que a maioria não gosta de química

Atualmente, um dos principais desafios da educação é a falta de motivação dos estudantes (Corrêa, 2009). Tomando por base as ideias de proponentes da abordagem motivacional, Guimarães (2003) aponta que, na escola, um dos principais determinantes do envolvimento ativo no processo de aprendizagem é a motivação. Entretanto, em função da complexidade inerente à tarefa educativa, torna-se difícil se definir, de modo preciso, quais estratégias e temas têm o potencial de motivar os estudantes. De acordo com Corrêa (2009), apesar de estar relacionada com o engajamento ativo dos estudantes nas tarefas propostas e a qualidade da aprendizagem, a motivação é mobilizada nas relações sociais e varia de acordo com o contexto no qual os indivíduos estão inseridos. Desse modo, a discussão acerca da capacidade da experimentação em promover o interesse dos estudantes também envolve a consideração de diversas questões e perspectivas em relação a esse aspecto.

Para as docentes P2 e P4, a experimentação, por si só, pode aumentar o interesse dos estudantes pela química e a ciência. Segundo as professoras, isso decorre do fato de eles estarem realizando uma atividade diferente daquelas com as quais estão acostumados em seu cotidiano.

P2: (...) o experimento por si só eu acho que ele já é:.:: já é diferente... já::/já chama atenção... o sair da sala de aula já/já desperta o interesse pra eles né? fazer um experimento mais ainda... se eles saíssem então de avental branco então...

$---$

P4: (...) eu fiz uma sugestão... que de vez em quando (...) viessem pessoas que nos ajudassem com aula prática (...)

(...)

P4: cada aula os alunos fazerem uma coisa diferente para ver se em alguns despertam o interesse pela química... pela ciência (...)

P5, por sua vez, aponta que, ao participarem de atividades nas quais têm a oportunidade de manipular materiais e reagentes de laboratório, os estudantes passam a gostar mais da disciplina de química e, consequentemente, a prestar mais 
atenção às aulas, questionar mais sobre os conteúdos e elaborar ideias com base no que foi estudado.

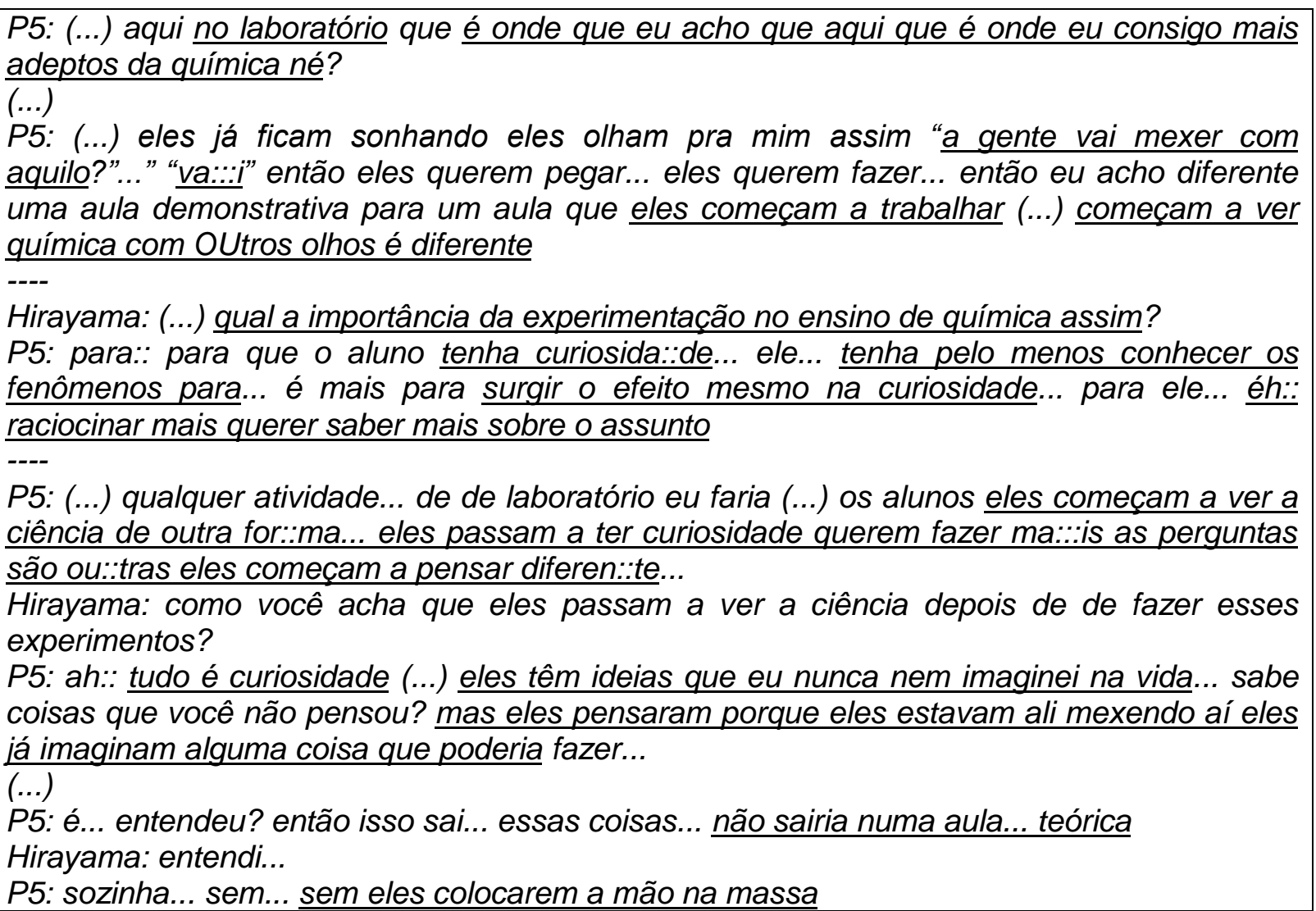

Hofstein e colaboradores (2013), em uma breve revisão acerca do potencial motivador da experimentação, apontam estudos os quais evidenciam que os estudantes preferem atividades experimentais por considerá-las menos aborrecedoras do que outras atividades escolares, como a escrita e a aula expositiva e, por isso, embora declarem gostar de práticas experimentais, não apresentam, necessariamente, interesse pessoal pela ciência e seu estudo. Além disso, apontam que a preferência por essas atividades diminui à medida que os estudantes vão progredindo nos anos escolares. Os pesquisadores concluem que o potencial da experimentação em promover uma atitude mais positiva em relação à química e à ciência depende da natureza do trabalho prático proposto, ou seja, do modo como as atividades são organizadas e dos desafios propostos.

Hodson (1994) considera que, frequentemente, não é a experimentação em si que atrai os estudantes, e sim a oportunidade de participar de métodos de 
aprendizagem mais ativos que permitam maior interação com os colegas e com o professor.

Nesse sentido, restringir o foco da atividade experimental à observação de instrumentos e fenômenos impactantes, ou mesmo a simples manipulação de materiais, conforme apontam os docentes P1, P2, P4 e P5 nas falas a seguir, seria contraproducente.

P1: (...) quando eu fiz o Estado (...) tinha um laboratório... hoje eles não têm eu mexia eu ficava vidrado em ver um termômetro ver vidrado em ver um mercúrio separado tudo

$----$

Hirayama: (...) qual (...) é a importância assim da experimentação do ensino de química? (...) P4: (...) quando eles veem mudança de cor:: gases efervescência qualquer coisa... pelo menos quando eles veem o que aconteceu querem entender um pouquinho mais

(...)

Hirayama: mas essa da geleca você acha que foi uma atividade boa?

P4: foi mas foi o estagiário que trouxe o material...

Hirayama: por que você acha que essa foi boa?

P4: porque eles acham diferente ver cor ver coisa diferente ver uma coisa que muda 0 estado físico... rápida né?

----

P5: (...) a única coisa que você consegue chamar atenção do aluno é se você fazer explodir alguma coisa e fazer pegar fogo...

(...)

P5: aí eles gostam... que nem do bicarbonato eu enchi a bexiga né? (...) a bexiga com... vinagre bicarbonato... ah aí acharam o máximo... disseram que foram em casa encheram um monte de bexiga para mãe ver pai ver não sei o que lá (...)

Hirayama: (...) com que objetivo você dá uma experimentação?

P2: (...) porque primeiro que eles gostam porque muda o ambiente... eles manuseiam coisas diferentes (...)LÁ ele manuseou... então assim... quando ele manuseia ele fica mais feliz... né? mais feliz do que quando ele vai simplesmente ao laboratório e visualiza né?... então assim... o manusear pra eles é interessante

De acordo com Hodson (1989), enquanto crianças pequenas se sentem motivadas quando manipulam equipamentos ou fazem observações, os jovens mantêm seu interesse por uma atividade quando esta envolve um estímulo cognitivo, como a investigação de ideias e a resolução de problemas. A esse respeito, Hofstein e colaboradores (2013) mencionam um estudo que comparou as atitudes de dois grupos de estudantes da mesma escola em relação ao laboratório de química. Um dos grupos desenvolveu atividades investigativas, enquanto o outro participou de práticas tradicionais, que envolviam a confirmação de teorias vistas em sala de aula. Segundo a pesquisa, os estudantes do grupo da investigação 
apresentaram maior motivação para a aprendizagem de química do que aqueles que realizaram experimentos mais convencionais.

Assim, experimentos com caráter comprobatório, trabalhados como mera ilustração, organizados como "receitas de bolos" e nos quais se realiza apenas a coleta de dados, podem transformar a motivação inicial dos estudantes de ensino médio em desinteresse. Ademais, embora os experimentos possam servir para mobilizar os alunos, restringir a sua função à motivação é limitar o potencial dessas atividades no processo de ensino e aprendizagem.

Outro objetivo da experimentação no ensino de química, segundo os docentes P1, P2 e P5, é permitir que os estudantes relacionem a prática com a teoria.

Hirayama: (...) quais são as principais características de uma boa atividade experimental?

P1: as características? é que.: o aluno consegue entender... para mim isso é o mais importante... o aluno entendeu

Hirayama: e entender principalmente o quê?

P1: a... teoria embasada na prática

P2: (...) se ele consegue fazer uma conclusão onde ele explique aquele experimento e relacione com a ideia do... daquela teoria... eu já estou satisfeita...

$----$

P5: o mais importante é isso é ele conseguir unir o que ele aprendeu comigo com o que ele tá vendo ali

(...)

P5: a prática com a teoria...

De acordo com Silva e colaboradores (2010) "a experimentação no ensino pode ser entendida como uma atividade que permite a articulação entre fenômenos e teorias" (p. 235). Em consonância com essa visão, Hofstein e colaboradores (2013) apontam que um dos papéis relevantes do trabalho experimental na disciplina de química é promover o desenvolvimento de relações entre observações e ideias científicas. Desse modo, assim como os docentes consideraram, incentivar os estudantes a estabelecer relações apropriadas entre os modelos curriculares e as observações macroscópicas favorece a compreensão do caráter tentativo e criativo da atividade científica, bem como da dependência entre observação e teoria.

Como considerado anteriormente, a articulação entre a prática realizada e os conceitos vistos em sala de aula somente é possível caso os estudantes já possuam conhecimentos mínimos com base nos quais possam elaborar hipóteses plausíveis 
para os fenômenos estudados, expor e discutir suas ideias, assim como explicar os resultados obtidos (Hodson, 1994; Hofstein et al., 2013).

No que se refere a essa questão, como sugerem as falas abaixo, P2 e P5 mencionam que uma das características mais importantes de uma atividade experimental é que os estudantes saibam os objetivos da experimentação. Ademais, apontam a importância de haver uma articulação entre o que foi trabalhado em sala de aula e as atividades práticas realizadas.

Hirayama: (...) quais são as principais características de uma boa atividade experimental? (...)

P5: (...) primeiro ele ele tem que saber... pelo menos ter ter uma informação do que vai acontecer...

(...)

P5: (...) né? não que... ele tem que saber o:: "ah eu vou misturar isso para isso mas o que eu quero ver?" entendeu? (...)

----

P2: eles têm que saber o objetivo daquilo que eles vão fazer lá... não pode simplesmente ir lá pra fazer qualquer coisa né? tem que estar relacionado com algum coisa do:.:/da sala de aula né? algum assunto que esteja trabalhando na sala se não não faz sentido também né? ahn:: e tem que ahn/de alguma maneira eu tenho que amarrar esse conteúdo com o objetivo que eu tinha na sala... eu tenho que trazer aquele experimento pra sala de aula (...)

Entretanto, não obstante tenha se referido favoravelmente a uma das condições que apoiam o estabelecimento de relações apropriadas entre os aspectos macro e microscópicos concernentes aos fenômenos estudados, P2, ao apontar outros objetivos para a experimentação, apresentou uma visão dicotômica entre teoria e prática que contribui para a disseminação de concepções ingênuas acerca da atividade científica. Nas falas abaixo, a docente apontou que um dos principais objetivos da experimentação é comprovar, pela prática, uma teoria vista em sala de aula.

Hirayama: (...) quais são os seus objetivos ao você inserir uma (...) atividade experimental $(\ldots)$ ?

P2: (...) comprovar alguma coisa alguma teoria que eu estou trabalhando... isso é condenado... muita gente condena né? mas é só para... para... para comprovar... alguma teoria... né? (...)

Hirayama: (...) o que você pretende que os estudantes desenvolvam mais ao trabalhar com atividade experimental? o que é mais importante nesse sentido?

P2: bom... o meu objetivo ali é que ele comprove uma ideia que eu estou passando né? 
A concepção de que a experimentação favorece a aprendizagem pois, por meio dela, é possível concretizar ou ilustrar as teorias elaboradas pela ciência é comum entre os docentes (Silva et al., 2010; Galiazzi et al., 2001). Para Silva e colaboradores (2010), de acordo com essa crença, o fenômeno observável seria somente uma demonstração experimental de uma verdade escondida na Natureza, descoberta pelo trabalho de mentes brilhantes. Contudo, conforme aponta Gonçalves (2005), as teorias não são comprovadas pelos experimentos, mas parcialmente amparadas por eles. O pesquisador aponta, tomando por base as discussões de Kuhn, que a escolha de teorias rivais não é feita somente a partir de critérios empíricos e que, mesmo quando há uma discordância entre os dados empíricos e uma teoria, esta não é abandonada. Desse modo, o uso da experimentação com o objetivo de comprovar teorias abordadas em sala de aula pode favorecer a apropriação por parte dos estudantes de uma visão distorcida acerca do empreendimento científico, a qual dificulta a compreensão da ciência como um construto humano, sujeito a diversos fatores.

P1 também apresenta uma concepção semelhante à de $\mathrm{P} 2$ com respeito às relações entre teoria e prática. Conforme sugerem as falas abaixo, embora tenha mencionado a relevância de se compreender a teoria com base na prática, 0 docente valoriza mais os aspectos práticos e fenomenológicos associados à experimentação.

Hirayama: (...) o que que você acha/o que é uma boa aula experimental... que elemento ela tem que ter assim?

$P 1$ : veja bem tem que ser fácil para ele enxergar (...)

----

P1: (...) toda parte prática (...) ela é concretizada... no teu cérebro... eu acho isso importante

P1 enfatizou que é mais importante que os estudantes compreendam a prática, pois, segundo suas palavras, "depois da prática vem a teoria”, ou seja, "a prática faz a teoria".

Hirayama: (...) o que ele tem que saber no final de uma aula de laboratório o que seria mais importante assim... pra esses que não... que vai ser químico (...)

P1: (...) ele tem que entender que a prática... toda prática tem a sua teoria eu mostro pra eles que eles têm que entender a prática porque depois da prática vem a teoria... e nunca antes... nunca é trocado... a teoria não faz a prática... mas é a prática que faz a teoria (...) 
Nas falas a seguir, ao ser questionado acerca da importância da discussão sobre os interesses da Alemanha na produção de amônia no início do século XX, P1 revelou a relevância que atribui à parte "prática" da experimentação e apontou que teorias "não levam a nada".

P1: (...) tenho certeza que você tem que fazer primeiro a parte prática... entende? (...) você... pode parar... a teoria... não leva... ni/ninguém a nada... nada a ninguém... então você tem que aplicar... faz o aplicativo... olha "vamos entrar na sala de aula... no laboratório e vamos tentar fazer isso"

Hirayama: (...) se você tivesse que reestruturar essa/essalessas atividades (...) ((sobre os motivos do interesse da Alemanha na produção de amônia e o contexto social, econômico e político na época, bem como as discussões sobre as demandas envolvidas na obtenção da amônia)) você ( ) de uma outra maneira?

P1: a:.: teria que fazer primeiro uma parte prática... entendeu?

Ademais, para o docente, o mais importante é que o estudante observe os materiais e fenômenos no laboratório.

P1: (...) na química é difícil você ficar... imagiNANdo coisas... imagina que...: vai ter uma reação química... não... VEja a reação química... é diferente

P1: é importante o aluno enxergar o verme::Iho o azul:: e a independente do que está acontecendo internamente... mas ele tem que enxergar uma reação química de precipitação... de corrosão

Tal noção desconsidera a possibilidade de haver diferentes interpretações para os mesmos dados, bem como o papel das teorias na definição dos problemas investigados, na condução dos experimentos, na orientação das observações a serem realizadas e na explicação dos fenômenos. Assim, a ênfase de P1 na parte prática pode levá-lo a transmitir aos estudantes uma concepção equivocada sobre o empreendimento científico, segundo a qual as leis e teorias científicas são derivadas de observações neutras e cuidadosas dos fenômenos da natureza (Gil-Pérez et al., 2001).

Ainda sobre estabelecer relações mais apropriadas entre observação, teoria e experimento, as Orientações Curriculares para o Ensino Médio - OCEM, de Ciências da Natureza, Matemática e suas Tecnologias (Brasil, 2006), apontam que

Tratar da inter-relação teoria-prática no ensino implica, pois, desmistificar o laboratório e imbricá-lo com o ensino concernente a vivências sociais da vida cotidiana fora da escola, aproximando 
construções teóricas da ciência (saberes químicos/científicos) com realidades próximas vividas pelos alunos, dentro e fora da sala de aula (p. 124).

No que tange a esse aspecto, os docentes P1 e P5 apontaram também que um dos principais objetivos da experimentação deve estar relacionado ao cotidiano dos estudantes, de modo que eles desenvolvam uma visão mais abrangente sobre a química. P1 ponderou que as atividades práticas devem permitir que os estudantes percebam de que modo a química está presente em seu dia a dia.

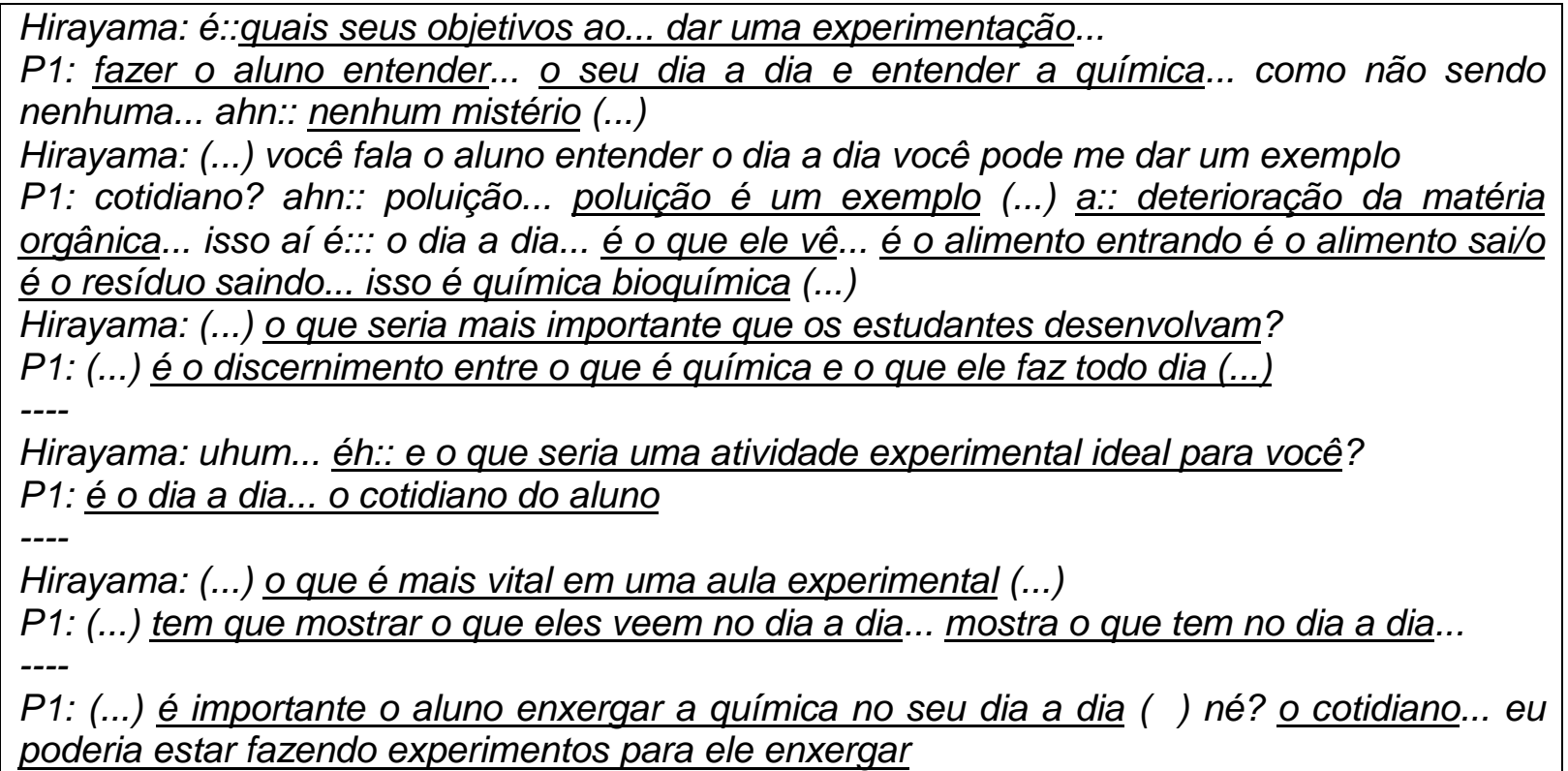

Ideia semelhante foi apresentada por P5. As falas a seguir sugerem que um de seus objetivos ao utilizar experimentos é promover uma visão mais abrangente acerca da química. Para ela, é importante que os estudantes identifiquem a presença da química "em vários lugares", de modo que eles se interessem mais por essa ciência.

Hirayama: (...) por que você escolheu trabalhar dessa maneira?

P5: para eles acharem que... não ficarem pensando que química é só no caderno... eles não conseguem ver esses conceitos (...)

Hirayama: é mais para eles saberem...

P5: que química tem em vários lugares para ele poder... aí eles começam... que nem orgânica eles começam a ver rótulo de tudo quanto é remédio procurando o nome que eles viram que é parecido entendeu? só curiosidade 
A discussão de questões relacionadas à realidade dos estudantes contribui para a superação de um ensino de química baseado na transmissão de conceitos isolados, bem como pode fomentar uma concepção mais autêntica a respeito do desenvolvimento da química e de seu caráter tecnológico. Contudo, o foco no que o estudante vê, ou seja, nos aspectos macroscópicos, pode limitar o potencial pedagógico da experimentação e, como foi visto, promover a visão de que é possível se compreender os fenômenos do cotidiano por meio dos sentidos imediatos.

Ademais, restringir a abordagem do cotidiano ao fornecimento de exemplos de produtos e processos químicos limita a compreensão acerca dos objetivos e métodos próprios da química. Uma das maneiras de se alcançar tal intento é planejar atividades experimentais que, dentre outros fatores, permitam a abordagem de questões sociais, culturais, políticas e econômicas associadas à química e à tecnologia.

Apesar disso, embora P1 tenha mencionado alguns assuntos ambientais, como a poluição, os docentes, de modo geral, não apontaram a relevância de se associar o trabalho experimental com a problematização das inter-relações entre a química, a tecnologia, a sociedade e o meio ambiente.

Portanto, apesar de apontarem a relevância da experimentação no ensino de química e citarem aspectos importantes relacionados a experimentação, tais como a articulação entre prática e teoria, os docentes não fizeram menção à importância de se preparar atividades que, em certa medida, se assemelhem à prática científica autêntica, por meio da quais os estudantes possam aprender química, sobre química e a prática da química (Hodson, 1994).

Além disso, nenhum sujeito entrevistado, ao descrever suas práticas pedagógicas e apontar a relevância da experimentação no ensino de química, mencionou, de modo espontâneo, a importância da preparação de atividades nas quais os estudantes sejam incentivados a refletir sobre as práticas realizadas com base em discussões epistemológicas atuais (Abd-El-Khalick, 2013).

Essa constatação está em consonância com a observação realizada por Hofstein e colaboradores (2013). Segundo eles, 
usado em uma comunidade científica é um objetivo especialmente importante de atividades de laboratório (p. 160).

Ao contrário, como evidenciam as falas a seguir, alguns professores emitiram opiniões negativas quanto à realização de discussões envolvendo aspectos específicos da prática química.

P2: (...) a primeira aí por exemplo... as funções dos experimentos na química...

Hirayama: aham

P2: eu não acho que para os meninos do ensino médio isso seja importante não (...)

P2: (...) o papel das teorias na experimentação em química (...) para o pessoal do ensino médio eu não acho importante também

----

Hirayama: (...) as funções dos experimentos... na química (...) as principais atividades dos químicos... o papel das teorias na experimentação em química... e o papel dos instrumentos da pesquisa QUÍmica... essas discussões (...) você acha que são relevantes para os estudantes (...)?

P3: $\underline{\text { não... do ensino médio não... eu não acho relevante }}$

Enquanto P2 não mencionou os motivos pelos quais desconsidera a importância de se discutir com os estudantes a função dos experimentos na química e o papel das teorias na experimentação química, P3 explicou que tais assuntos são muito específicos e, por isso, não os incluiria em sua prática pedagógica.

P3: (...) isso parece ser continuidade... isso não é fundamental para eles (...) quanto o ensino básico... não é fundamental... já foi dito as funções do experimento é feita a medida que você faz (...)

P3: (...) o papel das teorias na experimentação eu acho que é... é fato quando ele realiza né?... aí ele vai entender que ter um pouco mais de conhecimento científico vai ajudá-lo a pensar melhor no resultado do experimento... a olhar melhor o experimento... eu acho que isso está inerente... é embutido... acho que... não acho necessário (...)

Para P3, a mera participação em atividades práticas permite que os estudantes compreendam as questões sobre a experimentação química e o conhecimento científico. Ao fazer tal afirmação, P3 parece desconsiderar que os experimentos na ciência têm funções distintas dos experimentos realizados no contexto escolar, bem como a importância de abordagens explícitas e reflexivas no ensino da natureza da ciência.

Segundo Hodson (1994), embora seja mais comum que imagens sobre o trabalho científico sejam transmitidas implicitamente por meio de estratégias de 
ensino como a experimentação, para assegurar que os alunos tenham êxito na aprendizagem sobre a natureza da ciência, é necessário converter o que está implícito em explícito. A esse respeito, Abd-El-Khalick (2013) considera que as atividades investigativas são contextos ideias para auxiliar professores e estudantes a vislumbrarem a complexidade do empreendimento científico. No entanto, segundo ele, estudos têm constatado que a mera participação dos estudantes em tais atividades não tem, necessariamente, resultado em compreensões mais adequadas sobre a ciência e o trabalho dos cientistas. Por isso, o pesquisador defende a relevância de se promover com os estudantes discussões e reflexões explícitas acerca de aspectos sobre a natureza do conhecimento científico.

Para Schumacher e Reiners (2013), a alfabetização científica é favorecida quando os estudantes participam de ambientes autênticos de aprendizagem nos quais as características da química estão retratadas e são discutidas explicitamente. Dentre os aspectos químicos, os autores destacam a síntese como uma atividade distinta dos químicos, a ética, a linguagem e representação, bem como as funções e características das leis na química e na física.

Apesar disso, os docentes não apontaram o papel desses assuntos enquanto conteúdos curriculares relevantes para a formação dos estudantes. De modo geral, se referiram a eles somente como estratégias para sistematizar as ideias trabalhadas na atividade prática, favorecer o desenvolvimento de habilidades de leitura e escrita, bem como ajudar os estudantes a escolher de modo mais consciente a futura profissão.

Segundo P2, a abordagem de questões sobre a química é importante apenas como fechamento de uma atividade. Hirayama: o fato de um mesmo fenômeno ser interpretado de diferentes maneiras porque
cada grupo fez de um jeito... e a cooperação e colaboração do desenvolvimento cientifico
né? (...) você acha que essa discussão é importante pra formação dos estudantes?
$P 2:$ ah sim... eu acho sim... aliás todo fechamento de atividade se não for bem conduzido...
todo aquele trabalho parece que... ficou solto... ficou solto... fechamento de atividade ele é
fundamental... se tem uma discussão se tem uma escrita... melhor ainda... registro tem que
ter registro... né?
P2: ó... se a gente não voltar desde o princípio... por que nós fizemos aquele experimento?
porque a gente encontrou esse... éh.: essa resposta? por que as respostas dos grupos não
bateram? e tudo o mais... isso é importante assim... é uma construção... e na verdade
quando você está fazendo isso... né? esses fechamentos... você está mostrando também
assim... um trabalho... uma sistematização (...) 
Embora mencione aspectos importantes relacionados à experimentação, tais como a revisão dos objetivos propostos inicialmente e a discussão acerca dos resultados obtidos e das observações realizadas, a docente não fez nenhuma referência à relevância de se discutir, de modo explícito, determinadas características da construção do conhecimento científico.

P2 também aponta o papel da consideração de questões sobre a prática química como uma estratégia adequada para promover o desenvolvimento da capacidade de leitura e escrita de textos argumentativos.

Hirayama: (...) na ciência há apenas uma forma de interpretar um fenômeno né? éh:: depois perguntar se eles modificaram as explicações após a discussão né?

(...)

Hirayama: (...) os cientistas modificam suas explicações? (...) você acha interessante... você atribui importância? por quê? (...)

P2: (...) é importante sim... ó... e se você parar para observar cada um desses itens no final ele consegue construir um texto... quando ele faz essa relação uma coisa com a outra... no final ele consegue construir um texto... né? argumentar... né? (...)

----

P2: (...) porque... a gente precisa treinar esses meninos - - treinar parece uma palavra tão - mas precisa botar alguma coisa pra que eles aprendam a escrever... sabe assim? (...) quando eu falo assim "ah eu recebo meninos do primeiro ano do ensino médio que não são alfabetizados" (...) quando eu falo não alfabetizados é que não sabe construir uma: uma... defender uma ideia argumentar... escrever:: ler (...)

Novamente, a docente se referiu à argumentação como uma capacidade importante a ser fomentada nos estudantes. Capecchi e Carvalho (2000) consideram que essa capacidade permite que os estudantes tenham contato com habilidades fundamentais do processo de construção do conhecimento científico, como identificar evidências, reconhecer afirmações contraditórias e confrontar evidências com teorias. No entanto, embora tenha atribuído importância ao desenvolvimento da capacidade de escrever textos argumentativos, P2, contraditoriamente, apontou como perda de tempo uma atividade que sugere ações as quais contribuem para a implementação da argumentação em sala de aula, como permitir que os estudantes comuniquem suas ideias, exponham diferentes pontos de vista e negociem as explicações dadas em busca de consenso com base em critérios estabelecidos previamente (Vieira e Nascimento, 2009).

P2: (...) o experimento beleza... essa discussão ((comunicação das ideias acerca dos fenômenos, exposição dos diferentes pontos de vista, teste das concepcões e negociação em busca de um consenso)) aqui sobre o experimento eu não: não perderia muito tempo 
$\underline{\text { não... }}$

$---$

P2: ah... a atividade eu trabalharia sim... a queima eu trabalharia sim... né? a discussão eu não sei se eu ficaria tanto tempo aqui... né? na discussão em cima do experimento né?

Além disso, P2 não fez referência à importância da argumentação como parte da cultura científica, mas sim como uma capacidade a ser desenvolvida para preparar os estudantes para o ENEM.

P2: (...) a gente teve esse final de semana agora o... ENEM... né? onde é que pega o povo? na escrita... na leitura na interpretação e tudo o mais assim... se cada disciplina fizer isso... né? a gente tem meninos melhores no ENEM por exemplo... não só no ENEM né?

P5 também se referiu à relevância das discussões sobre aspectos da química apenas como uma estratégia para desenvolver as habilidades de leitura e interpretação de texto e não como um conteúdo a ser estudado e discutido com os estudantes.

Hirayama: (...) a leitura de artigos adaptados para o ensino médio envolvendo pesquisas recentes em química então pegar artigo de pesquisa né? (...) e aí a partir da leitura desse artigo... e de outras informações o professor discutiria né? no caso as funções dos experimentos na química... ia dizer para que serve o experimento na química né? as principais atividades dos químicos atualmente... o papel do...

P5: é eu daria normal lógico que daria eu acho MUito legal fazer isso é muito bom para o aluno ele vai ter... éh:: ele ele vai primeiro vai ajudar na leitura do nosso aluno do estado porque é triste...

Hirayama: tem dificuldade?

P5: mui::ta dificuldade em leitura... éh:: então já seria uma aula já para leitu::ra para compreensão de texto que também é outra dificuldade nossos alunos saem daqui... com essa deficiência de leitura $E$ interpretação não só devido à química ou a ciência entendeu?

Por isso, para ela, assuntos como a função dos químicos atualmente e o papel da experimentação na química apenas devem ser abordados a partir da curiosidade dos estudantes. Desse modo, P5 não considera a importância de se incluir tais questões em seu planejamento.

Hirayama: entendi talvez você discutisse mas talvez não por meio de um texto talvez? P5: não por meio de um texto é coisa do dia a dia e eu gosto desse jeito... eu gosto que partem né? partem deles tudo assim... eu não gosto de dar tudo de mão... perguntas feitas só quando é experimento mesmo (...)

P2 e P5 também apontaram a importância de se discutir com os estudantes as principais atividades dos químicos atualmente. Contudo, para elas, o principal 
objetivo de tal abordagem é fornecer informações que contribuam para que os estudantes escolham a futura profissão de modo mais consciente.

P5: (...) a função o que um químico faz ou para que serve um experimento... lógico que eles... eles têm que ter essa noção... por que é como ele vai escolher fazer uma coisa se ele não sabe para quê é aquilo... entendeu? (...)

----

P2: (...) as principais atividades dos químicos atualmente é/essa daí eu acho interessante (...)

P2: (...) eu acho importante porque:: (...) alalém (...) de você:: é é:: trabalhar...é:.:: os assuntos você ainda mostra a aplicação daquilo na/na vida profissional... onde é que eu vou trabalhar seu fizer essa área ou se eu se eu é:.... for trabalhar em alguma coisa que há necessidade da química... né? por exemplo... assim... muitos dos meninos tem... hum não tem ideia de quem faz farmácia usa tanta química

Assim como P5, P4 também associou alguns assuntos com o interesse dos estudantes em seguir uma determinada carreira. Ademais, a docente não fez nenhuma referência à importância de se discutir as características da química, mas considerou que algumas questões podem servir somente como fontes de informação para os estudantes entenderem alguns temas com os quais se deparam em seu dia a dia.

Hirayama: e essas discussões papel da instrumentação da química? o papel das teorias na experimentação? qual que é o que os químicos fazem hoje?

(...)

P4: eles não estão tão amadurecidos assim para perceber que poderia ( ) se interessar por determinado assunto e querer fazer uma carreira naquilo... difícil viu? tinha um:: tinha menino que... que... estava no segundo ano ele já queria... fazer biologia porque ele queria trabalhar com genética sabe? (...) uma coisa que despertou interesse dele ele já... "não... isso aí eu me interesso eu queria saber tudo sobre aquilo"

$----$

Hirayama: no caso dessas discussões aqui por que você acha que ela seria importante para os estudantes ahn:: do ensino médio?

P4: nanotecnologia? ah... eles ouvem falar né? então pelo menos vão ter uma ideia do que que seja né? é uma coisa... eles nem sabem o que que significa direito... nem que seja a nível de informação básica isso vai... ser importante para eles (...)

Ainda, segundo P1, a discussão acerca do papel dos instrumentos na química é relevante em função do uso de equipamentos em laboratórios e indústrias.

P1: o papel dos instrumentos é muito importante... hoje em dia... os laboratórios... a maioria dos laboratórios... não trabalham... é com... pela via úmida trabalham mais pela... é... por equipamentos e isso tem feito com que a indústria.... ele.: evolua... e vá mais rápido né? ahn:: então a parte de equipamentos tem que ser muito bem colocada 
Nesse sentido, ele também parece se referir à preparação dos estudantes para uma possível carreira na área científica, e não à compreensão acerca de características peculiares relacionadas à química.

O Quadro 05, a seguir, apresenta uma síntese das concepções e práticas dos sujeitos entrevistados no que se refere à abordagem do tema experimentação. 


\begin{tabular}{|c|c|c|c|}
\hline \multirow{2}{*}{ Sujeitos } & \multirow{2}{*}{ Prática docente } & \multicolumn{2}{|r|}{ Relevância } \\
\hline & & Atividades experimentais & Discussões sobre experimentação \\
\hline P1 & $\begin{array}{l}\text { Em geral, realiza práticas apenas na escola técnica. } \\
\text { - Solicita aos alunos da rede estadual que realizem práticas } \\
\text { Exemplos: práticas nas quais os alunos manipulam } \\
\text { reagentes e materiais, cujos focos são o desenvolvimento de } \\
\text { habilidades de observação e manipulação de materiais e } \\
\text { reagentes. }\end{array}$ & $\begin{array}{l}\text { Motivar os estudantes. } \\
\text { Derivar teoria da } \\
\text { prática. } \\
\begin{array}{l}\text { Compreender } \\
\text { cotidiano. }\end{array}\end{array}$ & $\begin{array}{l}\text { - Considera importante discutir o papel da } \\
\text { experimentação para preparar o estudante } \\
\text { para uma eventual carreira na indústria } \\
\text { química. }\end{array}$ \\
\hline P2 & $\begin{array}{l}\text { - Em geral, realiza atividades demonstrativas na escola onde } \\
\text { atua. } \\
\text { - Exemplos: atividades que permitem o desenvolvimento das } \\
\text { habilidades de observação, coleta de dados, elaboração de } \\
\text { tabelas e gráficos. } \\
\text { - Têm como foco principal a introdução de conceitos ou } \\
\text { "mostrar" na prática os aspectos teóricos vistos em sala. }\end{array}$ & $\begin{array}{l}\text { Motivar os estudantes. } \\
\text { Comprovar teorias. }\end{array}$ & 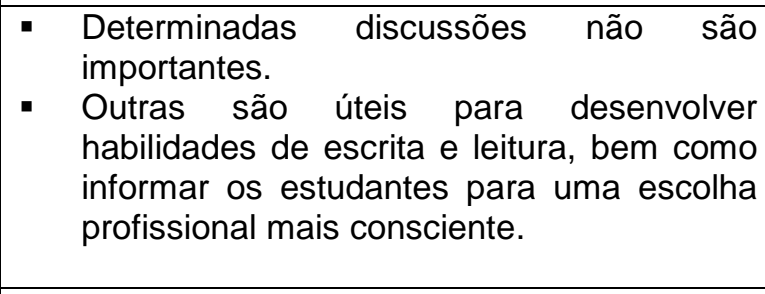 \\
\hline P3 & $\begin{array}{l}\text { - Em geral, não realiza atividades experimentais na escola em } \\
\text { - } \quad \text { Sue trabalha. } \\
\text { Solita aos estudantes que realizem práticas em suas casas. }\end{array}$ & $\begin{array}{l}\text { Construir } \\
\text { conhecimentos. }\end{array}$ & $\begin{array}{l}\text { Discussões direcionadas sobre a prática } \\
\text { química não são fundamentais. }\end{array}$ \\
\hline $\mathrm{P} 4$ & $\begin{array}{l}\text { Em geral, realiza demonstrações na escola onde atua. } \\
\text { - Exemplos mencionados: atividades que permitem o } \\
\text { desenvolvimento das habilidades de observação e coleta de } \\
\text { dados. } \\
\text { Têm como foco principal promover a aprendizagem por meio } \\
\text { da observação dos fenômenos. }\end{array}$ & - Motivar os estudantes. & $\begin{array}{l}\text { - Determinadas discussões devem partir do } \\
\text { interesse dos estudantes em seguir uma } \\
\text { carreira na área. } \\
\text { - Alguns assuntos servem como fontes de } \\
\text { informações. }\end{array}$ \\
\hline P5 & $\begin{array}{l}\text { - Comumente, realiza atividades com a participação ativa dos } \\
\text { estudantes. } \\
\text { - Exemplos: atividades que permitem o desenvolvimento de } \\
\text { habilidades de observação, manipulação de materiais e } \\
\text { reagentes, coleta de dados e classificação. } \\
\text { - Têm como foco principal "mostrar" na prática aspectos } \\
\text { teóricos, e promover a aprendizagem por meio da } \\
\text { observação dos fenômenos. }\end{array}$ & $\begin{array}{l}\text { Motivar os estudantes. } \\
\text { Identificar a química no } \\
\text { cotidiano. }\end{array}$ & $\begin{array}{l}\text { - Determinadas discussões devem partir dos } \\
\text { estudantes. } \\
\text { - Algumas contribuem para o } \\
\text { desenvolvimento de habilidades de leitura, } \\
\text { bem como para informar os estudantes } \\
\text { para uma escolha profissional mais } \\
\text { consciente. }\end{array}$ \\
\hline
\end{tabular}

Quadro 05: Quadro-resumo das concepções e práticas dos sujeitos entrevistados acerca do tema Experimentação. 
3.1.4. Desenvolvimento histórico

\subsubsection{Prática docente}

Os professores investigados, ao descreverem suas práticas e indicarem seus principais objetivos no ensino dos temas discutidos durante as entrevistas, apontaram que costumam considerar com os estudantes alguns assuntos relativos à história da ciência.

P1 mencionou que aborda o tema alquimia com os estudantes da escola técnica onde atua, conforme sugerem as falas a seguir.

Hirayama: aquela parte histórica... você costuma dar?

P1: (...) toda parte ali da:.: alquimi:.:a... tudo... lá ((na escola estadual)) não dá tempo... aqui ((na escola técnica)) até a gente fala para o primeiro ano

Segundo os PCN+ Ensino Médio - Orientações Educacionais Complementares aos Parâmetros Curriculares Nacionais (Brasil, 2002), esse tema pode ser trabalhado pelo docente de modo a favorecer o desenvolvimento da capacidade de reconhecer e compreender a ciência e tecnologia químicas como construtos humanos, sujeitos a múltiplos fatores. Para alcançar esse objetivo, Porto (2010) aponta a importância de se incluir, no ensino de química, discussões acerca das interações entre ciência, tecnologia e sociedade no decorrer da história.

Com relação a esse aspecto, ao comentar como abordam equilíbrio químico, as professoras P4 e P5, apontaram que costumam relacionar o contexto histórico com o desenvolvimento do processo Haber-Bosch de obtenção de amônia.

P4: (...) conto para o pessoal aqui eles não estavam só preocupados só com nitrato para... alimentação das pessoas... e fertilizante não isso é para fazer... isso é para fazer... fazer pólvora... né? na época da guerra eu falo nitrato é para fazer guerra para fazer pólvora (...) ----

P5: (...) eu contei uma parte da história... né? de história mesmo da época da segunda que:::rra do problema de chegar... para eles poderem ter uma noção... da importância que era fabricar... né?

----

P5: (...) eu fiz esse comentário com os alunos da minha sala (...) porque tinha que sair do Chi::le... a dificuldade que estava na época (...) então eu dei uma aula de história antes de começar com isso daqui... para eles terem... éh... eu queria que eles tivessem assim... pelo menos o porquê aquilo estava sendo feito...

P5: (...) porque que teve essa preocupação:: em se fazer a síntese da amônia e aí depois como é que tudo isso foi estudado 
Conforme evidenciam as falas acima, P4 apontou que considera com os estudantes alguns fatores que influenciaram a busca por um processo economicamente viável para a síntese industrial da amônia. P5 mencionou a abordagem sobre as dificuldades de se obter compostos nitrogenados no período anterior ao desenvolvimento do processo Haber-Bosch, e a importância de se produzir amônia para a sociedade da época.

Assim como P4 e P5, o docente P3 também apontou que procura considerar com os estudantes a influência do contexto histórico no desenvolvimento da química orgânica.

P3: (...) eu faço éh:: pontual... tipo... quando começa química orgânica... que você fala... do impedimento filosófico do desenvolvimento da química orgânica... né? por que que desenvolve? demora a desenvolver? (...)

A abordagem dos aspectos apontados por P3, P4 e P5 favorece a superação de uma visão descontextualizada, aproblemática e ahistórica acerca da ciência, que ignora a compreensão dos modos pelos quais o empreendimento científico e tecnológico tem sido afetado pelas demandas e expectativas sociais em diferentes momentos históricos, bem como desconsidera os problemas que originaram os conhecimentos e o desenvolvimento de processos (Cachapuz et al., 2005).

Os sujeitos entrevistados também fizeram menção ao trabalho com questões históricas ao descreverem de que modo abordam os modelos atômicos em sala de aula. De acordo com as falas a seguir, uma das principais preocupações dos docentes P2, P3 e P4 é evidenciar aos estudantes a provisoriedade dos modelos e das teorias da ciência.

P2: (...) meu professor falava (...) uma teoria ela pode mudar né? ela é suscetível a dúvidas né? a incertezas e tal... pode mudar (...) e eu falo a mesma coisa (...)

$---$

P3: apresentar modelos as mudanças dos modelos... especificamente nisso (...)

----

P3: (...) a gente trabalha com modelo de Dalton... diz "olha esse não é o último modelo esse modelo não explica tudo mas ele serve aqui... existe outro"

----

P4: (...) contei algumas descobertas que foram feitas e que as ideias foram mudando ao longo do tempo depois que se estabeleceu uma teoria (...) falo assim "a gente não sabe se daqui dez vinte anos tudo isso que vocês estão aprendendo não vale nada... pode ser que mude tudo" 
Segundo Bastos (1998), um dos principais problemas da história da ciência veiculada no ensino é o estímulo à noção de que os conhecimentos científicos atuais são verdades imutáveis. Os PCN (Brasil, 1999) apontam que "não se pode simplesmente aceitar a ciência como pronta e acabada e os conceitos atualmente aceitos pelos cientistas e ensinados nas escolas como 'verdade absoluta'” (p. 31). Desse modo, a consideração acerca dos diferentes modelos atômicos no decorrer da história, e a ênfase no caráter provisório dos conhecimentos científicos, favorecem o desenvolvimento de concepções mais adequadas sobre a ciência e o trabalho dos cientistas. Para isso, é importante que a abordagem histórica ultrapasse a mera menção de datas, nomes e curiosidades acerca da vida dos cientistas e permita ao estudante a compreensão sobre o processo complexo de construção da ciência. Segundo Porto (2010), tal entendimento pode ser alcançado por meio do estudo de episódios históricos que permitam a reflexão e discussão sobre como os cientistas trabalham, suas motivações e as relações que estabelecem com a comunidade científica. No que tange a essas questões, as docentes P2, P4 e P5 teceram algumas considerações.

P4 mencionou que, por meio de um vídeo, aborda com os estudantes os experimentos de espalhamento de partículas alfa envolvidos na elaboração do modelo atômico de Rutherford.

P4: (...) eu passei (...) eu tenho DVD que eu comprei da... grandes descobertas da ciência (...) mostra:: bem... tem inclusive... aquela... o segundo ano que fala como que foi $\underline{a}$ descoberta do próton aquela (experiência) do::.: da folha de ouro... tem aquilo... em desenho animado direitinho em detalhes

Entretanto, a professora não se referiu a discussões de características importantes da ciência relacionadas a esse episódio - tais como o fato de Rutherford ter elaborado seu modelo atômico para responder às questões levantadas a partir dos experimentos de espalhamento de partículas alfa, a importância das contribuições de Geiger e Marsden e a influência de outras ideias na elaboração do modelo atômico de Rutherford. Sua principal preocupação parece residir na compreensão dos detalhes envolvidos no experimento da "folha de ouro".

P5 mencionou que considera com os estudantes as motivações dos cientistas e seus objetivos ao elaborar os modelos. Entretanto, a docente não fez nenhuma menção à colaboração e à cooperação envolvidas nesse processo. 
P5: então... eu falo... por exemplo... quando teve Rutherford e Bohr... (...) eu falo qual era a intenção que ele tinha... né? o que ele queria fazer... e como ele se programou e porquê que deu tudo diferente do que ele imaginava (...)

Já P2 se referiu à abordagem sobre a dimensão coletiva da ciência, ou seja, ao fato de a construção de modelos ser resultado do trabalho de vários pesquisadores e da busca dos cientistas pela validação de suas investigações.

P2: (...) entro na importância dos modelos (...) né? e aí... quem criou isso? né? quem pensou nisso? quem é que está por trás disso? né? (...) a importância da academia nessa história... e quando eu falo da academia eu estou me referindo assim a todas as pessoas que de alguma maneira trabalham para que (...) esse nosso dia a dia aconteça né? (...)

P2: (...) quando eu comento com eles assim "pensa... Dalton ele ele teve que criar um modelo... ele teve que criar um modelo e convencer alguém" quem era esse alguém? era a comunidade científica (...)

P5 ainda mencionou que considera com os estudantes o caráter inferencial da ciência, assim como a diferença entre hipóteses e teorias ao trabalhar com os modelos atômicos em sala de aula.

P5: (...) quando eu vou falar sobre Dalton... que era para deixar bem claro que naquela época não tinha como eles ver um átomo... não tinha como... ele foi dando hipóteses de como SeRIA aquilo ali e dali surgiu a teoria $---$

P5: (...) eu estou falando sobre as teorias atômicas... e aí vai... vai aparecendo as coisas... aí eu mostro a diferença da teori::a né? para... eu falo o que é uma teoria o que vem a ser uma hipótese como é a conclusão:: porquê que pensa nisso

Alguns sujeitos entrevistados apontaram também a consideração de questões históricas relacionadas à elaboração da tabela periódica. P3 e P4 mencionaram que se preocupam em mostrar aos estudantes a existência de outros sistemas de classificação além daquele desenvolvido pelo químico russo Dimitri Mendeleev.

P3: (...) eu apresento... eu faço... de alguma maneira eu faço essas coisas... "essa é a tabela que todos encontram... será a primeira? é a única? de quando é? (...)"

P4: (...) mas nem que seja u::mas... pinceladas disso eu mando fazer um... trabalho de pesquisa sobre esse tema para eles se aprofundarem... porque aqui só fala do Mendeleev mas tem outros também... até chegar... na... na tabela periódica atual tem várias... várias tentativas né? 
Abordar, de modo adequado, a complexidade envolvida no processo por meio do qual a tabela periódica pôde ser elaborada contribui para a formação dos estudantes, pois permite reflexões acerca das "tentativas de classificação, escolha de critérios, aceitação ou não pela comunidade científica, fecundidade de propostas inovadoras, disputas de prioridade etc." (Leite e Porto, 2015, p. 584).

P4 e P5 também mencionaram que costumam comentar com os estudantes detalhes a respeito de como Mendeleev conseguiu construir a tabela periódica a partir dos dados disponíveis na época.

P4: (...) falar do Mendeleev a::: como é que ele chegou a... naquela época ( ) não tinha sido descober/não não não se trabalhava com eletricidade e não tinha sido descoberta nenhuma partícula do átomo e:: até onde ele conseguiu chegar só com massa né? como ele conseguiu? os conceitos que ele fez de semelhanca de propriedade e de massa para fazer essa primeira tabela (...)

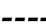

P4: (...) conto lá para eles que o:: Mendeleev tinha ideia fixa lá que ele achava que ele tinha que organizar... todos os dados a respeito dos... elementos que já tinham sido descobertos... que ele tinha insônia... - - você sabe disso né?- - que ele ficava colocando na parede da casa dele as coisas assim e depois ele muda (...) como é que ele foi montando né? (...) ele colocava em pequenos quadradinhos e montou a tabela (...)

P5: (...) o que a gente conversa mesmo já faz parte mostrar como que foi a evolução como é que ele ((Mendeleev)) pensou tudo (...)

Tal abordagem favorece a compreensão acerca do papel da imaginação e criatividade na construção do conhecimento científico. No entanto, para proporcionar uma visão mais abrangente acerca do processo de elaboração da tabela periódica, a discussão não deve ficar restrita ao trabalho individual de Mendeleev. É importante considerar também outros aspectos relevantes envolvidos, como o tempo necessário para se chegar à versão final da tabela, os objetivos do trabalho e os diferentes modos de lidar com os obstáculos surgidos (Leite e Porto, 2015).

P2 mencionou que incentiva a discussão sobre os motivos pelos quais a classificação de elementos químicos criada por Mendeleev foi mais aceita pelos químicos e se tornou mais conhecida.

P2: (...) porque será que aquela tabela a circular a espiral ela não foi para frente assim... ela está existe... mas todo mundo acaba usando essa do::quadrante aí do quadriculado aí... por quê?... né? pela praticidade mesmo né? e.:ssa quadriculada é muito mais fácil do que aquela espiral... né? 
Não obstante a consideração dessas questões permita aos estudantes vislumbrarem de que maneira diferentes fatores interferem na aceitação de uma determinada ideia científica, a professora apresentou uma visão estreita a respeito do assunto, segundo a qual a utilização preferencial da tabela na chamada "forma longa" ocorre apenas em função de sua praticidade. Tal concepção pode levá-la a não se aprofundar nas questões que explicam porque a classificação elaborada pelo químico russo foi mais bem-sucedida do que aquelas propostas por outros cientistas.

Além de mencionarem, de modo sucinto, como buscam inserir, em sua prática pedagógica, questões sobre a história da ciência, os docentes entrevistados apontaram também algumas estratégias que utilizam para desenvolver esse trabalho.

Um dos modos de se trabalhar com aspectos históricos em sala de aula, segundo P1, é solicitar aos estudantes uma pesquisa acerca dos cientistas laureados com o prêmio Nobel.

P1: (...) eu dei um trabalho para eles... pesquisarem... o trabalho do Svante August Arrhenius do prêmio Nobel (...) dei o site ( ) o site é esse nobelprize.com... "vocês vão pesquisar... eu quero saber do... Arrhenius... quando é que ele ganhou o prêmio e qual foi... qual foi o... o tema dele que fez ganhar foi sobre ácidos... ou foi um outro tema?" (...)

Araújo e Baldinato (2015) apontam que a consideração das palestras dos ganhadores do prêmio Nobel, por serem acessíveis e trazerem detalhes das motivações e dificuldades dos cientistas, assim como do contexto no qual o trabalho científico foi desenvolvido, pode ajudar a promover uma compreensão mais abrangente a respeito das relações entre os conhecimentos químicos e questões sociais, econômicas, históricas, políticas e ambientais, contribuindo, assim, para a superação de determinadas concepções inadequadas acerca da ciência e tecnologia. Apesar disso, embora não tenha descrito em detalhes como desenvolveu a atividade mencionada, P1 indicou que pediu aos estudantes apenas para constatarem a data em que Arrhenius recebeu o prêmio e o motivo pelo qual foi agraciado. No exemplo fornecido não há nenhuma indicação acerca da abordagem de aspectos do trabalho do cientista que evidenciassem as suas motivações e limitações, as teorias e hipóteses que orientaram a sua investigação, bem como o contexto no qual suas ideias emergiram. 
Outra estratégia, citada pelos docentes P1, P2 e P4, é a utilização de vídeos que apresentem os acontecimentos históricos associados ao desenvolvimento das teorias e modelos científicos.

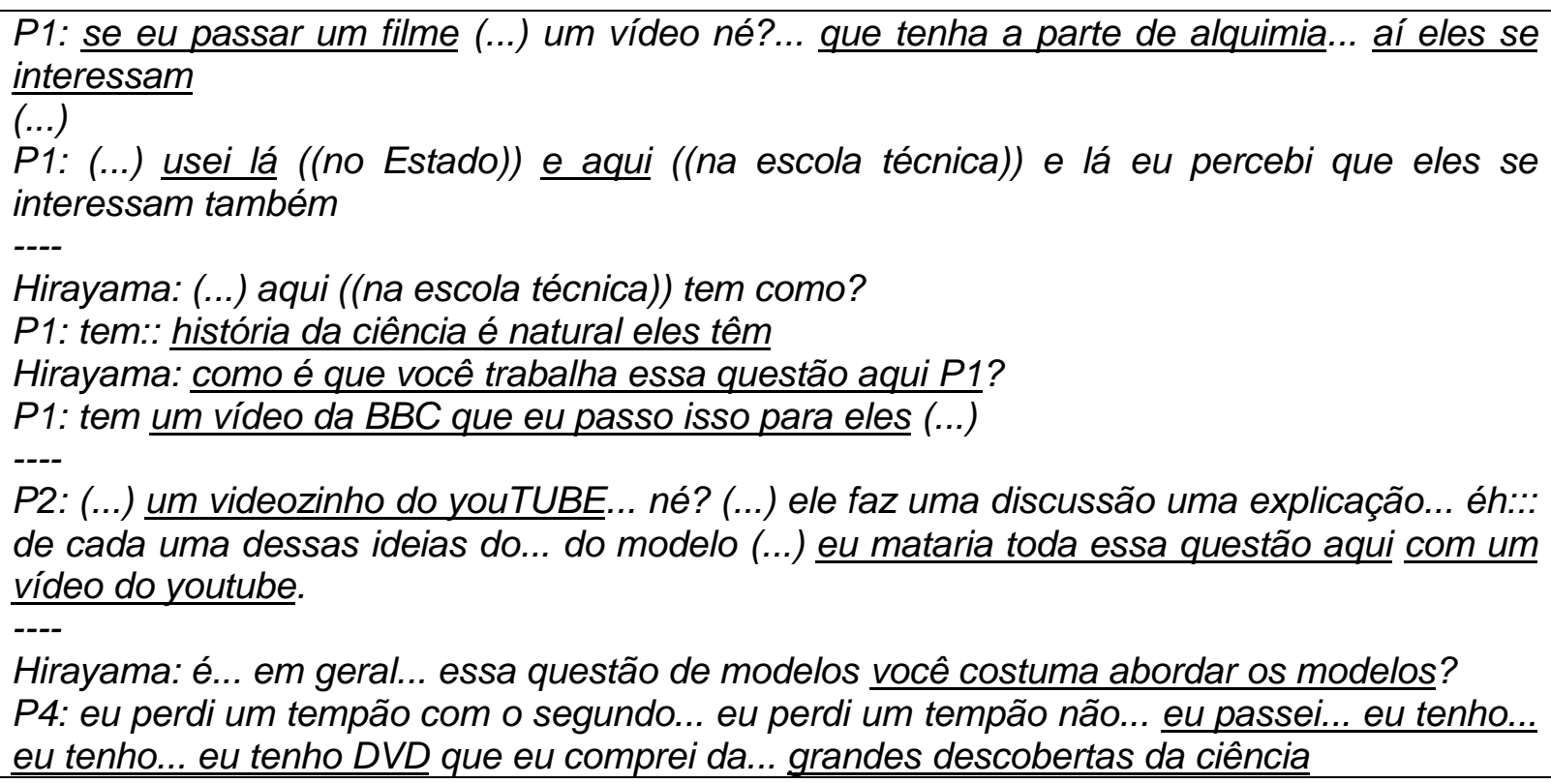

Arroio e Giordan (2006) apontam que o uso adequado de recursos audiovisuais no ensino de química pode organizar as atividades didáticas, motivar a aprendizagem e favorecer o desenvolvimento da competência de leitura crítica acerca do mundo. Nesse sentido, a apresentação de vídeos sobre episódios históricos pode contribuir para fomentar reflexões acerca da ciência, do trabalho dos cientistas e das relações entre ciência e sociedade no decorrer da história. Entretanto, nos exemplos fornecidos pelos docentes, não se nota nenhuma preocupação em abordar com os estudantes aspectos da natureza da ciência, como as motivações dos cientistas, as influências sociais no trabalho científico, bem como as controvérsias envolvidas na construção da ciência.

Embora tenha afirmado que utiliza vídeos para a abordagem de temas como a alquimia e o flogístico, o docente $\mathrm{P} 1$, ao descrever sucintamente como trabalha com esse recurso, destacou apenas aspectos dissociados da abordagem histórica, como procedimentos experimentais que não poderiam ser realizados num laboratório.

P1: (...) o vídeo foi MUlto bem produzido... você consegue trabalhar com eles... você consegue parar e falar "olha, tão vendo aqui"... o cara pega e coloca três luvas para poder 
enfiar a mão no mercúrio e mostra coloca um pedaco de parafuso e mostra sobre a densidade do mercúrio do parafuso de aco ali num vai pro fundo... entende? então são coisas que a gente jamais:: teria condições de fazer isso em um laboratório... onde eu vou arrumar mais ou menos uns $500 \mathrm{~mL}$ ou até 1 litro de mercúrio entendeu

P2 também não fez nenhuma menção à relevância de se considerar com os estudantes algumas características da ciência, ao destacar os motivos pelos quais trabalha ou trabalharia com recursos audiovisuais. A docente enfatizou somente a rapidez e o visual chamativo dos vídeos.

\footnotetext{
Hirayama: por que você faria dessa forma?

P2: acho que é mais rápido é visual tem música (...) mês passado eu trabalhei com ele né? $(\ldots)$

P2: (...) todo livro que você pega... quando ele vai explicar do... Dalton... ele fala da:.: da bola de bilhar

$(\ldots)$

P2: (...) o vídeo ele já começa... uma menina jogando bilhar... né? então ela pega o bilhar e tal... então já situ::a... já ambienta a... a a a história naquele espaço e depois ele vai descrevendo pegando cada uma das histórias aí... e é MUlto bacana... no final... isso eu posso te dizer que isso esse eu testei... né?

P2: (...) no final... eles conseguem mostrar a evolução dos modelos por esse vídeo do youtube... né? quando eles fazem essa leitura aqui eles associam lá com o vídeo do youtube... o vídeo deve demorar acho que uns sete minutos

$(\ldots)$

P2: é uma coisa bem rápida e mUlto didático né? então eu usaria esse mecanismo... eu acho que seria... bem... bem melhor... porque por exemplo ó... esse modelo das bolinhas aqui... isso é interessante... mas com animação fica mais bonito
}

Assim como os professores P1 e P2, ao descrever o seu trabalho com vídeos em sala de aula, P4 também não destacou nenhuma questão referente à natureza do conhecimento científico.

P4: (...) véspera de feriado... vem menos alunos (...) como você não vai dar uma matéria... a matéria proposta que você vai ter que repetir depois na aula porque metade da sala não veio aí você pode passar uma coisa diferente

(...)

P4: eu costumo fazer isso... eu costumo guardar ter algumas coisas guardadas assim algum vídeo alguma coisa... nessas ocasiões eu passo

Hirayama: e geralmente esses vídeos são sobre o quê?

P4: eu passo lá do modelo que eu falo de modelo atômico... de história da eletricidade... de química que tem pouca coisa né? da pilha... tem um que fala ( ) passa a ideia da pilha

Ademais, a professora afirmou que utiliza recursos audiovisuais apenas em ocasiões nas quais há poucos estudantes em sala de aula. Não houve menção à preparação de atividades didáticas por meio das quais eles pudessem estudar 
episódios históricos e discutir a respeito de características peculiares relacionadas à ciência. Desse modo, para P4, a abordagem de algumas questões envolvendo a história da ciência não é fundamental para a formação integral dos estudantes, servindo apenas como algo complementar e secundário.

Além da utilização de vídeos, P1 citou ainda uma outra estratégia para abordar a história da ciência: a exposição, por parte dos estudantes, de fatos históricos.

P1: (...) eu tenho uma aula e os alunos vão mostrar a história da química... eu passei pra eles de sessenta em sessenta anos... são oito grupos que vão me dá quinhentos anos quinhentos anos de história da química... desde a alquimia até 2013

As falas de $\mathrm{P} 1$ sugerem que sua preocupação precípua não é promover a compreensão acerca da complexidade envolvida na construção dos conhecimentos científicos, e sim considerar com os estudantes muitos anos da história da química, o que revela uma concepção enciclopédica e acumulativa da história da ciência.

No decorrer das entrevistas, assim como P1, os docentes P2 e P4 também apresentaram concepções equivocadas acerca da construção da ciência que podem favorecer o desenvolvimento de visões distorcidas por parte dos estudantes.

Embora tenham se referido à consideração do caráter provisório do conhecimento científico ao mencionar o trabalho pedagógico com modelos atômicos, as docentes P2 e P4 apresentaram uma perspectiva continuísta e acumulativa a respeito do desenvolvimento científico, segundo a qual as teorias e modelos científicos se aperfeiçoam progressivamente no decorrer da história, sendo, portanto, melhores do que os conhecimentos do passado.

P2: (...) quando tem a:: adapta/adaptação não... a melhoria... eu sempre falo que é uma melhoria né? de Bohr pra Rutherford

$----$

P4: (...) foi sobre.: modelo atômico mesmo... como a ciência evoluiu com o tempo... lá o papel da/da/da lá eles eram pensadores né? não tinham experiência nenhuma depois quando veio a experiência como é que se contribuiu... para melhoria... como é que demorou tanto tempo para chegar a uma coisa

P2 ainda apresentou a ideia de que a ciência evolui de modo linear em função do trabalho de cientistas geniais. 
P2: (...) você não tem ideia de nada... do que a matéria é formada... de repente chega alguém e te convence que... tenta provar para você que tudo é feito lá de... alguma coisa né? indivisível mas que... aí vem o outro e fala assim... "não mas essa parte indivisível ainda tem divisões" né? aí vem outro e diz... "não mas nessa parte indivisível ainda tem camadas" né? (...)

$----$

P2: (...) se você parar para pensar que os modelos na ciência alguém teve que paRAR... $\underline{e}$ construir um modelo pra explicar uma ideia que ELE está defendendo... esse cara tem que ser especial... né? criar modelos para justificar uma... para argumentar... para explicar aquilo que você está defendendo... é muito difícil mesmo... você tem que ter uma cabeça especial para isso... né? (...)

P2: (...) então eu digo que não são mentes comuns são mentes especiais mesmo (...)

A disseminação de tal concepção no ambiente escolar pode dificultar a identificação dos estudantes com a atividade científica e, assim, os afastar do estudo da química, visto que, de acordo com essa visão, apenas pessoas especiais e geniais poderiam participar da construção do conhecimento científico.

\subsubsection{Relevância}

Os sujeitos entrevistados mencionaram quais questões devem ser abordadas ao se incluir assuntos históricos nas aulas de química, e os motivos pelos quais essa abordagem é importante para a formação dos estudantes.

Conforme sugere o trecho a seguir, ao tratar do tema alquimia na escola técnica onde atua, P1 considera relevante se abordar com os estudantes como os alquimistas pensavam e por quais caminhos se chegou até o conhecimento químico atual.

Hirayama: com qual objetivo que você/que quando você deu alquimia (...)

P1: é mostrar como é que:: era... como nós chegamos hoje o que que nós éramos o que passava na MENte do/dos cientistas ou dos alquimistas na época e porque que foi se transformando transformando (...)

Segundo Porto (2010), um dos principais papéis da história da ciência no ensino é promover uma compreensão mais adequada acerca da complexidade inerente à construção do conhecimento científico. Ele defende que, para atingir tal intento, é fundamental o estudo aprofundado dos contextos nos quais certas concepções emergiram. Tomando por base tal orientação na abordagem do tema alquimia, o professor de química poderia, por exemplo, promover reflexões e discussões acerca dos prováveis motivos pelos quais a alquimia desapareceu e a 
química se desenvolveu, enfatizando como diferentes visões de mundo favorecem a disseminação e aceitação de determinadas ideias em detrimento de outras.

Entretanto, como foi visto anteriormente, apesar de ter indicado como objetivos da atividade enfatizar as transformações da ciência e o modo de pensar dos alquimistas, uma das estratégias citadas por P1 - a apresentação da história da química por parte dos alunos, "desde a alquimia até 2013" - é baseada numa perspectiva historiográfica enciclopédica que valoriza a apresentação de muitos anos da história da ciência, com ênfase em datas, nomes e "descobertas", em prejuízo da análise minuciosa e profunda das inter-relações estabelecidas entre a ciência e a sociedade de determinado período histórico.

P1 também indicou a importância de os alunos compreenderem que os cientistas não trabalham sozinhos e conhecerem as outras investigações desenvolvidas pelos ganhadores do prêmio Nobel, além daquelas pelas quais foram agraciados.

Hirayama: quando você fez aqui no primeiro ano você tinha como intuito o que assim (...)

P1: primeiro que eles conhecessem que o cientista trabalha também com outras coisas fora aquilo que ele está lá marcado... ácido de Arrhenius ( ) ele tinha esse... um cientista ele tem modelos... ele não trabalha sozinho... ele vem com outros tá? e aí... que eles conhecessem $\underline{\text { também o site }}$

A inclusão dessas questões em sala de aula pode favorecer a problematização da imagem do cientista - comumente veiculada em materiais didáticos e de divulgação científica - como um gênio que atua isoladamente na resolução das questões com as quais se depara. Apesar disso, P1 não descreveu nenhuma situação de aprendizagem que estimulasse esse tipo de discussão. A atividade mencionada por ele se restringia a solicitar aos estudantes que procurassem na internet em que ano e por qual tema determinado cientista foi laureado com o prêmio Nobel.

Embora tenha mencionado a importância de se enfatizar, mediante o trabalho com assuntos históricos, aspectos que podem contribuir para os estudantes desenvolverem visões mais adequadas sobre a ciência e o trabalho dos cientistas, P1 emitiu opiniões negativas sobre a inclusão de discussões envolvendo algumas características da construção do conhecimento científico, conforme sugerem os comentários a seguir. 
Hirayama: essa discussão de modelos atômicos ((históricos))... o que você acha... P1? você acha importante?

P1: não

Hirayama: não?

P1: não acho

Hirayama: por quê?

$P 1$ : não leva a nada... não leva a nada

Hirayama: (...) para a formacão de um:: estudante que não vai ser químico vamos supor... você acha que essa discussão é relevante?

P1: olha ele teria que... por si só buscar mais informacões... você dá...você dá o:..tapa inicial... aí fala "bom agora vocês podem ter em tal tal tal lugar porque eu tenho que tratar outras coisas mais importantes"

$---$

Hirayama: (...) se tivesse oportunidade.: de transformar (...) esse caderno do Estado... você manteria essa discussões ((históricas))?

P1: não... tiraria todas essas discussões... co/só colocaria:.... um.: fato importante.: dizendo como é que o átomo é encarado hoje... deixaria para o aluno se desenvolver... caso ele goste da disciplina

Para o docente, há outros assuntos mais importantes a serem abordados em sala de aula do que os modelos atômicos históricos. Assim, a consideração dessa questão deve ser apenas superficial para que, posteriormente, os estudantes, caso venham a desenvolver o interesse e o gosto pela disciplina de química, possam se aprofundar e aprender mais a respeito.

P1 também apresentou opiniões semelhantes em relação a outras discussões sobre a natureza do conhecimento científico, conforme evidencia o trecho abaixo.

Hirayama: (...) fala o que é teoria... né? e aponta os motivos que levaram a teoria do flogístico a ser aceita (...) os momentos de confronto e debate com outras correntes do pensamento químico (...) aponta alguns pressupostos teóricos de Lavoisier... em suas pesquisas e como e porque suas ideias foram aceitas pela comunidade científica... é:: depois ele enfatiza a contribuição de outros químicos ao trabalho de Lavoisier né? e como as ideias de Lavoisier foram se modificando lentamente com o decorrer dos estudos... é... essas ideias você acha importante trabalhar com os estudantes?

P1: (...) no:: ensino médio do Estado não acho interessante... no no ensino técnico (...) nós não estamos querendo que o técnico... se::ja um teórico... estamos querendo que o técnico seja TÉcnico mesmo em trabalhar... então estamos fugindo... mas a gente deixa em aberto para os alunos do técnico trabalharem... no Estado eu não estou trabalhando isso... de jeito nenhum

$---$

Hirayama: é... na verdade aqui a ênfase é na importância dos encontros entre cientistas para discutir e divulgar os seus trabalhos

P1: não... não

Hirayama: não? você acha que ( ) isso não é importante?

P1: não não não é importante. 
Os professores $\mathrm{P} 2$ e P3, assim como P1, também mencionaram a relevância de se considerar com os estudantes alguns aspectos relacionados à vida e ao trabalho dos cientistas. P3, ao se referir à abordagem de questões históricas envolvendo a elaboração da tabela periódica por Mendeleev, apontou como importante para a compreensão do mundo as discussões acerca de como pensam, agem e interagem os cientistas em seu trabalho.

P3: (...) como é que... o ser cientista o indivíduo cientista pensa age... interage... eu acho bacana entender... que é talvez é uma necessidade de explicar o mundo né?

P2, por sua vez, defendeu que, na abordagem de certos temas, não se pode deixar de mencionar o nome dos cientistas cujas pesquisas foram importantes para o desenvolvimento de certas áreas da ciência. Ademais, apontou a importância de se considerar o contexto social no qual alguns conhecimentos científicos foram elaborados.

P2: (...) quando se fala por exemplo de.: radioatividade... não se pode deixar de falar de Marie ((Curie)) como também não se pode deixar de falar de Pierre como também não pode se deixar falar que é/era uma pessoa de uma área - - que a Marie era uma pessoa de uma área - - que ganhou dois prêmios Nobel mas de ou:.:tras... em outras áreas também... né? então assim... e.:/e outra que tipo de vida essas pessoas tinham qual era o contexto que elas viviam... então assim existem ícones que a gente não pode em hipótese alguma deixar de falar... né? (...)

A reflexão acerca de como os cientistas trabalham, das suas motivações e das interações que estabelecem com outros cientistas e com a sociedade em geral permite aos estudantes vislumbrarem a complexidade da ciência (Porto, 2010). Também contribui para a discussão acerca da criatividade e imaginação envolvidas na elaboração das leis e teorias.

Outro ponto sobre o qual a maioria dos docentes fez referência ao comentar a importância da abordagem histórica no ensino de química foi com relação ao tempo necessário para que os conhecimentos científicos sejam elaborados.

P2, P4 e P5 apontaram como um dos aspectos relevantes na abordagem dos modelos atômicos históricos a percepção acerca do trabalho e do tempo envolvidos na construção do conhecimento científico. 
$(\ldots)$

P2: eu acho assim ó... é uma construção humana... sabe? alguém pensou (...) teve um momento para parar... um momento não... vários momentos - - que não é de uma hora pra outra... né? - - para criar alguma coisa... essa construção humana ... isso eu acho mais fundamental (...) tem toda uma construção... tem todo um trabalho (...)

----

Hirayama: (...) o que seria mais interessante os alunos aprenderem desse/dessa questão aqui ((modelos históricos))?

P4: (...) para eles é importante eles verem que... não é assim... peguei pronto aqui... vou lá que nem o sanduiche está pronto vou mastigar entendeu? veio um cara aqui e falou uma coisinha... vinte anos depois veio outro (...)

$----$

Hirayama: (...) a discussão desses modelos históricos (...) qual a importância (...)?

P5: para eles terem uma ideia de/do tempo primeiro o tempo que demora (...) para um cien/tanto que um:: cientista demora para chegar numa resposta de uma pesquisa... para eles darem valor a isso

P4 também se referiu a essa questão ao mencionar quais aspectos considera importantes que os estudantes saibam a respeito do processo de elaboração da tabela periódica.

P4: (...) eles têm que entender que isso ocorre muito lentamente... não é uma coisa que é pronta né?

---

Hirayama: (...) discutir... que os cientistas interpretam criativamente os dados... essa questão da importância dos encontros dos cientistas... para divulgação?

P4: eu acho que isso é superimportante para eles verem como é que... que... a mesma coisa de sempre... é... um resultado que eles veem abre um livro e vê lá tem um trabalho de formiguinha cada um fez um pouquinho cada um contribuiu com isso

Para a docente, a ênfase na morosidade envolvida na elaboração de ideias e produtos da ciência e tecnologia, ao se incluir abordagens históricas no ensino de química, contribui para o desenvolvimento do senso crítico e da noção de trabalho em equipe. No entanto, seu principal foco é utilizar tal perspectiva para estimular os estudantes a perceberem que, para se obter algo, se leva tempo, e é necessário muito trabalho.

\begin{tabular}{l} 
Hirayama: mas você acha importante por que essa abordagem ((histórica))? \\
P4: eles têm que entender que a... a vida não é uma prateleira de supermercado que eu vou \\
lá e quero isso vou lá e pego (...) tem que aprender a ter senso crítico (...). a ver que... a \\
\hline evolução das coisas ao longo do tempo (...) eles não trabalharam ainda né? então eles não \\
\hline sabem como tudo é construído... muito devagarzinho... tijolinho por tijolinho para fazer as \\
\hline coisas... (...) quer alguma coisa a mãe dá quer alguma coisa o pai dá... não têm... não \\
\hline passaram uma dificuldade na vida não aprenderam a ter a noção de... de... muitos não têm \\
a nocão de trabalho em equipe... trabalhar junto um auxiliar o outro e aprender também que \\
as coisas são assim né? embora nem sempre isso aconteça na ciência tem muita gente que
\end{tabular} 
tem uns que adoram puxar o tapete do outro mas:: tem que cada um contribuir um pouquinho... quando você vê alguma coisa é resultado de longos e longos anos (...)

A inclusão, no ensino de ciências, de abordagens históricas com o intuito de enfatizar que o desenvolvimento científico e tecnológico resulta de um demorado processo, o qual envolve o trabalho laborioso de diversos pesquisadores - conforme apontam P2, P4 e P5 - pode promover a compreensão da ciência como construção humana, coletiva e inacabada, pois permite a discussão acerca das dificuldades encontradas na busca pela resolução dos problemas científicos e dos conflitos inerentes à produção da ciência.

Ainda de acordo com P4 e P5, a abordagem dessa questão está relacionada com a ideia de mostrar aos estudantes que, nos dias atuais, o desenvolvimento científico e tecnológico ocorre mais rapidamente do que em outras épocas.

Hirayama: e aí...o que seria importante que os alunos vissem nesses vídeos ((envolvendo abordagens históricas)) ou... o que que você trabalharia?

P4: (...) se eles virem que gastou mais de duzentos anos para chegar a... a um modelo que a gente usa hoje em dia de... de instalação elétrica como é que as coisas... são... como que é uma bateria... como é uma pilha... né? como é como evoluiu tudo muito rápido

P4: (...) às vezes vê um pouquinho ali... outro pouquinho ali... até unir os dados e tirar uma conclusão... leva tempo trabalho... e nessa naquela época muito mais do que hoje em dia devido as dificuldades de comunicação... se eles entenderem isso... já... já foi

Hirayama: (...) o que você... dá bastante ênfase? o que é importante o aluno saber assim? P5: como a tecnologia muda tudo (...) em cem anos o que acontece (...) eles ficam bem claros disso daí né? que a tendência é... agora a ciência começar a... muitas coisas são bem mais rápidas hoje do que eram antigamente... eles sabem

Hirayama: (...) por que você acha que essa questão é importante pra eles... pra você? P5: (...) para eles verem como a evolução é muito rápida

A consideração desse aspecto enfatizado pelas docentes poderia servir de base para a reflexão a respeito de como a ciência e suas relações com a sociedade e a tecnologia têm se modificado no decorrer da história e, desse modo, contribuir para o desenvolvimento de concepções mais adequadas acerca da construção do conhecimento científico e dos fatores que interferem nesse processo (Kolstø, 2008).

Embora tenham mencionado a relevância da abordagem de assuntos que potencialmente podem contribuir para a superação de visões inadequadas acerca da natureza da ciência, P4 e P5 não fizeram menção aos inúmeros fatores que influenciaram e influenciam o desenvolvimento do conhecimento científico, tampouco apontaram a importância de preparar atividades por meio das quais os 
estudantes tivessem a oportunidade de discutir os diferentes modos de se fazer pesquisa científica no decorrer da história, e como isso afeta as interações entre ciência e sociedade.

Segundo P5, a principal finalidade de se mostrar aos estudantes a celeridade com a qual a ciência e a tecnologia se desenvolvem atualmente é contribuir para que eles possam vislumbrar uma futura carreira profissional na área.

Hirayama: você acha que isso é importante para eles?

P5: ah é muito importante porque eles vão entrar no mercado de trabalho aí pelo menos eles têm que saber escolher para o... o olhar para onde é que vai... ainda falo... a área de informática tecnologia... pesquisa... isso é uma área muito boa... está sempre mudando (...)

Após apontar que sua principal maneira de trabalhar com a história da ciência é por meio da utilização de vídeos, P4 explicou que a utilização desse recurso seria importante sobretudo para os estudantes compreenderem alguns fatos envolvidos na elaboração de ideias e materiais, bem como para desenvolverem uma visão geral dos processos envolvidos na obtenção de produtos da química.

Hirayama: e aí... o que seria importante que os alunos vissem nesses vídeos (...)?

P4: por exemplo (...) como é que foi que eles fizeram a pilha? (...)

----

P4: (...) a importância da/do desenvolvimento dos remédios... da farmacologia...

Hirayama: entendi...

P4: como é que é feito (...) todas as... são mUltas etapas... até chegar a um remédio que você vai lá na farmácia e toma (...) deveria ter essas coisas em... em:: pequenas histórias (...) um remédio um alimento... purificacãa... você vê... todas as coisas que tem... material de limpeza... (...) produtos que podem ser obtidos no ar... aí entra da amônia... que o nitrogênio é tirado do ar... aí depois produtos que podem ser tirados da água do mar... aí vem os derivados do sódio e do cloro aí tem produtos de limpeza tinta explosivo... ácido nítrico... eu tento mostrar essa sequência para eles mas gostaria... esse esquema de produtos da água do mar foi feito de... com fluxograma... não muito longo... então tem uma pequena história... não precisava entrar em tantos detalhes mas eles verem a sequência é isso e isso (...)

(...)

P4: essa sequência lógica enxuta faz eles terem uma compreensão do todo e saber isso eu chego naquilo isso... vai servir para aquilo (...)

Além disso, conforme as falas a seguir sugerem, as professoras apresentaram concepções inadequadas sobre o empreendimento científico e o trabalho dos cientistas, que podem levá-las a ignorar a abordagem de aspectos relevantes associados à ciência e à tecnologia. 
P4: (...) não tinha comunicacão de um país com o outro como tem hoje então um cara lá na França fazia uma experiência o outro na Inglaterra e o outro nos Estados Unidos e não tinha troca entre eles... e demorou quase cem anos para juntar tudo e fazer uma coisa tá? (...)

P5: (...) quando eles veem lá o tempo de Dalton para Thomson... eles até... "nossa professora vai tudo isso?" eu falo assim "é... então tudo caminha lentamente porque antes de se ter a teoria precisa de fazer várias comprovacões”(...)

Para P4, o acúmulo de ideias necessário à elaboração do conhecimento científico era mais demorado no passado em função da dificuldade de comunicação existente entre os cientistas, os quais não interagiam entre si. P5, por sua vez, considerou que a morosidade envolvida na construção e aceitação de um determinado modelo ocorre devido à necessidade de haver "várias comprovações" prévias.

As noções apresentadas pelas docentes ignoram os múltiplos fatores relacionados ao desenvolvimento da ciência e tecnologia, tais como as interações entre diferentes pesquisadores, as concordâncias e divergências entre eles, o papel das hipóteses, os diferentes contextos sociais, e outras questões que evidenciem as continuidades e rupturas ocorridas na prática científica no decorrer da história.

Ademais, P4 associou cientista a um sujeito maluco e, ao mesmo tempo, abnegado, que com seu trabalho cumpre uma missão. Tais estereótipos estão relacionados com uma concepção de ciência que ignora as motivações dos cientistas ao realizar suas investigações, bem como o papel do contexto social, político e econômico na orientação da pesquisa científica.

P4: (...). o Tesla fez isso... ele bolou tudo todo o sistema de transmissão de energia... o cara não teve nenhuma recompensa... ele veio para cumprir uma missão aqui no planeta e fez isso muito bem... não não teve não não... ele veio com tanta coisa na cabeça que ele ficou doido né? ele era doido

P2 enfatizou, em diferentes momentos das entrevistas realizadas, que a abordagem histórica em sala de aula deve promover a compreensão sobre o tempo e o trabalho envolvidos na construção do conhecimento científico, com a finalidade precípua de valorizar os cientistas e suas realizações.

P2: (...) tem que ter um/um respeito por a/por a/por quem descobriu ou por quem inventou ou por quem criou algumas coisas assim (...)

----

P2: (...) acho importante porque você tem que valorizar o que cada um fez (...) acho que isso 
((modelos históricos)) inclusive humaniza também dá mais sentido à química (...) tem todo um trabalho... ninguém pára para pensar que para você criar um modelinho desse... você abre mão de muito tempo da sua vida mesmo assim para... para fazer esse estudo e tal... isso não é valorizado... né? (...)

----

Hirayama: (...) de maneira geral...essas atividades é:: envolvendo aspectos históricos... o que que você pensa dessas atividades?

P2: eu gosto (...) porque a gente tem que valorizar quem dedicou um tempo para descobrir para pensar naquilo... para criar maneiras de.: melhorar de:: de resolver um/um/um conflito um problema (...) o tempo que a gente abre (...) da nossa vida (...) da nossa:: história com os filhos com a família... não tem vida social e tal... em troca de fazer uma atividade... para servir... né? tudo bem você ganha um título... mas é uma atividade para a/a serviço de alquém em serviço de alquém ou de várias pessoas né? (...) e quando se valori/quando se conta se coloca isso na história... ( ) valoriza quem fez é dar esse devido:: cré::dito "olha o fulano abriu mão de várias horas da vida dele para... para hoje eu estar com esse conforto aqui na minha mão" (...)

Conforme sugere o trecho acima, de acordo com a docente, dar o "devido crédito aos cientistas" pelo seu trabalho é fundamental porque eles abdicaram de parte do seu tempo, de suas vidas pessoal e social para servirem a humanidade, contribuindo para resolver conflitos e problemas, assim como para proporcionar mais conforto às pessoas.

Desse modo, P2 se aproxima da concepção, expressa também por P4, do cientista como um ser abnegado, com moral elevada, que age movido apenas pela disposição de colaborar para o bem comum. Segundo a docente, o valor formativo da história da ciência residiria em sua capacidade de motivar os estudantes a seguirem o exemplo dos grandes cientistas, percebendo que qualquer pessoa pode atingir seus objetivos por meio da dedicação e perseverança.

\footnotetext{
P2: (...) eu gosto da parte histórica né?

$(\ldots)$

P2: (...) a preocupação é na formação... que qualquer pessoa se ela tiver dedicação ... se ela estudar... se ela correr atrás (...) pode conseguir (...)

P2: a parte histórica eu acho que ela tem um compromisso com a formação... ponto... assim não é só para valorizar quem já passou... né? mas eu acho que ela tem assim... aí sim eu acho que é uma motivação (...)

----

P2: (...) vou voltar de novo na Marie (...) quando você pega a/a história dela que ela sai de uma/um país... va::i para outro com uma uma outra língua e e aí come::ça a estudar e começa a se despontar e e na/naquela área e tal... existe um esforço muito grande aí... você sair dali ir para um canto... estudar e tal... existe um esforço né? e ela era o quê? era uma pessoa normal... normal assim que eu digo assim como qualquer um...né? ( ) - - tudo bem que a mente dele não era uma mente normal era uma mente/uma mente brilhante... né?... - mas assim é brilhante porque ela persistiu também ela foi atrás... né?... essas atividades históricas eu acho que elas vão ao encontro da formação... formação de cidadão
} 
No trecho acima, P2 também associou a imagem do cientista genial e brilhante, mencionada por ela anteriormente, à persistência e à constância nos estudos.

Embora a intenção de evidenciar o papel do esforço pessoal na consecução de objetivos seja louvável em função da falta de motivação atual dos alunos para o estudo das ciências, a perspectiva hagiográfica ${ }^{15}$ apresentada pela docente pode contribuir para o desenvolvimento de visões distorcidas sobre o processo de construção da ciência. De acordo com Allchin (2004), a história da ciência segundo essa concepção santifica os cientistas e os retrata como heróis, desconsiderando seus erros e motivações, bem como as ideias de outros pesquisadores na elaboração do conhecimento científico. Além disso, está relacionada com a ideia de ciência como atividade socialmente neutra, totalmente desprovida de contradições e ambiguidades.

Desse modo, ao contrário do que P2 considerou, o uso da história da ciência visando apresentar os feitos dos grandes cientistas, escolhidos como exemplos morais para os estudantes, assim como a ênfase de que o trabalho árduo pode fazer com que qualquer pessoa alcance suas metas, não contribui para a formação cidadã, visto que não estimula a reflexão e análise dos fatores externos que podem interferir nas ações humanas. Além disso, pode diminuir a capacidade dos alunos, enquanto sujeitos comuns, de se sentirem parte integrante e atuante da história. De acordo com Chaves (2012) as narrativas heroicas são

suficientemente atraentes para inspirar belos discursos, produzir desejos, mas insuficiente para mobilizar transformações. Há no interior delas um apelo para a mudança individual descolada das condições de possibilidade históricas para a mudança (p.89).

Além de P2, P4 e P5, o sujeito P3 também mencionou como um aspecto importante do estudo da história da ciência a percepção acerca do tempo necessário

\footnotetext{
${ }^{15}$ Hagiografia é uma palavra de origem grega (hagios = santo; grafia; escrita), utilizada originalmente para se referir ao "estudo crítico do culto aos santos, ou denominar os textos medievais cujo tema central é um ou mais santos e/ou seu culto" (SILVA, A. C. L. F. (Coord.). Banco de dados das hagiografias ibéricas. (Séculos XI ao XIII). Rio de Janeiro: Pem, 2009. Coleção Hagiografia e História, v. 1. Disponível em: <http://www.pem.historia.ufrj.br/arquivo/hagiografiaehistoria v2.pdf $>$. Acesso em: 5 nov. 2015). O termo também é utilizado para designar uma abordagem histórica na qual os personagens são idealizados como exemplos de perfeição.
} 
à construção do conhecimento científico. O foco do docente é evidenciar aos estudantes o caráter provisório inerente a esse processo.

P3: (...) a ciência também é viva... ela muda como a língua... só que a mudança tem um tempo maior (...) é por isso que eu acho importante... é o tempo inteiro falando isso ó "isso não é verdade"... daqui a dez anos podemos estar falando de outro jeito tá de outra forma ----

P3: (...) é um pensamento legal se você quer pensar historicamente... ciêENcia... a ciência vai evoluindo a partir das descobertas do homem que força necessariamente... a organizacão de outros modelos explicar de outro jeito porque outra descoberta diz que aquele modelo... já não... já não responde a essa situação nova (...)

Apesar disso, tal qual P2 e P4 haviam feito ao descrever suas práticas docentes, P3 apontou o conhecimento científico como resultado de um acúmulo de ideias que progressivamente vão sendo melhoradas ao longo da história.

Hirayama: e qual... o que você acha importante os alunos saberem disso (...)?

P3: abstração... abstração e entender conhecimento cientifico que é construído em cima de modelos que são ABANDONAdos na escolha de um melhor (...)

P3: (...) acho que é importante porque... eles (...) poderiam entender (...) que não é à toa que não vem do nada não é alguém que... achou por bem fazer assim... é um acúmulo... tudo isso né? é um acúmulo de ideias... não é uma pessoa... são várias pessoas

Ainda que a fala do professor esteja associada com o caráter coletivo da ciência, a noção apresentada por ele desconsidera as crises e remodelações profundas ocorridas ao longo da construção do conhecimento científico, simplificando sobremaneira esse processo (Porto, 2010). Como aponta Cachapuz e colaboradores (2005), as novas teorias científicas não são resultado de um acúmulo de informação e de novas ideias: antes, são produtos de um processo longo

que percorre caminhos sinuosos e cujas metodologias e atividades envolvem desde relações e interpretações imaginativas, de argumentações fundamentadas, de formulações criativas, de interrogações, de modelizações, passando pela recolha cuidada e intencional de informação, de elementos observáveis (ou não), porém, sempre pensados através de hipóteses criativamente formuladas (p. 75).

P3 apontou como principal finalidade da abordagem histórica dos modelos atômicos a compreensão sobre o funcionamento da ciência, um dos principais objetivos da educação científica atualmente. 
Hirayama: (...) essa discussão dos modelos históricos (...) qual sua opinião sobre ela? (...) P3: (...) ajuda a pensar como pensou-se a ciência... eu acho só isso... porque... essa ordem pode ser invertida... eu acho que... agora é legal porque você acompanha a... as descobertas cientificas que vão mudando os modelos... isso é interessante para eles entenderem até como funciona a ciência (...)

No decorrer da entrevista, o docente fez referência à importância da história da ciência na consideração de algumas características envolvidas na elaboração dos conhecimentos científicos.

Hirayama: (...) o professor discute o que é lei e se as leis são ou não semelhantes em diferentes disciplinas (...) o sentido das leis na vida cotidiana e nas ciências físicas quer dizer... a diferença né? ele apresenta duas teorias (...) pede que os alunos escolham e justifiquem uma delas... no final ele fala sobre as características da lei periódica e as diferenças das leis na química e na física... você faria esse tipo de discussão em sala de aula? você acha que é importante? (...)

P3: (...) acho legal... acho importante... importante por isso... para eles entenderem (...) o menino escreveu lá "nos dois textos de cinética fala de teoria de colisões".... está... "mas o que é uma teoria?"

----

P3: (...) acho interessante dizer porque isso é aceito e isso não (...) então por isso que eu acho importante entender... que muda... que muda alguma coisa faz com que... alguma alguma teoria... algum pensamento... modifique... tem uma ação externa sobre

No primeiro trecho acima, P3 apontou que considera relevante a discussão acerca do que são teorias; no segundo, ao responder por quais razões comenta em sala de aula acerca do "impedimento filosófico do desenvolvimento da química orgânica", se referiu à importância de evidenciar aos estudantes os motivos pelos quais determinadas teorias são aceitas e outras não. Para ele, compreender o funcionamento da ciência e as transformações pelas quais passa o conhecimento científico ao longo da história pode mostrar aos estudantes a possibilidade de eles também mudarem suas perspectivas e ideias devido à aquisição de novos conhecimentos.

Hirayama: mas seria interessante discutir com eles essa questão da... da... da ciência... que tem várias explicações diferentes... e que os cientistas modificam as explicações (...)?

P3: (...) claro que sim...

Hirayama: por que você acha?

P3: para eles entenderem que a gente muda de posição que as coisas mudam as coisas não são estáticas... muito menos a ciência... principalmente a ciência... a ciência muda...

----

Hirayama: e... na/para a formação dos estudantes... por que você acha que entender isso ((como funciona a ciência) é importante... na sua visão? 
P3: (...) aí chega uma hora que você preClsa mudar a perspectiva né? sobre aquele... sobre aquele ponto sobre aquele olhar... porque aquilo que você falava aquilo que você discursava já não:: abarca a realidade que você tem... acho que é isso... é importante por isso eu acho... para eles eu não sei se é... para o ensino... da química em si... não acho importante... acho importante para o ensino da ciência química ou da ciência em si... essa construção... dessa percepção que você tem que mudar... aí é importante até pro aprendizado... ó estou recebendo informações novas tenho que mudar... mudar a perspectiva (...)

Hirayama: (...) essas questões que você coloca... da construção da evolução? assim qual seria o foco? (...)

P3: (...) eu acho que isso ajuda na leitura de mundo entendER como as coisas... entender que se eu preciso mudar de perspectiva com relação ao que tem na sala de aula... a diferenca... as diferencas... é mudar perspectiva...

Em seu estudo acerca da importância da história da ciência na formação do cidadão, Kolstø (2008) defende que a compreensão da ciência como construção humana, sujeita a mudanças em função de novas ideias e considerações, é fundamental para o debate democrático. Segundo o autor, o fato de a ciência não lidar com verdades absolutas implica que os leigos têm o "direito de duvidar" e, assim, podem se habilitar a participar de debates envolvendo questões sócio científicas.

No que tange a essa questão, embora tenha como principal foco a valorização dos cientistas e de seus feitos (com base numa concepção acumulativa de ciência e numa imagem dos cientistas como exemplos a serem imitados), P2 também apontou que mostrar ao aluno que os modelos não são verdade absoluta pode estimulá-los a serem mais críticos.

Hirayama: (...) o que que você acha que é mais importante eles saberem (...)?

P2: porque não é uma verdade absoluta (...) eles têm que ter condições para... para pôr em dúvida mesmo para questionar sim... como é que surge uma coisa nova? quando alguém começa a ficar incomodado começa a questionar a se perguntar (...) tem que ensinar os meninos a não responder as coisas mas saber fazer boas perguntas (...) porque através de boas perguntas é que se começa a refletir... não é? (...)

A docente P5, apesar de ter mencionado que a compreensão das mudanças ocorridas na ciência e tecnologia favorece a escolha profissional dos estudantes, apontou a motivação para o estudo da química como a principal função da inclusão da história da ciência no ensino.

Hirayama: entendi... o que é mais importante? com qual o intuito... vou perguntar assim... você insere essas ((questões históricas))? 
P5: curiosidade... simplesmente curiosidade... não que eu vá cobrar do aluno...

---

Hirayama: então você acha importante para ele se inteirar?

P5: e se interessar também pelo assunto

Hirayama: entendi... você acha que isso cria um interesse neles?

P5: mUlto... que que que cria muito... porque aí eles têm como... aí vem... vem as dúvidas vem as perguntas aí eles têm o que comentar com a gente... porque se você explicar SÓ a química... eles não sabem ainda então eles não tem como argumentar algumas coisas agora quando você coloca algo que.: eles conseguem pensar sem ser só química... aí vem as discussões (...)

De acordo com Solbes e Traver (2003), uma das explicações para o pouco interesse dos alunos pelas disciplinas científicas é o conjunto de visões inadequadas que eles possuem de ciência em função do modo como esse empreendimento é descrito ou sugerido pelos professores no decorrer da educação formal. Em sua investigação, os autores concluíram que é possível aumentar a motivação dos estudantes pelo estudo da física e da química por meio da utilização de episódios históricos, os quais permitam abordar algumas características inerentes à ciência. Desse modo, a preocupação em criar o interesse dos estudantes pelos conteúdos químicos é legítima. Apesar disso, restringir a utilização da história da ciência a esse aspecto pode conduzir a docente à abordagem superficial de alguns assuntos, enfatizando nomes, fatos curiosos, datas e deixando de lado questões mais complexas que contribuem para uma compreensão mais aprofundada da ciência e do seu desenvolvimento.

Portanto, os docentes entrevistados, em alguma medida, buscam incluir em sua prática pedagógica assuntos relacionados à história da ciência, os quais podem contribuir para a superação de visões inadequadas acerca da natureza da ciência. Ademais, de modo geral, eles apontaram, dentre outros aspectos, a relevância de se considerar algumas relações entre a ciência e a sociedade no decorrer da história, o longo tempo e o trabalho árduo envolvidos na elaboração dos conhecimentos científicos, e o caráter provisório do empreendimento científico.

Por outro lado, os professores apresentaram algumas concepções equivocadas sobre o processo de elaboração do conhecimento científico, as quais podem contribuir para o desenvolvimento de visões distorcidas a respeito do empreendimento científico e do trabalho dos cientistas por parte dos estudantes. Ademais, os professores não se referiram a algumas questões importantes inerentes ao processo de construção da ciência - como os debates entre cientistas com ideias divergentes e o papel das teorias e das hipóteses no desenvolvimento das 
investigações realizadas -, tampouco mencionaram a abordagem histórica com o intuito de lançar luz sobre características específicas da química em diferentes épocas, como as relações simbióticas com a indústria e o papel da instrumentação, dos modelos e das classificações no desenvolvimento dessa ciência.

O Quadro 06, a seguir, apresenta uma síntese das concepções e práticas dos sujeitos entrevistados no que se refere à abordagem do tema desenvolvimento histórico. 


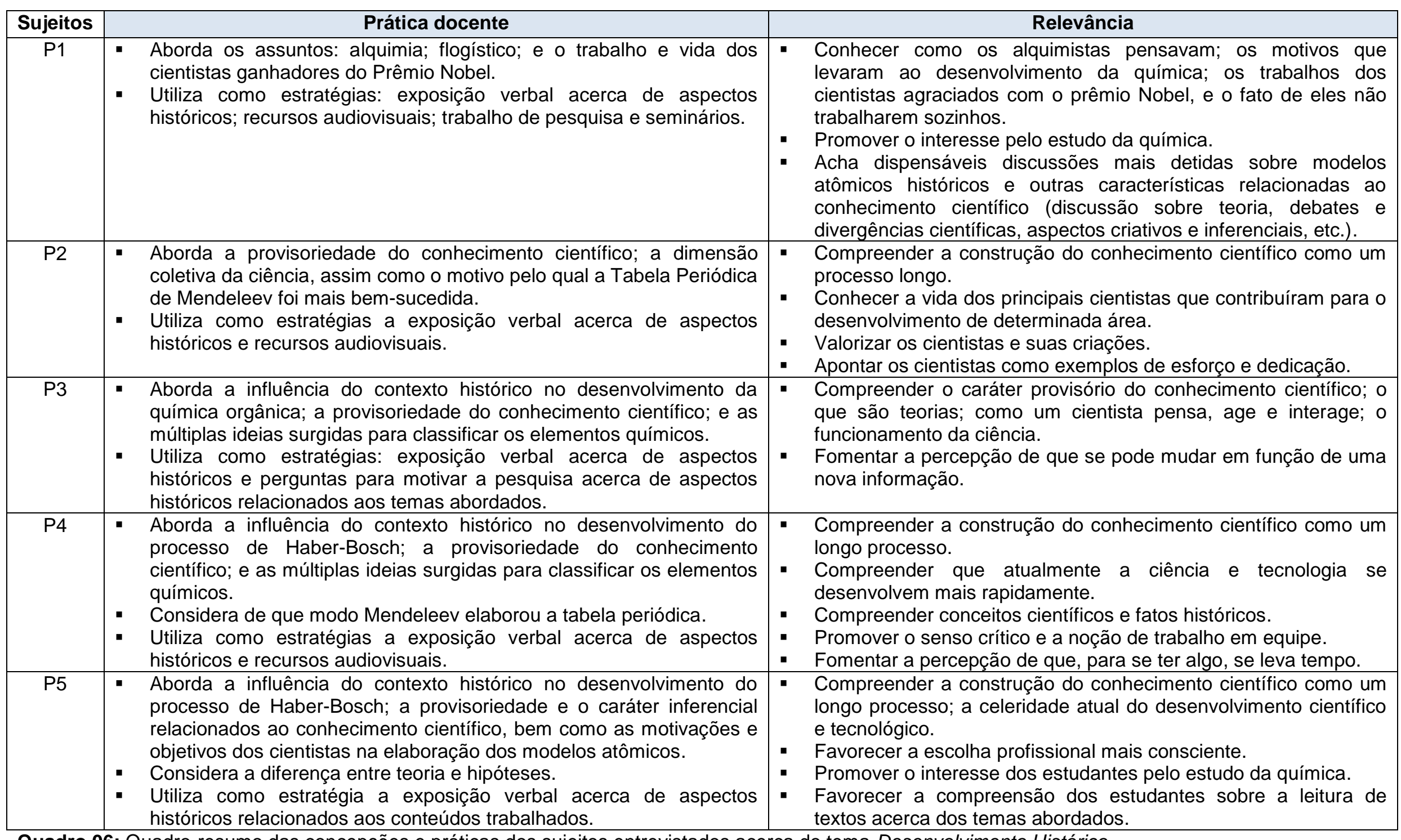

Quadro 06: Quadro-resumo das concepções e práticas dos sujeitos entrevistados acerca do tema Desenvolvimento Histórico. 


\subsubsection{Reducionismo}

\subsubsection{Prática docente}

No decorrer das entrevistas, os sujeitos investigados mencionaram a abordagem de aspectos da química que a distinguem das outras disciplinas científicas, especialmente da física, com a qual é comumente relacionada com base em uma perspectiva reducionista.

P4 e P5, ao descreverem práticas experimentais que desenvolveram nas escolas em que atuam, enfatizaram a consideração de aspectos qualitativos associados aos assuntos abordados.

P4: (...) liberação de gases (...) bicarbonato com vinagre (...) já fiz aquela experiência de cinética com pastilhinha de... de... vitamina $C$ diferença de temperatura que sai água quente água fria

(...)

P4: eles acham diferente ver cor ver coisa diferente ver uma coisa que muda o estado físico... rápida né?

Hirayama: teve alguma outra que se destaca assim?

P4: (...) a formacão de gases que é simples você pega uma garrafinha pet vai na garrafinha pet coloca um balão aí eles veem que o balão enche "olha... saiu o gás mesmo" aí você recolheu o gás e viu que o balãozinho estufa

P5: foi uma reação de decomposição da água oxigenada usando ( ) o iodeto como catalisador... eles acharam o máximo... né? que era... pasta de elefante ${ }^{16}$ né? os próprios alunos que fizeram (...) então eu pedi que eles pegassem água oxigena::da para eles verem ahn: que realmente sai gás oxigênio (...)

----

Hirayama: e como é que foi assim a a a:: os momentos anteriores e posteriores assim à prática propriamente dita?

P5: (...) mostrei a reação da água oxigenada porque muita gente confunde né? (...) aí mostrei que era o gás oxigênio que ia borbulhar e que aquela reação sempre aconteceria (...) aí eu disse que colocava catalisador e eles ainda não entendiam que ia liberar muito gás então ia fazer muita espuma (...)

P5 também ressaltou a consideração de aspectos qualitativos ao comentar como introduz para os estudantes o tema equilíbrio químico.

P5: como eu começo equilíbrio químico?... com peixe... eu trago peixe para escola... eles acham o máximo (...) pega uma aluna né? premiada para ela ir lá pôr a mão no peixe fazer carinho e o cheiro não sai... "vamos lavar com vinagre" ah:..: pronto "o que que aconteceu?"

16 "Pasta de dente de elefante" é como se denomina informalmente o experimento que envolve a produção instantânea de um volume considerável de espuma a partir da reação de decomposição da água oxigenada, utilizando-se iodeto de potássio como catalisador, na presença de detergente. 
aí... eu ponho a reação na lousa... mostro o:: né?

As considerações realizadas pelas docentes estão em consonância com estudos acerca das características específicas associadas ao conhecimento químico. Lemes (2013) ressalta que - enquanto na física os conceitos são expressos, preferencialmente, de maneira matemática, e muitas vezes não possuem uma referência intuitiva na realidade - na química os aspectos quantitativos são frequentemente associados com qualidades, como mudanças de cor e liberação de gás.

Ainda no que tange a essa questão, P5 descreveu uma atividade experimental na qual os estudantes classificaram diversos materiais em ácidos e bases.

P5: (...) eles vão trazer:: sabão... cândida (...) os grupos fazem uma única amostra para todos então eles têm que construir uma tabela... eles têm que separar os indicadores... as cores... eles fazem uma construção e no final... a minha pergunta do final é... depois de tudo que ele fez... ele vai ter que me mostrar... por exemplo... índice de naftalina... na substância... ele é básico básico tem que cor? qual a substância que você então descobriu que eram básicas? a partir de que momento que você falou que era básica? por quê? tinha alguma substância que você usou que você tem essa noção? aí geralmente eles vão falar do vinagre... porque ele sabe que o vinagre é ácido... "ah porque deu o contrário do vinagre" (...) eu não dou nada para eles... apenas eu dou indicadores e falo que vão mudar de cor no ácido básico... e aí eles vão ter que me mostrar né? tabelas... o porquê que ele separou daquele jeito (...)

Erduran (2001) aponta que o desenvolvimento do conhecimento químico está baseado fundamentalmente em modelos qualitativos e classificatórios. De acordo com a pesquisadora, conceitos químicos classificatórios, tais como ácido e sal, são ferramentas de representação que auxiliam a investigação e classificação de novas substâncias. Para Lefèvre (2012), as práticas classificatórias são fundamentais na química em função de haver inúmeros compostos diferentes, os quais podem ser identificados e ordenados de acordo com uma ou outra estrutura taxonômica. Schummer (1998), por sua vez, mostra a importância de se classificar as substâncias para prever propriedades químicas. A abordagem de ácidos e bases permite ainda discutir outro aspecto característico da química associado com a questão da classificação: os conceitos relacionais. Bernal e Daza (2010) consideram que 
assim como a identidade de uma substância é determinada por suas relações com outras substâncias e não por suas próprias qualidades em isolamento, quando são construídas classificações químicas a mesma abordagem leva a um sistema recursivo e relacional, no qual nenhuma classe pode ser definida isoladamente (p. 94).

Logo, a classificação de um material implica o estabelecimento de relações entre diferentes classes. Segundo Ribeiro (2014), visto que a definição de cada classe de substância tem como base outra classe, é necessária a construção de um ponto inicial a partir do qual o sistema relacional se desenvolve. Como exemplo, ele cita que os "ácidos foram agrupados de acordo com seu gosto azedo, as correspondentes bases e sais foram classificados de acordo com suas relações químicas com os ácidos" (p. 242).

$\mathrm{Na}$ atividade mencionada pela docente, para classificar as substâncias em ácidas ou básicas, os estudantes tiveram que estabelecer relações, tomando como ponto de partida a coloração resultante da reação dos indicadores com materiais cuja acidez ou basicidade é reconhecida no cotidiano, como, por exemplo, o vinagre. Assim, P5 envolveu os estudantes em situações de aprendizagem que, em certa medida, se aproximam da prática química autêntica, nas quais eles tiveram a oportunidade de ter contato, mesmo que superficial, com os modos de pensar e agir específicos da química, o que é importante para se compreender a atividades dos químicos e o seu desenvolvimento (Erduran, 2007).

P1, por sua vez, descreveu uma aula experimental na qual os estudantes foram instados a produzirem sabonete líquido.

\section{P1: (...) nós preparamos sabonete líquido (...)}

$(\ldots)$

P1: (...) eles tinham a receita... e eu fui explicando o que eles tinham que fazer... eles trouxeram tudo de casa... bal::de... ( ) como se fosse não um laboratório mas sim um processo uma "fabriquetinha" uma fábrica... eles produziram:: (...)

$\mathrm{Na}$ química, além de ser uma atividade central e estar relacionada mais com aspectos qualitativos, a experimentação tem como principal objetivo a análise e síntese de novos materiais. Na física, por outro lado, os experimentos são comumente utilizados para o teste de teorias (Schummer, 2004). Assim, a atividade desenvolvida por $\mathrm{P} 1$ permite ao estudante participar de atividades semelhantes às práticas químicas, e pode favorecer discussões sobre características específicas da 
química - ainda que, em suas falas, P1 não tenha fornecido indícios de que tenha feito essas discussões.

P2 e P5 apontaram ainda o trabalho com questões que permitem relacionar os níveis macroscópico e microscópico envolvidos na compreensão dos assuntos abordados.

P2: (...) não tem como você falar da ligação e mudança de estado físico sem falar das forças intermoleculares $(. .$.

(...)

P2: (...) "ó aqui dentro da garrafa de água... não tem uma molécula só... tem milhões né? então é uma molécula uma do lado da outra certo? certo... então tem um parzinho aqui mas tem outro parzinho aqui" (...) aí eu entro nas questões o que são essas forças intermoleculares (...) é a força intermolecular quando vai mudar uma substância vai mudar de estado físico né? ela não vai romper aqui... na ligação... ela vai romper aqui entre uma molécula e outra... né? por que? aí começa a discussão né? aí eles começam assim $---$

P5: (...) aqui no laboratório (...) uma das coisas que me preocupa assim... eu quero que eles saibam que existe umas ligações químicas ali e aquelas ligações vai vai gerar forças entre as moléculas que vai deixar uns serem compostos gasosos... sólidos... então eu quero que eles tenham E-sse conhecimento... então por exemplo "ah pega ali o vidro de alguma coisa" então... eles já sabem eu quero já que eles já lem::brem... que tipo de forcas... aquele modelo gerou aquela ligação que teve uma força intermolecular e tal que ele vai encontrar o produto aqui dentro... na... no estado sólido liquido... o que for... volátil (...)

P5: ah eles acham o máximo por exemplo a propriedade da água... né? que é a do lagarto que eu falo que ele vai pisando... "ah::.: professora" ( ) aí fala que no álcool é diferen::te... aí eles aí eles começam a pensar né? na atração das molé::Culas... porque que um... certa substância dá para prever que ela pode estar ser volá::til a outra não devido as forças (...) devido a ponte de hidrogênio (...)

(...)

P5: (...) aí já dou junto com compostos orgânicos... de cadeias ramificadas e pontos de ebulição... já vai com ponto de ebulição de cadeias ramificadas (...)

(...)

P5: (...) eu peço sempre assim "justifi::que a diferença de um para o outro... porque que um tem a temperatura/por que você acha que a temperatura de ebulição de um é mais alta do que a outra?" dou vá:::rias... aí eles vão comparando eles vão fazendo por comparação... "porque naquele composto tá ocorrendo uma forca tal e devido a isso" (...)

As docentes P2 e P5 mencionaram que buscam incentivar os estudantes a explicar as propriedades dos materiais com base nos modelos de ligação entre os átomos e de interação entre as moléculas. Desse modo, fizeram referência a uma abordagem tipicamente química, a qual dá ênfase em como as partículas estão organizadas e interagem entre si - diferente da física, que trabalha com os objetos isolados (Schummer, 1998; Lemes, 2013). 


\subsubsection{Relevância}

Além de práticas por meio das quais alguns aspectos associados ao conhecimento químico podem ser trabalhados, os sujeitos entrevistados mencionaram a importância de se considerar com os estudantes questões que remetem a características específicas da química.

Os docentes P1, P2 e P5, ao comentarem acerca de quais pontos são importantes na abordagem do tema equilíbrio químico, se referiram mais aos aspectos qualitativos envolvidos do que aos quantitativos.

\footnotetext{
Hirayama: (...) qual que seria (...) as principais questões que você é:: acha importante que eles tenham no final que eles aprendam o que sobre equilíbrio químico (...)?

P1: o.: deslocamento de equilíbrio... o deslocamento... uma variação de... de concentração... variação de $\mathrm{pH}$... isso é importante... se eles conseguirem enxergar isso que a reação pode voltar como variação de... de concentração isso é importante

(...)

P1: a:: você pode trabalhar com:: até:: (...) com suco de repolho roxo dá para traba/você enxergar variando o $\mathrm{pH} . .$. aí a mudança de cor... com a mudança de cor é mais fácil eles enxergarem

Hirayama: você prefere trabalhar em termos de de:: de aspectos:: qualitativos ou de de con::tas de:.... constantes de equilíbrio o que que você?

P1: qualitativo... qua-li-ta-ti-vo

Hirayama: o mais importante pra ele assim... éh:: para você no caso né? ele compreender... éh:: a parte qualitativa ou quantitativa? (...)

P5: a qualitativa...

Hirayama: por que você acha?

P5: (...) a quantitativa ele vai aprender a fazer lá cálculo... matemática... calcular constante fazer formulinha tanãnã... entendeu? agora na qualitativa ele vai aprender os:.... a... a situar as coisas (...) eu quero que ele tenha... que ele saiba... que aquilo ia ter lógica...

$-1$

P5: eu quero que ele entenda o que é um equilíbrio químico e que aquele equilíbrio pode ser deslocado

Hirayama: (...) o aluno é mais importante nesse ponto... ele..... aprender a parte quantitativa do equilíbrio (...) ou seria mais importante ele entender os conceitos envolvendo o equilíbrio?

P2: eu acho... eu acho que os conceitos

Hirayama: uhum

P2: (...) se ele entende o conceito se ele entende o o o comportamento da substância dentro de determinada situação... sinceramente o cálculo ali é...é:: de interesse maior para quem? (...) quem é o químico quem... trabalha com aquilo ou quem vai fazer uma um vestibular de uma disciplina de uma/para uma área... que:: precise de fato bastante química... né?... do contrário acho que se ele entender o conceito... para mim é melhor
} 
Embora o ensino de química também envolva a realização e compreensão de cálculos e contas, Talanquer (2013) aponta que é importante engajar os alunos nos modos específicos de ver, analisar e transformar o mundo que são essenciais para os químicos. Desse modo, o foco nos aspectos conceituais contribui para que os docentes ensinem química de um modo mais autêntico.

Apesar disso, os sujeitos entrevistados não apontaram a importância de considerar tais aspectos em função da natureza específica da química. $O$ destaque dado por P1 aos parâmetros qualitativos está associado à dificuldade dos estudantes em realizar cálculos e a sua preferência pela abordagem dos aspectos fenomenológicos em detrimento da consideração de questões teóricas.

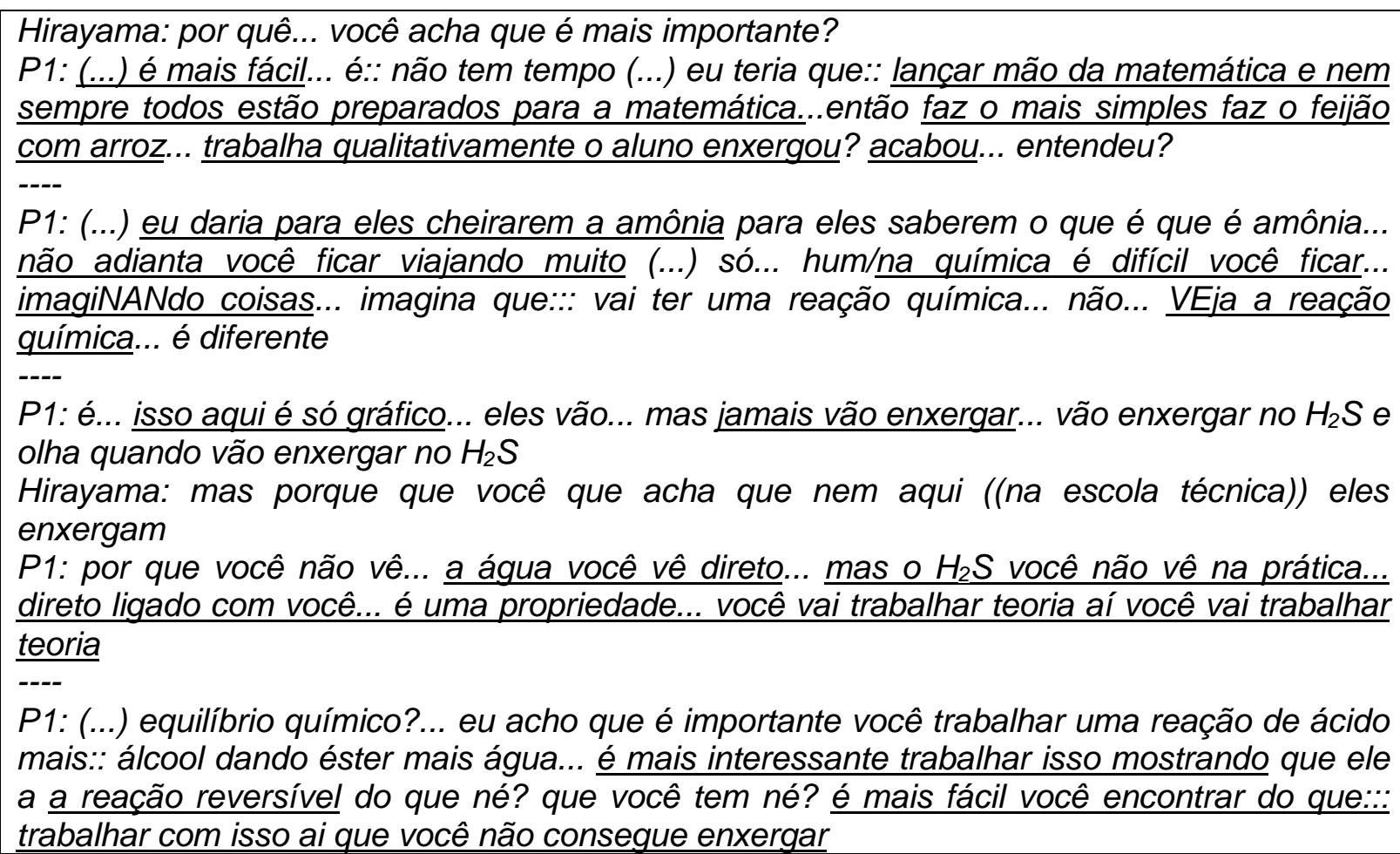

De acordo com alguns pesquisadores, em comparação com a física, a química apresenta um pronunciado caráter experimental (Kovac, 2002). Assim, valorizar as atividades experimentais no ensino de química, como faz P1, favorece a preparação de situações de aprendizagem nas quais os estudantes tenham a oportunidade de se aproximar do modo de pensar e agir dos químicos, bem como pode contribuir para a promoção de discussões sobre as características peculiares da química. Entretanto, o desprezo pela abordagem dos aspectos teóricos associados aos fenômenos estudados pode levar o docente a não incluir em sua 
prática outros aspectos importantes da química, como os modelos, a linguagem e os níveis de representação. Como aponta Lemes (2013), as evidências experimentais não revelam, em um primeiro momento, nada acerca do comportamento microscópico dos fenômenos e materiais estudados. Desse modo, desconsiderar as relações entre os níveis macro e microscópico no ensino de química pode prejudicar a compreensão dos estudantes sobre os assuntos abordados.

P2, embora tenha mencionado os aspectos quantitativos como interessantes somente para os estudantes que atuarão diretamente na área, apontou, de modo explícito, que, embora importantes, cálculos e quantificações não são a "essência da química".

P2: (...) química não é só fazer conta... não é cálculo só... tudo bem precisa fazer precisa entender precisa entender proporções éh... calcular a massa calcular isso tal... precisa mas não é o cerne não é mais importante

(...)

P2: em qualquer área da química...em qualquer conteúdo em qualquer conteúdo seja trabalhando na química orgânica na analítica na inorgânica... qualquer área assim... para mim o cálculo é importante... ponto... mas não é o não é a essência da/da/da química

Segundo P5, a consideração dos aspectos qualitativos, além de favorecer a compreensão dos conceitos envolvidos, contribui para aumentar a curiosidade e o gosto dos estudantes pela química e o seu estudo.

P5: (...) aí nós fizemos com o exemplo do peixe que é o mais simples todo mundo sabe que tem um cheiro horrível... só que eu queria que ele tivesse noção que aquilo iria existir... porquê que ia acontecer aquilo... aí eu mostrei a reação mostrei do vinagre... aí eles "ah professora... realmente"... eles começaram a ter ideia... uma ideia melhor sobre o que estava acontecendo

P5: (...) aí nós fizemos a reação química e quando eles colocaram o iodeto e aí foi RÁpido... e aí eles gostaram muito de ter visto aquilo e eu acho que entendeu muito bem o que é que era um catalisador

$---$

P5: (...) até aí nada agora na hora da reação aí foi "nossa:: que legal professora agora eu estou vendo como foi rápido por isso que sai esse monte de espuma"... então quer dizer... isso daí para perceber que quando eles estão vendo acontecer... éh... a curiosidade a vontade de ver é mai/ é outra...

Para P3, a química envolve ambos os aspectos: qualitativo e quantitativo. Entretanto, assim como P1, ele aponta que é difícil abordar a parte matemática relacionada ao tema equilíbrio químico, em virtude da dificuldade dos estudantes na realização de cálculos e no desenvolvimento do raciocínio proporcional. 
P3: (...) tem dois aspectos em qualquer ponto em química... o qualitativo e o quantitativo... você esbarra no quantitativo na dificuldade de matemática que eles têm... eles não sabem somar fração... não sabem... pode dizer aí é verdade a gente prova... não são todos... não têm raciocínio proporcional trabalhado que é o que mais a gente precisa (...)

De acordo com Talanquer (2013), a concepção reducionista, segundo a qual os conhecimentos químicos poderiam ser deduzidos das leis e princípios da física, favorece o entendimento de que somente as teorias e modelos químicos expressos em termos físico-matemáticos são mais corretos e científicos. Tal visão, segundo ele, pode influenciar o ensino de ciências que passaria a valorizar excessivamente os modelos quantitativos e algoritmos - mais característicos da física.

Dentre os docentes entrevistados, P4 foi a que mais citou a importância dos aspectos quantitativos associados aos temas discutidos e a preocupação com a falta de conhecimentos básicos dos estudantes em matemática. Para ela, o treinamento em matemática desde a tenra infância é fundamental no desenvolvimento do raciocínio lógico e da capacidade de abstração e análise.

P4: (...) por exemplo carbono e hidrogênio queima do etanol (...) para você fazer um cálculo assim (comum) para eles... eles não conseguem entender já fica mais abstrato para eles... eles têm uma defasagem de matemática muito grande (...)

----

P4: (...) faz uma diferença enorme se tivesse uma aula a mais no terceiro ano para você... seria o momento de... daqueles do::eles já têm um pouquinho mais de maturidade mais de conhecimento... já melhoraram um pouquinho a matemática... mas você... aí sim você pode pegar eles para fazer experiência com número decimais... a vida real não é número inteiro né? você faz um exercício de conservação da matéria que tem lá um número... "ai um número quebrado"... você não vai pra frente

----

P4: (...) o pessoal é muito ruim com o desenvolvimento de... de de análise de tirar conclusão entendeu? eu acho que tinha que ter um treinamento mais intenso tinha que ter... a matemática tinha que ser... tem que ter uma maior cobrança porque você vai treinando de resolver uma equação e chegar no resultado e tira uma conclusão... aí você vai aprendendo uma sequência lógica de pensar que você pode aplicar em qualquer outra coisa

(...)

Hirayama: qual seria a importância da matemática assim pra química?

P4: eles tinham que aprender desde pequenininho a... a ter pensamento lógico... não é esperar chegar na... no ensino médio... tem a matemática... não adianta... eles não sabem tabuada (...) você manda somar $39+1$ eles dá 49

----

P4: (...) começa a falar... da importância do tamanho da partícula... os fatores que influenciam velocidade de reação... aí eu passo exercício de outro livro... fazer cálculo com... (...)

P4: (...) variação - - de outro livro daqui não tem - - velocidade varia... ( ) fazer gráfico de variação da massa com o tempo... variação da massa com o tempo tem que fazer cálculo de velocidade porque sempre cai em:: ( ) 


\begin{abstract}
(...)
Hirayama: então o que você pega em outro livro seria para colocar aqui?

P4: cálculo de variação da velocidade (...) de reação aqui não tem nenhum exercício sobre isso

Hirayama: para calcular a velocidade da reação é isso?

P4: é... e construir o gráfico... fazer... calcular velocidade... com o tempo... variação da massa com o tempo (...)

Hirayama: (...) o que que você acha mais importante os alunos saberem? éh:.... no equilíbrio tem muito... as questões qualitativas né?... as explicacões os conceitos... e também a parte matemática que é a parte quantitativa... o que você acha que é mais importante? (...)

P4: tem que saber um pouquinho de cada um (...) interpretar gráfico... todas as maneiras que puder ensinar um pouquinho de:: de:: conhecimento lógico eu passo (...) nem sempre $o$ professor de matemática fica fazendo isso com eles e depois quando eles vão fazer os: os vestibular da vida e aí não sabe (...) sempre passo construção de gráfico... interpretação de tabela... tem que saber olhar um gráfico e saber está aumentando tá diminuindo... está estacionado... tem que saber

(...)

Hirayama: (...) nessa parte de equilíbrio da apostila você acha que faltaria o que (...)?

P4: exercícios exercícios com velocidade de reação interpretação de gráfico... interpretação de tabela... não tem nenhum exercício para eles construir ou interpretar gráfico... de cinética... saber distinguir se uma reação é exotérmica endotérmica... energia de ativação... energia da reação
\end{abstract}

Apesar de mencionar que os estudantes devem compreender os aspectos qualitativos e quantitativos relacionados ao tema equilíbrio, P4 enfatizou em sua resposta apenas a interpretação de gráficos e tabelas, assim como a realização de cálculos. Para ela, a abordagem dessas questões é importante, pois prepara os alunos para os exames vestibulares.

Embora tenha dado destaque aos cálculos e aspectos quantitativos associados aos conhecimentos químicos, P4 apontou a importância de os estudantes compreenderem as propriedades da água a partir das interações entre as moléculas de água.

Hirayama: entendi... idealmente o que seria importante que eles soubessem?

P4: éh... que eles procurassem saber tudo né? (...) a diferença da água... o arranjo da/da/das pontes de hidrogênio em estado líquido o estado sólido... você até passa na lousa mostra eles olham assim... vai ter já vai ter um grupo na feira de ciências que vai fazer experiência com:: tensão superficial umas coisas assim para ver se eles relacio::nam (...) você queria que a explicação fosse em vários níveis para ele entender a nível microscópico né? seria o ideal né? mas eu não sei se chega lá não

P2 e P3 também apontaram a importância desse aspecto no ensino de química.

P2: (...) entraria nas propriedades físico-químicas dela ((da água)) mesmo... então... eu 
entraria por exemplo em ponto de fusão ponto de ebulição a ponte de hidrogênio né? ou:: ligação de hidrogênio né? porque que a molécula tem aquela forma... porque que/de onde surgiu esse tal de cento e quatro vírgula alguma coisa graus e tal (...)

----

P2: (...) né? que quando uma substância por exemplo muda de um estado Fĺ-si-co não há uma mudança intramolecular e sim intermolecular... né? então isso ele não pode sair é é sem sem saber né?

(...)

Hirayama: (...) porque que isso é importante para o aluno?

P2: porque por exemplo assim ó... porque que uma substância... passa de um estado físico para o outro (...) por exemplo para um professor de geografia... ele vai falar só dos estados físicos lá do que interfere nisso ou naquilo... mas não vai estudar a matéria em si... a nossa praia não... a gente tem que dizer "olha isso está é é essa matéria está passando desse estado para outro porque as moléculas estão" e aí você entra com todo teu... todo teu know how né?

$---$

Hirayama: (...) nos cadernos do Estado existem essas atividades envolvendo as propriedades peculiares da água né?

P3: sim...

(...)

Hirayama: o objetivo seria ideal assim... qual?

P3: aqui nesse caso as ligações entre as moléculas (...) que/na verdade que gera... que já foi discutido questão de propriedades... eles têm que entender... e eu digo sempre... não é o carro na frentes dos bois... as coisas são como são... a ciência apenas tenta expliCAR:: a situação... então saber da propriedade material é fundamental para reconhecer o mundo $E$ ajudar na... no entendimento cientifico

Como visto anteriormente, alguns conceitos químicos não podem ser compreendidos com base numa abordagem física que comumente trabalha com seus objetos de estudo de modo isolado. Na química, a compreensão do mundo material e das reações devem levar em conta os arranjos das moléculas e o modo como elas interagem entre si (Schummer, 1998; Lemes, 2013). Desse modo, assim como apontam os docentes, é importante incentivar os alunos a estabelecerem relações apropriadas entre os níveis macroscópicos e microscópicos associados aos fenômenos estudados.

Outro aspecto comentado pelos docentes no decorrer das entrevistas, relacionado ao reducionismo, é com respeito a abordagem das diferenças entre as leis na física e na química. Para $\mathrm{P} 1$, a reflexão sobre essa questão não é interessante devido às dificuldades dos estudantes.

Hirayama: (...) o professor discute o que é lei... e se as leis são ou não semelhantes em diferentes disciplinas né? (...) essas discussões... elas são importantes (...)?

$P 1$ : se elas são pertinentes né? não eu acho que não

Hirayama: nem interessantes... para os alunos?

P1: por enquanto não... eu deixaria mais para frente... onde... ele... através de uma evolução chegasse nisso aí... é por enquanto... nós estamos trabalhando em:: fazer com que 0 
aluno... consiga interpretar o que ele está lendo (...)

P5, por sua vez, considerou que os estudantes por si sós percebem as diferenças entre os conceitos físicos e químicos, não sendo necessário um trabalho específico a respeito desse assunto.

Hirayama: se as leis que eu tenho na física e na química se elas são da mesma natureza se elas são iguais né?

P5: é... elas não são...

Hirayama: você acha importante os alunos saberem isso?

P5: ah eu acho que eles descobrem por si só sem precisar de falar...

Hirayama: por aqui tem um exemplo da lei da gravitação e da lei... de... de... de periódico né?

P5: então por isso que eu estou te falando... éh... então eles descobrem isso sem você nem precisa falar ué (...)

P2 e P4 apontaram que essa questão já é trabalhada com os estudantes desde o primeiro ano do ensino médio.

Hirayama: (...) o que que você acha dessa atividade né?

P2: (...) eu gosto (...) o fato deles escolherem uma das duas aqui teoria um ou teoria dois é força o debate força é/força a conversa (...) então isso isso gera uma discussão isso é bom... isso é bom

Hirayama: e as discussões em si (...) você acha que isso é importante para os para os estudantes é interessante você faria?

P2: em termos de conteúdo eu acho que sim... mas eu ainda gosto mais da discussão do que:: se é importante ou não

(...)

P2: (...) porque quando eu chego lá e vou falar assim olha fazer a diferença entre a::...a física e a química...né? essa diferença de fíllei física:: e.: le::i química acho que isso a gente já vem fazendo desde o primeiro a::no com muita tranquilidade... né? por isso que eu acho que seria... um pouco... batido aqui (...)

(...)

P2: (...) quando os meninos estão lá no nono ano você fala assim ó... "aqui vocês têm professor de ciênCIAS:: plural né? só que quando você vai para o ensino médio... você vai ter três professores para ciências né? um para física química e biologia qual a diferença uma da outra o que que todo mundo vai estudar a mesma coisa só que em aspectos diferentes... né? por exemplo a biologia vai estudar a:: vamos supor o os seres vivos... mas química também estuda os seres vivos só que a preocupação dele é o quê né? é a matéria... né? e a física? os movimentos daquela da/daquela:: matéria" enfim é::outros fatores também que eu não vou entrar em todos assim (...)

----

Hirayama: você acha interessante essa discussão sobre as diferenças das leis na química e na física? éh... o que é característico da química? o que é característico da física?

P4: acho que sim... isso é uma das coisas que... quando:: quando está comecAN::do as primeiras aulas de química física do ensino médico você costuma fazer... a química estuda isso isso a física estuda isso e isso (...) o início de primeiro ano falar isso eles não aprenderam ainda... não sabe... não tem noção do que seja... tem que ser um pouco mais adiante 
$(\ldots)$

P4: pode-se tentar... em geral você faz isso no começo do primeiro ano né? as primeiras aulas para eles... quando eles veem ciências eles não costumam prestar muita atenção o que é física o que é química... aí depois quando vai para o primeiro ano já... já pode-se tentar sim...

Para P2, a atividade sugerida é relevante apenas pelo seu potencial de gerar uma discussão entre os estudantes, enquanto P4 considera interessante apontar as diferenças entre a física e a química ao final do primeiro ano do ensino médio.

Desse modo, as docentes P2, P4 e P5 parecem focar nas diferenças entre a física e a química enquanto disciplinas escolares, desconsiderando as peculiaridades epistemológicas e históricas da química como disciplina científica.

Alguns professores entrevistados emitiram também opiniões negativas sobre a inclusão, no ensino de química, de reflexões filosóficas envolvendo o reducionismo no estudo da química da água. P1 considerou interessante a ideia de discutir com os estudantes acerca da substância água. Contudo, ao apontar quais modificações faria na atividade apresentada, o docente destacou apenas os aspectos fenomenológicos envolvidos, excluindo as discussões filosóficas que, de acordo com Erduran e Scerri (2002), poderiam favorecer a percepção dos estudantes sobre as características específicas da química.

\footnotetext{
Hirayama: (...) o estudo das propriedades re/peculiares da água (...) o que que você acha dessa atividade $P 1(. .$.$) ?$

(...)

P1: eu acho interessante (...) tem uma coisa que foi esquilesquecido aí e o:: a fusão... até a ebulição não foi nem colocado vapor de áqua... só foi colocado líquido:: e:: o sólido... poderia ser trabalhado inclusive o o a água no estado gasoso (...)

Hirayama: (...) questão de uma molécula pode ferver... se $\mathrm{H}_{2} \mathrm{O}$ é a mesma coisa que a água ou se a água é igual a $\mathrm{H}_{2} \mathrm{O}$... a questão do gelo... você acha importante (...)?

P1: é::: no lugar da molécula eu colocaria mol né? mol molécula é muito::: né?::: irrelevante aí... você falar "molécula de água" o que que é uma molécula de água eu colocaria já a água... ou tiraria né? poderia o/a água ferver a cem graus?

Hirayama: entendi

P1: poderia a água ferver a cem graus não... tira molécula mol... para ele entender a questão da água...né? colocaria sim sem dúvida... é interessante

Hirayama: você fala pra entender a questão da água... que questão é:: seria?

P1: ó o:: geral a água... tirando o:: os periféricos né?... molécula é um periférico então a água ele entende a água se você falar molécula ele já vai ficar em::tre "o que que é molécula da água... uma molécula... uma molécula é só $\mathrm{H}_{2} \mathrm{O}$ ? se a gente for falar nós dois como químicos falar "pô... mas você vai ferver uma molécula de água?" quanto você tem dezoito gramas de água são seiscentos e dois sextilhões de moléculas.... então fica meio... paradoxal... então é melhor você falar "pode a água ferver a cem graus?" ficaria melhor Hirayama: e aí que discussão você faria em cima dessa/dessa questão?

P1: ah:: ficaria entre... o:: pressão atmosférica e temperatura... trabalharia mais nesse aspecto
} 
Hirayama: (...) desse trabalho é isso que você modificaria (...)?

P1: (...) tiraria a:: molécula colocaria só água para o aluno entender melhor... e::.: colocaria pressão atmosférica e tem um trabalho... sobre pressão atmosférica e temperatura (...)

Para P2, as questões propostas na atividade não são interessantes e não têm a capacidade de estimular a discussão entre os estudantes.

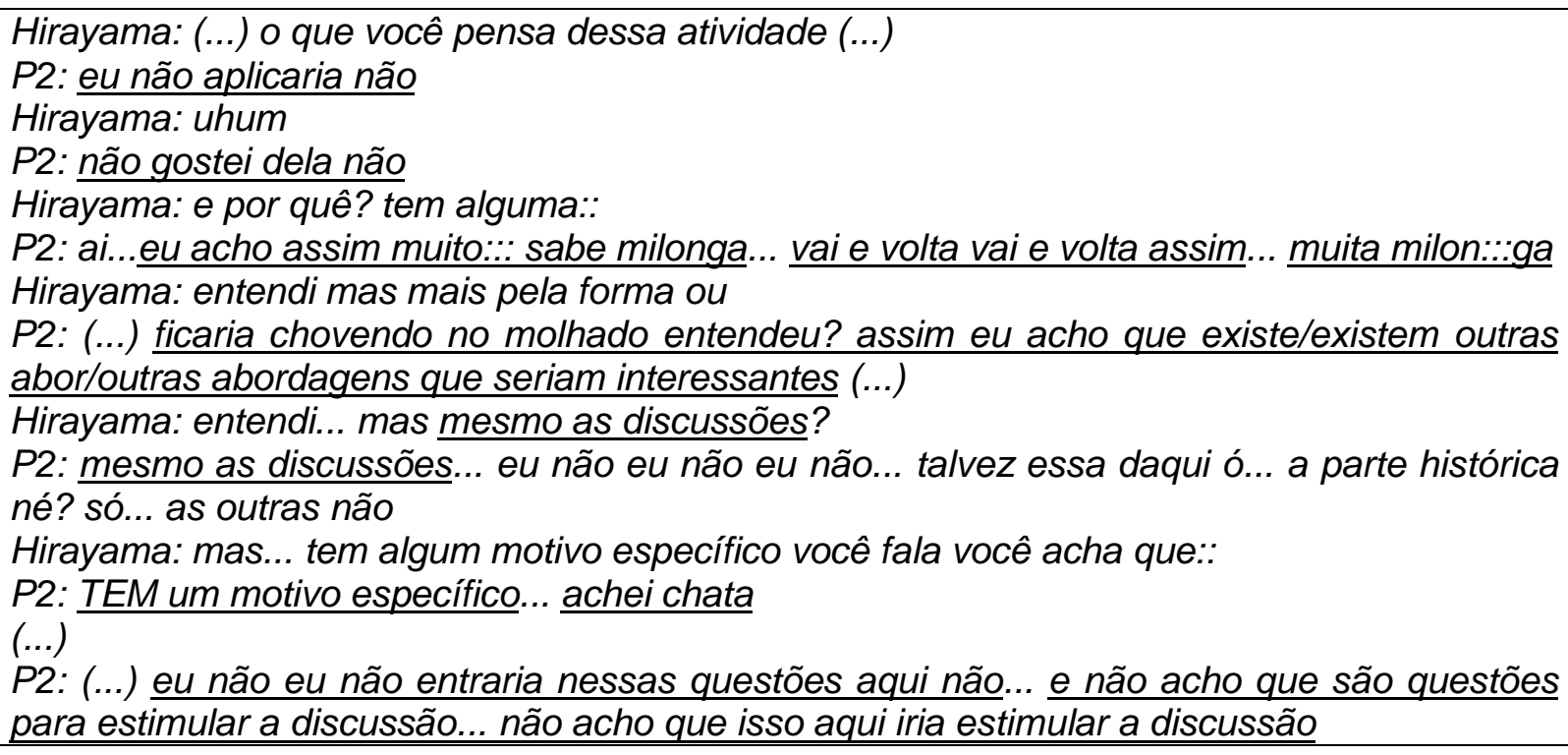

P3, por sua vez, aponta a dificuldade de abstração dos estudantes como um empecilho para a realização da atividade.

P3: (...) tratar esse tema é pensar que eles conseguem abstrair... né? (...) você põe uma equação química... sei lá... você põe $\mathrm{H}_{2} \mathrm{O}$ (I) líquido seta... eu peço para ler... é $\mathrm{H}_{2} \mathrm{O}$ (v)... aí eles pulam a seta eles não leem... $\mathrm{H}_{2} \mathrm{O}$... "mas o que é isso aqui? como você lê isso aqui? isso não quer dizer nada?" então até isso... na leitura... é por isso que eles não conseguem ir a esse lugar eu acho... que eles não conseguem abstração da... ou seja... símbolos signos... para eles é uma dificuldade... eles não têm esse domínio... eu acho... primeiro por falta de abstração (...)

No entanto, ele considera a discussão sobre o reducionismo no estudo da química da água importante para que os estudantes compreendam o papel das representações na química.

P3: (...) eu não consigo ter um menino do terceiro falando CaO ((zero)) porra... "como é que você lê zero numa representação? zero não existe"... aí você fica claro que ele não entende NADA da representação (...)

Hirayama: esse seria o principal objetivo para você assim? dessa discussão?

P3: sim... porque se ele lê... $\mathrm{H}_{2} \mathrm{O}$ pode ser $\mathrm{H}_{2} \mathrm{O}$ ((zero)) então ele não entende que isso está no lugar de um material é uma linguagem específica de uma ciência que tenta trazer essa 
discussão... ele não entende nada... NADA... para mim é muito claro...

Hirayama: entendi...

P3: nada... não entende nada dessa representação... então assim... para mim é super válida essa discussão aqui... né?

A princípio, P5 mencionou que não realizaria as discussões sugeridas em sala de aula, pois não seria possível associá-las com alguma prática experimental.

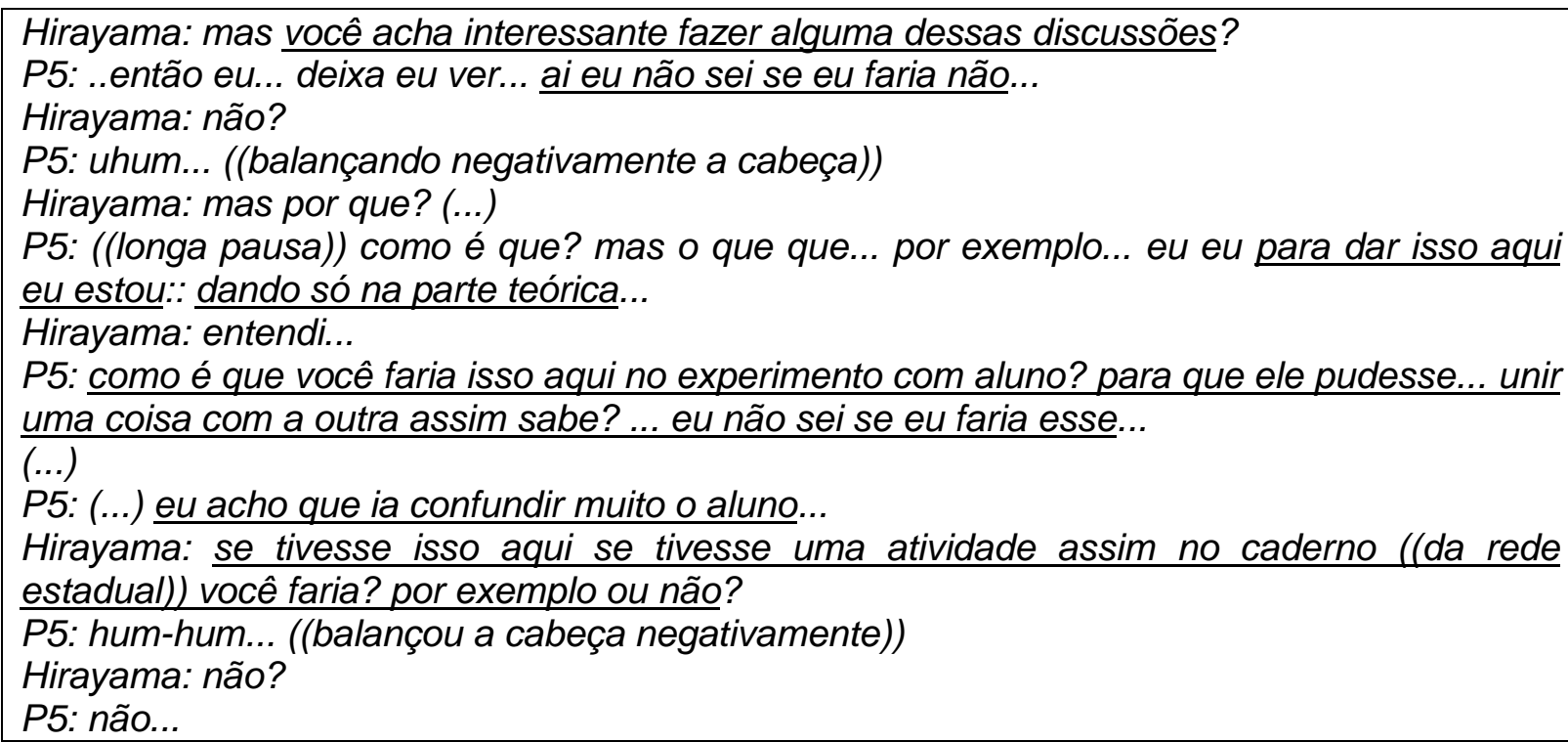

Posteriormente, porém, a docente comentou que a abordagem das discussões filosóficas envolvendo o reducionismo seria importante para que os estudantes compreendessem as propriedades físicas da água. No entanto, para ela, a discussão deveria acontecer junto com a abordagem de massa molar, número de Avogadro e mol.

P5: (...) eu não sei como é que eu faria o aluno entender essa parte precisaria de ter um exemplo de alguém mostrando para que depois eu possa... na hora que eu for entrar com mol molécula volume ele conseguir entender (...)

Hirayama: entendi... você acha que tem que ter mais com essa essa parte assim?

P5: olha para você ter ideia no primeiro ano eu tento falar com eles o que é molécula (...) aí quando eu vou explicar (...) o que é o número de Avogadro os/como chega na massa molar... Aí é que eles começam a entenDER da onde que vêm aqueles números das tabelas... porquê aquilo... entendeu? (...) não consigo fazer isso aqui uma discussão separada...

Hirayama: (...) seria difícil eles entenderem é isso?

P5: é (...) ela teria que estar junto com o conteúdo... junto com alguma coisa (...)

Hirayama: (...) mas você acha que seria seria importante para formação dos estudantes alguma algumas dessas questões?

P5: ah lógico né? ( ) para saber que... para saber temperatura de ebulição:: fusão... 
P4 considerou interessante a abordagem de algumas discussões envolvendo o reducionismo no estudo da química da água e, até mesmo, comentou de que modo a atividade sugerida poderia ser realizada na escola onde trabalha.

P4: eu nunca pensei nisso é interessante... esse dá para fazer com o primeiro ano... nunca fiz isso "gelo é igual a água" né?... você tem que escrever lá... às vezes eu escrevo "água sólida" e eles já ficam pensando "o que que é isso mesmo? gelo é água sólida"(...)

Hirayama: você acha interessante trabalhar com isso?

P4: é... você tem que ( ) esse aí eu nunca pensei dá para fazer... você pode fazer um desenhinho né?... mandar eles refletir sobre isso...

Hirayama: aqui por exemplo o professor escreve na lousa "água é $\mathrm{H}_{2} \mathrm{O}$ " e depois realiza uma discussão "você concorda com essa afirmação?" você acha que o primeiro ano...

P4: esse dá para fazer até com oitava série... é uma coisa que eles veem no dia a dia... capaz de sair... essa aí é interessante... pedir para eles... podia até ensinar densidade junto de uma vez... você fica lá... põe o gelo na água ele boia põe o gelo no/no álcool ele flutua... ele fica assim "hum... por que"?

De maneira geral, os sujeitos entrevistados teceram considerações que remetem a características específicas da química, as quais a distinguem das outras disciplinas científicas. A maioria enfatizou a relevância de se abordar os parâmetros qualitativos, associados aos conhecimentos e ao desenvolvimento da química, assim como apontou a realização de atividades - envolvendo a classificação, a produção de materiais e o estabelecimento de relações entre os níveis macro e microscópicos - que podem favorecer a abordagem de questões específicas acerca da química.

Apesar disso, nenhum professor justificou a importância de se trabalhar as questões mencionadas em função da natureza específica do conhecimento químico. Mesmo quando questionados sobre uma atividade que propõe a discussão sobre as diferenças entre as leis na física e na química, os entrevistados não se referiram à relevância da preparação de situações didáticas por meio das quais os estudantes possam compreender a natureza da química.

O Quadro 07, a seguir, apresenta uma síntese das concepções e práticas dos sujeitos entrevistados no que se refere à abordagem do tema reducionismo. 


\begin{tabular}{|c|c|c|}
\hline Sujeitos & Prática docente & Relevância \\
\hline P1 & $\begin{array}{l}\text { - Atividade experimental envolvendo a } \\
\text { produção de substâncias. }\end{array}$ & $\begin{array}{l}\text { - Aspectos qualitativos na abordagem do equilíbrio químico são mais relevantes do que os } \\
\text { quantitativos. } \\
\text { - Desinteresse pela abordagem das diferenças entre as leis na física e na química. } \\
\text { - Opiniões negativas sobre a inclusão no ensino de química de reflexões filosóficas } \\
\text { envolvendo o tema reducionismo no estudo da química da água. }\end{array}$ \\
\hline P2 & $\begin{array}{l}\text { - Relaciona a organização e interação das } \\
\text { partículas com as propriedades dos } \\
\text { materiais. }\end{array}$ & $\begin{array}{l}\text { - Aspectos qualitativos na abordagem do equilíbrio químico são mais relevantes do que os } \\
\text { - } \quad \text { Impantitativos (aspectos quantitativos não são o cerne da química). } \\
\text { química da água para a compreensão de suas propriedades. } \\
\text { - Opiniões negativas sobre a inclusão, no ensino de química, de reflexões filosóficas } \\
\text { envolvendo o tema reducionismo no estudo da química da água. }\end{array}$ \\
\hline P3 & & $\begin{array}{l}\text { - Aspectos qualitativos e quantitativos na abordagem do equilíbrio químico são igualmente } \\
\text { importantes. } \\
\text { - Importância de reflexões filosóficas envolvendo o tema reducionismo no estudo da } \\
\text { química da água para a compreensão o papel das representações na química e das } \\
\text { propriedades da água. }\end{array}$ \\
\hline P4 & $\begin{array}{lll}\text { - } & \text { Aspectos qualitativos associados à } \\
\text { experimentação. } & \end{array}$ & $\begin{array}{l}\text { - Foco nos aspectos quantitativos associados a alguns assuntos no ensino de química } \\
\text { visando o desenvolvimento do raciocínio lógico, da abstração e a preparação para os } \\
\text { exames vestibulares. } \\
\text { - Importância de reflexões filosóficas envolvendo o tema reducionismo no estudo da } \\
\text { química da água para a compreensão de suas propriedades. } \\
\text { - Interessante abordar as diferenças entre leis na física e na química ao final do primeiro } \\
\text { ano do EM. }\end{array}$ \\
\hline P5 & $\begin{array}{l}\text { - Aspectos qualitativos associados à } \\
\text { experimentação. } \\
\text { - Foco nos aspectos qualitativos ao abordar o } \\
\text { tema equilíbrio químico. } \\
\text { - Atividade experimental envolvendo } \\
\text { classificação de substâncias. } \\
\text { - Relaciona a organização e interação das } \\
\text { partículas com as propriedades dos } \\
\text { materiais. }\end{array}$ & $\begin{array}{l}\text { - Aspectos qualitativos na abordagem do equilíbrio químico são mais relevantes que os } \\
\text { quantitativos; podem favorecer a compreensão de conceitos e fomentar a curiosidade e o } \\
\text { gosto pelo estudo da química. } \\
\text { - } \quad \text { qão há necessidade de abordar explicitamente as diferenças entre as leis na física e na } \\
\text { - Importância de reflexões filosóficas envolvendo o tema reducionismo no estudo da } \\
\text { química da água (junto com a abordagem de massa molar, número de Avogadro e mol) } \\
\text { para a compreensão das propriedades da água. }\end{array}$ \\
\hline
\end{tabular}

Quadro 07: Quadro-resumo das concepções e práticas dos sujeitos entrevistados acerca do tema Reducionismo. 
No decorrer das entrevistas foi possível identificar fatores que afetam as concepções e práticas ${ }^{17}$ dos professores no que tange à inclusão de aspectos da natureza da ciência e, mais especificamente, da natureza da química no ensino. Esses fatores, classificados em externos (relacionados ao contexto) e internos (relativos ao professor), estão organizados no Quadro 08 a seguir.

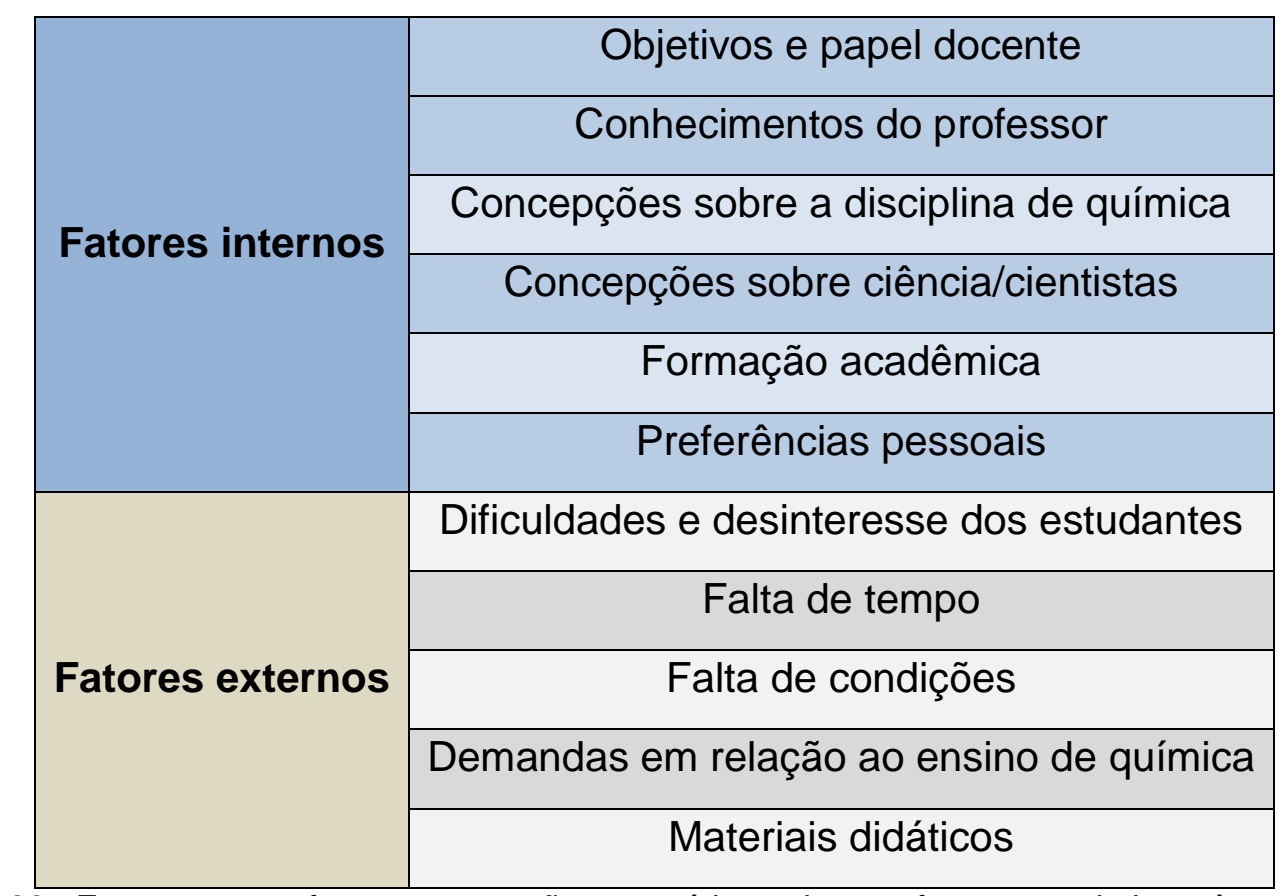

Quadro 08: Fatores que afetam concepções e práticas dos professores relativas à natureza da química.

\subsubsection{Fatores internos}

\subsubsection{Objetivos e papel docente}

Segundo Van Driel et al. (2005), a aceitação de uma inovação curricular é facilitada quando está de acordo com as metas de aprendizagem que os docentes estabelecem pessoalmente. Do mesmo modo, práticas instrucionais e currículos

$17 \mathrm{Na}$ presente investigação não foram realizadas observações das atividades didáticas desenvolvidas pelos sujeitos entrevistados. Referimo-nos aqui à identificação de fatores que levam os docentes a realizar ou não certas discussões, tomando como base suas falas ao relatarem, mesmo que de modo sucinto, algumas de suas práticas com os aspectos discutidos no decorrer das entrevistas. 
opostos às crenças e atitudes docentes concernentes aos objetivos educacionais dificilmente serão aplicados (Höttecke e Silva, 2011).

Em consonância com tais constatações, as falas de alguns docentes sugeriram que seus principais objetivos ao ensinar química também afetam o modo como concebem a abordagem de aspectos da ciência, de modo geral, e da química, em particular.

Embora tenha mencionado as dificuldades e a falta de motivação dos estudantes como principais motivos pelos quais não realizaria determinadas discussões na escola estadual, P1 apontou, no decorrer da entrevista, outro foco ao desenvolver as atividades em sala de aula. No trecho a seguir, ele expôs qual seria seu principal objetivo ao abordar a produção industrial da amônia pelo processo Haber-Bosch. P1 não fez qualquer referência a discussões sobre os múltiplos contextos da química.

Hirayama: (...) você acha que interessaria uma discussão (...) do grande interesse da Alemanha na produção de amô::nia

P1: (...) tenho certeza que você tem que fazer primeiro a parte prática (...) a teoria... não leva... ni/ninguém a nada... nada a ninguém (...)

Hirayama: (...) seria o mais importante dessa (...) parte?

P1: SIM... se você fizesse uma escala nano entende? nanométrica... pequenininha num tubo de ensaio e aí falar "agora vamos discutir" entendeu? a:.: o nitrogênio... inodoro... hidrogênio... ele é... inflamável (...)

Hirayama: (...) se você tivesse que reestruturar (...) você (faria) de uma outra maneira?

P1: a:.: teria que fazer primeiro uma parte prática (...) passaria um filme (...) chama-se "química uma história volátil"... é muito interessante (...) é um vídeo (...) eles fazem tudo em laboratório (...) numa vasilha tipo... uns:: trinta centímetros de diâmetro enche de mercúrio (...) coloca um parafuso... dentro (...) não afunda porque o mercúrio é mais denso... isso sim é interessante (...)

Hirayama: tanto para os alunos do Estado quanto...

P1: (...) como até para os professores... isso é um ensinamento tá? (...) eu vi nesse mesmo... vídeo... eles produzindo hidrogênio... enchendo numa bexiga de gás... e aí a bexiga de gás vai subindo e ele encosta com uma... uma varetinha em brasa e dá uma explosão... eu nunca tinha feito isso... eu gostei... e os alunos olham... eles ficam... né? ou até em bolha de... de/bolha de sabão... detergente... e com hidrogênio... hidrogênio subindo (...) foi com/foi com bolha de/bolha de sabão... e ele vai subindo e ele... enfia lá e brum (...) $\underline{o}$ pessoal olha... se encanta e vê a química (...)

P1: (...) daria para eles cheirarem a amônia para eles saberem o que é que é amônia... não adianta você ficar viajando muito (...) hum/na química é difícil você ficar... imagiNANdo coisas... imagina que...: vai ter uma reação química... não... VEja a reacão química (...)

Para o professor, o mais interessante é considerar os fenômenos impactantes que poderiam encantar os estudantes e fazer com que eles "vejam" a química. 
O foco de P1 em relação aos aspectos fenomenológicos da química também foi identificado em suas falas no que se refere à abordagem de outros assuntos sobre a ciência.

Hirayama: essa discussão de modelos atômicos... o que você acha... P1? você acha importante?

P1: $\underline{\text { não }}$

(...)

Hirayama: por quê?

P1: não leva a nada... não leva a nada

(...)

Hirayama: (...) para a formação de um:: estudante que não vai ser químico (...) você acha que essa discussão é relevante?

P1: olha ele teria que... por si só buscar mais informações... você dá... você dá o:.:tapa inicial... aí fala "bom agora vocês podem ter em tal tal tal lugar porque eu tenho que tratar outras coisas mais importantes"

(...)

P1 (...) ISSO ((modelos atômicos)) aqui seria interessante mostrar num aspecto num vídeo... passaria para eles... "ó... vamos pesquisar em tal lugar na internet" (...)

Hirayama: (...) porque que você trabalharia dessa maneira? (...)

P1: porque aí ele enxerga... ele vê... coisa que ele não tem experimentalmente porque o Rutherford fez isso... ele consegue ver isso aqui

Hirayama: isso para você seria o ideal assim de fazer?

P1: na química sim... tem que ver... o ideal... tem que... VER

Hirayama: e:.:. que é mais importante para você... que os estudantes aprendam sobre essa questão ((equilíbrio químico)) (...)

P1: a reversibilidade... um... um produto né?... tipo reagentes indo para matéria/para... o produto acabado e o produto acabado podendo voltar... através de reciclagem... podendo voltar ao que ele era... reagentes... aí eu falaria em constante de equilíbrio... isso que para mim é importante... eles saberem o desequilíbrio... aí eu falo em/em tê.:.nis... mostro a calça... o têxtil... né? ola roupa que eles estão usando e o desequilíbrio que está sendo formado na Terra (...)

Hirayama: (...) por que que isso seria mais importante para um estudante do ensino médio? P1: por que ele enxerga isso... porque ele enxerga isso aí... se você colocar em outros termos ele não vai conseguir enxergar

Hirayama: é:: então essa você trabalharia nesse sentido?

P1: trabalharia com alguma coisa que é é é é possível você enxergar

Conforme sugerem as falas acima, para $\mathrm{P} 1$, há outras questões mais importantes no ensino de química do que a abordagem dos modelos atômicos históricos. Apesar disso, ele enfatizou que tal assunto ficaria mais interessante se fosse trabalhado por meio de um vídeo, pois, desse modo, os alunos conseguiriam "enxergar" os experimentos associados ao desenvolvimento do modelo de Rutherford. 
No que tange ao tema equilíbrio químico, P1 também destacou a importância de se fornecer aos estudantes exemplos de materiais do cotidiano, pois isso poderia aproximá-los da química e torná-la mais interessante.

Hirayama: (...) dessas atividades que a gente viu aqui ((envolvendo química, tecnologia e
sociedade)) né? (...) você tiraria alguma (...)
$P 1:$ (...) eu colocaria o cotidiano para fazer com que ele se (...) aproximem da.... química....
falaria do co-ti-di-ano... se você foge muito do cotidiano... o aluno... ele... hoje em dia ele é
esperto... ele já vai... vai fazer aquilo que interessa... tá?... o cotidiano é melhor (...)
(...)
$P 1:$ a combustão do álcool combustão do/da/do/da gasolina... uma fábrica que que que você
vê consegue até.... falar sobre alimentos... refrigerante... o que eles têm no dia a dia (...)

No final da entrevista, conforme as falas abaixo sugerem, P1 afirmou que a abordagem de questões acerca do trabalho dos cientistas "desloca" o que é realmente relevante no ensino de química: a visualização de fenômenos e as relações com o cotidiano.

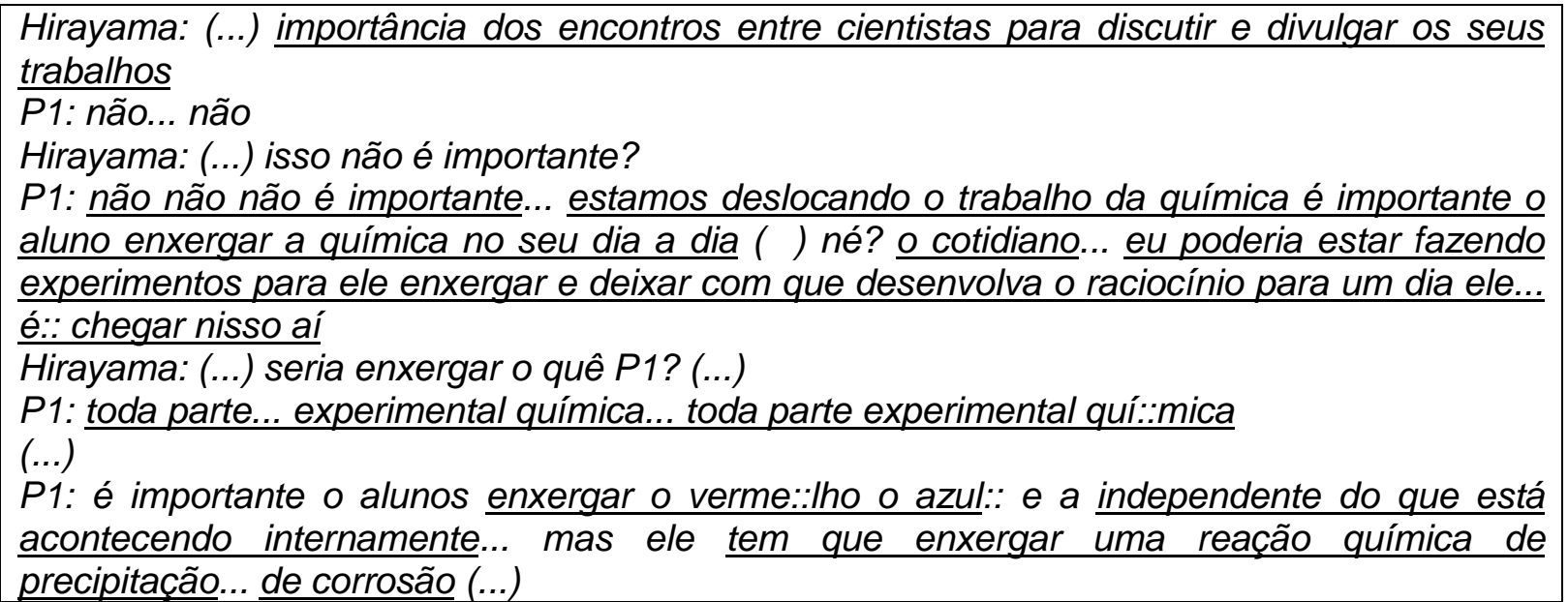

Desse modo, ele retomou algumas ideias que havia apresentado nas entrevistas iniciais.

Hirayama: (...) aponta... ao trabalhar massa (...) as controvérsias que haviam entre os
cientistas né? (...) fala de Dal.:.ton (...) Proust né? você acha que isso é importante? (...)
(...)
P1: eu não daria... eu não daria... pra minha clientela eu não daria... não daria
(...)
$P 1:$ (...) se você fala proteína carboidrato vitamina de tudo ... os alunos ficam assim... eles
comeram isso... aí vai falar massa atômica... perder uma aula... duas... eu falo en passant...
en passant isso aí... entendeu? eu tenho que tornar com que a coisa seja agradável...
amanhã ou depois ele fala "puta... química foi muito ruim" (...) eu não quero taxá-los que a
química é ruim... num quero... quero mostrar as cores pra eles... 
P1: (...) nem eu como professor já há tanto tempo... quando é que eu usei... esse raio dessa atomística na minha vida profissional? NUNCA...imagina para os alunos... então eu prefiro passar uma coisa mais prática entende?... que ficar enrolando (...)

$\mathrm{O}$ trecho acima indica que para $\mathrm{P} 1$, trabalhar com o cotidiano, o imediato, $\mathrm{o}$ prático torna a disciplina agradável para os estudantes. Ademais, de acordo com o docente, a reflexão sobre questões teóricas "não leva a nada" e ainda pode suscitar o desinteresse pela química.

Hirayama: por que você acha que eles não se interessam por ciência? (...)

P1: mostra muita teoria muita teoria... muita teoria não leva... tem que mostrar mais a prática (...)

---

Hirayama: qual que é a tua prioridade então?

P1: mostrar a prática... a prática... toda vez que eu dou aula pra eles eu sempre procuro alguma:.... alguma amostra prática... eu tenho que fazer eles enxergar... se eles enxergarem $\underline{\underline{\text { tudo bem }}(\ldots)}$

O ensino de química sob essa perspectiva fica esvaziado dos aspectos teóricos imprescindíveis para a compreensão dos fenômenos estudados, não havendo, portanto, espaço para a discussão sobre os múltiplos contextos que afetam a construção dos conceitos, teorias e modelos da ciência e da química.

Por meio da análise das falas de P2, também foi possível identificar a influência de suas ideias acerca das finalidades educacionais e do papel docente sobre as práticas e concepções em relação a determinadas discussões sobre a ciência.

Segundo as falas abaixo, para a professora, um dos principais motivos pelos quais é importante a abordagem das implicações éticas decorrentes do desenvolvimento da ciência e tecnologia é desenvolver habilidades de raciocínio, assim como a capacidade de fazer escolhas e tomar decisões.

Hirayama: (...) você acha importante ((discussões das implicações éticas))?

P2: eu acho importante... porque na vida inteira eles vão fazer esse tipo de discussão... para ganhar (...) uma habilidade de raciocínio também conhecimento e (...) que ele possa tomar decisões né? possa fazer escolhas e tal (...)

Nos encontros iniciais, ao comentar sobre a função social do professor de química, P2 já havia mencionado o papel da discussão sobre as interações entre 
ciência e sociedade no desenvolvimento da capacidade de opinar e fazer escolhas relativas à questões científicas e tecnológicas.

Hirayama: (...) qual que você acha que é a função do professor de química hoje (...)?
P2: (...) há um tempo atrás (...) todo mundo só falava do álcool né? (...)
(...)
P2: (...) nas aulas de química a minha cabeça lá com os meus alunos eralera nesse ponto
(...) de repente vem o pré-sal aí vem aquela farra toda né? (...)
P2: assim eu não vou generalizar né? mas eu acho que pouquíssimos alunos estão por
dentro disso ou sabem se posicionar a respeito
----
P2: (...) outro dia um menino falou assim: "ah quer dizer então que o Obama veio aqui”(...)
ninguém vem aqui para bater palma (...) ninguém vem aqui oferecer tecnologia de ponta se
não tem um interesse (...) que que tá movendo tudo isso né?
Hirayama: por que que se acha que isso é importante... trazer esses assuntos?
P2: ué como é que você vai fazer uma votação de qualquer coisa numa sociedade se você
não conhece minimamente daquilo que você tá falando... como é que alguém vem aqui e vai
falar de.... vai "ah... tem uma matéria de/que tá passando no jornal... sobre a distribuição dos
royalties do petróleo e o menino tá assistindo lá e nem sabe do que tá falando lá... nem
vai/não vai saber opinar porque não sabe do que que se tra/do que que tá falando (...)

A finalidade de P2 de formar um cidadão crítico também está relacionada com a relevância que atribui à compreensão da provisoriedade e falibilidade das teorias e dos modelos científicos. Para ela, tal discussão contribui para estimular a criticidade dos estudantes.

P2: (...) meu professor falava que ela é uma teoria ela pode mudar né? ela é suscetível a dúvidas né? a incertezas e tal (...) e eu falo a mesma coisa "(...) isso daqui é uma teoria... ainda é válida... pode mudar? pode... até que a gente coloque tantas dúvidas que tenha tantas incertezas que vem outro modelo e o substitua"... né?

(...)

Hirayama: (...) porque que você trabalha essa?

P2: porque não é uma verdade absoluta (...) eles têm que ter condições para... para pôr em dúvida mesmo para questionar sim... como é que surge uma coisa nova? quando alguém começa a ficar incomodado comecca a questionar a se perguntar (...) porque através de boas perguntas é que se começa a refletir... não é? (...)

Além disso, a professora defendeu a utilização de abordagens históricas no ensino de química visando a formação de sujeitos.

P2: a parte histórica eu acho que ela tem um compromisso com a formação (...) não é só para valorizar quem já passou (...) eu acho que é uma motivação (...)

---

P2: (...) vou voltar de novo na Marie (...) ela sai de uma/um país... va:.: para outro com uma uma outra língua e e aí come::ça a estudar e começa a se despontar e e na/naquela área e tal... existe um esforco muito grande aí... você sair dali ir para um canto... estudar e tal... (...) 
- - tudo bem que a mente dele não era uma mente normal era uma mente/uma mente brilhante... né?... - - mas assim é brilhante porque ela persistiu também ela foi atrás... né?... essas atividades históricas eu acho que elas vão ao encontro da formação... formação de cidadão

$----$

P2: (...) eu acho que nessa hora a preocupação é na formação... que qualquer pessoa se ela tiver dedicação ... se ela estudar... se ela correr atrás ela ela ela pode conseguir (...)

P2: (...) ninguém para para pensar que para você criar um modelinho desse... você abre mão de muito tempo da sua vida mesmo assim para... para fazer esse estudo e tal... isso não é valorizado... né? isso eu acho fundamental assim mostrar que é uma construção humana... e que ele como tal ele também pode mudar isso mas não é assim ((estalou os dedos)) de uma hora pra outra... isso requer tempo... requer trabalho... requer constância... perseguir objetivos (...)

Segundo P2, os conhecimentos científicos são aprimorados no decorrer da história em função do trabalho de cientistas que, por meio do esforço e dedicação, se tornam geniais, contribuindo para o bem-estar da humanidade. Assim, a história da ciência teria como intuito precípuo fornecer aos estudantes exemplos de perseverança.

Entretanto, embora indique a formação de sujeitos como papel do professor e alguns aspectos da formação para a cidadania como objetivos do ensino de química, ao comentar acerca de sua prática, das diferenças entre a escola privada e estadual, bem como a respeito dos conteúdos que considera importantes, a docente P2 revelou que tem também como preocupação a preparação dos estudantes para o Exame Nacional do Ensino Médio (ENEM) e a aprovação deles nos vestibulares

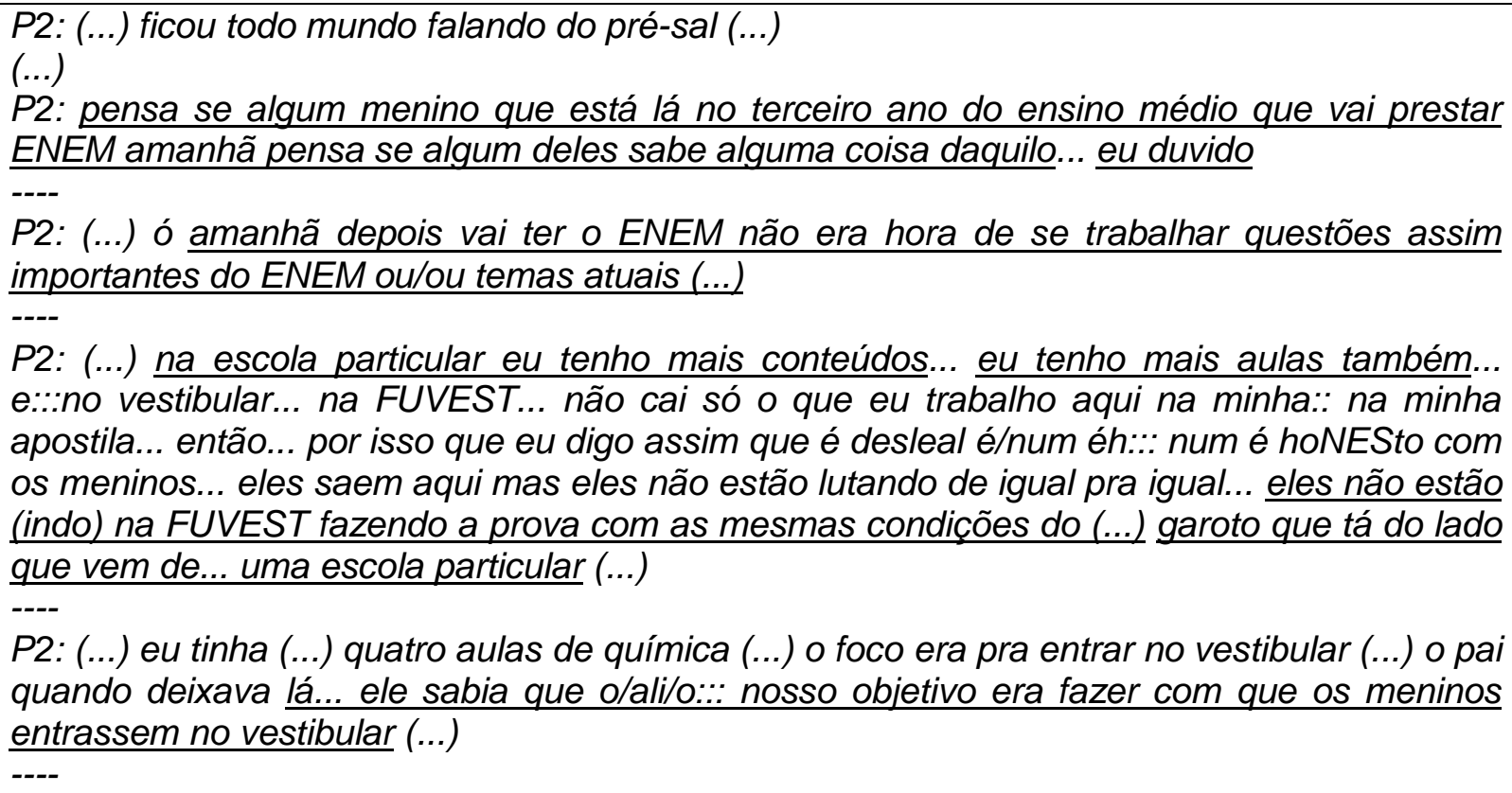

P2: (...) na escola particular eu tenho mais conteúdos... eu tenho mais aulas também... e:::no vestibular... na FUVEST... não cai só o que eu trabalho aqui na minha:: na minha apostila... então... por isso que eu digo assim que é desleal é/num éh:.: num é hoNESto com os meninos... eles saem aqui mas eles não estão lutando de igual pra igual... eles não estão (indo) na FUVEST fazendo a prova com as mesmas condições do (...) garoto que tá do lado que vem de... uma escola particular (...)

----

P2: (...) eu tinha (...) quatro aulas de química (...) o foco era pra entrar no vestibular (...) o pai quando deixava lá... ele sabia que o/ali/o:.: nosso objetivo era fazer com que os meninos entrassem no vestibular (...) 
P2: (...) pra/eu garantir que esses meninos que estão aqui comigo... que ele vá prestar uma Fuvest e que entre na USP eu tenho que ter cota... entendeu? (...)

$---$

P2: (...) ((o livro didático)) do Júlio ((César Foschini Lisboa)) o/o que faz o aluno como protagonista eu acho que ele vai muito ao encontro:: da proposta ((do Estado)) né?

Hirayama: entendi

P2: então ele está muito contextualizado com o CTS também eu acho que é bem bacana né?... é:: tem exercícios porém poucos né? já o ((livro didático)) do ((Tito e)) Canto ele tem muito exercício élos textos eles são bem:: bem sintetizados né? só que ele tem mais exercícios e tem exercícios de ENEM... vestibular então assim

(...)

P2: é... então assim eu fico com:: essa atualidade (em um) eu tenho textos muito bons né? mas os exercícios são um pouco mais... são dele vai vamos pensar assim

P2: (...) nesse bimestre agora eu trabalhei mais com Eduardo Canto porque foi o q/ o que (teve) uma pegada melhor (...)

$(\ldots)$

P2: é eu tenho que priorizar (assim) o que é que eu tenho de tempo... eu tenho duas aulas? então eu tenho que fazer isso né?

Em uma de suas falas no trecho acima, ao expressar a preocupação de que os alunos da rede estadual não tenham os conteúdos necessários para passar no vestibular, a professora demonstrou a relevância que atribui aos temas que são cobrados nessas provas. Ademais, quando citou como vantagem da rede privada sobre a pública a quantidade de conteúdos, a professora também evidenciou o quanto se preocupa em trabalhar com os estudantes uma quantidade razoável de conteúdos cognitivos da química, de modo a prepará-los para as provas de ingresso nas universidades.

Nas falas do último trecho, a professora disse apreciar livros didáticos com uma abordagem Ciência, Tecnologia e Sociedade (CTS). No entanto, apontou que, ultimamente, tem utilizado com mais frequência materiais contendo textos menores e mais exercícios. Assim, apesar de adotar um discurso voltado à formação para a cidadania e considerar a abordagem das relações entre ciência e sociedade importante, a docente também utiliza como critérios, ao escolher um material didático, o fato de ele conter mais atividades de vestibulares e do ENEM, e de permitir trabalhar mais conteúdos em menos tempo.

O objetivo de preparar os estudantes para tais avaliações também foi mencionado pela docente ao apontar a importância de abordar os modelos atômicos e desenvolver a argumentação.

P2: (...) eu acho que é interessante você trabalhar essa coisa dos modelos (...) que isso de alguma maneira vai ser cobrado dele... ou no ENEM... éh... ou no vestibular e tal (...) 
P2: (...) quando ele faz essa relação uma coisa com a outra... no final ele consegue construir um texto... né? argumentar (...) esse confronto de: de ideias... vai melhorando o argumento dele e isso aqui dá condição dele escrever...

Hirayama: (...) você acha importante desenvolver essa argumentação?

P2: sim... sim... ó... pensa... a gente teve esse final de semana agora $0 . .$. ENEM... né? onde é que pega o povo? na escrita... na leitura na interpretação e tudo o mais assim... se cada disciplina fizer isso... né? a gente tem meninos melhores no ENEM por exemplo... não só no ENEM né?

Desse modo, a relevância que a professora atribui a algumas discussões sobre a ciência e a química está também relacionada à presença de tais questões no ENEM e nos vestibulares.

Outra docente que reforçou a sua concepção sobre o papel do professor e os objetivos do ensino de química ao se referir às abordagens sobre aspectos da química e da ciência é P5. Para ela, o principal intuito do ensino de química é motivar os estudantes pela química e o seu estudo.

Hirayama: e você que tem uma experiência vasta em (...) três escolas diferentes né? (...) você quando entra na sala...você tem alguma diferença de papel... "olha meu papel aqui é diferente do que no Estado"... ou não... ou você tem o mesmo (...)?

P5: é criar interesse nos três

----

P5: (...) cada escola tem uma prioridade cada professor vê uma prioridade... a minha prioridade é que o aluno goste de química aprenda química (...)

Como sugerem as falas abaixo, tal finalidade orienta as ações e a opinião da docente em relação às discussões sobre a natureza da química e da ciência consideradas na investigação.

P5: (...) nós falamos né? (...) porque tinha que sair do Chi::le... a dificuldade que estava na época (...) então eu acho muito interessante... isso aí tem que ser dado tem que ser falado sim... para ele ter interesse

P5: (...) eu falo (...) quando teve Rutherford e Bohr (...) eu falo qual era a intenção que ele tinha... né? o que ele queria fazer... e como ele se programou e porquê que deu tudo diferente do que ele imaginava... mas eu não falo de divergências assim... da época...

Hirayama: (...) e você faria isso? você falaria?

P5: falaria... só que... de novo né? eu teria que ler algo... para poder adaptar dentro... da minha matéria

Hirayama: entendi... na verdade tem um texto aqui... com base... (...)

P5: (...) mas mesmo no texto... não tem... eu já conheço assim... lógico... não é tudo... mas não tem assim um... eu não sei como te explicar... é o que eu te falei... eu preciso de ter comigo ALgo que eu possa envolver o aluno e ele prestar atenção no que eu estou falando e gostar do que eu estou falando...

Hirayama: entendi... entendi... entendi... 
P5: e tem muitas coisas por exemplo... dessa parte por exemplo... eles eles nem piscam quando eu vou falar sobre o Rutherford... com o Dalton eles nem ligam muito... nem Thomson... mas na hora que eu comeco a falar sobre o Rutherford e Bohr eles nem pis-cam (...)

Hirayama: em relação a esse assunto você acha que... que você falou que precisa (...)

P5: precisa fazer... que ele... que ele se intere....sse e possa fazer perguntas...

Hirayama: entendi

P5: (...) quando eu explico de Bohr... Rutherford eles adoram... porque vai falar sobre qualquer falou radioatividade o que for qualquer coisa eles gostam não importa (...) eu explico a ideia que ele teve para descobrir o tamanho daquele átomo... "nossa professora"... que eu gosto que eles falam isso aquele nossa... que é porque então eles estão éh:: gostando daquilo ali é interessante

$---$

P5: ah é importante porque senão a gente não vai ter professor de química (...) o que eu vejo é que a maioria não gosta de química (...) não tem o que faça com que eles sintam interesse por aquela matéria... porque não adianta eu chegar aqui e ficar só dando aula (...) eu vou ser uma professora como qualquer outra... agora quando eu venho e eu dou laboratório eu explico eu deixo ELES colocarem a mão na massa... sabe? muda completamente o interesse é outro

P5: qualquer atividade... de de laboratório eu faria com o aluno... contanto né? é aquilo que eu te falei... se desse tu::do que eu acho muito interessante fazer:.... os alunos eles começam a ver a ciência de outra for::ma... eles passam a ter curiosidade querem fazer ma:::is as perguntas são ou::tras eles começam a pensar diferen::te $----$

Hirayama: entendi... o que é mais importante? com qual o intuito... vou perguntar assim... você insere essas ((questões históricas))?

P5: curiosidade... simplesmente curiosidade... não que eu vá cobrar do aluno Hirayama: entendi...

P5: $\underline{\text { curiosidade }}$

Assim, conforme sugere o trecho a seguir, P5 apontou que procura constantemente experimentar novas abordagens, visando promover o interesse dos alunos pela química e seu estudo:

P5: (...) essa da água oxigenada eu comecei a fazer esse ano (...) ah eles amaram então quer dizer que eu já falei "bom ano que vem faço de novo" entendeu?

P5: tudo que eu vejo de novo que eu acho que... tudo que eu acho que para ele vai ser mais interessante e ele vai associar mais do que eu estou falando e tem mais interesse no que eu estou mostrando eu mudo sem pensar... é na hora

Ademais, a docente considerou a necessidade de verificar o potencial de outras discussões na consecução de tal objetivo.

Hirayama: (...) para os seus objetivos do ensino de química... você faria (...) essas discussões sobre... a criatividade na ciên::cia ou a importância do coleti::vo?

P5: como eu nunca fiz eu não sei... eu poderia fazer para experimentar para depois ter uma $\underline{\underline{o p i n i a ̃ o}}$ 
Hirayama: entendi...

P5: porque eu nunca fiz (..) esse tipo de... trabalho com meus alunos de falar e depois fazer uma discussão sobre isso... éh:: eu teria que experimentar primeiro

Hirayama: entendi... mas assim o assunto em si você acha que...?

P5: então... o assunto é lógico que eu iria ler mais... porque eu ia ter que deixar ele mais interessante

As falas de P3 no decorrer das entrevistas também sugerem que suas práticas e opiniões sobre a inclusão de elementos da natureza da ciência no ensino são influenciadas por seus principais objetivos ao ensinar e pelas suas concepções sobre o papel docente. Nos primeiros encontros, P3 fez muitas considerações a respeito das finalidades de se ensinar química no ensino médio. As falas abaixo sugerem que o docente costuma realizar tal reflexão, bem como evidenciam suas angústias e dúvidas em relação ao seu papel como docente.

\begin{tabular}{l} 
P3: (...) ensino de química para que serve? (...) \\
-.- \\
P3: (...) está na $L D B . .$. que esse ensino básico tem que DAR instrumentação... formação... \\
competências e habilidades para o cara se quiser... - - porque não é o único caminho \\
também... - - seguir para o ensino superior... mas você não pode omitir... tirar isso dele... (...) \\
aqui sempre tem essa discussão... então o que é/se não é escola... se não é trabalho... não \\
é universidade... o QUE É/ a escola de ensino médio e não é técnico? (...) então o que que \\
faz com esse cara? (...) então é uma situacão muito complicada... aí acaba termina \\
\hline repetindo o que está na lei... mas tu não sabe fazer lei... EU também não sei
\end{tabular}

Assim, o professor demonstrou dificuldade em definir, de modo inequívoco, a função do ensino de nível médio. Durante o seu discurso, P3 cita diferentes objetivos para a disciplina de química nesse nível de escolaridade.

P3: (...) eu acho que o papel do ensino médio era talvez fazer os meninos entenderem um
pouco da natureza que eles/que eles participam... entendeu... como um cidadão (...) acho
que o ensino médio... se você não se resume a repetição de conteúdo né? (...) você alcança
alguma coisa... nesse sentido... tenta... alguma coisa nesse tipo
--
P3: (...) é o que eu falo para eles... gente... a gente tem que aprender e fazer uso disso ((dos
conhecimentos de química)) para a vida... para entender melhor... para escolher coisas...
para votar... para entender o que está acontecendo... porque esse calor... saber o que eles
dizem... se há contradições com isso... se tem isso... se já parou a discussão (...) então é
$\underline{\text { assim é entender isso também }}$
---- Hirayama: (...) quais seriam os objetivos principais do ensino de química? (...)
P3: (...) para mim é... a constituição dos materiais... as propriedades dos materiais e as
transformações porque eles passam se você pensa que isso vai dar ao aluno um pouco da
consciência do que ele tá vendo ou do que ele é ou do que ele está participando (...) eu
preciso saber historicamente onde eu estou... porque que acontece isso... que acontece
$\underline{\text { hoje na minha sociedade (...) }}$


P3: (...) se posicionar diante de uma né?... vai abrir a fábrica... quer dizer... Parque Augusta... tem gente que quer derrubar o parque... ah eu sou contra... por quê?... ou a favor por quê? (...)

As falas acima indicam que, assim como P2, uma das preocupações do docente P3 ao ensinar química é a formação para a cidadania. Segundo ele, o professor deve ultrapassar um ensino fundamentado na transmissão de conteúdos e contribuir para que os estudantes compreendam o funcionamento da sociedade e as contradições envolvendo temas científicos, se posicionem diante de questões envolvendo a ciência e tecnologia, bem como façam escolhas mais conscientes.

Assim, como sugere o trecho abaixo, um dos principais intuitos de P3 em seu trabalho didático é promover o desenvolvimento da atitude indagadora e da autonomia.

P3: (...) a escola nos moldes em que está... termina CRlando essas pessoas que não conseguem extrapolar um pensamento... criar relações... eles só conseguem RE-PE-TIR... $\underline{R E-P R O-D U-Z I R}$

$---$

Hirayama: (...) descreve uma aula sua (...) que você acha que foi uma aula boa (...)

P3: foi a aula que a menina (...) perguntou (...) "o porque que meus... porque que os átomos do meu corpo não saem"... essa aula foi muito interessante (...)

Hirayama: por quê? (...)

P3: primeiro porque ela teve a indagação e segundo porque ela teve a coragem de se expor. (...) porque para mim foi bom porque ela entendeu o espírito da aula e agora eu acho que ela anda né?... com as próprias pernas... ela pode não entender (...) de química... mas pelo menos uma atitude de (indagadora)... observadora... é de exposição... do pensamento que sai um pouco do que está dentro da escola (...)

De modo a alcançar tais objetivos, durante toda a entrevista, P3 apontou reiteradamente a importância de atividades que permitam a construção de conhecimentos, assim como a compreensão sobre a maneira como tais conhecimentos foram elaborados.

Hirayama: você acha importante que eles façam ((seus próprios modelos))?

P3: ah.... sem dúvida... construção né? (...)

Hirayama: mas a importância? você atribui importância a essa discussão ((acerca do processo de modelagem))?

P3: a qualquer discussão que haja construção de conhecimentos eu acho... e de entendimento da construção... (...)

(...)

Hirayama: mas você acha que é importante por quê?

P3: de novo... construção de conhecimento... construção de conhecimento... de entender 
como esse conhecimento foi cons/por que está aí né? eu... eu acho super importante... $----$

P3 : (...) é::: legal quando a prática vem para - - não para justificar um conceito - - mas talvez para construir... alguma coisa... tirar uma dúvida... levantar um questionamento (...) ---

Hirayama: quais seriam os objetivos (...) ao inserir essas atividades ((experimentais))?

P3: (...) vou ser bem genérico... é construção do conhecimento (...) eu acho que é... é para construir conhecimento... de toda natureza inclusive... inclusive operacional né (...)

----

Hirayama: vamos tentar ser mais especifico (...) qual é o seu objetivo com um aluno? o que é importante que esse aluno desenvolva... por meio das atividades experimentais?

P3: (...) pensamento... pensar construir relacionar extrapolar... é isso... para mim é isso assim... seja o que for... seja uma leitura... seja uma observação de algum fenômeno... seja... seja na aula... na aula... tradicional... seja numa videoaula... seja num... num gráfico...

Para P3, no processo de ensino e aprendizagem, o professor atuaria apenas como orientador, sugerindo questões e motivando a participação ativa dos alunos nas atividades propostas. Aos estudantes, por sua vez, caberia corresponder aos estímulos do professor, fazer pesquisas e compartilhar seus conhecimentos com a turma.

P3: (...) eles não se interessam por QUAse nada e também não depende dos professores... (...) a gente não tem que motivar ninguém... de jeito nenhum ... eu não estou aqui para isso... (...) e o médio é ele quem tem que arrumar motivação para estar aqui (...) se a própria mãe não consegue... se a própria família não consegue (...) como é que eu vou motivar um cara desse (...)

----

P3: (...) acho que quando isso ((atitude indagadora)) acontece acho legal... importante... sair de dentro da sala e o sair de dentro da sala (...) ela simplesmente foi... CLARO porque ELA se habilitou... não fui eu quem fiz isso ela se sentiu a vontade por algum motivo e foi... porque a gente não faz isso com ninguém... ninguém consegue fazer isso... você abre uma perspectiva se ele se sentir a vontade ai ele vai e se tiver interesse né (...)

Desse modo, para P3, o interesse pelas situações pedagógicas propostas é um fator preponderante para a construção de conhecimento e depende mais do aluno que do professor. Como se depara com a falta de motivação e as dificuldades dos estudantes em seu contexto de trabalho, o docente não aprofunda determinadas discussões em sala de aula, e acredita que determinadas discussões, embora relevantes, não serão bem-sucedidas na escola onde atua.

P3: aí eu falo "mil oitocentos e oito"... as vezes eu falo... eu desisti "mil oitocentos e oito é uma data importante na história do Brasil alguém sabe alguma?" "ahn? quê?" "ah a chegada da Família Real" "isso tem alguma mudança na ciência... para gente? na vida da gente?" "ahn?" "está bom... deixa passa... quem quiser pesquisa" aí volto pra minha aula 
Hirayama: (...) você costuma trabalhar (...) com as questões dos modelos? (...)

P3: (...) a gente trabalha com modelo de Dalton... diz "olha esse não é o último modelo esse modelo não explica tudo mas ele serve aqui... existe outro"... aí você pergunta qual é o modelo que se estuda? que é o Rutherford... também não rola... mas falo... falo sempre $---$

Hirayama: (...) quando você (...) pensa... ah vou dar essa aula... ((acerca das propriedades da água)) qual o objetivo que você tem em mente

(...)

P3: aqui nesse caso as ligacões entre as moléculas (...) têm que entender (...) as coisas são como são... a ciência apenas tenta expliCAR:: a situação... então saber da propriedade material é fundamental para reconhecer o mundo $E$ ajudar na... no entendimento cientifico... e aí... mas... burros $n$ 'água isso aqui gente (...)

(...)

Hirayama: e a questão do:: do/da... a discussão entre:: o:: a propriedade e a relação com a:: com a...?

P3: com a estrutura?

Hirayama: com as interações intermoleculares... é possível?

P3: ((risos)) claro que não (...) muitas vezes eu faço isso - - "açúcar... sal... são substâncias... muito parecidas... descreve para mim as propriedades semelhantes e as diferenças"... opa... você leva uma hora e meia... para tirar isso (...) os alunos que a gente vê aí fora... não representa essa construção de conhecimento todo aqui não

No decorrer das entrevistas, P3 apontou ainda que não abordaria determinadas questões específicas sobre a experimentação química no ensino médio.

Hirayama: (...) as funções dos experimentos... na química (...) as principais atividades dos químicos... o papel das teorias na experimentação em química... e o papel dos instrumentos da pesquisa QUÍmica... essas discussões. (...) você acha que são relevantes para os estudantes... ou não?

P3: não... do ensino médio não... eu não acho relevante...

Hirayama: por quê?

P3: (...) porque isso parece ser continuidade... isso não é fundamental para eles (...) já foi dito as funções do experimento é feita a medida que você faz (...) essa parte aqui... a/a:.: "as principais atividade da química atualmente" (...) é perder tempo para mim porque... se eles têm interesse diante de tudo que você fez... tão... tão... tão profundo com tanta verticalização ele vai procurar saber isso... eu acho que também tem que abrir espaço para o aluno sabe?

(...)

P3: eu acho que isso aqui é um é o papai pegando na mão demais assim... se você já fez tudo aquilo... é natural que... o trabalho... que é aí onde eu acho que onde possa haver motivação não tenho que motivar ninquém para aprender (...) eu acho que as atividades... se ele realizar com eficácia... se elas tiverem algum fundamento... vai mexer... com 0 aluno... e aí pode ser que ele procure saber "porra mas o que é o que o químico faz meu Deus? (vou) olhar um direitinho" e.: o papel das teorias na experimentação (...)

Para ele, abordar a função dos experimentos da química e o trabalho dos químicos atualmente não é fundamental na formação dos estudantes. Ademais, afirmou que a discussão de tais questões envolve conduzir demasiadamente a 
atenção dos estudantes para assuntos sobre as quais eles deveriam buscar autonomamente, caso desenvolvam o interesse pelo estudo da química.

$\mathrm{P} 4$, embora tenha apontado, dentre outros objetivos específicos, despertar o interesse dos estudantes, compreender conceitos, assim como desenvolver a criticidade e o raciocínio matemático, ao comentar acerca dos aspectos abordados na pesquisa, não mencionou de maneira explícita sua principal finalidade ao ensinar química. Assim, não foi possível identificar a influência direta desse fator nas suas práticas e concepções.

Em relação à abordagem de determinadas questões, P4 apresentou uma perspectiva mais pragmática. Em geral, suas falas sugerem uma preocupação precípua com as maneiras pelas quais poderia superar alguns obstáculos que encontra no seu cotidiano, de forma que seja possível desenvolver as discussões propostas. Por exemplo, nas falas a seguir, mesmo quando questionada acerca da importância de determinadas abordagens, a docente não fez considerações a respeito, mas procurou descrever quais procedimentos faz ou faria para que os estudantes realizem as atividades propostas.

Hirayama: e essa discussão que tem na parte histórica... você acha que é importante?
P4: eu peço para eles fazerem pergunta em sala... é tudo mercenário né? você tem que...
((risos))... só faz se valer nota... então eu peço para eles fazerem tiro um dia lá... depois de
explicar eu junto os três textos e faço questões para eles como é que foi a evolução do
processo... as modificações e essa última aqui ((leitura e análise do texto - Produção
industrial da amônia pelo processo Haber-Bosch - Parte IIl, da Atividade A))
----
Hirayama: (...) é uma discussão importante para formação dos alunos? essa como os
modelos são elaborados na ciência? qual é o papel dos cientistas?
P4: (...) eu procuraria passar um documentário um vídeo pequeno que mostra algumas
coisas e... depois... pedir pra eles fazer um... fazer uma discussão... mas mostrar alguma
coisa visual para eles antes... procurar uma... alguma coisa para... primeiro eles assistirem e
depois mostrar... só... conversar... só você conversando acho que não motiva eles a...

A professora também comentou quais seriam os momentos e os modos mais adequados para se abordar determinados assuntos discutidos no decorrer das entrevistas, tomando por base as características dos estudantes da escola onde atua, do currículo e do material didático da rede estadual.

Hirayama: você faria alguma... alguma dessas discussões em sala de aula? dessa... dessa da tabela periódica? dessa ideia da construção?

P4: poderia tentar... nunca fiz não... só mostra em geral isso aqui eu peço para fazer como se fosse um trabalho... ( ) é uma época meio corrida de segundo bimestre... tem muito 
conteúdo para dar... muitas vezes eu peço pra fazer um trabalho de pesquisa e eles... muitas vezes faz só recorte e cole... não sei se eles... poderia dar um fechamento depois né? poderia pedir que eles fizessem um trabalho de pesquisa e depois faz uma aula de fechamento de assunto... porque a gente não tem isso no texto né? e eles para fazerem isso tem que consultar mais de um livro também... né? (...)

Hirayama: (...) e essa leitura de texto o professor utilizaria um texto histórico né? que ele fala sobre uma disputa... que teve uma disputa da água ser $\mathrm{HO}$ ou $\mathrm{H}_{2} \mathrm{O}$ né?

(...)

P4: (...) no livrinho um do primeiro ano eles falam lá (...) de modelo de Dalton porque eles vão aprender modelo atômico no segundo ano (...) aí ele representava a água assim né? ((escreve em uma folha)) aí eles costuma perguntar "por que está escrito errado lá?" né? (...) essa partezinha às vezes eu gostaria que ela estivesse no comeco do do segundo ano e não no fim do primeiro porque quando eles voltam eles já esqueceram...

Hirayama: entendi...

P4: aí você poderia pegar essa parte aqui você podia... né?... vol/não voltar lá e colocar ele no início do se/do livro do segundo ano e eles virem aí e ( ) poderia encaixar esse aqui lá... (...).

Hirayama: por que você acha que poderia ser interessante isso?

P4: primeiro no começo do ano assim eles estão mais descansados tão mais alegres como não fizeram prova ainda então até você consegue tirar algumas coisas deles aí depois começa a encher de prova exercício um monte de atividade para fazer... aí você tem que ficar... fazendo as trocas né? barganhando "você faz isso por causa daquilo"... é capaz de legal... de.... de... capaz de produzirem alguma coisa assim no início de segundo ano isso aí... se deixar isso para o final de primeiro ano acho que eles já não querem mais saber... final do ano agora eles só querem fazer o que precisa para passar de ano... e se já passaram com você nem presta atenção (...)

Essas falas sugerem que a professora se mostra mais preocupada com as atitudes dos alunos, em termos de realizarem as atividades propostas, do que em refletir a respeito da importância ou dos objetivos das atividades.

\subsubsection{Conhecimentos do professor}

Entre os fatores associados à inclusão das relações entre química e sociedade no ensino foi apontada a falta de conhecimentos necessários para se incluir perspectivas humanísticas no ensino de química, conforme sugerem as falas de P2, a seguir.

Hirayama: (..) interesse da Alemanha né? na produção da amônia no início do século vinte e aí o professor fornece aos alunos mais informações sobre aquele contexto (...)

(...)

Hirayama: e discute as demandas...

(...)

Hirayama: você acha interessante nesse caso fazer ess/esse tipo de discussão?

P2: (...) então aqui daria um trabalho com... uma discussão mesmo com o professor de história... sabe assim? aquela hora que você fala assim "olha... vamos... sei lá... vamos parar essa semana e vamos parar para fazer essa discussão aqui" e seu/eu não digo assim 
fazer um projeto mas não isso ser alguma/uma coisa corriqueira de em momentos você poder trabalhar com/com o colega... lá na outra escola que eu trabalhava eu tinha muito isso com a G. - - que era professora de história (...)

com

Hirayama: (...) para o seu objetivo assim que você tem com os estudantes essa seria uma discussão importante para você?

P2: seria mas eu digo que eu... como química eu não daria conta de... de... éh.: contextualizar o momento político o momento histórico assim... eu... ia ficar assim... a minha leitura ia ser muito superficial...

Hirayama: entendi...

P2: então por isso que eu acho que é fundamental ter um parceiro que conheça outra história para um complementar o outro... é a mesma coisa quando você vai falar da bomba atômica... né? se você não tiver um camarada ali da área de história que situ::a né? vai ficar assim como uma mera descoberta... né? e não é

Segundo a docente, para abordar os contextos associados ao desenvolvimento científico e tecnológico, de modo mais aprofundado, seria necessário o estabelecimento de parcerias com professores da disciplina de história, pois considera que seu repertório de conhecimentos a respeito não vai além do superficial.

Buehl e Beck (2015) consideram que a falta de conhecimento dos conteúdos ou do conhecimento pedagógico dos conteúdos pode levar o professor a não atuar de acordo com as suas concepções acerca de diferentes temas ou metodologias. Como exemplo, essas pesquisadoras apontam um estudo com professores de física em formação. Embora apresentassem crenças positivas sobre o construtivismo no ensino de física, a falta de conhecimento dos conteúdos, bem como dos conhecimentos e habilidades necessárias para a implementação de atividades construtivistas, dificultou a inclusão dessa perspectiva em suas práticas. A fala de P2 sugere que, se se pretende que temas transversais e abordagens interdisciplinares sejam efetivamente incorporadas à realidade da escola, é preciso que os professores sejam adequadamente instrumentalizados para atuar nessa perspectiva.

\subsubsection{Concepções sobre a disciplina de química}

Um dos fatores que influenciam a ideia dos docentes P1 e P3 sobre a abordagem das interações entre química, tecnologia, sociedade e ambiente são as suas concepções a respeito de quais conteúdos fazem parte da disciplina de química. 
$\mathrm{P} 1$, ao se referir às discussões a respeito dos aspectos que influenciaram o processo Haber-Bosch de obtenção de amônia, apontou que desenvolveria esse trabalho apenas na escola técnica, no ETIM (ensino técnico integrado ao médio) ${ }^{18}$, em uma disciplina própria para se abordar tais questões, como história da química.

Hirayama: (...) se tivesse (...) no caderno essa discussão ((sobre o interesse da Alemanha na produção industrial de amônia e o contexto da época)) você faria essa discussão? (...) aqui você faria uma discussão dessa? aqui na ETEC por exemplo?

P1: faria... mas dependendo do do/do:.:da da disciplina (...) que aqui ((na ETEC)) nós temos... várias disciplinas (...) então conforme a discipli::na eu faria... mas num curso de ensino médio... não dá para... isso aí daria até para fazer em história

P1: (...) entende? em história... aplicada junto com a química daria para trabalhar... mas não puramente na química

(...)

P1: na escola estadual...não a/não teria condições para aplicar... aqui no ETIM ((ensino técnico integrado ao médio)) seria interessante... ensino técnico integrado... só:... (...)

As falas acima sugerem que, para $\mathrm{P} 1$, esses assuntos não são básicos para a aprendizagem em química. Seriam apenas conteúdos acessórios e ocasionais que não fazem parte dos conteúdos próprios da disciplina, ou seriam apropriados somente para profissionais da área.

P3 também apresenta uma ideia semelhante, conforme o trecho abaixo sugere.

Hirayama: (...) discutir com o aluno ( ) essa interdependência entre a química e a tecnologia ou... a questão da/a relação entre a pesquisa básica e aplicada... você acha importante (...)? P3: (...) acho mais importante do que conteúdo... porém:: (...) você faz um trabalho desse... sério... uma aula que na verdade são duas né? são noventa minutos... não tem como... se sério também fosse para eles entendeu? (...) porque aí entra uma grande discussão minha assim... eu podia fazer um trabalho inteiro assim... eu adoro isso... mas o conteúdo eu não ia trabalhar

(...)

Hirayama: mas você acha que é importante?

P3: eu acho mas entra aí entra a questão que eu sempre tenho... o que que é importante? a gente... trabalhar os conteúdos todos... apontar os conteúdos todos com todas as relações de interdisciplinaridade... com todas essas questões intersociais... ou a gente... fazer tudo isso com o mínimo de conteúdo possível? eu nunca tenho essa resposta... por quê?

(...)

P3: (...) eu faria tudo isso ((as discussões)) agora... ISSO impõe a você fazer escolhas que é... abrir mão do conteúdo...

$(\ldots)$

P3: (...) e aí óbvio para você trabalhar isso requer um tempo... e aí que você tem que abdicar... conteúdo ou é são outras relações? (...)

18 O Ensino Técnico Integrado ao Médio é uma modalidade de curso oferecido pelo Centro Paula Souza no Estado de São Paulo, o qual permite que o estudante curse, em período integral e de modo concomitante, o ensino médio e o técnico. 
Mesmo considerando relevante para a formação dos estudantes a discussão sobre as complexas interações existentes entre a química e a sociedade, P3 tem dúvidas se deve incluí-las ou não em sua prática, pois para ele o trabalho com tais questões excluiria a abordagem dos conteúdos próprios do componente curricular química, em função do pouco número de aulas semanais.

Desse modo, as falas dos docentes sugerem que eles compreendem como conteúdos próprios da disciplina de química somente o que Zabala (1998) denomina como conteúdos conceituais e factuais, ou seja, os fatos, fenômenos, símbolos, teorias e leis. Desse modo, desconsideram que procedimentos, atitudes, valores e princípios - os quais envolvem, em alguma medida, a participação dos estudantes em processos semelhantes àqueles pelos quais os conhecimentos científicos foram e são desenvolvidos, bem como o reconhecimento dos múltiplos contextos que afetam o desenvolvimento científico e tecnológico - também fazem parte dos conteúdos escolares e, assim, devem ser ensinados de modo integrado com conteúdos de outra natureza.

Ainda no que se refere às concepções dos sujeitos entrevistados sobre a química escolar, P2, ao explicar por qual motivo tem como foco os aspectos qualitativos na consideração de determinados conteúdos, mencionou que os cálculos não são a essência da disciplina de química.

P2: (...) química não é só fazer conta... não é cálculo só... tudo bem precisa fazer precisa entender precisa entender proporções éh... calcular a massa calcular isso tal... precisa mas não é o cerne não é mais importante

(...)

P2: em qualquer área da química... em qualquer conteúdo em qualquer conteúdo seja trabalhando na química orgânica na analítica na inorgânica... qualquer área assim... para mim o cálculo é importante... ponto... mas não é o não é a essência da/da/da química

Para a docente, o mais importante é fomentar a compreensão dos estudantes acerca dos conceitos comumente discutidos no ensino médio, tais como reações químicas e forças intermoleculares, bem como a respeito de algumas relações entre ciência, tecnologia e sociedade.

\subsubsection{Concepções sobre ciência/cientistas}


A influência de concepções acerca da ciência e dos cientistas foi identificada somente nas considerações de P2 em relação à abordagem de questões históricas. De acordo com a professora, a evolução da ciência se dá mediante o trabalho árduo de cientistas brilhantes, com mentes especiais. P2 apontou ainda que a criação dos modelos científicos foi possível em função dessa genialidade.

P2: (...) criar modelos para justificar uma... para argumentar... para explicar aquilo que você está defendendo... é muito difícil mesmo... você tem que ter uma cabeça especial para isso... né? (...) pensa no Dalton (...) no Rutherford (...) no Bohr... né? você tem... tem que ter uma mente especial (...)

Como sugerem as falas abaixo, para ela, os estudantes possuem mentes normais e, desse modo, ela não teria as condições necessárias para propor a elaboração de modelos em sala de aula, embora considere interessante e desenvolva atividades semelhantes no ensino fundamental.

P2: e eles ((os cientistas)) criaram ((modelos)) (...) então eu digo que não são mentes comuns são mentes especiais mesmo e eu não tenho mentes especiais... né? eu tenho mentes NORmais... né?

$---$

P2: (...) eu li uma vez um material do Paul Feyerabend (...) defende uma... uma construção mais dialética aquela coisa toda né? (...) eu não vejo menino... em nenhuma rede... de quinze anos... hoje... éh:: discutindo esse modelo...

P2: (...) eu posso achar isso importante... como professora... éh éh:: como da área da ciência... por defender isso... por acreditar nisso e tudo o mais... mas eu não vejo... éh:.... que eu tenha força de passar isso para um adolescente ---

Hirayama: (...) por que você acha que não tem como você falou "não tenho força"? (...) P2: éh... eu não tenho força assim... primeiro assim... eu acreDITO... até certo ponto... né? $\underline{e}$ eu não vejo que... que eu vá conseguir convencer alguém que isso é uma construção huMANA... né? e de que a partir daqui que ELE pode criar outros modelos também né?

Hirayama: entendi

P2: né? eu não sei se eu tenho essa condição de fazer... não sei não... eu não tenho essa condição de criar... a menos que eu tivesse uma mente brilhante ali... né? e eu acho que eu não tenho mentes brilhantes eu tenho mentes normais

Apesar disso, em outro momento da entrevista, P2 explicou que cientistas como Marie Curie possuíam mentes especiais em função da persistência e constância nos estudos. Ademais, defendeu a abordagem da provisoriedade dos modelos científicos e da dimensão coletiva do trabalho científico como forma de valorizar tais cientistas, que teriam abdicado de seus interesses pessoais em prol de desenvolver ideias que pudessem "facilitar" a vida das pessoas. 
Tomando por base tais concepções, P2 enfatizou o papel da abordagem histórica na formação do cidadão: fornecer exemplos de dedicação e perseverança por meio dos quais os estudantes possam se conscientizar da relevância do esforço para a superação de dificuldades e a conquista de objetivos.

Hirayama: (...) essas atividades é:: envolvendo aspectos históricos (...)

P2: (...) eu gosto disso sim... porque a gente tem que (...) dar a devida importância a quem fez... né? (...) o tempo que a gente abre (...) não tem vida social e tal... em troca de fazer uma atividade... para servir... né? tudo bem você ganha um título... mas é uma atividade para a/a serviço de alguém em serviço de alquém ou de várias pessoas né? (...) e quando se valori/quando se conta se coloca isso na história... ( ) valoriza quem fez é dar esse devido:: cré::dito "olha o fulano abriu mão de várias horas da vida dele para... para hoje eu estar com esse conforto aqui na minha mão"?

$-{ }^{-1}$

P2: (...) vou voltar de novo na Marie (...) quando você pega a/a história dela que ela sai de uma/um país... va.:i para outro com uma uma outra língua e e aí come.::ca a estudar $e$ começa a se despontar (...) existe um esforço muito grande aí (...) e ela era o quê? era uma pessoa normal (...) - - tudo bem que a mente dela não era uma mente normal era uma mente/uma mente brilhante... né?...- - mas assim é brilhante porque ela persistiu também ela foi atrás... né?... essas atividades históricas eu acho que elas vão ao encontro da formação... formação de cidadão

\subsubsection{Formação acadêmica}

P3 foi o único docente que destacou a importância de discutir com os estudantes questões sobre ciência e o trabalho dos cientistas, de modo explícito.

P3: tem (...) um livro (...) que ele tem vários pequenos textos que abrem a::: sempre é... por exemplo página assim os cientistas são malucos?... para discutir quem faz ciência... quais são as características de quem faz ciências (...)

(...)

P3: eu faço isso com o magistério... porque eu tenho um primeiro ano... acho importante para introduzir a esse conceito de ciências o que é quem faz ciências nas ciências se faz na escola... ou... na escola se faz ciências... hoje se reproduz a ciência... o que é fazer ciência... tem toda essa discussão... que eu acho que todo mundo deveria entender isso $----$

Hirayama: por exemplo quem não vai ser cientista na escola a discussão sobre ciência é importante?

P3: claro sem dúvida... porque você sabe como ela é feita... sabe onde ela é feita... sabe por-que que ela é feita... QUEM tá fazendo... porque está fazendo (...)

Ao opinar acerca da inserção de questões históricas no ensino, P3 também apontou a importância de abordar de que maneira "pensou-se a ciência", de modo que os estudantes compreendam o funcionamento do empreendimento científico. 
Hirayama: (...) essa questão então do:: essa discussão dos modelos históricos... você:: qual sua opinião sobre ela?

P3: ah ajuda né?... ajuda a pensar como pensou-se a ciência (...) você acompanha a... as descobertas cientificas que vão mudando os modelos... isso é interessante para eles entenderem até como funciona a ciência

Para o professor P3, tal entendimento é importante, pois pode conscientizar os alunos da possibilidade ou necessidade de se mudar a perspectiva acerca da realidade, em função da aquisição de novos conhecimentos. Hirayama: você diz que.: é importante para entender o funcionamento da ciência... né?
P3: do processo científico... é...
Hirayama: (...) por que você acha que entender isso é importante... na sua visão?
P3: (...) acho importante para o ensino da ciência química ou da ciência em si... essa
construção... dessa percepcão que você tem que mudar... aí é importante até pro
aprendizado... ó estou recebendo informações novas tenho que mudar... mudar a
perspectiva?

P3 relacionou essa questão da mudança e da relevância de se considerar com os alunos questões sobre o trabalho científico à sua formação como ator.

Hirayama: ( ) por que você acha ((importante discussões sobre a ciência))?

P3: porque você vai estudar ciências... porque você vai estar trabalhando dentro de um... é a mesma coisa de você fazer teatro... que é a discussão de um material que tem aqui de um projeto que tem aqui... sem discutir os teóricos do teatro... como eles pensam sobre... como é fazer teatro... você pode fazer tudo diferente... quer mudar você precisa conhecer o que é

Conforme sugerem as falas a seguir, de acordo com o docente, as discussões e reflexões filosóficas sobre a natureza das artes cênicas, que realizou no curso de Comunicação das Artes do Corpo, mudaram sua visão de mundo.

P3: o FOco... o forte de lá é a pesquisa... é o EStudo sobre a arte cênica (...) aí entrei na performance... e daí isso muda... a PUC mudou minha visão de mundo e mudou minha escola... e minha vida aqui... o meu trabalho aqui

Hirayama: e você fala que mudou a visão de mundo por quê?

P3: porque o curso propõe isso assim... o olhar sobre... a construcãa do... do performer... do ator... do bailarino... do diretor e isso faz você pensar o mundo né? assim

Hirayama: ahn

P3: (...) como o curso é muito fundamentado MUlto na questão filosófica... aí isso fez... me abriu melhor... os caminhos (...) entendi melhor o teatro... o que eu quero... o que eu faco então... e muda a aula... porque quando você muda sua vida... muda (...) aí muda com o teu jeito de lidar com as coisas

----

P3: (...) o papel do professor é... é como o meu na graduação... na/na/na PUC... eu fui aluno na PUC e os professores tiveram papel fundamental na mudança da minha vida... $e$ obviamente muda parece muito vago mas não eu estou falando da minha vida quanto 
profissional... em vários nichos que estou né? (...) eu acho que... a universidade os professores das universidades que tem aquela pro/que a proposta lá lá é filosófica é entender as artes cênicas

$----$

P3: (...) essas mudanças todas apareceram depois do curso da PUC... depois do ( )... eu acho um pouco a ideia de você compreender o conjunto de coisas... daquele... daquele ponto... daquele tema que você está estudando... para você poder mudar ou manter uma escolha... mas se você escolhe manter... você sabe como mudar

Em uma das falas acima, o docente revela o intuito de transformar a vida dos estudantes assim como os seus professores, na graduação, contribuíram para que ele mudasse a dele próprio, mediante a reflexão sobre o objeto de estudo. Desse modo, um dos fatores que influenciam o docente P3 em sua posição a respeito da importância das discussões acerca da ciência e do trabalho dos cientistas é a sua formação no curso de Comunicação das Artes do Corpo.

As falas de P4 durante as entrevistas também sugeriram a influência de sua formação em relação a alguns aspectos sobre a ciência. Dos sujeitos entrevistados, a docente, que é formada em engenharia, foi a que mais se referiu à importância de se abordar aspectos quantitativos associados aos conteúdos da disciplina de química e à necessidade de os estudantes desenvolverem, por meio do estudo da matemática, o raciocínio lógico, assim como a capacidade de abstração e análise.

Ademais, apesar de ter apontado a importância da compreensão do desenvolvimento da ciência, ao ser questionada acerca de quais estratégias seriam mais adequadas para se discutir questões históricas, P4 apontou a utilização de vídeos e deu mais ênfase aos processos envolvidos na produção de materiais do que à compreensão da complexidade da construção da ciência.

\footnotetext{
Hirayama: (...) qual seria a maneira ideal de trabalhar essas questões históricas para você? P4: (...) pôr esse pessoal para fazer uns vídeos aí (...) que pudesse ser utilizada pedagogicamente (...)

Hirayama: e aí... o que seria importante que os alunos vissem nesses vídeos (...)

P4: por exemplo (...) como é que foi que eles fizeram a pilha? (...) como que é uma bateria... como é uma pilha... né? (...)

(...)

P4: como é que é feito... eles não têm ideia de como é feita uma pesquisa de como se você chega a um remédio a partir de que você partiu disso? todas as... são mUltas etapas... até chegar a um remédio (...) aí produtos que podem ser tirados da água do mar... aí vem os derivados do sódio e do cloro aí tem produtos de limpeza tinta explosivo... ácido nítrico (...) eles verem a sequência é isso e isso... pega a áqua do mar purifica separa faz eletrólise... isso é legal pra eles entenderem...

(...)

P4: assim... montado de uma maneira lógica... não precisou descer a fundo nos detalhes de química mas fala... fez produto de limpeza fez isso fez... entendeu?
} 
$(\ldots)$

P4: tem que estar isso na na:: como fluxograma... como exercício... e ter uma pequena história... o processo Solvay... isso é legal

(...)

P4: poderia fazer isso para amônia (...) uma sequência lógica um fluxograma... isso isso... $\underline{e}$ no final o que a amônia é utilizada não tem isso (...) eu sou engenheira então eu sou a gente é treinada em fazer isso... engenheiro químico é treinado... qualquer coisa você aprende a montar um fluxograma de qualquer coisa para ter uma sequência lógica... para você encontrar as melhores... maneiras de fazer isso num projeto né? (...)

\subsubsection{Preferências pessoais}

Para P2, um dos fatores que influencia a escolha de atividades por parte do professor é a preferência por determinados conteúdos e a facilidade de desenvolvêlos.

P2: (...) acho que é tão difícil para o professor ficar selecionando eu acho que vai muito da/daquilo que (...) é a facilidade do professor e aquilo que ele mais gosta... quando por exemplo você tem que eleger... o que que vai ser (...) melhor para os alunos eu não tenho dúvida nenhuma que entra o seu gosto pessoal... se tivesse um outro professor de química aqui do lado e você tivesse fazendo (...) a mesma pergunta... ele certamente ia ter outras questões para falar... e/e com certeza essas questões eram mais fáceis para ele mais interessan:.:.tes e tudo o mais né? então vai muito daquilo que você... gosta também né?

Ao declarar porque não abordaria o tema reducionismo relacionado ao estudo da química da água, apontou que não havia gostado da atividade e, portanto, não a aplicaria para seus estudantes.

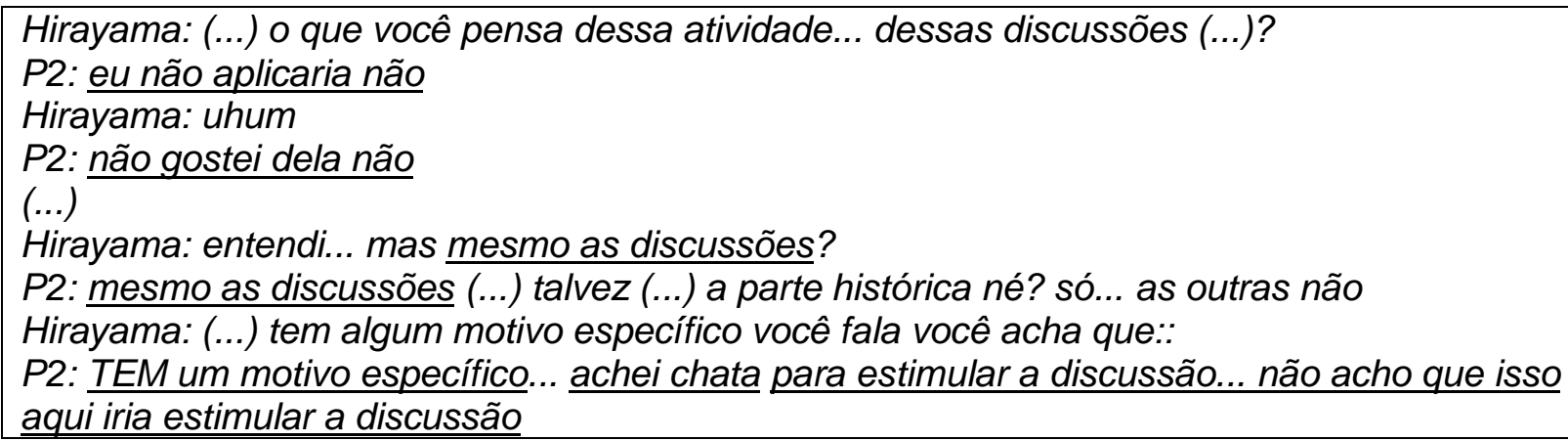

\subsubsection{Fatores externos}

3.2.2.1. Dificuldades e desinteresse dos estudantes 
Um dos principais obstáculos mencionados pela maioria dos sujeitos entrevistados, em relação à consideração de questões acerca da natureza do conhecimento científico, é a falta de interesse e a indisciplina dos estudantes.

P1 mencionou as dificuldades de se abordar assuntos relacionados aos modelos na escola estadual onde atua.

\footnotetext{
Hirayama: (...) você faria ((atividade sobre modelos e modelagem)) (...)?

P1: é::.: é difícil trabalhar quando você não tem um... um certo retorno né? aqui ((na ETEC)) até é possível trabalhar mas lá ((na escola estadual)) é difícil... tá? alguns alunos se interessariam... a maioria acho que não

--

Hirayama: (...) o que que é mode.:.:lo... qual a diferença de modelo na química e na física.... você falaria isso para eles?

P1: olha eu tenho fugido um pouquinho... eu tenho fugido dessa parte... né?

Hirayama: por quê? (...)

P1: (...) está muito ruim... é.:.: eu falo para eles "olha eu vim aqui para dar aula... se vocês não me escutarem... é::.: vai ser difícil vocês quererem entender" (...)

Hirayama: (...) a importância de construir modelos que explicam os fenômenos (...) reflita sobre a atividade (...) e comente a frase "uma teoria experimentalmente testada não é a verdade"... é essa discussão $P 1$ você já fez:: em sala?

(...)

P1: não fiz... não tenho rendimento... não tenho rendimento

(...)

P1: (...) porque a hora que eu fizer isso cada um vai virar para o outro e vai ligar o celular vai sair eu vou ficar que nem bobo eu vou ficar gritando eu não faço isso
}

De acordo com o professor, a maioria dos estudantes não se interessariam pelas discussões a serem desenvolvidas. Por isso, disse que não tem incluído frequentemente, em sua prática, questões a respeito do tema.

P1 expressou a mesma opinião em relação à abordagem histórica da tabela periódica. Ele apontou que não "fala muito" sobre esse assunto em função da desatenção dos alunos.

Hirayama: (...) você costuma (...) falar um pouco sobre.: a história da tabela periódica P1: (...) em cada primeiro ano eu devo ter:: três alunos interessados... então... quando eles me deixam falar eu falo o que está aqui ((no caderno da rede estadual))... não falo muito... para não desmerecer Mendeleev (...) fez tanto na vida para desmerecer a desatenção dos $\underline{\text { alunos... não falo }}$

P3 mencionou a falta de disposição dos estudantes em participar das situações didáticas propostas como uma das principais dificuldades para a 
realização de atividades de modelagem e a discussão teórica acerca da elaboração dos modelos atômicos.

P3: (...) aí você diz todos esses fundamentos eles são para alunos... não para
frequentadores de aula entendeu?
Hirayama: entendi
P3: tem que ser aluno... aluno disposto
(...)
P3: é o que a gente mais tem... eles não faltam mas também... eles não participam...
P3: (...) isso aqui é muito legal e quarenta e cinco minutos de aula daria pra aluno que está a
fim de enfrentar esse desafio... a primeira coisa que eles diziam é "eu não sei... como é que
eu vou fazer? você não falou"
---- (...) isso aqui ((discussão sobre a provisoriedade das teorias e modelos)) é para aluno
P3:
ideal... não é para aluno que é real... o aluno real não é isso aqui (...) como é que eu me
estimulo pra uma aula onde nada... onde você percebe gente que quer dormir... gente que
está conversando a aula inteira... gente que não faz... "ah a aula é chata" (...)

P4 apontou problemas de disciplina e o desinteresse pela química ao comentar acerca da possibilidade de se trabalhar com algumas questões acerca dos modelos e modelagem.

Hirayama: (...) retomar a definição de modelos... o motivo pelo qual eles foram desenvolvidos... comentar os diversos tipos de modelo científico né? discutir características dos modelos que os alunos elaboraram (...)

P4: (...) eu tenho três salas de segundo ano talvez uma delas só eu consiga fazer isso... tem uma que só dá problema de disciplina

$----$

P4: eu falei só para você tem... um número restrito de alunos vão mostrar interesse em fazer isso (...) ele só vai tentar fazer se ele achar que ele vai ganhar nota

Hirayama: você acha que é possível discutir com eles o processo de modelagem?

(...)

P4: com alguns... com a minoria... talvez possa possa conseguir (...) fazer uma atividade de fechamento né? e propor para eles mas aí vai ter que valer nota... eu/eu tenho que eu tenho que eu tenho que propor atividade de recuperação para esse bimestre e posso até propor isso aqui (...)

Entretanto, apesar de ter evidenciado, com base em sua experiência, os problemas com os quais poderia se deparar ao incluir determinadas discussões em sua prática, P4, de modo pragmático, procurou refletir acerca dos modos pelos quais conseguiria ter a participação da maioria dos estudantes nas atividades a serem desenvolvidas - como no contexto de uma atividade de recuperação, por exemplo.

No que se refere à abordagem das relações entre a química e a sociedade, P1 apontou que, devido à falta de interesse dos alunos, abordaria algumas questões 
sugeridas durante a entrevista tão somente para "cumprir o conteúdo", caso estivessem presentes no material pedagógico da rede estadual.

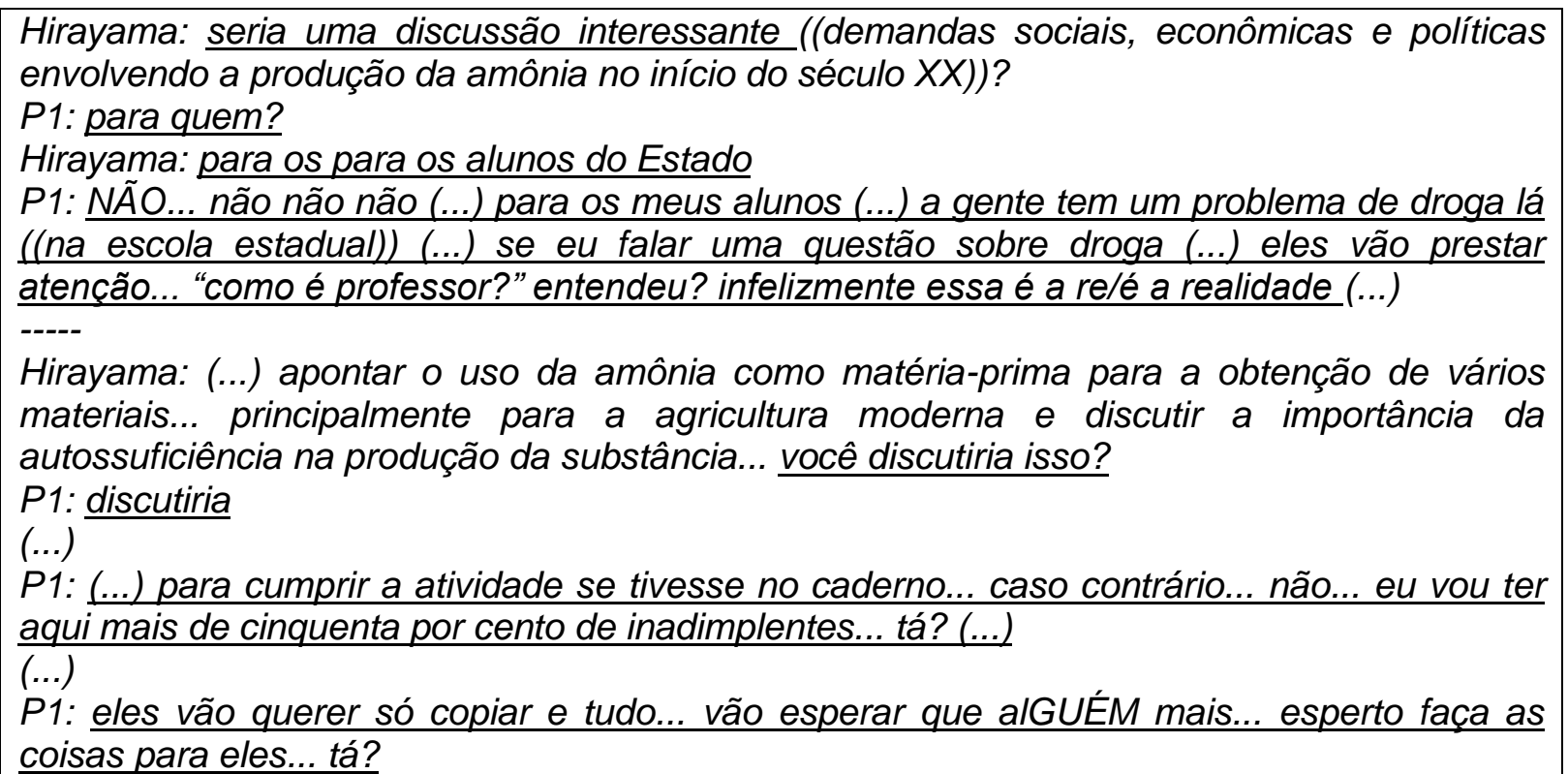

P3, ao opinar sobre as atividades envolvendo a abordagem das interações entre ciência, tecnologia e sociedade, enfatizou que a falta de motivação dos estudantes em participar ativamente na construção do conhecimento e as dificuldades de aprendizagem que possuem, pode, muitas vezes, impossibilitar o trabalho pedagógico sob essa perspectiva.

\footnotetext{
Hirayama: (...) "por que havia um grande interesse da Alemanha na produção da amônia no início século vinte" (...) fornecer aos alunos mais informações sobre o contexto político e econômico da Europa da época...

(...)

Hirayama: isso aqui você trabalharia? você discutiria com a turma?

(...)

P3: sim claro... eles não conseguem discutir (...) você força uma discussão mas não vem (...) eu proporia uma... poderia até depois voltar a discutir isso com eles trazendo... e você descobrir que eles não trazem... dois três trazem e a discussão não vinga (...)

Hirayama: (...) você faria uma atividade dessa ((relação entre a química e a indústria)) com alguma turma que você tem ou não?

(...)

P3: faria... sem dúvida... sei que não tem resultado... mas eu faria... até para dizer "ó... não vai rolar... não vai rolar" eu lembro que ( ) tem uma menina do PIBID veio e disse "nossa como essa escola é interessante os alunos participam"... eu disse "como é J.?" "nossa ( ) você está falando sério?" porque para mim é uma:: é um ou dois alunos que eu consigo... aqueles que não tem medo... de se expor...

(...)

P3: aí quando eu digo "puta eu não consigo dar aula" todos em silêncio... porque pra mim
} 
aula não é isso e eles dizem "nossa mas eles deixam você dar aula" "puta mas não é isso" entende assim?

---

P3: (...) eu acho isso aqui ((relações entre a química e a sociedade)) superinteressante... eu até faria tudo isso (...) eu faço um trabalho que... eu requeira um raciocínio deles (...) eu aponto isso... é igual eu falei... não verticalizo nada disso... eu aponto... eu proponho mas não vem... eu quero que eles tragam... e não acontece (...)

Hirayama: então você acha que é interessante fazer essas discussões?

P3: na verdade ela é imposta na escola né? essa relação... ética social... todas essas implicações ambientais sociais éticas políticas têm que estar presente em todo planejamento... em toda disciplina... mas não faz

Hirayama: e você acha que não faz por quê? não dá::?

P3: por tudo isso que eu já te falei

(...)

P3: a não ser que você dê... e eu discordo...

Hirayama: que você fale?

P3: é... você tem que falar... né? você tem que... você tem que colocar... e... porque podia vir deles né? agora mesmo passei o trabalho para os terceiros anos sobre cinética... eu disse "ó... vocês vão descrever o processo com foco na velocidade" eu eu coloquei alguns temas... conservação de alimentos e coloquei mumificação

P3: (...) um aluno de seis terceiros anos que eu tenho... "essa mumificação... achei legal"... UM aluno... eu já pus de propósito... "vou por esse troço aqui para ver se”... porque podia dizer... "ai mumificação"... algo assim... "ai que horror"... eles copiam... eu explico... leio...

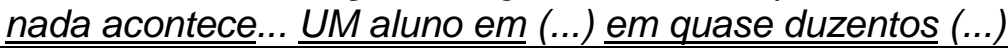

P4 mencionou que, muitas vezes, em função da indisciplina com a qual se depara em algumas de suas turmas, evita realizar atividades experimentais. Ademais, devido à falta de atenção dos estudantes, considera difícil promover, em sala de aula, reflexões a respeito das práticas realizadas.

P4: (...) os alunos do noturno tão tão... tão tão indisciplinados perturbam tanto que eu resolvi nem fazer essa... experiência com eles eu também fiquei muito desanimada esse ano... pegou/eu peguei muito aluno repetente que veio da manhã para noite e só fica... bagunçando na aula e você tem sempre tomando conta da disciplina... aí fiz só o básico não fiz essa experiência

$----$

Hirayama: (...) o professor né? (...) promoveria uma discussão (...) sobre o próprio experimento né? como eles explicaram se eles explicaram da mesma forma que os outros estudantes...

P4: (...) na hora que você vai fazer essa reflexão aí ( ) ocorre muita dispersão né? porque tem aqueles que gostaram fizeram tudo direitinho vão participar e os outros vão ficar desligados conversando sempre acontece isso

(...)

P4: já falei para você alunos de primeiro ano são tão infantis sabe? às vezes você quer chegar num resultado simples e você não consegue

(...)

P4: eles já começam a dispersar muito... aí você já perde a paciência

(...)

Hirayama: entendi

P4: são mui::to infantis aí já começa a dispersar... começa alaí eles de propósito eles começam a falar mais alto... entendeu? eu já fiz eu já testei... aí eles vão falando mais alto 
mais alto para te perturbar aí você faz silêncio ou escreve na lousa (...)

A indisciplina ainda foi citada por P1 como o principal motivo pelo qual ele aborda um vídeo sobre a história da ciência apenas na escola técnica e não com os estudantes da rede estadual que, segundo ele, impedem o desenvolvimento normal das aulas.

Hirayama: (...) tem duas atividades propostas no final... uma... é uma discussão sobre os textos de flogístico né? então o professor trabalha com os alunos... um pequeno texto histórico... você falou que trabalharia um vídeo se não me engano... sobre isso

P1: trabalharia mas não trabalho... não chego a trabalhar o flogístico com eles... só trabalho no técnico

(...)

Hirayama: e... lá ((na escola estadual)) e lá não dá?

P1: não:: dá não dá sem sem condições

(...)

P1: (...) eles não deixam eu falar... eles não deixam a gente ser professor

Além da falta de interesse pelo estudo da química e da indisciplina, os sujeitos entrevistados apontaram as dificuldades de aprendizagem como obstáculo à consideração de assuntos sobre a ciência.

P1 afirmou que não desenvolveria, na escola estadual, discussões acerca das relações entre a ciência e a tecnologia porque, segundo ele, os estudantes estariam abaixo do nível exigido para o ensino médio.

Hirayama: (...) essa discussão ((interdependência entre ciência e tecnologia)) você faria $(\ldots)$ ?

P1: novamen:.:te... na escola estadual não... aqui ((na ETEC)) eu faria... na escola técnica Hirayama: por que lá você não faria?

P1: os alunos estão... abaixo do nível... exigido para o ensino médio (...)

P1 e P3 apontaram que um dos principais problemas com os quais se deparam em sua prática docente é a falta de competência leitora e escritora por parte dos alunos. Os docentes evidenciaram tal questão ao comentar acerca da abordagem das inter-relações entre a química e a sociedade.

Hirayama: você acha que isso ((demandas sociais, econômicas e políticas envolvendo a produção da amônia no início do século XX)) é importante (...) para os alunos? (...)

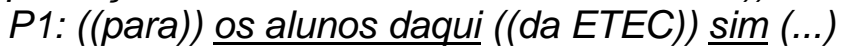

(...)

P1: (...) lá ((na escola estadual)) ele não consegue enxergar ele nem sabe o que é produto acabado... não sabe reagente... o aluno do Estado infelizmente não sa-be ler... ele não sabe 
in-ter-pre-tar (...)

$----$

Hirayama: hoje... você faria uma atividade dessa ((relação entre a química e a indústria)) com alguma turma que você tem ou não?

(...)

P3: que se fosse um/pelo menos um leitor eficiente minimamente - - que eles não são - - aí isso tudo não/também não faz sentido... e se você entra numa discussão até o discurso verbal fica complexo... porque você fala coisas que eles não compreendem a palavra (...). e não é só do termo químico do conceito... às vezes é de/gramatical mesmo

----

P3: (...) porque isso aqui requer uma leitura DE MUNDO uma leitura de cotidiano uma leitura cientifica leitura da língua escrita... leitura da língua falada da oralidade que eles não trazem (...)

Ademais, para eles, o envolvimento dos alunos em discussões que demandam leitura e reflexão - como algumas relacionadas à natureza da ciência e da química - fica comprometido devido às dificuldades dos estudantes em ler, interpretar e escrever textos.

Hirayama: (...) o que é que é mode::Io... você consegue trabalhar essa/essa atividade lá ((na escola estadual))?

P1: não... não consigo... eu precisaria envolver os alunos (...) numa tarefa... teorias... eles não conseguem ter uma concen:.:tração pra ler ( )... alguns não conseguem ler... leitura... leitura eles não conseguem (...)

$---$

Hirayama: (...) essas discussões ((diferenças das leis na química e na física)) (...) são importantes para a formação de um aluno em química?

$P 1$ : se elas são pertinentes né? não eu acho que não

Hirayama: nem interessantes... para os alunos?

P1: por enquanto não (...) por enquanto... nós estamos trabalhando em:: fazer com que o aluno... consiga interpretar o que ele está lendo (...) o aluno do Estado hoje ele não consegue interpretar um tex::to (...) estão saindo com falhas grotescas na len/na língua portuguesa e em matemática... quem dirá então quando ele for interpretar um texto científico (...) jamais eu daria um texto científico para esse aluno interpretar (...)

---

P3: (...) e aí tem uma ((outra)) dificuldade que muitos têm... eles pensam mas não sabem descrever... em pala/em linguagem verbal escriTA... alguns não sabem nem oral... ----

P3: (...) eles têm dificuldade na leitura... essa apreensão compreenSÃO... apreensão... intelecção interpretação do texto você não faz em uma aula de maneira alguma (...) isso ((discussão sobre os fatores que influenciam a elaboração dos modelos)) é para aluno que sabe ler... aí... em vez de você discutir a leitura... você discute o tema... você vai para questão... mas aqui você fica na compreenSÃO... não estou falando interpretação... eles não reconhecem o que está escrito no texto... sair essas questões do texto... é extremamente complexo... é qUAse... pelo menos eu não tenho turmas capazes de fazer isso... turma não... posso ter um aluno ou outro... mas a turma

---

P3: (...) acho bacanérrimo isso aí ((discussão sobre processo de modelagem)) (...) com esses alunos que EU... EU tenho... estou falando dos meus alunos... não consigo... não consegue... não anda... porque eles não conseguem compreender o texto... com-preen-são viu? não estou falando de entendimento 
Essa mesma questão é citada por P4 no que diz respeito à abordagem de aspectos relacionados ao trabalho dos cientistas. No entanto, a professora não colocou as dificuldades dos estudantes como um impedimento à realização das atividades, e sim apontou como elas poderiam ser superadas.

Hirayama: (...) a cooperação e colaboração no desenvolvimento científico? (...) essas discussões elas são são válidas de se fazer com os estudantes?

P4: primeiro você já tem que começar a falar um:: decifrar... você começa a falar esse monte de... de palavras assim eles têm um vocabulário muito restrito né? você já tem que explicar o que significa isso se não eles já ficam achando que você está falando uma coisa muito complicada você tem que ler e explicar o que significa para eles... estou falando para primeiro e segundo ano né? traduzindo a linguagem mais do dia a dia o que significa e o que você quer atingir com eles...(...)

P3 ainda citou que os problemas dos estudantes em expressar, tanto oralmente quanto por escrito, o que pensam e sentem, dificultam a discussão sobre as atividades experimentais, bem como as reflexões sobre elas.

P3: (...) eles não sabem construir um diálogo assim (...) eles não sabem dizer o que estão QUErendo dizer... até dúvida eles não conseguem organizar numa linguagem oral (...) ---

Hirayama: (...) reflexão sobre as atividades realizadas (...) qual sua opinião sobre ela? P3: (...) isso é tudo lindo demais isso é super perfeito eu acho tudo válido tudo real... agora... quando você pergunta a um aluno porquê você fa/fa/pensou assim (...) "por que que/como é que você achou esse resultado?" "ah eu não sei explicar" (...) eles não conseguem descrever

A falta de capacidade de abstração é outro aspecto citado pelos professores ao comentarem acerca das dificuldades envolvendo a consideração de determinadas questões sobre a ciência.

Para P1 e P3, como os estudantes não possuem habilidades espaciais e ainda estão muito ligados à experiência concreta, torna-se difícil desenvolver atividades que requeiram a construção e revisão de modelos.

\footnotetext{
Hirayama: então... qual seria sua opinião sobre os alunos elaborarem modelos? (...)

P1: não

(...)

P1: quando eu falo do fulereno (...) entrou de um lado e saiu do outro... se eu falar o modelo do grafite... do diamante tudo... não vai... o tetraedro eles não conseguem enxergar 0 espaço

Hirayama: você acha importante que eles façam ((elaborem os próprios modelos))?
} 
P3: ah:.: sem dúvida... construção né?... lógico que é... e a ideia do... eu acho que... agora eu sei porque eu evito fazer... porque é/tem uma discussão do concreto que eles (...) parece que eles precisam ver... é quase a mesma coisa quando você apresenta átomo para oitava série (...) "quem já viu? como é? alguém já viu?" eles querem o concreto ainda querem (...)

P3 e P4 mencionaram também o pouco desenvolvimento da capacidade de abstração como um dos principais desafios para a abordagem de modelos e a realização de discussões filosóficas envolvendo o tema reducionismo no estudo da química da água.

\begin{abstract}
P3: (...) primeiro tem que entender que nem todos que chegam no primeiro ano sabem 0 que é $\mathrm{H}_{2} \mathrm{O}$ viu? MESMO

(...)

P3: (...) $\underline{H}_{2} \mathrm{O}$... eu coloquei isso aqui no quadro... "o que é isso? é áqua?" "é"... "é áqua?" "não... não é?" eles não conseguem... é a questão da abstração... aí é outro ponto... tratar esse tema é pensar que eles conseguem abstrair... né? (...) símbolos signos... para eles é uma dificuldade... eles não têm esse domínio... eu acho... primeiro por falta de abstração(...) $---$

P4: para eles é uma abstração enorme eles não conseguem entender ((questão dos modelos de ligação))... o máximo que você consegue fazer eles entenderem é que os átomos estão ligados... as ligações... como se fosse/estivesse explicando com o Dalton "aqui está combinado assim aqui está separado assim"... para eles é muito abstrato isso ----

Hirayama: (...) na atividade cinco e seis aqui eles testam o modelo né? que eles tentaram elaborar para explicar alguns:: algumas:: éh::: dar alguns dados empíricos né? como por exemplo elevar a temperatura de fusão e depois tentam montar...

(...)

P4: você consegue entender... interpretação de tabela se tem uma tabela com dados vamos... vamos classificar vamos separar vamos agrupar... isso eles conseguem fazer...

Hirayama: e você acha que é importante eles tentarem fazer isso?

P4: só que eles não conseguem entender o porquê porque é uma coisa muito abstrata eles não conseguem entender a diferença exatamente de uma ligação iônica com uma ligação... ----

P4: (...) o arranjo da/da/das pontes de hidrogênio em estado líquido o estado sólido (...). eu não sei até que ponto eles rece/na cabecinha deles eles fazem a relação não (...) não vão che/não vão chegar num:: num nível microscópico... você queria que a explicação fosse em vários níveis para ele entender a nível microscópico né? seria o ideal né? (...) eles olham assim "ah é"... mas talvez eles fiquem pensando que a água lá tá... que o:.:: palito tá boiando na água talvez eles fiquem pensando que a molécula de água é grande (...)
\end{abstract}

P4 relacionou ainda a falta de capacidade de abstração dos estudantes com problemas de análise e a defasagem em matemática.

P4: (...) o pessoal é muito ruim com o desenvolvimento de... de de análise de tirar conclusão entendeu? eu acho que tinha que ter um treinamento mais intenso tinha que ter... $\underline{a}$ matemática tinha que ser... tem que ter uma maior cobrança porque você vai treinando de resolver uma equação e chegar no resultado e tira uma conclusão... aí você vai aprendendo uma sequência lógica de pensar que você pode aplicar em qualquer outra coisa... 
P1 apontou a dificuldade dos estudantes em realizar contas e cálculos como um dos motivos pelos quais considera mais relevante abordar os aspectos qualitativos relacionados ao tema equilíbrio químico.

Hirayama: por que... você acha que é mais importante ((abordar mais os aspectos qualitativos relativos a equilíbrio químico))?

P1: porque é mais fácil... é:: não tem tempo... e outra eu teria que.: lançar mão da matemática e nem sempre todos estão preparados para a matemática (...)

P2 e P5 também mencionaram algumas dificuldades em relação ao trabalho com estudantes em suas escolas. Entretanto, ao contrário dos outros docentes, suas falas durante as entrevistas não sugerem uma influência significativa de tais fatores em suas práticas e concepções. P5, por exemplo, defendeu que a leitura de artigos adaptados ao ensino médio visando fomentar a discussão sobre a experimentação na química poderia contribuir para o desenvolvimento da capacidade leitora dos estudantes.

Hirayama: (...) o professor discutiria né? no caso as funções dos experimentos na química (...) as principais atividades dos químicos atualmente (...)

(...)

P5: é eu daria normal lógico que daria eu acho MUito legal fazer isso é muito bom para o aluno ele vai ter... éh:: ele ele vai primeiro vai ajudar na leitura do nosso aluno do Estado porque é triste...

Hirayama: tem dificuldade?

P5: mui::ta dificuldade em leitura... éh:: então já seria uma aula já para leitu::ra para compreensão de texto que também é outra dificuldade nossos alunos saem daqui... com essa deficiência de leitura $E$ interpretação não só devido à química ou a ciência entendeu? é... é muito bom (...)

Ainda que a docente não tenha apontado a relevância da atividade em função das discussões que enseja, mas apenas em relação ao uso de textos, ela não apresentou os problemas dos estudantes como um empecilho para a utilização de situações de ensino que exigem leitura, interpretação e reflexão.

3.2.2.2. Falta de tempo 
O pequeno número de aulas de química semanais foi mencionado por todos os docentes como um dos obstáculos à consideração de alguns aspectos a respeito da ciência, discutidos no decorrer das entrevistas.

P2 apontou que abordaria a evolução dos modelos atômicos históricos por meio de um breve vídeo de sete minutos. Embora tenha mencionado a importância de se compreender tal processo como uma construção humana, a docente apontou a economia de tempo como o principal motivo pelo qual optaria por essa estratégia.

P2: (...) aqui tem um texto que situa... né? a parte.: histórica... né? éh... "ideias de Thomson sobre o átomo parte um" (...) sabe o que eu (...) eu mataria toda essa questão aqui com um vídeo do youtube

Hirayama: por que você faria dessa forma?

(...)

P2: é uma coisa bem rápida e mUlto didático né? então eu usaria esse mecanismo... eu acho que seria... bem... bem melhor (...)

P2: (...) fica mais... mais ágil entendeu? acho que pega mais... e eu economizo tempo (...) ---

P2: (...) eu usaria um vídeo de youtube e tal... até para... para economizar tempo porque TEMpo a gente não tem... mas se o menino achar que isso é o que ele vai fazer na vida... ele tem que entender que isso não é como um aplicativo de um celular de uma hora pra outra... precisa de dedicação... né? então é fundamental pra ele entender que é uma construcão huMANA.

P1 e P4, por sua vez, também mencionaram que o número de aulas semanais da disciplina de química é insuficiente para discutir acerca de aspectos relacionados aos modelos atômicos históricos.

\footnotetext{
Hirayama: quando você trabalha com::com::o caderno você costuma utilizar essas essas atividades ((sobre modelos de Bohr e Rutherford)) ou não P1?

$P 1$ : quando dá tempo eu costumo quando não dá não... utilizo

(...)

Hirayama: (...) essa abordagem você não acha importante para o estudante do ensino:: médio?

$P 1:$ não... não acho

Hirayama: por quê?

P1: porque eles não têm condições de acompanhar

Hirayama: e se eles tivessem?

P1: poderia até fazer... mas novamente aqueles é... se eu tivesse mais aulas é... daria para trabalhar... com duas aulas não é possível

Hirayama: (...) os diversos modelos atômicos em discussão na época?...essas discussões... você faria com eles? você acha que ela é importante (...)?

P4: (...) você não tem tempo para isso para você fazer uma coisa desse nível você teria que ter mais aulas

$(\ldots)$

P4: você não tem... você só tem duas aulas por semana...
} 
P2 também mencionou que, em função da falta de tempo, não costuma incluir assuntos da história da ciência no ensino, apesar de ter citado que tal perspectiva Ihe agrada e é importante para a formação dos estudantes.

Hirayama: e você costuma utilizar essas atividades assim no:: trabalhar com elas no ensino médio?

P2: eu gosto... não costumo usar (...) por que que eu não costumo usar? (...) o tempo é muito curto... então eu me limito bastante assim

Ademais, embora tenha atribuído relevância às atividades de modelagem e descrito uma prática, no ensino fundamental, em que os estudantes são incentivados a elaborar seus próprios modelos, P2 novamente mencionou a falta de tempo como obstáculo para a realização dessas atividades no ensino médio. A docente apontou que, nesse nível de escolaridade, seu principal foco é trabalhar com listas de exercícios.

Hirayama: (...) você acha interessante fazer ((alunos elaborarem os próprios modelos))? no médio?

P2: no médio eu acho interessante só que eu esbarro no tempo de duas horas... de... na verdade cem minutos né? ( ) esbarro na questão DO tempo... duas aulas por semana... né?

P2: (...) eu não vou propor para ele ((o aluno)) fazer... o modelo... eu faria entendeu? (...)

Hirayama: e o fato de você não... não... não usar o modelo dELE tem a ver com... com qual questão?

P2: no meu caso tem a ver com o tempo só... né? apesar que eu acho válido o modelo DEle ----

P2: (...) e assim... esses modelos eu sempre uso com os meninos do... do fundamental né? assim que eles criem... criem modelos

Hirayama: entendi

P2: do médio - - de verdade Marcos - - assim ... eu fico mais... presa assim... eu corro mais com eles talvez pelo... pela falta de tempo eu fico mais presa aqui ó... na tarefa na lista de exercícios

As últimas falas no trecho acima sugerem uma relação entre o fator falta de tempo e os objetivos e papel docente. Como foi discutido anteriormente, uma das principais finalidades de P2 no ensino médio é a preparação para os exames vestibulares e o ENEM. Desse modo, em função da escassez de tempo, a professora prefere trabalhar com atividades que favoreçam a consecução desse objetivo. Já no ensino fundamental, visto que não tem um compromisso premente 
com as provas de seleção, não considera perda de tempo a realização de atividades que permitam aos estudantes elaborar e explicar seus próprios modelos.

Do mesmo modo que P2, P5 fez considerações a respeito da falta de tempo para se trabalhar com atividades de modelagem.

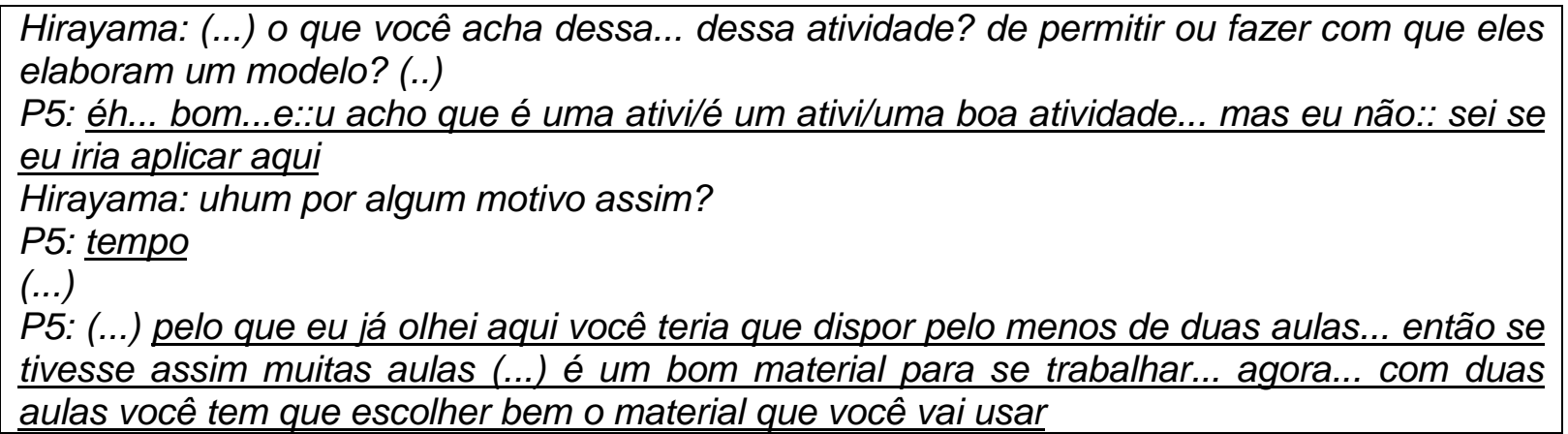

P3 e P4 também apontaram a falta de tempo como empecilho para a realização de discussões relativas à experimentação. $\mathrm{P} 1$, por sua vez, mencionou tal fator ao justificar por qual razão quase não desenvolve práticas experimentais na escola estadual em que trabalha.

P1: (...) eu não tenho condiç̃es de fazer a parte experimental... no Estado... no Estado eu...
e também não quero (...) não tenho tempo para isso
---.
Hirayama: (...) o que você acha dessa proposta? os estudantes... comunicam as suas ideias
para os colegas... né? sobre... o experimento... eles elaboram uma conclusão sobre o
fenômeno observado... justificando as ideias (...) você acha que é possí/você trabalharia
nesse sentido?
P3: (...) essa discussão do resultado dos grupos... isso é de/isso... é super ideal é super
bacana super inteligente super interessante... mas não há tempo de fazer isso
(...)
Hirayama: mas você considera essa discussão interessante?
P3: ah eu acho importantíssimo... essa discussão toda do que fez... agora não dá tempo de
fazer isso... não dá tempo de fazer isso...com qualquer trabalho não dá tempo de fazer isso
não é só experimental não até um texto... posso trabalhar um texto
----
Hirayama: (...) discute essas opiniões essa essa dos diferentes alunos depois por meio de
perguntas leva os estudantes de testarem né? suas concepções ele volta...
P4: quer dizer isso aqui isso ia gastar no mínimo gastar duas aulas... ia gastar uma aula
para eles fazerem medirem aí vocêt tem que deixar sair e voltar e depois você vai ter que ir
retomando (...)
(...)
P4: (...) vai gastar duas aulas com isso no mínimo né? outra coisa que... que limita a gente
no número da gente de aula prática é que você tem um monte de conteúdo e duas aulas por
semana... aí você já vê que vai fazer uma experiência disso você vai gastar uma semana...
primeiro você vai ter que preparar você vai ter que preparar... eles vão gastar uma semana
para fazer e depois eles ainda vão ter que entregar um relatório aí já... se você for comentar
de novo já vão ser três aulas aí você tá perdendo muito tempo com uma coisa só


Em relação à experimentação, o pequeno número de aulas mencionado pelos docentes está associado a outro fator: a falta de condições.

\subsubsection{Falta de condições}

Esse fator foi identificado exclusivamente em relação aos comentários dos sujeitos entrevistados sobre a Experimentação.

Um dos principais motivos para $\mathrm{P} 1$ raramente desenvolver atividades experimentais na escola estadual onde atua é a falta de um laboratório. Ainda assim, P1 mencionou a importância das atividades práticas e descreveu alguns experimentos que desenvolveu com os estudantes.

Conforme as falas a seguir evidenciam, P3 e P4 apontaram a falta de condições materiais e de ajuda como dificuldades à realização de atividades experimentais.

\footnotetext{
Hirayama: qual motivo principal assim de... de você não fazer ((atividades experimentais))? P3: primeiro condições de trabalho que não há... um espaço adequado segundo... não há TEMpo... porque você é o professor você é o... o auxiliar de laboratório... porque você tem duas aulas... você tem que preparar a aula prática... che-gar... dar aula realizar aula prática... la-var e guardar os materiais... e outra né? sem condição aqui tem uma pia uma pia rasa... bom... não... inferno... vira inferno ----

P3: (...) "ah você não acha esse experimento importante?" "acho".. mas eu não vou brigar com o sistema (...) me deem condições que eu faço (...) eu não vou fazer em canequinha de não sei o quê... em copinho plástico de não sei das quantas (...) me dá condições que eu crio melhor (...)

(...)

P3: você tem que dar aula experimental mas a escola não te dá estrutura para isso... e não é só material não (...) porque se eu atrasar para subir... né? se eu fizer na sala... molhou... aí eu tenho que descer pedir alguém para limpar... perco aula...aí os alu/vira um inferno... então... você não tem (...) as condições mínimas né?

$---$

P4: (...) experimentação é complicado porque tem um laboratório antigo da escola (...) foi feita uma reforma na bancada (...) os armários de guardar os materiais eram de madeira antiga aí jogou tudo fora... aí colocou:: tipo assim estante comum lá (...) o que sobrou de material o que não quebrou de vidraria está tudo bagunçado cheio de poeira e aí a gente vai lá só na emergência se for fazer alguma coisa correndo (...) tem poucos reagentes... alguns que a gente não achava que o rótulo nem dá para ler alguns que a gente achava que não tinha condição de uso (...)

P4: (...) então tem que ter colaboração ninguém toma conta... pega vai lá... não sei o quê e ninguém vai ver o que aconteceu depois some as coisas... e a gente/eu tenho... muito receio que... os alunos são muitos alunos... e a gente sozinha para tomar conta... sempre faz alguma coisa errada
} 
Hirayama: e:.: o que seria uma boa aula experimental para você $P 4$ assim? que uma aula experimental... ideal?

P4: ideal é que tivesse alguém para ajudar você... entendeu? que você... porque você tem que chegar antes e você não ganha para isso... não é? você não ganha nem antes nem depois você tem que preparar antes depois você tem que deixar em ordem... muitas vezes você tem que trazer os materiais da sua casa... entendeu? um apoio

$---$

P4: (...) é superimportante, mas a gente fica a gente é limitado por várias coisas que eu já comentei aqui tempo... falta de alguém que nos auxilie entendeu? aí você... você tem horário para entrar sair dar sequência... você chega atrasado... cinco minutos a outra sala pega e já sai tudo está no corredor bagunçando... já perturba as salas vizinhas... você tem que... limpar organizar... muitas vezes trazer de casa... você está sempre sozinha... toda vez que tem estagiário comigo eu consigo... éh:: aproveitar a presenca deles e fazer

P3 indicou que os problemas que encontra em sua escola o impedem de realizar atividades experimentais. Já P4 comentou que, devido a essas dificuldades, realiza apenas demonstrações com os estudantes, principalmente quando há estagiários para ajudá-la.

Para a docente P5, a falta de materiais, de reagentes e de um ajudante também dificulta a realização dos experimentos. Entretanto, esses problemas não a impedem de desenvolver, com os estudantes, práticas experimentais, já que, para ela, essas são uma das principais formas de suscitar o interesse dos estudantes pela matéria e também em função de sua escola ter um espaço relativamente adequado para a realização dessas atividades.

P5: eu não tenho quem me ajude por exemplo... esse aí já é o principal fator... e também não tinha muito material... agora o diretor que nós temos agora... não sei... chegou ele comprou tudo que eu pedi... chegou ontem até fiquei até contente (...)

$(\ldots)$

P5: (...) eu quero fazer um experimento mas tem que preparar o laboratório? que horas? (...)

P5: eu não tenho esse horário... então eu fico assim por exemplo... eu escrevo eu passo eu coloco uma coisa na lousa e aí eu venho correndo aqui arrumando as bancadas... os alunos ajudam bastante na limpeza por exemplo eles nunca deixam nada em cima nada su::jo... eles limpam ... isso já é uma combinação agora não tenho quem lave então todo mundo vai lavar... eu vou guardar depois né? mas não tem dificuldade nisso... (...)

----

P5: ideal é ter... eles terem todo... todo material de segurança todo equipamento... tudo que eu quiser... todos os reagentes necessários para aquele experimento (...)

3.2.2.4. Demandas em relação ao ensino de química 
No que tange a P3, a compreensão de quais conteúdos fazem parte da disciplina de química está relacionada com suas dúvidas acerca da contribuição dos conhecimentos químicos disciplinares na vida dos estudantes.

P3: (...) eu tenho dúvidas... o conteúdo não é importante? mas as nossas seleções... para você entrar na USP no mestrado foi também conteúdo você também foi conteúdo... qualquer concurso é conteúdo... você está tirando deles a oportunidade... de entrar nas universidades melhores sim porque elas selecionam por conteúdo... aí eu fico nessa eterna dúvida (...) eu fico numa coisa... eu/eu/eu realmente acho tudo isso ((estabelecer relações entre química, tecnologia e sociedade)) mais importante do que o conteúdo mas eu fico me perguntando (...)

Hirayama: entendi

P3: estou interrompendo o/o processo de alguns entendeu?

As falas acima evidenciam que a preocupação de P3 com uma possível exclusão do que ele considera como conteúdos próprios do ensino de química, ao se trabalhar com questões contextuais, está relacionada com as demandas sociais em relação à educação em química. Apesar de considerar a abordagem das relações entre química e sociedade relevante para o desenvolvimento da autonomia intelectual dos estudantes, ele arrazoou que nos exames vestibulares, e até mesmo na seleção de candidatos em empresas, o que é cobrado e exigido deles são os conteúdos factuais e conceituais da disciplina de química, ou seja, as fórmulas, os conceitos, as equações, etc. (Zabala, 1998).

Zabala (1998) aponta que, se a função social do ensino fica restrita à função seletiva e propedêutica, os conteúdos conceituais tornam-se a principal fonte epistemológica. No entanto, se a referência precípua é a formação integral dos estudantes, torna-se fundamental o ensino integrado dos diferentes tipos de conteúdos: factuais, conceituais, procedimentais e atitudinais.

No que concerne a essa discussão, King (2012) considera que a aprendizagem de química sob uma perspectiva contextual contribui para a compreensão dos conceitos científicos específicos. Ademais, Talanquer (2013), com base em discussões da filosofia da química, defende que uma educação química mais autêntica, significativa e relevante, envolve, dentre outros aspectos,

eliminar a separação artificial entre o substantivo, o sintático e os aspectos éticos da disciplina; entre a química como conteúdo, química como processo (ambos como investigação e implementação, como exploração e transformação e como empreendimento científico e tecnológico) e química como agente social (p.1765). 
De acordo com essa perspectiva, os conteúdos da disciplina de química abrangeriam não apenas as leis, teorias e modelos químicos, mas também os meios pelos quais eles foram obtidos, bem como as relações recíprocas entre química e sociedade.

\subsubsection{Materiais didáticos}

Um dos fatores que afetam a prática da docente P5 em relação à abordagem das relações entre química e sociedade é o material didático. P5 apontou que, antes de trabalhar com o material didático da rede pública estadual de São Paulo, não costumava discutir com os estudantes o contexto social, político e econômico que influenciou o desenvolvimento do processo Haber-Bosch de obtenção da amônia.

Hirayama: (...) fornecer aos alunos mais informações sobre o contexto político... econômico da Europa e discutir as demandas envolvidas na obtenção... então isso você trabalha com eles?

P5: eu trabalho com eles porque...

Hirayama: tanto aqui quanto lá no...?

(...)

P5: até na ETEC eu trabalho assim... essa... quando eu começo equilíbrio...

(...)

P5: eu começo equilíbrio falando... nos três... antes eu... éh:: e eu só fui conhecer esse.: método aqui depois da:.:. que chegou a apostila... porque eu não trabalhava assim não(...)

Portanto, são múltiplas e complexas as questões que podem influenciar os professores a inserir ou não, em suas práticas, assuntos acerca da natureza da ciência e da química. O Quadro-resumo 09 apresenta uma síntese de como tais fatores podem afetar o trabalho e a percepção dos sujeitos entrevistados no que se refere a cada aspecto discutido no decorrer das entrevistas. 


\begin{tabular}{|c|c|c|c|c|c|}
\hline \multirow[t]{2}{*}{ Sujeitos } & \multicolumn{5}{|c|}{ Fatores que afetam a concepção } \\
\hline & $\begin{array}{l}\text { Relações com a } \\
\text { sociedade }\end{array}$ & Modelos e Modelagem & Experimentação & $\begin{array}{l}\text { Desenvolvimento } \\
\text { histórico }\end{array}$ & Reducionismo \\
\hline P1 & 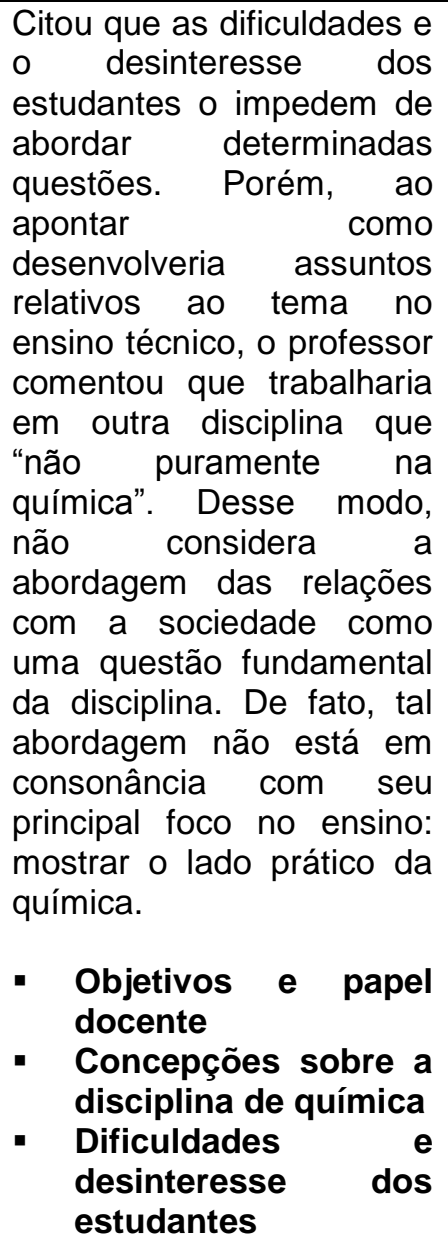 & 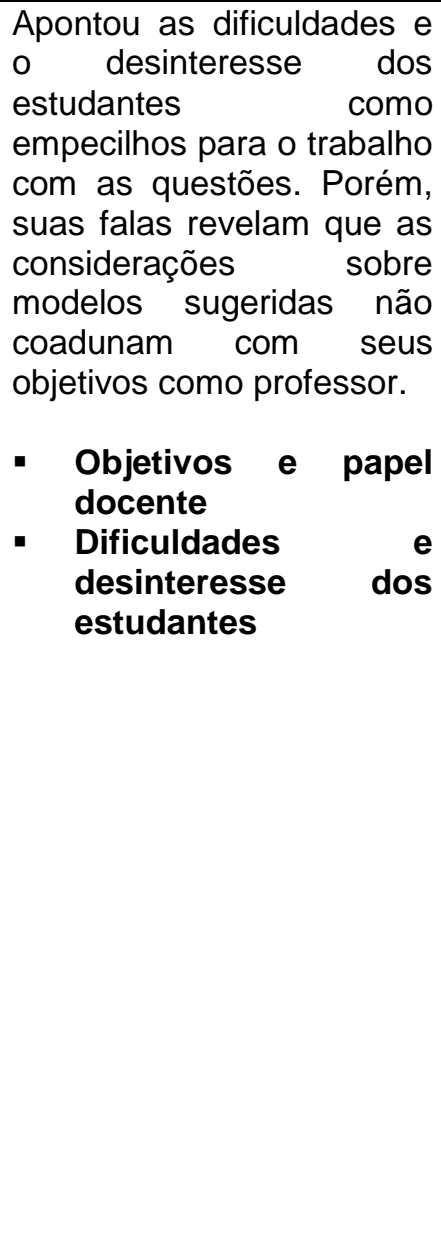 & 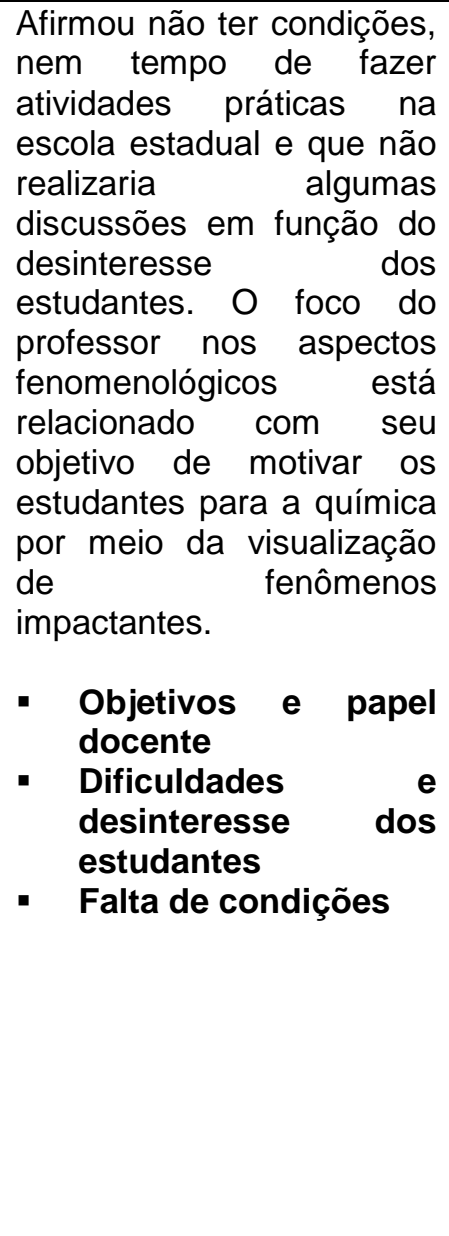 & $\begin{array}{l}\text { Apontou, como principais } \\
\text { obstáculos para a a } \\
\text { discussão de algumas } \\
\text { questões acerca da ciência } \\
\text { por meio da abordagem } \\
\text { histórica, o pouco número } \\
\text { de aulas semanais, assim } \\
\text { como a dificuldade e o } \\
\text { desinteresse Entretanto, } \\
\text { estudantes. Entreta do } \\
\text { mencionou que algumas } \\
\text { discussões estariam } \\
\text { tirando o foco da química } \\
\text { que é "mostrar o cotidiano } \\
\text { para os estudantes". } \\
\text { Ademais, ao comentar } \\
\text { como desenvolveria } \\
\text { algumas atividades, } \\
\text { revelou seu foco nas } \\
\text { "questões práticas". } \\
\text { - Objetivos e papel } \\
\text { docente } \\
\text { - Dificuldades } \\
\text { desinteresse dos } \\
\text { estudantes } \\
\text { - Falta de tempo }\end{array}$ & 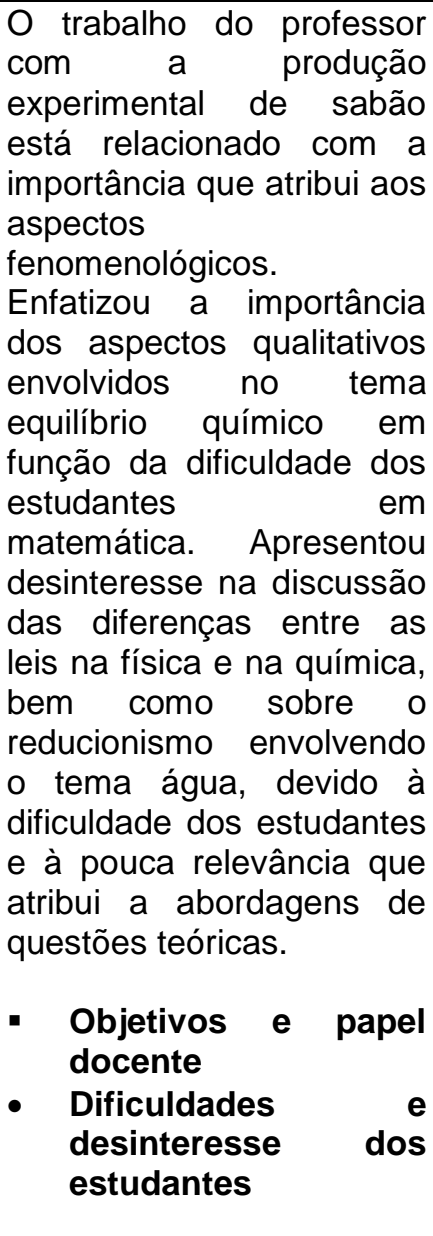 \\
\hline
\end{tabular}




\begin{tabular}{|c|c|c|c|c|c|}
\hline & $\begin{array}{l}\text { Relações com a } \\
\text { sociedade }\end{array}$ & Modelos e Modelagem & Experimentação & $\begin{array}{c}\text { Desenvolvimento } \\
\text { histórico }\end{array}$ & Reducionismo \\
\hline P2 & $\begin{array}{l}\text { Sua concepção acerca da } \\
\text { importância da inserção de } \\
\text { questões sociais, } \\
\text { econômicas, políticas e } \\
\text { ambientais no ensino de } \\
\text { química é influenciada pela } \\
\text { visão a respeito das } \\
\text { finalidades educacionais: } \\
\text { formação cidadã e a } \\
\text { preparação dos estudantes } \\
\text { para os exames } \\
\text { vestibulares e o ENEM. } \\
\text { Apesar disso, a professora } \\
\text { citou que, muitas vezes, } \\
\text { não aborda algumas } \\
\text { questões, pois precisaria } \\
\text { da ajuda de professores de } \\
\text { outras áreas. Desse modo, } \\
\text { a falta de conhecimentos } \\
\text { parece impedir a docente } \\
\text { de incluir determinadas } \\
\text { questões em sua prática. } \\
\text { Objetivos e papel } \\
\text { docente } \\
\text { - Conhecimentos do } \\
\text { professor }\end{array}$ & 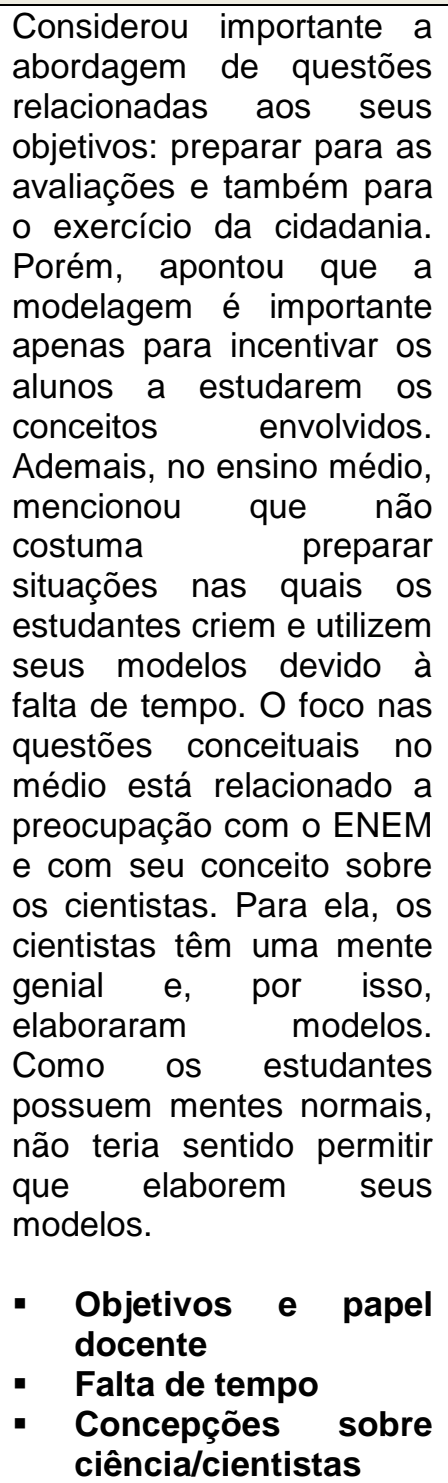 & $\begin{array}{l}\text { Apontou a falta de tempo e } \\
\text { a dificuldade dos } \\
\text { estudantes como } \\
\text { empecilho para a } \\
\text { realização } \\
\text { determinadas discussões. } \\
\text { Contudo, em relação a } \\
\text { algumas questões, é } \\
\text { influenciada por sua } \\
\text { preocupação com os } \\
\text { exames vestibulares e o } \\
\text { ENEM. } \\
\text { - Objetivos e papel } \\
\text { docente } \\
\text { Falta de tempo }\end{array}$ & $\begin{array}{l}\text { Para ela - visto que os } \\
\text { conhecimentos científicos } \\
\text { melhoram no decorrer da } \\
\text { história em função do } \\
\text { trabalho de pessoas que } \\
\text { contribuíram para o bem } \\
\text { da humanidade e } \\
\text { trabalharam com afinco até } \\
\text { se tornarem geniais - a } \\
\text { HC é fundamental para } \\
\text { valorizar os cientistas e } \\
\text { para que sua história sirva } \\
\text { de exemplo para os } \\
\text { estudantes. Segundo ela, } \\
\text { esse é o papel da HC na } \\
\text { promoção da cidadania. } \\
\text { Ademais, também apontou } \\
\text { que compreender que os } \\
\text { modelos não são verdade } \\
\text { absoluta contribui para a } \\
\text { formação do cidadão, pois } \\
\text { estimula a criticidade dos } \\
\text { estudantes. No entanto, } \\
\text { aponta que utilizaria um } \\
\text { vídeo para tratar tal } \\
\text { questão, em função do } \\
\text { pouco tempo que possui. } \\
\text { Objetivos e papel } \\
\text { docente } \\
\text { - Concepções sobre } \\
\text { ciência/cientistas } \\
\text { Falta de tempo }\end{array}$ & $\begin{array}{l}\text { Apontou a relevância de } \\
\text { trabalhar com aspectos } \\
\text { qualitativos envolvidos no } \\
\text { equilíbrio químico, pois, } \\
\text { para ela, os aspectos } \\
\text { quantitativos não } \\
\text { constituem o cerne da } \\
\text { química. No entanto, um } \\
\text { dos aspectos que } \\
\text { influencia a docente é o } \\
\text { gosto pessoal. Ao } \\
\text { comentar a importância de } \\
\text { os estudantes } \\
\text { compreenderem as á } \\
\text { propriedades da água por } \\
\text { meio do entendimento de } \\
\text { como as partículas } \\
\text { interagem, ela expressou } \\
\text { que acha importante } \\
\text { porque é um assunto do } \\
\text { qual gosta, e que isso } \\
\text { influencia a escolha de } \\
\text { atividades. } \\
\text { Concepções sobre a } \\
\text { disciplina de química } \\
\text { Preferências } \\
\text { pessoais }\end{array}$ \\
\hline
\end{tabular}




\begin{tabular}{|c|c|c|c|c|c|}
\hline & $\begin{array}{l}\text { Relações com a } \\
\text { sociedade }\end{array}$ & Modelos e Modelagem & Experimentação & $\begin{array}{l}\text { Desenvolvimento } \\
\text { histórico }\end{array}$ & Reducionismo \\
\hline P3 & 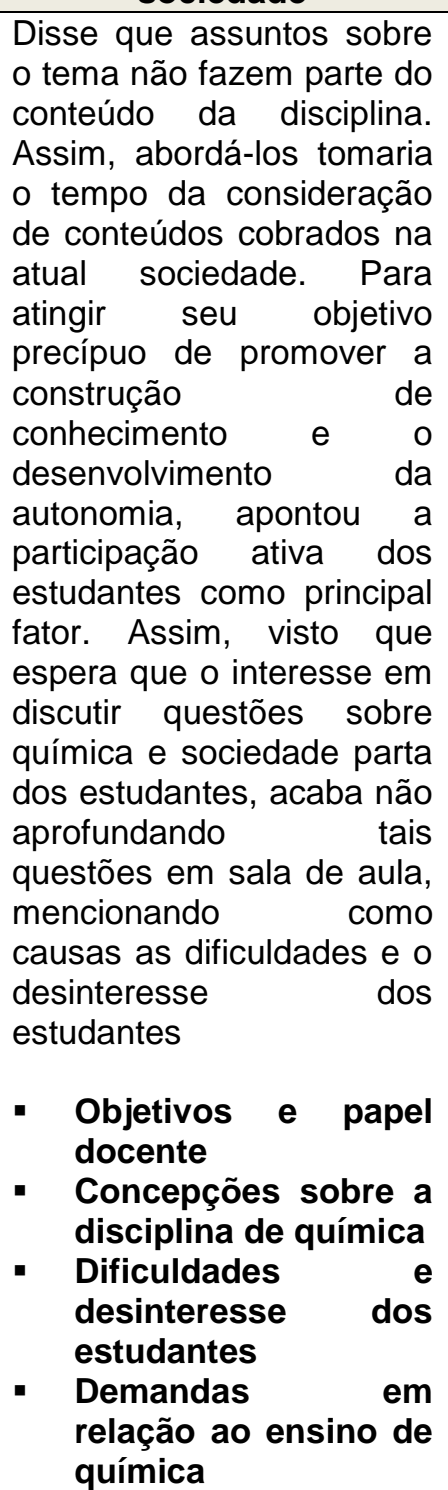 & 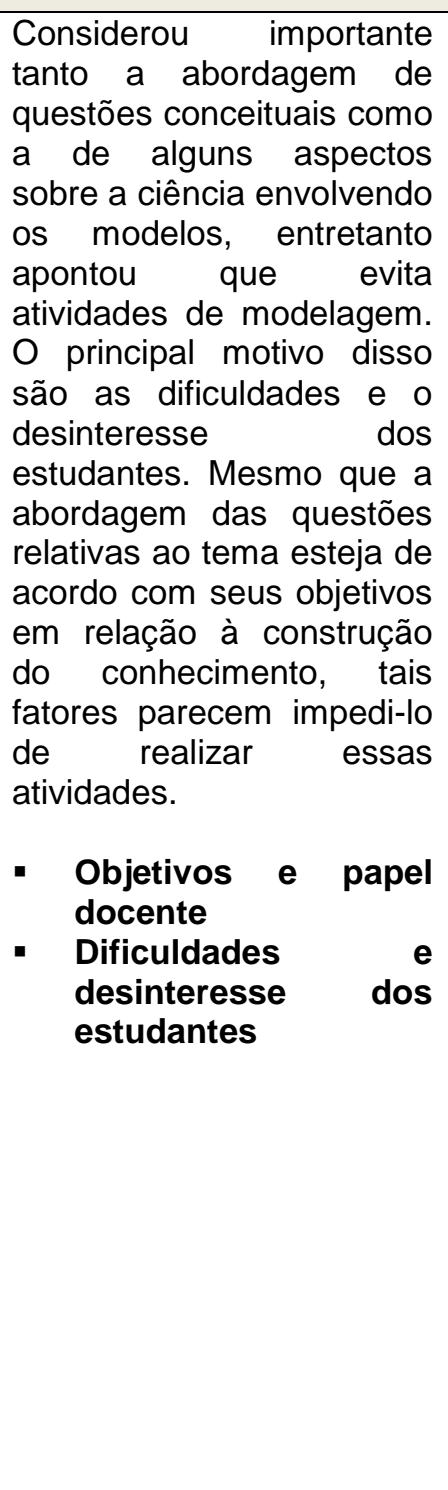 & $\begin{array}{l}\text { O fato de o docente não } \\
\text { realizar atividades } \\
\text { experimentais está } \\
\text { relacionado com a falta de } \\
\text { condições: lugar } \\
\text { adequado, falta de } \\
\text { materiais e falta de auxílio, } \\
\text { além do pequeno número } \\
\text { de aulas e da dificuldade } \\
\text { dos estudantes. } \\
\text { - Dificuldades } \\
\text { desinteresse dos } \\
\text { estudantes } \\
\text { - Falta de tempo } \\
\text { - Falta de condições }\end{array}$ & 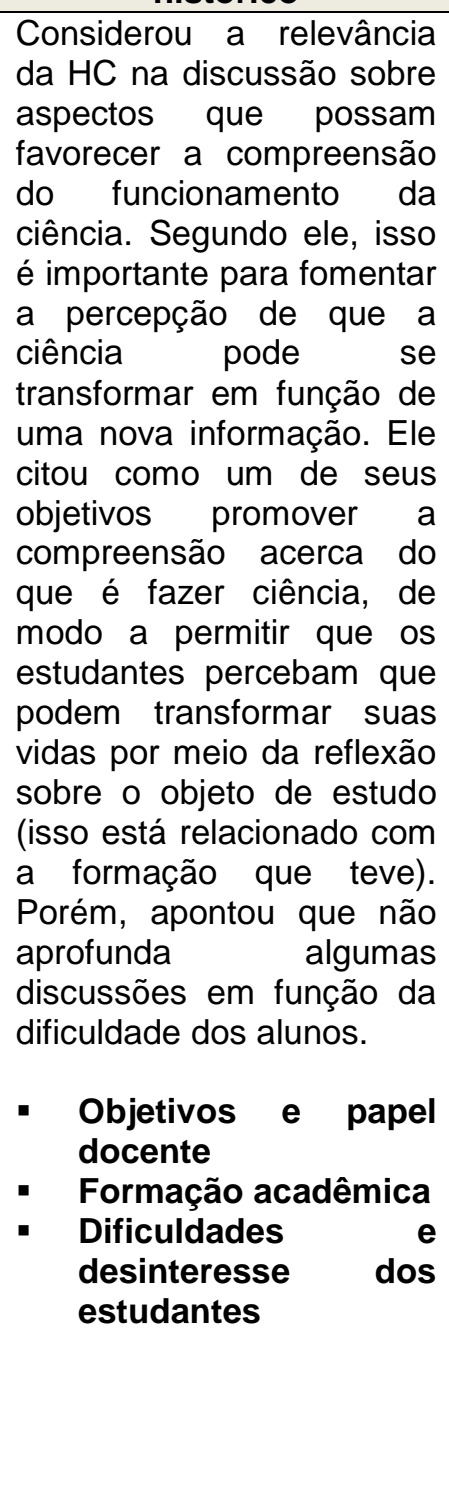 & 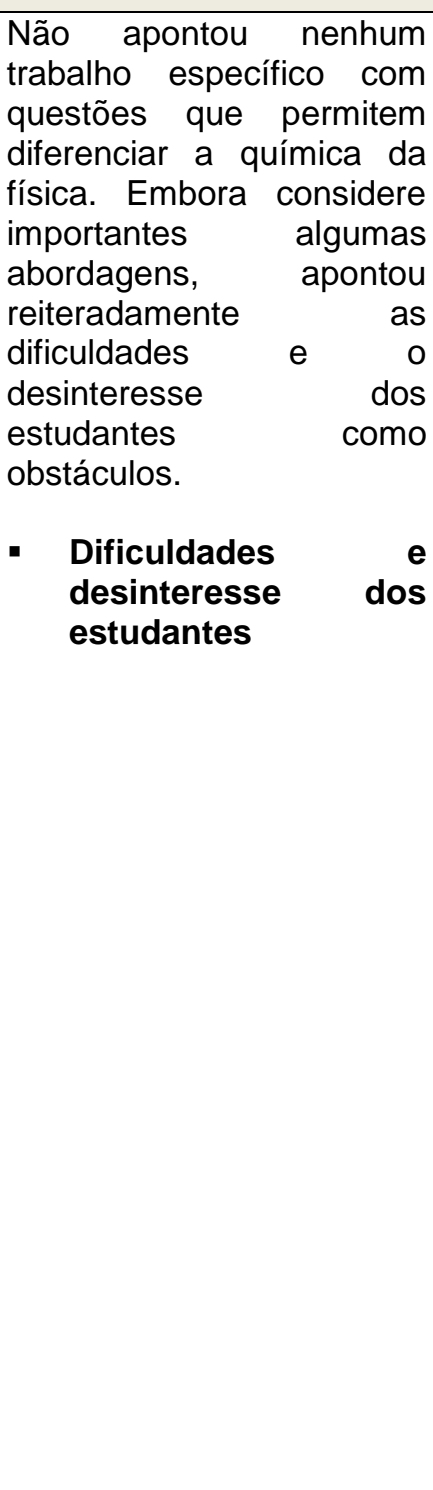 \\
\hline
\end{tabular}




\begin{tabular}{|c|c|c|c|c|c|}
\hline & $\begin{array}{l}\text { Relações com a } \\
\text { sociedade }\end{array}$ & Modelos e Modelagem & Experimentação & $\begin{array}{c}\text { Desenvolvimento } \\
\text { histórico }\end{array}$ & Reducionismo \\
\hline $\mathrm{P} 4$ & $\begin{array}{l}\text { Não ficou explícito quais } \\
\text { fatores influenciam a } \\
\text { concepção da professora } \\
\text { no que tange a esse tema. } \\
\text { No entanto, ela parece } \\
\text { orientar suas ações a partir } \\
\text { de uma perspectiva mais } \\
\text { pragmática. } \\
\text { preocupações Suas } \\
\text { concentram no material } \\
\text { didático e em como } \\
\text { poderia desenvolver as } \\
\text { atividades. }\end{array}$ & 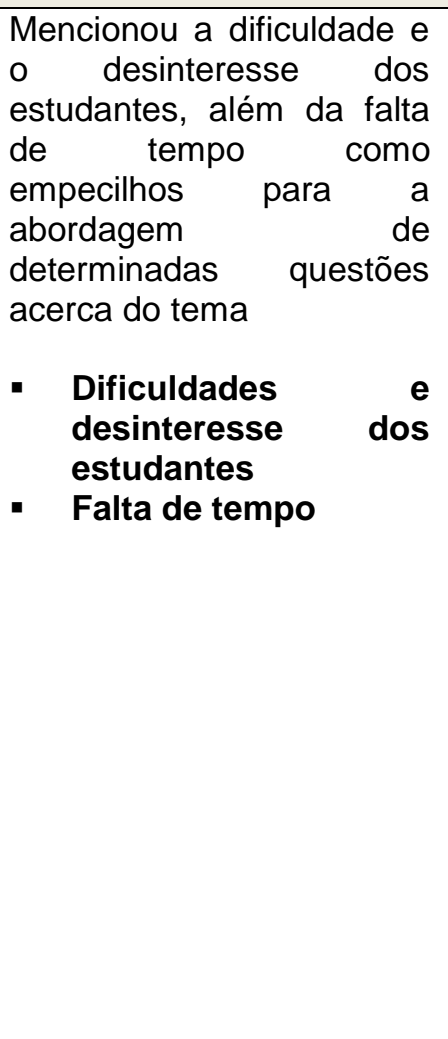 & $\begin{array}{l}\text { Apontou falta de condições } \\
\text { (auxílio e materiais) para } \\
\text { realizar experimentos em } \\
\text { que os estudantes } \\
\text { participem. Mencionou } \\
\text { ainda a falta de tempo, o } \\
\text { desinteresse e a } \\
\text { dificuldade dos alunos } \\
\text { como empecilhos para a } \\
\text { realização de discussões } \\
\text { sobre o tema. Apresentou } \\
\text { uma postura bem } \\
\text { pragmática: não teceu } \\
\text { muitas considerações } \\
\text { sobre a importância das } \\
\text { atividades, mas sim acerca } \\
\text { da possibilidade de realizá- } \\
\text { las, e como ela poderia } \\
\text { tornar isso possível. } \\
\text { Dificuldades } \\
\text { desinteresse } \\
\text { estudantes dos } \\
\text { Falta de tempo } \\
\text { Falta de condições }\end{array}$ & $\begin{array}{l}\text { Citou como melhor } \\
\text { estratégia para trabalhar a } \\
\text { HC o uso de vídeos que } \\
\text { permitam a compreensão } \\
\text { acerca das etapas } \\
\text { envolvidas em processos } \\
\text { para a obtenção de } \\
\text { produtos, o que está } \\
\text { relacionado com a sua } \\
\text { formação como } \\
\text { engenheira. Ademais, } \\
\text { assim como em relação a } \\
\text { outros temas, ela parece } \\
\text { orientar-se a partir de uma } \\
\text { perspectiva pragmática. } \\
\text { Suas principais } \\
\text { preocupações são em } \\
\text { como desenvolver } \\
\text { determinadas questões } \\
\text { nas turmas com as quais } \\
\text { trabalha, e não em como o } \\
\text { trabalho docente pode } \\
\text { favorecer a formação dos } \\
\text { estudantes. } \\
\text { - Formacão acadêmica }\end{array}$ & $\begin{array}{l}\text { O destaque fornecido aos } \\
\text { aspectos quantitativos em } \\
\text { relação a diferentes temas } \\
\text { discutidos nas entrevistas } \\
\text { está associado com a sua } \\
\text { formaçãor como } \\
\text { engenheira. Porém, a } \\
\text { docente também abordou } \\
\text { aspectos qualitativos } \\
\text { ligados a experimentação. } \\
\text { Ela é influenciada por uma } \\
\text { perspectiva pragmática do } \\
\text { que é possível realizar no } \\
\text { contexto no qual ela está } \\
\text { inserida. Ademais, citou as } \\
\text { dificuldades er o } \\
\text { desinteresse dos } \\
\text { estudantes em relação à } \\
\text { possível utilização de } \\
\text { algumas atividades. } \\
\text { Formação acadêmica } \\
\text { - } \\
\text { Dificuldades } \\
\text { desinteresse dos } \\
\text { estudantes }\end{array}$ \\
\hline
\end{tabular}




\begin{tabular}{|c|c|c|c|c|c|}
\hline & $\begin{array}{l}\text { Relações com a } \\
\text { sociedade }\end{array}$ & Modelos e Modelagem & Experimentação & $\begin{array}{c}\text { Desenvolvimento } \\
\text { histórico }\end{array}$ & Reducionismo \\
\hline P5 & $\begin{array}{l}\text { O objetivo de promover o } \\
\text { interesse dos estudantes } \\
\text { pela química parece } \\
\text { orientar a docente em } \\
\text { relação a abordagem de } \\
\text { tais questões. Por isso, } \\
\text { apontou como foco na } \\
\text { consideração das relações } \\
\text { entre química e sociedade } \\
\text { a transmissão de } \\
\text { exemplos do cotidiano dos } \\
\text { estudantes. } \\
\text { Objetivos e papel } \\
\text { docente }\end{array}$ & $\begin{array}{l}\text { Apontou como empecilho } \\
\text { para o trabalho com } \\
\text { algumas questões a falta } \\
\text { de tempo. Entretanto, esse } \\
\text { fator está relacionado com } \\
\text { as prioridades da } \\
\text { professora. Por isso, } \\
\text { embora tenha mencionado } \\
\text { a importância de algumas } \\
\text { questões, seu principal } \\
\text { objetivo é a aprendizagem } \\
\text { de conceitos, visando, } \\
\text { principalmente, promover o } \\
\text { gosto dos estudantes pela } \\
\text { química. } \\
\text { Objetivos e papel } \\
\text { docente } \\
\text { Falta de tempo }\end{array}$ & $\begin{array}{l}\text { Mencionou a falta de } \\
\text { condições materiais ao } \\
\text { apontar a importância de } \\
\text { determinadas atividades } \\
\text { sugeridas. Entretanto, o } \\
\text { que influencia sua prática } \\
\text { e visão acerca das } \\
\text { atividades experimentais } \\
\text { são seus objetivos em } \\
\text { relação ao ensino de } \\
\text { química. Segundo sua } \\
\text { experiência, determinado } \\
\text { modo de desenvolver a } \\
\text { experimentação faz com } \\
\text { que os estudantes tenham } \\
\text { mais interesse e gostem } \\
\text { mais de química. Assim, } \\
\text { utiliza aquelas atividades } \\
\text { que podem atingir esse } \\
\text { objetivo. } \\
\text { - Objetivos e papel } \\
\text { docente }\end{array}$ & 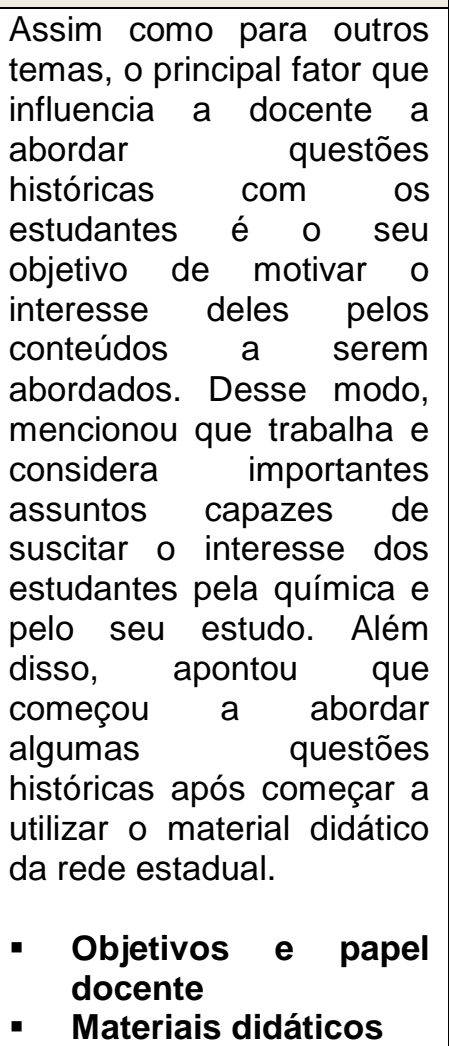 & $\begin{array}{l}\text { Um dos fatores que está } \\
\text { relacionado com o fato de } \\
\text { a docente abordar os } \\
\text { aspectos qualitativos } \\
\text { associados } \\
\text { experimentação, r à } \\
\text { equilíbrio químico e às } \\
\text { classificações é a } \\
\text { finalidade de promover o } \\
\text { interesse dos estudantes } \\
\text { pelo estudo da química. } \\
\text { Tal objetivo leva a docente } \\
\text { a ter uma certa rejeição } \\
\text { inicial em relação à } \\
\text { aplicação da atividade } \\
\text { envolvendo discussões } \\
\text { filosóficas sobre a } \\
\text { estrutura e composição da } \\
\text { água, pois não conseguiria } \\
\text { associar com a } \\
\text { experimentação a ponto } \\
\text { de criar o interesse nos } \\
\text { estudantes. }\end{array}$ \\
\hline
\end{tabular}

Quadro 09: Quadro-resumo dos fatores apontados pelos sujeitos entrevistados que afetam suas concepções e práticas relativas à natureza da química. 
Desse modo, as dificuldades e desinteresse dos estudantes e os objetivos e papel docente, assim como a falta de tempo são os principais fatores que afetam o trabalho e a percepção dos sujeitos entrevistados com relação à inclusão das questões sobre ciência discutidas no decorrer da entrevista. Formação acadêmica e concepções sobre ciência/cientistas estão associados a um número menor de aspectos, enquanto outros fatores estão correlacionados a questões específicas: falta de condições foi identificado nas falas dos docentes exclusivamente acerca da experimentação. Materiais didáticos está relacionado com a consideração do desenvolvimento histórico. Concepções sobre a disciplina de química se refere à abordagem dos temas relações com a sociedade e reducionismo. Por fim, há fatores que foram identificados somente em relação a um aspecto.

Além disso, pode-se notar que alguns fatores estão relacionados entre si. Por exemplo, embora tenha mencionado a influência do material didático da rede estadual na abordagem dos contextos envolvidos no desenvolvimento do processo Haber-Bosch, P5 indicou que passou a incluir alguma discussão a respeito apenas depois de verificar se esse assunto poderia despertar o interesse dos estudantes pelos conteúdos abordados, um de seus principais objetivos ao ensinar. A falta de tempo mencionada por P3, por sua vez, está relacionada com a desmotivação dos alunos. Para o professor, caso houvesse maior interesse pelas questões trabalhadas e uma participação efetiva durante as aulas, mais discussões poderiam ser realizadas em menos tempo. Ainda, a influência do fator objetivos e papel docente está associado com os obstáculos que P3 encontra em sua prática cotidiana. Para o docente P3, muitas discussões sobre a ciência são fundamentais para promover a construção do conhecimento. Entretanto, o fato de achar que o desenvolvimento desse processo depende mais dos estudantes do que do professor faz com que P3 não realize determinadas discussões e acredite não ser possível desenvolvê-las em função das dificuldades e desinteresse dos alunos.

Outra questão relevante é que o mesmo fator pode influenciar os docentes de modo diferente. Por exemplo, P1 apontou que não realizaria determinadas atividades na escola onde atua devido às dificuldades dos estudantes em leitura e escrita. O mesmo fator levou P4 a ponderar acerca das maneiras de contornar tais obstáculos, visando desenvolver as discussões sugeridas. Em relação à concepção sobre quais seriam os conteúdos próprios da disciplina de química, tanto P1 quanto P3 consideraram os contextos associados à ciência e à tecnologia como assuntos 
exógenos à disciplina escolar de química. Apesar disso, enquanto $\mathrm{P} 1$ considera que esses assuntos devem ser tratados em outra disciplina, P3 não tem certeza se deve abordá-los ou não.

Tais constatações estão em consonância com os estudos apresentados por Buehl e Beck (2015) acerca de crenças docentes. Essas pesquisadoras apontam que as crenças existem dentro de um sistema complexo, inter-relacionado e multidimensional. Buehl e Beck (2015) também argumentam que essas crenças podem ser primárias ou fundamentadas em crenças primárias, centrais ou periféricas, e aparecerem juntas ou de forma mais ou menos isolada.

Esse último ponto pode ser observado em relação às falas de P1. No transcurso das entrevistas, ele mencionou reiteradamente as dificuldades de aprendizagem e a falta de interesse dos alunos como obstáculos à realização de certas discussões sobre a ciência. Porém, em nenhum momento, mencionou esses problemas como empecilhos para a consideração dos aspectos práticos e do cotidiano - os quais considera fundamentais no ensino de química. Isso sugere que a sua concepção e prática envolvendo aspectos da química e da ciência é mais influenciada por seus objetivos ao ensinar do que pelos fatores contextuais.

Por outro lado, diversos estudos consideram que fatores do contexto escolar imediato, tais como atitudes e habilidades dos estudantes, gestão da sala de aula e quantidade de alunos, podem impedir os docentes de agir de acordo com suas crenças. Buehl e Beck (2015) mencionam investigações que constataram que a má conduta dos alunos prejudicou a implementação de determinados tipos de instrução. Nesse sentido, como evidencia Wallace (2014), a atitude positiva de um docente acerca de um determinado conteúdo é um fator necessário, porém não suficiente para adoção de uma perspectiva inovadora no ensino de ciências. Por exemplo, embora tenha atribuído importância a muitos aspectos sobre a ciência discutidos no decorrer das entrevistas, e se mostrado favorável à inclusão de alguns deles no ensino de química, P3 apontou que não aborda ou não abordaria algumas questões em função da apatia e das dificuldades dos estudantes com os quais trabalha.

Ainda de acordo com Buehl e Beck (2015), as dificuldades com as quais os professores se deparam em sua prática podem fazer com que orientem suas ações mais pragmaticamente do que teoricamente, assim como foi constatado em relação a P4. No transcorrer das entrevistas, a docente fez poucas considerações sobre a relevância das discussões acerca da ciência para a formação dos estudantes. Ao ser 
questionada a esse respeito, frequentemente apontava os meios pelo quais poderia contornar a indisciplina, o desinteresse e a defasagem dos estudantes em conhecimentos básicos. 


\section{CAPÍTULO 04 - CONSIDERAÇÕES FINAIS}

Esta dissertação buscou investigar as concepções de professores de química sobre o trabalho didático com aspectos da natureza da ciência e, mais especificamente, da química, bem como identificar fatores que afetam a percepção e práticas docentes concernentes à abordagem dessas questões.

Por se tratar de um estudo qualitativo, as análises e discussões aqui desenvolvidas não permitem a enunciação de conclusões gerais e definitivas a respeito das questões colocadas inicialmente. Todavia, e a despeito da natureza complexa envolvendo as relações entre concepções e práticas docentes, as considerações realizadas permitem a reflexão sobre os modos pelos quais se pode favorecer a abordagem de assuntos da HFC no ensino de química, bem como fornecem subsídios para futuras pesquisas.

De maneira geral, esta investigação evidenciou que os sujeitos entrevistados consideram relevantes determinados assuntos relacionados à natureza da ciência e, de certo modo, buscam inseri-los em suas práticas cotidianas. Os docentes fizeram referências a questões que vêm sendo discutidas no âmbito da educação científica já por algum tempo e que, por isso, têm influenciado a elaboração de documentos curriculares oficiais e materiais didáticos. Algumas das concepções apresentadas pelos professores concernentes à experimentação, modelos e modelagem, relações com a sociedade e história da ciência, estão em consonância com as perspectivas preconizadas em pesquisas na área de ensino de ciências e nas orientações curriculares nacionais.

Por outro lado, os resultados sugerem que o motivo pelo qual os professores conferem importância a algumas discussões, e o modo como as desenvolvem, pode limitar a compreensão dos estudantes sobre a complexidade da construção do conhecimento científico e, até mesmo, fomentar visões distorcidas acerca da ciência e do trabalho dos cientistas. Em parte, as considerações feitas por eles sugerem que a inclusão de elementos da HFC em suas práticas tem sido mínima, e que seus objetivos precípuos não incluem a compreensão da complexidade envolvida no processo de construção do conhecimento científico.

Além disso, não houve quaisquer referências à relevância de se evidenciar e discutir, em sala de aula, aspectos característicos da química, tampouco à 
preparação de situações didáticas próximas à prática química autêntica, as quais evidenciem os procedimentos, valores e modos de pensar próprios dessa ciência. Os docentes pareceram desconhecer as peculiaridades epistemológicas e históricas da química como disciplina científica. Alguns, ainda, apresentaram certa resistência e desinteresse em incluir, em sua prática, reflexões filosóficas envolvendo o reducionismo no estudo da química da água, por exemplo.

Tais constatações apontam para a importância de se investigar como as contribuições da filosofia da química podem ser incorporadas em cursos de formação docente inicial e continuada, de modo a promover reflexões sistemáticas acerca dos conceitos, métodos e teorias fundamentais da química.

Este estudo promoveu também a reflexão acerca de fatores que podem afetar as concepções e práticas docentes em relação à utilização da HFC no ensino de química. De maneira geral, tais fatores possuem múltiplas dimensões e podem se apresentar de modo isolado ou em conjunto com outros fatores. Foram identificados fatores internos (relacionados à outras crenças dos sujeitos, aos conhecimentos que possuem acerca das perspectivas abordadas, à formação acadêmica e a preferências pessoais) e fatores externos (relativos ao contexto no qual os docentes estão inseridos e aos materiais didáticos que influem em suas práticas). Alguns desses fatores estão associados à maioria dos aspectos investigados, enquanto outros se relacionam a questões específicas.

As concepções sobre os objetivos do ensino de química e o papel docente foram o principal fator interno identificado no discurso dos sujeitos investigados. Estudos apontam que, historicamente, professores experientes - como os sujeitos dessa pesquisa -, se recusam a implementar uma perspectiva contrária às suas crenças centrais, considerando relevantes apenas questões que estão em consonância com elas. Entretanto, embora tais crenças sejam relativamente estáveis, as pesquisas evidenciam a possibilidade de modificá-las, principalmente, por meio da tomada de consciência dos docentes a respeito de suas crenças centrais - as quais estão de acordo com determinados princípios subjacentes a uma dada inovação curricular -, bem como mediante a pesquisa-ação e reflexões por um longo período de tempo (Wallace, 2014).

$\mathrm{Na}$ presente investigação, os professores descreveram práticas pedagógicas que potencialmente podem ser utilizadas para discutir assuntos sobre a natureza da química. Ademais, atribuíram importância a questões acerca dessa perspectiva. 
Assim, cabe a questão: em que medida promover a consciência dos docentes acerca de tais práticas e concepções, assim como fomentar a reflexão a respeito delas e das relações que estas estabelecem com as características inerentes da química, contribui efetivamente para a inclusão de elementos da HFC no ensino?

Essa questão pode ser investigada em pesquisas futuras, as quais tenham por intuito identificar o potencial dessa e de outras estratégias em provocar mudanças nas concepções docentes de maneira a favorecer a inclusão da HFC no ensino e o engajamento dos estudantes em atividades investigativas que se aproximem da prática química autêntica.

Uma das estratégias que podem ser investigadas de modo mais detido e aprofundado consiste em identificar as concepções dos docentes acerca da utilização da HFC no ensino mediante o emprego de atividades didáticas que encerram discussões epistemológicas e históricas sobre a química. Conforme se observou na presente pesquisa, há algumas dificuldades envolvidas nessa tarefa, dentre as quais se destaca o desafio de distinguir as opiniões dos sujeitos sobre o modo como as atividades estão desenvolvidas das suas concepções acerca das discussões e reflexões que elas ensejam. Em função disso, foi necessário, em diversas ocasiões, no transcorrer das entrevistas, repetir as questões realizadas, dirigindo a atenção dos sujeitos para o que se pretendia, de modo a atender os objetivos da pesquisa. Isso fez com que algumas entrevistas se estendessem mais do que o planejado, correndo o risco de se tornarem cansativas para os entrevistados. Contudo, apesar desses desafios, algumas falas dos docentes sugerem que a utilização dessas perguntas promove a reflexão acerca de assuntos a respeito dos quais talvez eles não tenham oportunidade de considerar em outras ocasiões, como a abordagem de questões sobre a natureza específica da química.

A identificação de fatores externos, pertinentes ao contexto docente, sugere que uma atitude positiva em relação a discussões epistemológicas é uma condição necessária, porém não suficiente, para a inclusão de elementos da HFC no ensino de química. Consequentemente, o trabalho pedagógico sob essa perspectiva não depende somente da compreensão dos docentes sobre a história e a filosofia da química, tampouco da consonância entre os seus objetivos e as investigações educacionais. É necessário que os cursos de formação inicial e continuada, além de promover estudos acerca da natureza da ciência e da química, forneçam exemplos de como atividades didáticas que envolvam tais aspectos podem ser utilizadas em 
sala de aula. Entretanto, mais relevante ainda é criar oportunidades para que os docentes, a partir da ponderação a respeito de suas condições concretas de trabalho e da consideração sobre a relevância dessas perspectivas na formação dos estudantes, possam construir os meios necessários à promoção de um ensino de química mais autêntico, o qual articule a aprendizagem dos conhecimentos químicos, dos processos pelos quais esses conhecimentos foram elaborados e dos procedimentos, valores e modos de pensar que caracterizam a química. 


\section{REFERÊNCIAS BIBLIOGRÁFICAS}

ABD-EL-KHALICK, F. Teaching with and about nature of science, and science teacher knowledge domains. Science \& Education, v. 22, n. 9, p. 2087-2107, 2013.

ABD-EL-KHALICK, F.; BELL, R. L.; LEDERMAN, N. G. The nature of science and instructional practice: making the unnatural natural. Science Education, v. 82, n. 4, p. 417-436, 1998.

ABD-EL-KHALICK, F.; LEDERMAN, N. G. Improving science teachers' conceptions of nature of science: a critical review of the literature. International Journal of Science Education, v. 22, n. 7, p. 665-701, 2000.

ADÚRIZ-BRAVO, A. Integración de la epistemologia em la formación del professorado de ciencias. 2001. 637 f. Tese - Departament de Didàctica de les Matemàtiques i de lês Ciències Experimentals, Universitát Autònoma de Barcelona, Bellaterra. 2001.

AIKENHEAD, G. S. Review of research on humanistic perspectives in science curricula. In: 4TH CONFERENCE OF THE EUROPEAN SCIENCE EDUCATION RESEARCH ASSOCIATION (ESERA), 2003, Noordwijkerhout, The Netherlands.

AKERSON, V.; ABD-EL-KHALICK, F.; LEDERMAN, N. G. Influence of a reflective activity-based approach on elementary teachers' conceptions of nature of science. Journal of Research in Science Teaching, v. 37, n. 4, p. 295-317, 2000.

ALLCHIN, D. Pseudohistory and pseudoscience. Science \& Education, v. 13, n. 3, p. 179-195, 2004.

ALLCHIN, D. Rekindling Phlogiston. Disponível em: $<$ http://www1.umn.edu/ships/modules/chem/RekindlingPhlogiston.pdf $>$. Acesso em: 30 out. 2015.

ALTERS, B.J. Whose nature of science? Journal of Research in Science Teaching, v. 34, n.1, p. 39-55,1997.

ARAÚJO, M. C.; BALDINATO, J. O. A síntese de amônia: uma proposta de estudo histórico para a formação de professores de química vinculada ao Prêmio Nobel de Fritz Haber. História da Ciência e Ensino: construindo interfaces. v. 11, p. 91-129, 2015.

ARROIO, A.; GIORDAN, M. O vídeo educativo: aspectos da organização do ensino. Química Nova na Escola, v. 24, p. 8-11, 2006.

BALDWIN, M.; CLOUGH, M.; GREENBOWE, T. A puzzle with many pieces: developments of the periodic table. Disponível em: < http://www.storybehindthescience.org/pdf/periodic.pdf> Acesso em: 27 out. 2015. 
BAPTISTA, M. L. M. Concepção e implementação de actividades de investigação: um estudo com professores de física e química do ensino básico. 2010. 586 f. Tese (Doutorado em Educação) - Instituto de Educação, Universidade de Lisboa, Lisboa.

BARNETT, J.; HODSON, D. Pedagogical context knowledge: toward a fuller understanding of what good science teachers know. Science Education, v. 85, n. 4, p. 426-453, 2001.

BASTOS, F. História da ciência e pesquisa em ensino de ciências: breves considerações. In: NARDI, R. (Org.). Questões atuais no ensino de ciências. São Paulo: Escrituras, 1998.

BELTRAN, M.H.R.; SAITO, F.; TRINDADE, L.S.P. História da ciência para formação de professores. São Paulo: Editora Livraria da Física, 2014. 128 p.

BENSAUDE-VINCENT, B. Philosophy of chemistry. In: BRENNER, A; GAYON, J. (Eds.). French Studies in the Philosophy of Science, Boston Studies in the Philosophy of Science, Dordrecht: Springer, 2009. p. 165-185.

BERNAL, A.; DAZA, E. E. On the epistemological and ontological status of chemical relations. HYLE- International Journal of Philosophy of Chemistry, v.16, n.2, p. 80103, 2010.

BOGDAN, R.; BIKLEN, S. Investigação qualitativa em educação: uma introdução à teoria e aos métodos. Trad. Alvarez, dos Santos e Baptista, Porto: Porto Editora, 1994, $335 \mathrm{p}$.

BRASIL. Lei de Diretrizes e Bases da Educação Nacional. Lei 9.394, de 20 dez. 1996. Diário Oficial da República Federativa do Brasil, Brasília, 23 dez.1996.

. Ministério da Educação. Secretaria da Educação Média e Tecnológica. Parâmetros Curriculares Nacionais (Ensino Médio). Brasília, 1999.

Ministério da Educação. Secretaria de Educação Média e Tecnológica. PCN+ Ensino Médio - Orientações Educacionais Complementares aos Parâmetros Curriculares Nacionais. Ciências da natureza, matemática e suas tecnologias. Brasília, 2002.

Ministério de Educação. Secretaria de Educação Básica. Orientações curriculares para o Ensino Médio. Brasília: MEC/SEB, 2006.

BUEHL, M. M.; BECK, J. S. The relationship between teachers' beliefs and teachers' practices. In: FIVES, H.; GILL, M. G. (Eds.). International handbook of research on teachers' beliefs. Nova York: Routledge, 2015. p. 66-84.

CACHAPUZ, A. et al. A emergência da didática das ciências como campo específico de conhecimentos. In: CACHAPUZ, A. et al. (Orgs.). A necessária renovação do ensino de ciências. São Paulo: Editora Cortez, 2005. p.185-230. 
CAPECCHI, M.C.V.M \& CARVALHO, A.M.P. Argumentação em uma aula de conhecimento físico com crianças na faixa de oito a dez anos. Investigações em Ensino de Ciências, v.5, n.3, p. 171-189, 2000.

CARVALHO, J. S. F. Autonomia e autoridade no construtivismo: uma crítica às concepções de Piaget. In: AQUINO, J. G. (Org.). Autoridade e autonomia na escola: alternativas teóricas e práticas. São Paulo: Summus, 1999. p. 49-70.

CHAMIZO, J. A. Technochemistry: one of the chemists' ways of knowing. Foundations of Chemistry, v. 15, n. 2, p. 157-170, 2013.

. The role of instruments in three chemical revolutions. Science and Education, v. 23, n. 4, p. 955-982, 2014.

CHAVES, Silvia Nogueira. História da ciência através do cinema: dispositivo pedagógico na formação de professores de ciências. Alexandria: Revista de Educação em Ciência e Tecnologia, v. 5, n. 2, p. 83-93, 2012.

CORRÊA, R. G. Estudo do perfil motivacional para o aprendizado de química. 2009. 160 f. Dissertação (Mestrado em Química) - Departamento de química, Universidade Federal de São Carlos, São Carlos. 2009.

DE JONG, O.; VAN DRIEL, J. H.; VERLOOP, N. Preservice teachers' pedagogical content knowledge of using particle models in teaching chemistry. Journal of Research in Science Teaching, v. 42, n. 8, p. 947-964, 2005.

DÍAZ, J.A.A.; ALONSO, A.V; MAS, M.A.M, "Papel de la educación CTS en una alfabetización científica y tecnológica para todas las personas", Revista Electrónica de Enseñanza de las Ciencias, v. 2, n. 2, 2003. $<$ https://reec.uvigo.es/volumenes/volumen2/REEC 22 1.pdf >. Acesso em: 2 nov. 2015.

DIBATTISTA, L.; MORGESE, F. Introducing history (and philosophy) of science in the classroom: a field research experience in Italy. Science \& Education, v. 22, n. 3, p. 543-576, 2013.

DUARTE, R. Entrevistas em pesquisas qualitativas. Educar, n. 24, p. 213-225, 2004.

EFLIN, J.T.; GLENNAN, S.; REISCH, G. The nature of science: a perspective from the philosophy of science. Journal of Research in Science Teaching, v. 36, n. 1, p.107-116.

ERDURAN, S. Merging curriculum design with chemical epistemology: a case of teaching and learning chemistry through modeling. 1999. $189 \mathrm{f}$. Tese (Doutorado em filosofia) - Vanderbilt University, Nashville, Tennesse. 1999.

. Philosophy of chemistry: an emerging field with implications for chemistry education. Science \& Education, v. 10, n. 6, p. 581-593, 2001. 
Applying the philosophical concept of reduction to the chemistry of water: Implications for chemical education. Science \& Education, v. 14, n. 2, p. 161-171, 2005.

. Breaking the law: promoting domain-specificity in chemical education in the context of arguing about the periodic law. Foundations of Chemistry, v. 9, n. 3, p. 247-263, 2007.

ERDURAN, S.; ADÙRIZ-BRAVO, A.; NAAMAN, R. M. Developing epistemologically empowered teachers: examining the role of philosophy of chemistry in teacher education. Science \& Education, v. 16, n. 9-10, p. 975-989, 2007.

ERDURAN, S.; SCERRI, E. The nature of chemical knowledge and chemical education. In: GILBERT, J. et al. (Ed.). Chemical education: towards research-based practice. Dordrecht: Kluwer Academic Publishers. 2002. p.7-27.

FABRICIO, C. M.; GUIMARÃES, L. M.; AIRES, J. A. Lavoisier e a combustão: uma proposta para o Ensino de química baseada na história e filosofia da Ciência. In: ENCONTRO NACIONAL DE PESQUISA EM EDUCAÇÃO EM CIÊNCIAS, 8., 2011, Campinas. Anais do VIII ENPEC, Campinas, SP, 2011. Disponível em: < http://www.nutes.ufri.br/abrapec/viiienpec/resumos/R0042-2.pdf>. Acesso em: 3 jul. 2014.

FERNANDEZ, I. et al. Visiones deformadas de la ciencia transmitidas por la enseñanza. Enseñanza de las Ciencias, v. 20, n. 3, p. 477-488, 2002.

FIVES, H.; BUEHL, M. M. (2012). Spring cleaning for the "messy" construct of teachers' beliefs: what are they? Which have been examined? What can they tell us? In: HARRIS, K. R.; GRAHAM, S; URDAN. T. (Eds.). APA educational psychology handbook: individual differences and cultural and contextual factors, v.2. Washington: American Psychological Association, 2012. p. 471-499.

FORATO, T. C. M.; PIETROCOLA, M.; MARTINS, R. A. Historiografia e natureza da ciência na sala de aula. Caderno Brasileiro de Ensino de Física, v. 28, n; 1, p. 27-59, 2011.

GAGLIARDI, R. Cómo utilizar la historia de las ciencias en la enseñanza de las ciencias. Enseñanza de las Ciencias, v. 6, n. 3, p. 291-296, 1988.

GALIAZZI, M.C. et al. Objetivos das atividades experimentais no ensino médio: a pesquisa coletiva como modo de formação de professores de ciências. Ciência \& Educação, v. 7, n. 2, p. 249-263, 2001.

GALILI, I.; HAZAN, A. The influence of an historically oriented course on students' content knowledge in optics evaluated by means of facets-schemes analysis. American Journal of Physics, v. 68 (S1), n. 7, S3-S15, 2000. 
GIL-PÉREZ, D. et al. Para uma imagem não deformada do trabalho científico. Ciência \& Educação, v. 7, n. 2, p. 125-153, 2001.

GONÇALVES, F. P. O texto de experimentação na educação em química: discursos pedagógicos e epistemológicos. 2005. 168 f. Dissertação (Mestrado em Educação Científica e Tecnológica) - Universidade Federal de Santa Catarina, Florianópolis. 2005.

GUIMARÃES, S. E. R. Avaliação do estilo motivacional do professor: adaptação e validação de um instrumento. 2003. 189 f. Tese (Doutorado em Educação) Faculdade de Educação, Universidade Estadual de Campinas, Campinas.

HODSON, D. Uma visão crítica em relação ao trabalho prático nas aulas de ciências. School Science Review, v. 71, n. 256, 1989. Tradução e adaptação de Andréa Horta Machado (UFMG).

HODSON, D. Hacia un enfoque más crítico del trabajo de laboratorio. Enseñanza de las Ciencias. v. 12, n. 3, p. 299-313, 1994.

HOFFMAN. R. O mesmo e o não-mesmo. Tradução de Roberto Leal Ferreira. São Paulo: Editora UNESP, 2007. $341 \mathrm{p}$.

HOFSTEIN, A.; KIPNIS, M.; ABRAHAMS, I. How to learn in and from the chemistry laboratory. In: EILKS, I; HOFSTEIN, A. (Eds.). Teaching chemistry - a studybook: a practical guide and textbook for student teachers, teacher trainees and teachers. Rotterdam: Sense Publishers, 2013. p. 153-182.

HÖTTECKE, D.; HENKE A.; RIESS, F. Implementing history and philosophy in science teaching: strategies, methods, results and experiences from the European HIPST Project. Science \& Education, Dordrecht, v. 21, n. 9, p. 1233--1261, 2012.

HÖTTECKE, D.; SILVA, C. C. Why implementing history and philosophy in school science education is a challenge: an analysis of obstacles. Science \& Education, Dordrecht, v. 20, n. 3-4, p. 293-316, 2011.

IRZIK, G.; NOLA, R. A family resemblance approach to the nature of science for science education. Science \& Education. Dordrecht, v. 20, n. 7-8, p. 591-607, 2011.

IZQUIERDO-AYMERICH, M. School chemistry: an historical and philosophical approach. Science \& Education. Dordrecht, v. 22, n. 7, p. 1633-1653, 2013.

JIMÉNEZ-ALEIXANDRE, M. P.; BUGALLO RODRÍGUEZ, A.; DUSCHL, R. A. "Doing the lesson" or "doing science": argument in high school genetics. Science Education, v. 84, n. 6 , p. 757-792, 2000.

JOHNSTONE, A. H. The development of chemistry teaching. Journal of Chemical Education, v. 70, n. 9, p. 701-705, 1993. 
JUSTI, R. Modelos e modelagem: um olhar sobre aspectos essenciais pouco discutidos. In: SANTOS, W. L. P.; MALDANER, O. A. (Orgs.). Ensino de química em foco. ljuí: Editora ljuí, 2010. p. 209-230.

JUSTI, R.; GILBERT, J. History and philosophy of science through models: some challenges in the case of 'the atom'. International Journal of Science Education, v. 22 , n. 9, p. 993-1009, 2000.

JUSTI, R.; GILBERT, J. Models and modelling in chemical education. In: GILBERT, J.; DE JONG, O.; JUSTI, R.; TREAGUST; D. F.; VAN DRIEL, J. H. (Eds.). Chemical education: towards research-based practice. Dordrecht: Kluwer, p. 47-68, 2003.

KING, D. T. New perspectives on context-based chemistry education: using a dialectical sociocultural approach to view teaching and learning. Studies in Science Education, v. 48, n. 1, p. 51-87, 2012.

KOLST Ø, S.D. Science education for democratic citizenship through the use of the history of science. Science \& Education, Dordrecht, v. 17, n. 8-9, p. 977-997, 2008.

KOVAC, J. Theoretical and practical reasoning in chemistry. Foundations of Chemistry, v. 4, n. 2, p. 163-171, 2002.

LABARCA, M.; BEJARANO, N.; EICHLER, M. L. Química e filosofia: rumo a uma frutífera colaboração. Química Nova, São Paulo, v. 36, n. 8, 2013. Disponível em: $<$ http://www.scielo.br/scielo.php?script=sci_arttext\&pid=S0100-

$40422013000800027 \&$ Ing=en\&nrm=iso>. Acesso em: 30 out. 2015.

LEDERMAN, N. G. Nature of science: past, present, and future. In: ABELL, S.K.; LEDERMAN, N. G. (Eds.). Handbook of research on science education. Mahwah: Lawrence Erlbaum Associates, 2007, p. 831-880.

LEDERMAN, N.G.; ABD-EL-KHALICK, F.; BELL, R.L.; SCHWARTZ, R.S. Views of nature of science questionnaire: toward valid and meaningful assessment of learners' conceptions of nature of science. Journal of Research in Science Teaching. v. 39, n. 6, p. 497-52, 2002.

LEFÈVRE, W. Viewing chemistry through its way of classifying. Foundation of Chemistry. v. 14, n. 1, p. 25-36, 2012.

LEITE, H.S.A.; PORTO, P. A. Análise da abordagem histórica para a tabela periódica em livros de química geral para o ensino superior usados no Brasil no século XX. Quimíca Nova, v. 38, n. 4, p. 580-587, 2015.

LEMES, A.F.G. Aspectos filosóficos e educacionais da química: investigando as concepções de doutorandos em química. 2013. 179 f. Dissertação (Mestrado em Ensino de Ciências) - Faculdade de Educação, Instituto de Física, Instituto de química e Instituto de Biociências, Universidade de São Paulo, São Paulo, 2013. 
LEVIN, B. The development of teachers' beliefs. In: FIVES, H.; GILL, M. G. (Eds.). International handbook of research on teachers' beliefs. Nova York: Routledge, 2015. p. 48-65.

LOMBARDI, O.; LABARCA; M. The philosophy of chemistry as a new resource for chemistry education. Journal of Chemical Education, v. 84, n. 1, p. 187-192, 2007.

LOPES, A. R. C. Conhecimento escolar: ciência e cotidiano. Rio de Janeiro: EdUERJ, 1999. 236 p.

MALDANER, O. A. A formação inicial e continuada de professores de química: professores pesquisadores. ljuí: Ed. UNIJUÍ, 2000.

MARTINS, A. F. P. história e filosofia da ciência no ensino: há muitas pedras nesse caminho... Caderno Brasileiro de Ensino de Física, Florianópolis, v. 24, n. 1, p. 112131, 2007.

. História, filosofia, ensino de ciências e formação de professores: desafios, obstáculos e possibilidades. Educ. Teoria Prática, Rio Claro, v. 22, n. 40, ago. 2012. Disponível em < http://educa.fcc.org.br/pdf/eduteo/v22n40/v22n40a02.pdf >. Acesso em: 30 out. 2015.

MARTINS, R. A. Sobre o papel da história da Ciência no ensino. Boletim da Sociedade Brasileira de História da Ciência v.9, p. 3-5, 1990.

MATTHEWS, M. história, filosofia e ensino de ciências: a tendência atual de reaproximação. Caderno Catarinense de Ensino de Física, v. 12, n. 3, p. 164-214, 1995.

. The nature of science and science teaching'. In: FRASER, B.; TOBIN, K. (Ed.), International handbook of science education, Dordrecht: Kluwer Academic Publishers, 1998. v. 2, p. 981-999.

. Changing the focus: from the nature of science (NOS) to features of science (FOS). In KHINE, M. S. (Ed.), Advances in Nature of Science Research. Dordrecht: Springer, 2012. p. 3-26.

McCOMAS, W. F.; ALMAZROA, H.; CLOUGH, M. P. The nature of science in science education: an introduction. Science \& Education, Dordrecht, v. 7, n. 6, p. 511-532, 1998.

McCOMAS, W.; CLOUGH, M.; ALMAZROA, H. The role and character of the nature of science in science education. In: McCOMAS, W. F. (Ed.). The nature of science in science education: rationales and strategies. Dordrecht: Kluwer Academic Publishers, 1998. p. 3-39.

McCOMAS, W. F.; OLSON, J. K. The nature of science in international science education standards documents. In: (Ed.). The nature of science in science education: rationales and strategies. Dordrecht: Kluwer Academic Publishers, 1998. p. 41-52. 
MELLADO, V. Formácion del profesorado de ciencias y buenas prácticas: el lugar de la innovación y la investigación didáctica. In: CAAMAÑO, A. (Coord.). Física y química: investigación, innovación y buenas prácticas. Barcelona: Ed. Graó, 2011. p. 11-26.

MELO, M. R. Estrutura atômica e ligações químicas: uma abordagem para o ensino médio. 2002. 128 f. Dissertação (Mestrado) - Departamento de Química Inorgânica, Universidade Estadual de Campinas, Campinas. 2002.

MENDONÇA, P.C.C. 'Ligando' as ideias dos alunos à ciência escolar: análise do ensino de ligação iônica por modelagem. 2008. 231 f. Dissertação (Mestrado em Educação) - Universidade Federal de Minas Gerais. Faculdade de Educação, Belo Horizonte, 2008.

Influência de atividades de modelagem na qualidade dos argumentos de estudantes de química do ensino médio. 2011. 272 f. Tese (Doutorado em Educação) - Universidade Federal de Minas Gerais. Faculdade de Educação, Belo Horizonte, 2011.

MENDONÇA, P.C.C; JUSTI, R. Construção de modelos no ensino de ligação iônica. In: ENCONTRO NACIONAL DE PESQUISA EM EDUCAÇÃO EM CIÊNCIAS,5, 2005, Bauru. Atas... Bauru: UNESP, 2005.

MINAYO, M.C. O desafio do conhecimento, pesquisa qualitativa em saúde. São Paulo-Rio de Janeiro: Hucitec/Abrasco, 1992. 269 p.

NASCIMENTO, S. S; VIEIRA, R. D. Contribuições e limites do padrão de argumento de Toulmin aplicado em situações argumentativas de sala de aula de ciências. Revista Brasileira de Pesquisa em Educação em Ciências, v. 8, n. 2, 2008.

OSBORNE, J. Science education for the twenty first century. Eurasia Journal of Mathematics, Science \& Technology Education, v. 3, n. 3, p. 173-184, 2007.

OSBORNE, J.; COLLINS, S.; RATCLIFFE, M.; MILLAR, R.; DUSCHL, R. What 'ideas-about-science' should be taught in school science?: a delphi study of the expert community. Journal of Research in Science Teaching, v. 40, n. 7, p. 692-720, 2003

OSBORNE, J.; DUSCHL, R. A.; FAIRBROTHER, R. W. Breaking the mould?: teaching science for public understanding. London: Nuffield Foundation, 2002.

PAIXÃO, M. F.; CACHAPUZ, A. Mass conservation in chemical reactions: the development of an innovative teaching strategy based on the history and philosophy of Science. Chemistry Education Research and Practice, v.1, n. 2, p. 201-215, 2000.

PAJARES, M. F. Teachers' beliefs and educational research: cleaning up a messy construct. Review of Educational Research, v. 62, n. 3, p. 307-332, 1992. 
PAULA, Helder de Figueiredo; LIMA, M. E. C. C. Educação em ciências, letramento e cidadania. Química Nova na Escola, v. 26, p. 3-9, 2007.

PEREIRA, J. A. A investigação sobre o uso do corpo em aulas de química. 2013. 120 f. Dissertação (Mestrado) - Universidade Federal de São João del-Rei, São João del-Rei, 2013.

PORTO, P.A. História e filosofia no ensino de química: em busca dos objetivos educacionais da atualidade. In: SANTOS, W. L. P.; MALDANER, O. A. (orgs.). Ensino de química em foco. Ijuí: Editora ljuí, 2010. p.159-180.

RIBEIRO, M. A. P. Integração da filosofia da química no currículo de formação inicial de professores: contributos para uma filosofia do ensino. 2014. $390 \mathrm{f}$. Tese (Doutorado em Educação) - Instituto de Educação, Universidade de Lisboa, Lisboa, 2014.

ROZENTALSKI, E. F. O estatuto ontológico e epistemológico do conceito de orbital em livros didáticos de química geral no sec. XX: uma análise de seus fundamentos, suas representações e implicações para a aprendizagem. 2013. 167 f. Dissertação (Mestrado) - Faculdade de Educação, Instituto de Física, Instituto de química e Instituto de Biociências, Universidade de São Paulo, São Paulo, 2013.

SÃO PAULO (Estado). Secretaria da Educação. Proposta curricular do Estado de São Paulo: química/Coord. Maria Inês Fini. São Paulo. SEE, 2008.

SÃO PAULO (Estado). Secretaria da Educação. Currículo do Estado de São Paulo: química. In: Currículo do Estado de São Paulo: ciências da natureza e suas tecnologias. São Paulo: SE, 2011. p. 126-156.

. Caderno do professor: química, ensino médio, 1a série. Coord. Geral: FINI, M.I. Equipe: ZAMBOM, D.M.; SOUZA, F.L.; PEIXOTO, H.R.C.; SANTOS, I.V.S.; AKAHOSHI, L.H.; MARCONDES, M.E.R; LAMAS, M.F.P.; ESPERIDIÃO, Y.M. São Paulo: SEE, volumes 2 e 3, 2009a.

. Caderno do professor: química, ensino médio, $2^{\mathrm{a}}$ série. Coord. Geral: FINI, M.I. Equipe: ZAMBOM, D.M.; SOUZA, F.L.; PEIXOTO, H.R.C.; SANTOS, I.V.S.; AKAHOSHI, L.H.; MARCONDES, M.E.R; LAMAS, M.F.P.; ESPERIDIÃO, Y.M. São Paulo: SEE, volume 2, 2009b.

. Caderno do aluno: química, ensino médio, $1^{a}$ série. Coord. Geral: FINI, M.I. Equipe: ZAMBOM, D.M.; SOUZA, F.L.; PEIXOTO, H.R.C.; SANTOS, I.V.S.; AKAHOSHI, L.H.; MARCONDES, M.E.R; LAMAS, M.F.P.; ESPERIDIÃO, Y.M. São Paulo: SEE, volumes 2 e 3, 2009c.

. Caderno do aluno: química, ensino médio, $2^{\underline{a}}$ série. Coord. Geral: FINI, M.I. Equipe: ZAMBOM, D.M.; SOUZA, F.L.; PEIXOTO, H.R.C.; SANTOS, I.V.S.; AKAHOSHI, L.H.; MARCONDES, M.E.R; LAMAS, M.F.P.; ESPERIDIÃO, Y.M. São Paulo: SEE, volumes 2 e 3, 2009d. 
Caderno do aluno: química, ensino médio, $3^{\underline{a}}$ série. Coord. Geral: FINI, M.I. Equipe: ZAMBOM, D.M.; SOUZA, F.L.; PEIXOTO, H.R.C.; SANTOS, I.V.S.; AKAHOSHI, L.H.; MARCONDES, M.E.R; LAMAS, M.F.P.; ESPERIDIÃO, Y.M. São Paulo: SEE, volumes 1 e 2, 2009 e.

SASSERON, L. H.; CARVALHO, A. M. P. Alfabetização científica: uma revisão bibliográfica. Investigações em Ensino de Ciências, v. 16, n. 1, mar. 2011. Disponível em: <http://www.if.ufrgs.br/ienci/artigos/Artigo_ID254/v16_n1_a2011.pdf>. Acesso em: 27 jun. de 2014.

SCERRI, E. R. La nueva filosofía de la química y su importancia en la educacion química. In: CHAMIZO, J. A. (Ed) La esencia de la química: reflexiones sobre filosofía y educación. México: FQ-UNAM, 2007. p.181-192.

SCHUMACHER, A.; REINERS, C.S. Designing authentic learning environments in chemistry lessons: paving the way in pre-service teacher education. Science \& Education, Dordrecht, v. 22, n. 9, p. 2173-2191, 2013.

SCHUMMER, J. The chemical core of chemistry I: a conceptual approach. HYLEInternational Journal of Philosophy of Chemistry, v. 4, n.2, p. 129-162, 1998.

. Coping with the growth of chemical knowlege: challenges for chemistry documentation, education and working chemists. Educación química, v. 10, n. 2, p. 92-101, 1999.

The impact of instrumentation on chemical species identity from chemical substances to molecular species. In: MORRIS, P.J.T. (Ed.). From classical to modern chemistry: the instrumental revolution. Cambridge: Royal Society of Chemistry, 2002. p. $188-211$.

Why do chemists perform experiments? In: SOBCZYNSKA, D. et al. (Eds.). Chemistry in the philosophical melting pot, Frankfurt: Peter Lang, 2004. p. 395-410.

. La filosofia de la química: de la infancia hacia la madurez. In: BAIRD, D.; SCERRI, E.; McINTYRE, L. (Eds.). Filosofía de la química: síntesis de uma nueva disciplina. Trad. de Gerardo Noriega. Mexico: FCE, 2011. p. 36-70.

SHULMAN, L. S. Those who understand: Knowledge growth in teaching. Educational Researcher, v. 15, n. 2, p. 4-14, 1986

SILVA, R. R.; MACHADO, P.F.L.; TUNES, E. Experimentar sem medo de errar. In: SANTOS, W. L. P.; MALDANER, O. A (Orgs.). Ensino de química em foco. ljuí: Editora ljuí, 2010. p. 231-261.

SJÖSTRÖM, J. The Discourse of chemistry (and beyond). HYLE- International Journal of Philosophy of Chemistry, v. 13, n.2, p. 83-97, 2007. 
SJÖSTRÖM, J.; TALANQUER, V. Humanizing chemistry education: from simple contextualization to multifaceted problematization. Journal of Chemical Education, v. 91, n. 8, p. 1125-1131, 2014.

SOLBES, J.; TRAVER, M.; Against a negative image of science: history of science and the teaching of physics and chemistry. Science \& Education, v. 12, n. 7, p. 703717, 2003.

TALANQUER, V. School chemistry: the need for transgression. Science \& Education, v. 22, n. 7, p. 1757-1773, 2013.

TARDIF, M. Saberes docentes e formação profissional. Petrópolis: Vozes, 2002.

THOMPSON, A. Teachers' beliefs and conceptions: a synthesis of the research. In: GROWS, D. A. (Ed.) Handbook of research on mathematics teaching and learning. Virginia: The National Council of Teachers of Mathematics, 1992, p. 127-146.

TOLVANEN, S.; JANSSON, J.; VESTERINEN, V.; AKSELA, M. How to use historical approach to teach nature of science in chemistry education? Science \& Education, OnLine First, 2013.

TREAGUST, D.F.; CHITTLEBOROUGH, G. Chemistry: a matter of understanding representations. In: BROPHY, J. (Orgs.). Subject-specific instructional methods and activities. New York: Emerald Group Publishing Limited, v.8, 2001, p.239-267.

VAN DRIEL, J. H.; BULTE, A. M.W.; VERLOOP, N. The conceptions of chemistry teachers about teaching and learning in the context of a curriculum innovation. International Journal of Science Education, v. 27, n. 3, p. 303-322, 2005.

VESTERINEN, V.-M. Nature of science for chemistry education: design of chemistry teacher education course. 2012. 60 f. Dissertação - Department of Chemistry University of Helsinki, Helsinki, 2012.

VESTERINEN, V.-M.; AKSELA, M.; SUNDBERG, M. Nature of chemistry in the national frame curricula for upper secondary education in Finland, Norway and Sweden. Nordic Studies in Science Education, v. 5, p. 200-212, 2009.

VIEIRA, R. D.; NASCIMENTO, S. S. Uma visão integrada dos procedimentos discursivos didáticos de um formador em situações argumentativas de sala de aula. Ciência e Educação, v. 15, n. 3, p. 443-457, 2009.

VILLANI, A. filosofia da ciência e ensino de ciência: uma analogia. Ciência \& Educação, v. 7, n. 2, p. 169-181, 2001.

WALLACE, C. S. Overview of the role of teacher beliefs in science education. In: EVANS, R.; LUFT, J.; CZERNIAK, C.; PEA; C. The role of science teachers' beliefs in international classrooms: from teacher's action to student learning. Rotterdam: Sense Publishers, 2014. p. 17-31. 
WANG, H. A.; COX-PETERSEN, A.M. A comparison of elementary, secondary and student teachers' perceptions and practices related to history of science instruction. Science \& Education, v. 11, n. 1, p. 69-81, 2002.

ZABALA, A. A prática educativa: como ensinar. Porto Alegre: ArtMed, 1998. 224 p. 


\section{APÊNDICE A - Roteiro de entrevista}

\section{A - Caracterização do entrevistado e das condições de trabalho docente}

- Há quanto tempo você é professor (a)?

- Qual a sua formação?

- Possui experiência em outras áreas? Quais?

- Quantas aulas você leciona por semana? De quantas reuniões participa?

\section{B - Identidade docente}

- Por que você escolheu ser professor?

- Como você se tornou professor de química? Quais caminhos o levaram a essa profissão?

- Em sua opinião, qual o seu papel como professor de química? Qual a importância do professor de química na sociedade?

\section{C - Saberes necessários ao trabalho docente}

- Em sua opinião, quais assuntos são tratados em um bom programa de formação continuada? Por quê?

- O que você acha que um professor de química deve saber e saber fazer para atingir seus objetivos? Por quê?

- Em sua opinião, quais são as suas principais dificuldades como professor de química?

\section{D - Objetivos pedagógicos e práticas docentes}

- Para você, quais devem ser os principais objetivos do ensino de química? Por quê? Em sua opinião, por meio de quais estratégias esses objetivos podem ser atingidos?

- Em sua opinião, quais conhecimentos químicos (conteúdos, habilidades e competências) são essenciais para os alunos do ensino médio? Por quê? 
- Relate uma aula de química, ministrada por você, que considerou boa. Por que você considera que essa foi uma boa aula?

- Relate uma aula de química, ministrada por você, que considerou ruim. Por que você considera que essa foi uma aula ruim?

\section{E - Relações com a sociedade}

1. O que você pensa sobre essa situação de aprendizagem (Situação de Aprendizagem 02: Estudo da síntese e da produção industrial da amônia a partir dos gases nitrogênio e hidrogênio) proposta pelo Caderno do Aluno?

2. Você já fez essas atividades em sala de aula conforme a orientação descrita no Caderno do Professor? Por quê?

3. Como você desenvolveu/conduziu essas atividades? Por quê? Quais modificações fez nela? Por quê?

4. Qual o seu principal objetivo ao abordar essa questão? 


\section{SITUAÇÂO DE APRENDIZAGEM 2 \\ ESTUDO DA SÍNTESE E DA PRODUÇÃO INDUSTRIAL DA AMÔNIA A PARTIR DOS GASES NITROGÊNIO E HIDROGÊNIO}

Nesta Situaçáo de Aprendizagem você vai estudar a importância do controle das condiçōes externas - pressáo e temperatura - em uma transformaçáo química para que ela seja economicamente viável. Para tanto, será apresentado o processo de obtençáo industrial da amônia desenvolvido por Haber na Alemanha, pouco antes do início da I Guerra Mundial. Esse estudo ainda vai permitir reflexóes sobre as influências das necessidades sociais, políticas e econômicas vigentes no desenvolvimento científico e tecnológico.

\section{Leitura e Análise de Texto}

\section{Produçáo industrial da amônia pelo processo Haber-Bosch - Parte I}

Hebe Ribeiro da Cruz Peixoto e Maria Fernanda Penteado Lamas

Desde o fim do século XVIII já se sabia que a amônia é formada a partir dos gases hidrogênio e nitrogênio na proporçáo de 3:1 e que podia ser obtida pela reação representada por

$$
\mathrm{N}_{2}(\mathrm{~g})+3 \mathrm{H}_{2}(\mathrm{~g}) \longrightarrow 2 \mathrm{NH}_{3}(\mathrm{~g})
$$

$\mathrm{Na}$ Europa do início do século XX, a amônia era matéria-prima na fabricaçáo de compostos nitrogenados, indispensáveis para que a produçáo agrícola fosse suficiente para alimentar a todos. Compostos nitrogenados também eram usados na indústria bélica. Esses compostos eram obtidos a partir do salitre $\left(\mathrm{NaNO}_{3}\right)$ proveniente de minas do Chile. Em 1900, o Chile exportou 1 milháo de toneladas de salitre, das quais 1/3 foi destinado à Alemanha. Alguns anos mais tarde, a exportaçăo anual do Chile ultrapassou 2,5 milhóes de toneladas. Além do problema do Chile poder fixar os preços do salitre, havia o perigo da exaustáo de suas minas e, em decorrência, haveria o declínio das exportaçóes e a fome. Vários países europeus buscaram desenvolver métodos para sintetizar compostos nitrogenados a partir do gás nitrogênio, abundante na atmosfera. Alguns processos foram desenvolvidos, porém consumiam muita energia e produziam pouca amônia. A Alemanha também estava empenhada em desenvolver um método de obtençáo de amônia que usasse como matéria-prima o nitrogênio do ar. Isso lhe garantiria autonomia na obtençáo dessa substância, autonomia crucial se levarmos em conta o momento histórico pelo qual passava a Europa: vésperas da I Guerra Mundial.

Já se sabia que a síntese da amônia aparentemente não se completava, pois, empregando-se quantidades estequiométricas de hidrogênio e de nitrogênio, havia um momento em que a quantidade de amônia formada parecia ter alcançado o limite máximo. Alcançado esse limite, se a temperatura e a pressáo permanecessem constantes e o sistema fosse mantido fechado, junto à amônia formada coexistiria uma certa quantidade dos gases nitrogênio e hidrogênio que, aparentemente, náo reagiria. Ao limite máximo de produto formado se dá o nome de "extensão da transformação química".

Elaborado especialmente para o Sáo Paulo faz escola.

\section{Questóes para análise do texto}

1. Na tabela é apresentado um exemplo de quantidades envolvidas na síntese da amônia a partir dos gases hidrogênio e nitrogênio realizada em sistema fechado, em uma determinada condiçáo 
de pressão e de temperatura. Lembrando que a equação balanceada que representa a síntese da amônia é $\mathrm{N}_{2}(\mathrm{~g})+3 \mathrm{H}_{2}(\mathrm{~g}) \rightleftharpoons 2 \mathrm{NH}_{3}(\mathrm{~g})$, faça uma previsāo teórica de quanta amônia deveria ser formada com base na equaçăo balanceada e complete a tabela.

\begin{tabular}{|c|c|c|c|c|c|}
\hline \multicolumn{1}{|c|}{} & \multicolumn{2}{|c|}{ Estado inicial } & \multicolumn{3}{c|}{ Estado final } \\
\cline { 2 - 6 } & \multicolumn{2}{|c|}{ Reagentes (mol) } & $\begin{array}{c}\text { Produto } \\
\text { formado (mol) }\end{array}$ & \multicolumn{2}{c|}{$\begin{array}{c}\text { Reagentes náo } \\
\text { transformados (mol) }\end{array}$} \\
\hline & $\mathbf{N}_{2}$ & $\mathbf{H}_{2}$ & $\mathbf{N H}_{3}$ & $\mathbf{N}_{2}$ & $\mathbf{H}_{2}$ \\
\hline $\begin{array}{c}\text { Previsão teórica } \\
\text { (estequiométrica) }\end{array}$ & 100,00 & 300,00 & & 0,00 & 0,00 \\
\hline Realidade & 100,00 & 300,00 & 135,00 & 32,50 & 97,50 \\
\hline
\end{tabular}

Tabela que apresenta as previsóes teóricas de produtos (de acordo com a estequiometria da transformaçáo química) e as quantidades obtidas experimentalmente a uma determinada condiçáo de pressáo e de temperatura.

Adaptada de: GEPEQ - Grupo de Pesquisa em Educaçáo Química (org.). Interaçóes e transformaçôes. Química para o Ensino Médio. Livro do Aluno. Reelaborando conceitos sobre transformaçóes químicas: cinética e equilíbrio. Săo Paulo: Edusp, 1995, v. II. p. 25.

2. Observe o que ocorreu na realidade: formou-se toda a amônia que se esperava de acordo com a previsão teórica?

3. Que gases estáo presentes no sistema depois da transformação química ter atingido seu limite máximo, sua extensão máxima?

\section{Saiba mais}

Em um sistema fechado, a uma determinada condiçăo de pressáo e de temperatura, e colocando-se quantidades estequiométricas de reagentes, podem ocorrer transformaçôes químicas, como a de síntese da amônia a partir dos gases nitrogênio e hidrogênio, que atingem uma extensão máxima onde coexistem reagentes e produtos. Essas quantidades não se modificam ao ser mantidas as condiçōes de pressão e de temperatura e se o sistema for mantido fechado. O rendimento obtido nesses tipos de transformaçăo química é menor que o previsto teoricamente, ou seja, é menor que o calculado pela estequiometria da reaçáo. Diz-se que essas são transformaçôes que entraram em um estado de equilíbrio químico. 
1. Na reaçấo de combustáo de certa quantidade de álcool etílico (etanol), a previsão teórica da quantidade de produtos formados é confirmada na prática. Pode-se dizer que essa é uma transformaçấo química que entra em equilíbrio químico? Explique.

2. A seguir são apresentados dados hipotéticos (obtidos em determinadas pressão e temperatura) relativos às quantidades de produtos formados nas transformaçōes químicas da combustão completa do carváo e da formaçáo do tetróxido de dinitrogênio. As medidas foram colhidas até que as quantidades de produtos e de reagentes não se alterassem mais.

Combustáo completa do carvấo: $1 \mathrm{C}(\mathrm{s})+1 \mathrm{O}_{2}(\mathrm{~g}) \rightarrow 1 \mathrm{CO}_{2}(\mathrm{~g})$

Formação do tetróxido de dinitrogênio: $2 \mathrm{NO}_{2}(\mathrm{~g}) \rightleftharpoons \mathrm{N}_{2} \mathrm{O}_{4}(\mathrm{~g})$

\begin{tabular}{|c|c|c|c|c|c|c|c|c|}
\hline \multirow{3}{*}{$\begin{array}{c}\text { Transformaçáo } \\
\text { Combustáo } \\
\text { completa do } \\
\text { carváo }\end{array}$} & \multicolumn{4}{|c|}{ Previsão teórica (estequiométrica) } & \multicolumn{4}{|c|}{ Realidade } \\
\hline & \multicolumn{2}{|c|}{$\begin{array}{l}\text { Reagentes } \\
\text { (mol) }\end{array}$} & \multirow{2}{*}{$\begin{array}{l}\text { Produtos } \\
\text { (mol) }\end{array}$} & \multirow{2}{*}{$\begin{array}{c}\text { Reagentes náo } \\
\text { transformados }\end{array}$} & \multicolumn{2}{|c|}{$\begin{array}{c}\text { Reagentes } \\
(\mathrm{mol})\end{array}$} & \multirow{2}{*}{$\begin{array}{c}\text { Produtos } \\
\text { (mol) }\end{array}$} & \multirow{2}{*}{$\begin{array}{c}\text { Reagentes náo } \\
\text { transformados } \\
\text { (mol) }\end{array}$} \\
\hline & $10 \mathrm{C}(\mathrm{s})$ & $10 \mathrm{O}_{2}(\mathrm{~g})$ & & & $10 \mathrm{C}(\mathrm{g})$ & $10 \mathrm{O}_{2}(\mathrm{~g})$ & & \\
\hline $\begin{array}{l}\text { Formaçáo do } \\
\text { tetróxido de } \\
\text { dinitrogênio }\end{array}$ & \multicolumn{2}{|c|}{$10 \mathrm{NO}_{2}(\mathrm{~g})$} & $5 \mathrm{~N}_{2} \mathrm{O}_{4}(\mathrm{~g})$ & 0 & \multicolumn{2}{|c|}{$10 \mathrm{NO}_{2}(\mathrm{~g})$} & $3 \mathrm{~N}_{2} \mathrm{O}_{4}(\mathrm{~g})$ & $4 \mathrm{NO}_{2}(\mathrm{~g})$ \\
\hline
\end{tabular}

Analise os dados da tabela e responda: alguma dessas reaçóes atingiu o equilíbrio químico? Justifique. 


\section{Leitura e Análise de Texto}

\section{Produçáo industrial da amônia pelo processo Haber-Bosch - Parte II}

Hebe Ribeiro da Cruz Peixoto e Maria Fernanda Penteado Lamas

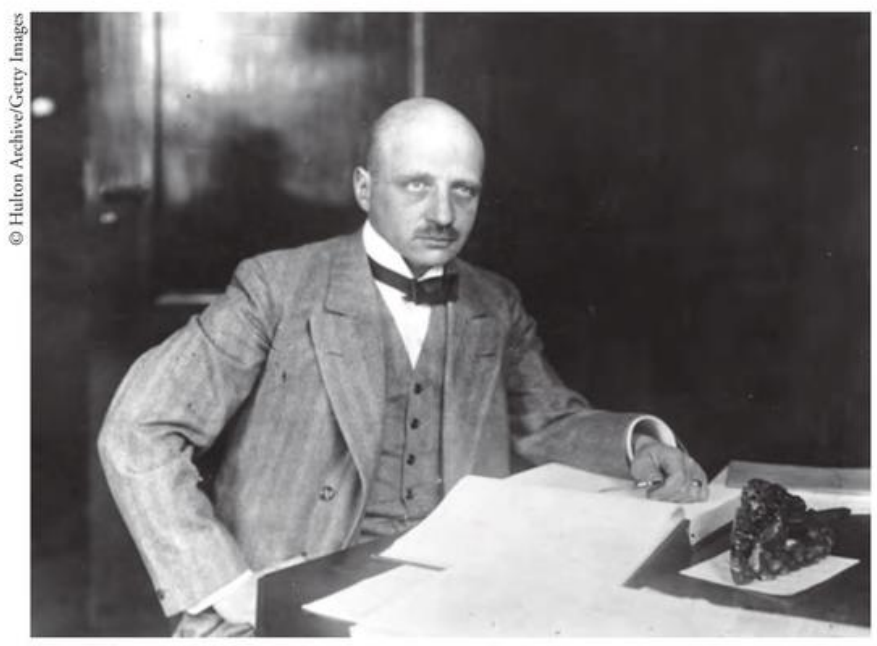

Fritz Haber (1868-1934), um químico nascido na Polônia, estudou e trabalhou na Alemanha onde buscou desenvolver um processo de obtenção do gás amônia, a partir dos gases nitrogênio e hidrogênio. $O$ processo deveria permitir a produçáo de amônia em escala industrial e ser economicamente viável. Haber fez reagir hidrogênio e nitrogênio gasosos na proporção de 3:1 a diferentes temperaturas. Constatou que:

Fritz Haber

- Em temperaturas mais baixas, a transformaçáo ocorria mais lentamente, mas se obtinham maiores quantidades de amônia. Por exemplo, a cerca de $100^{\circ} \mathrm{C}$ (temperatura considerada baixa para o processo da síntese da amônia), obtinha-se uma quantidade apreciável de amônia, mas o tempo gasto era muito grande. Dessa maneira, a obtençăo da amônia em escala industrial tornava-se economicamente inviável.

- Em temperaturas mais altas, a transformaçáo ocorria mais rapidamente, mas se obtinha menos amônia. Por exemplo, a temperaturas próximas a $1000^{\circ} \mathrm{C}$, obtinha-se pouca amônia, apesar da transformaçăo se dar mais rapidamente que a $100^{\circ} \mathrm{C}$. O processo também era economicamente inviável, pois se gastava muito combustível para aquecer os reatores e, apesar da transformaçăo se dar mais rapidamente, a quantidade de amônia obtida năo compensava o gasto envolvido em sua produçăo.

Haber resolveu testar essa reaçáo a pressōes mais elevadas. Testou então diferentes combinaçōes de pressão e de temperatura buscando condiçóes em que a síntese da amônia fosse economicamente viável, ou seja, que ocorresse em um tempo razoavelmente curto e que a extensão fosse grande o suficiente para compensar os custos envolvidos.

Para tanto, fixou diversas temperaturas e variou, para cada uma delas, as pressōes. Depois, fixou diversas pressōes e variou as temperaturas. Considerou as sínteses terminadas quando a quantidade de amônia formada se manteve constante. Então obteve dados como os apresentados na tabela a seguir. 


\begin{tabular}{|c|c|c|c|c|}
\hline \multicolumn{5}{|c|}{ Porcentagens de amônia formada a partir de misturas 3:1 de $\mathrm{H}_{2}: \mathrm{N}_{2}$} \\
\hline $\begin{array}{c}\text { Pressáo } \\
(\mathbf{a t m})\end{array}$ & $\mathbf{2 0 0}$ & $\mathbf{3 0 0}$ & $\mathbf{4 0 0}$ & $\mathbf{5 0 0}$ \\
\hline $\begin{array}{c}\text { Temperatura } \\
\left({ }^{\circ} \mathbf{C}\right)\end{array}$ & 38,7 & 47,8 & 58,9 & 60,6 \\
\hline $\mathbf{4 0 0}$ & 27,4 & 35,9 & 42,9 & 48,8 \\
\hline $\mathbf{4 5 0}$ & 18,9 & 26,0 & 32,2 & 37,8 \\
\hline $\mathbf{5 0 0}$ & 12,8 & 18,4 & 23,5 & 28,3 \\
\hline $\mathbf{5 5 0}$ & 8,80 & 13,0 & 17,0 & 20,8 \\
\hline $\mathbf{6 0 0}$ & & & \\
\hline
\end{tabular}

Adaptada de: GEPEQ - Grupo de Pesquisa em Educaçáo Química (org.). Interạ̧óes e transformaçôes. Química para o Ensino Médio. Livro do aluno. Reelaborando conceitos sobre transformaçóes químicas: cinética e equilíbrio. São Paulo: Edusp, 1995, v. II. p. 26.

Elaborado esvecialmente vara o São Paulo faz escola.

\section{Questões para análise do texto}

1. Observe essa tabela e avalie qual seria a melhor condiçáo de pressão e de temperatura para se obter a maior quantidade possível de amônia.

2. O que você faria para obter mais amônia (obter um melhor rendimento) a $400^{\circ} \mathrm{C}$ ? $\mathrm{E}$ a $500^{\circ} \mathrm{C}$ ?

3. Complete: "Ao se aumentar a pressão, o rendimento da reaçáo de síntese da amônia”. 
4. Qual é o rendimento da síntese da amônia a $400^{\circ} \mathrm{C}$ e 500 atm de pressão? E qual é o rendimento da síntese da amônia a $600{ }^{\circ} \mathrm{C}$ e 500 atm de pressăo?

5. Complete: "Ao se aumentar a temperatura, o rendimento da reação de síntese da amônia".

6. Explique por que é importante escolher e controlar as condiçôes de pressão e de temperatura na produçấo da amônia pelo processo Haber.

Como já tínhamos concluído, em um sistema fechado, quando, a uma determinada pressão $\mathrm{e}$ a uma determinada temperatura, uma transformaçāo atinge sua extensão máxima, isto é, quando coexistem reagentes e produtos e suas quantidades năo se modificam, diz-se que a transformaçấo química atingiu o estado de equilíbrio químico.

Ao se estudar a síntese do gás amônia a partir dos gases hidrogênio e nitrogênio, pôde-se perceber que o aumento da temperatura provoca uma diminuiçáo na extensão da reaçáo, ou seja, a quantidade de amônia formada diminui. Observou-se também que aumentos na pressão do sistema favorecem a formaçáo da amônia

\section{LIÇĀO DE CASA}

Vamos analisar mais uma situaçăo: considere que um analista químico resolveu repetir o experimento de Haber. Para tanto, colocou em um frasco gás hidrogênio e gás nitrogênio na proporção de 3:1 (proporção estequiométrica) a $400{ }^{\circ} \mathrm{C}$ e a uma pressão de $200 \mathrm{~atm}$. Então começou a formar-se amônia. Esperou até que a quantidade de amônia năo se alterasse mais com o passar do tempo, ou seja, até que o equilíbrio químico fosse alcançado. 
1. Que gases estâo contidos nesse frasco? Justifique.

Depois, o químico submeteu o mesmo frasco em que obteve a amônia à temperatura de $450^{\circ} \mathrm{C}$, mantendo a pressáo de $200 \mathrm{~atm}$. Esperou até que a quantidade de amônia formada náo se alterasse mais com o passar do tempo.

2. Que gases estáo contidos nesse frasco? Explique sua resposta.

3. O que deve ter acontecido com a quantidade de amônia nessa temperatura após o sistema ter alcançado o novo equilíbrio químico: aumentou ou diminuiu? Explique.

Depois dessa etapa, o químico submeteu o mesmo frasco a uma diminuição de temperatura, até que o sistema alcançasse novamente $400^{\circ} \mathrm{C}$, mantendo a pressão de $200 \mathrm{~atm}$. Esperou até que a quantidade de gás amônia náo se alterasse mais com o passar do tempo.

4. O que você supóe que tenha acontecido com a quantidade de gás amônia que coexiste com os gases nitrogênio e hidrogênio em equilíbrio químico? 


\section{Leitura e Análise de Texto}

\section{Produçáo industrial da amônia pelo processo Haber-Bosch - Parte III}

Hebe Ribeiro da Cruz Peixoto e Maria Fernanda Penteado Lamas

Em busca de rapidez no processo de produçáo da amônia, Haber resolveu testar as reaçôes em presença de diferentes catalisadores. Naquela época já se sabia que catalisadores são substâncias que modificam o tempo de transformaçôes químicas. Fez entāo reagir hidrogênio e nitrogênio sobre as superfícies de diferentes metais e procurou verificar como eles afetavam a rapidez de obtenção da amônia. Observou que, quando a transformaçáo ocorria sobre ferro aquecido, o equilíbrio químico era atingido mais rapidamente.

Atençáo: catalisadores modificam a rapidez de transformaçốes químicas, porém nấo influem na extensáo delas, ou seja, a quantidade máxima de produtos obtidos não será alterada. No caso de transformaçóes que entram em equilíbrio químico, este será alcançado mais rapidamente.

Mais tarde, Carl Bosch aperfeiçoou o processo Haber, que ficou conhecido como processo Haber-Bosch, e até hoje esse método é utilizado na obtenção industrial da amônia.

Enfim, a obtençáo industrial da amônia mostra a importância de serem compreendidos os fatores que podem influenciar a rapidez e a extensão com que uma transformaçấo química acontece. A elevação da temperatura aumenta a rapidez com que a reaçáo atinge seu limite (o equilíbrio químico), depois do qual a quantidade de amônia não se altera mais. De outro modo, o aumento da temperatura diminui a extensáo da transformação dessa síntese, isto é, uma menor quantidade de amônia é formada. Em razão desses aspectos, é necessário escolher valores de pressão e de temperatura que permitam que se obtenha a maior quantidade de amônia possível, no menor tempo possível, para que o processo seja economicamente viável.

Como se faz isso? É necessário saber analisar e calcular os diferentes rendimentos, nas variadas condiçóes de temperatura e de pressáo, e verificar, para cada uma delas, quanta energia foi utilizada e qual foi o custo envolvido.

Em 2004, Paul Chirik coordenou uma equipe de pesquisadores da Universidade Cornell (Estados Unidos) que conseguiu quebrar as ligaçôes entre os átomos de uma molécula de gás nitrogênio, adicionando gás hidrogênio e obtendo gás amoníaco, sem a necessidade de altas temperaturas e de altas pressóes. Para tanto, utilizou uma solução contendo zircônio. A conversão foi feita a $85^{\circ} \mathrm{C}$. O foco da busca agora é encontrar um catalisador para essa reaçáo de modo que ela possa ser utilizada em escala industrial. 
Registre aqui o que você aprendeu sobre a síntese da amônia pelo processo Haber-Bosch. 


\section{PESQUISA EM GRUPO}

Esta pesquisa tem por objetivo explicitar a importância do nitrogênio nos sistemas natural e produtivo. Para tanto, cada grupo pode buscar informaçôes sobre um ou mais itens sugeridos a seguir, ou mesmo sobre outros itens de acordo com a orientação de seu professor. Sugere-se busca em livros didáticos de Biologia, em jornais, revistas e na internet. Tente organizar sua pesquisa levando em consideraçâo as orientaçôes abaixo. Prepare um resumo para apresentar a seus colegas.

- Busque exemplos que mostrem a importância do ciclo do nitrogênio.

- Relacione o ciclo do nitrogênio com a síntese de proteínas, assim como a importância dessa síntese para a vida como a conhecemos.

- Procure informaçôes sobre o uso de fertilizantes à base de nitrogênio.

- Pesquise informaçôes sobre as reaçōes de obtençáo de algumas substâncias nitrogenadas fabricadas a partir da amônia e presentes em fertilizantes, tais como a ureia $\left(\left(\mathrm{NH}_{2}\right)_{2} \mathrm{CO}\right)$, o nitrato de amônio $\left(\mathrm{NH}_{4} \mathrm{NO}_{3}\right)$, o sulfato de amônio $\left(\left(\mathrm{NH}_{4}\right)_{2} \mathrm{SO}_{4}\right)$, o cloreto de amônio $\left(\mathrm{NH}_{4} \mathrm{Cl}\right)$, o fosfato de cálcio e amônio $\left(\mathrm{CaNH}_{4} \mathrm{PO}_{4}\right)$ e o nitrato de amônio e cálcio $\left(\mathrm{CaNH}_{4}\left(\mathrm{NO}_{3}\right)_{3}\right)^{4}$.

- Busque informaçóes sobre reaçóes que descrevem o uso da amônia como matéria-prima usada na produção de ácido nítrico e da barrilha (carbonato de sódio).

- Pesquise sobre os usos do ácido nítrico como matéria-prima. 
Anote também as informaçôes pesquisadas por seus colegas.

APRENDENDO A APRENDER

Ao visitar um supermercado ou uma loja que venda produtos agrícolas, observe rótulos de um fertilizante do tipo NPK. Procure reconhecer quais substâncias estấo presentes nesses fertilizantes e recorde-se de como o nitrogênio é obtido. 
Gostaria também da sua opinião sobre uma atividade (Atividade A), elaborada com base nessa Situação de Aprendizagem e em outros materiais.

5. Na parte 01, é proposto um levantamento de conhecimentos prévios dos alunos. Depois, leitura de texto e trabalho com perguntas do Caderno do Aluno envolvendo o equilíbrio químico. Em seguida, há uma proposta de discussão com a turma (item IV). O que você pensa sobre essa proposta? Explique. (Você realizaria essa atividade em sala de aula? Por quê? De que outro modo você a faria?)

6. Com relação à segunda parte, qual a sua opinião sobre o item III $c$ proposta? Explique. (Você realizaria essa atividade em sala de aula? Por quê? De que outro modo você a faria?)

7. Na parte final, há indicações para o professor mediar algumas discussões. $\bigcirc$ que você pensa sobre as propostas dos itens $c$ ao $f$ ? Explique. (Você realizaria essa atividade em sala de aula? Por quê? De que outro modo você a faria?) 


\section{Atividade A}

\section{Parte 1 - Descrição resumida das atividades}

I) Conversa inicial

a) Apresentar o trecho inicial do livro de Vaclav Smil, Enriching the Earth.

"Qual seria a mais importante invenção técnica do século XX? Aeroplanos, energia nuclear, voo espacial, televisão e computadores estão entre as respostas mais comuns. Porém, nenhuma destas invenções teve a fundamental importância da síntese industrial da amônia a partir de seus elementos."

b) Perguntar aos estudantes: por que o autor tem essa opinião a respeito da síntese da amônia?

c) Deixar os estudantes exporem suas opiniões e apontar que vamos responder isso ao longo das próximas atividades.

II) Leitura do texto "Produção industrial da amônia pelo processo Haber-Bosch" - Parte I

\section{Produção industrial da amônia pelo processo Haber-Bosch - Parte I}

\section{Hebe Ribeiro da Cruz Peixoto e Maria Fernanda Penteado Lamas}

Desde o fim do século XVIII já se sabia que a amônia é formada a partir dos gases hidrogênio e nitrogênio na proporção de 3:1 e que podia ser obtida pela reação representada por:

$$
\mathrm{N}_{2}(\mathrm{~g})+3 \mathrm{H}_{2}(\mathrm{~g})=2 \mathrm{NH}_{3}(\mathrm{~g})
$$

Na Europa do início do século $X X$, a amônia era matéria-prima na fabricação de compostos nitrogenados, indispensáveis para que a produção agrícola fosse suficiente para alimentar a todos. Compostos nitrogenados também eram usados na indústria bélica. Esses compostos eram obtidos a partir do salitre (NaNO3) proveniente de minas do Chile. Em 1900, o Chile exportou 1 milhão de toneladas de salitre, das quais $1 / 3$ foi destinado à Alemanha. Alguns anos mais tarde, a exportação anual do Chile ultrapassou 2,5 milhões de toneladas. Além do problema do Chile poder fixar os preços do salitre, havia o perigo da exaustão de suas minas e, em decorrência, haveria o declínio das exportações e a fome. Vários países europeus buscaram desenvolver métodos para sintetizar compostos nitrogenados a partir do gás nitrogênio, abundante na atmosfera. Alguns processos foram desenvolvidos, porém consumiam muita energia e produziam pouca amônia. A Alemanha também estava empenhada em desenvolver um método de obtenção de amônia que usasse como matéria-prima o nitrogênio do ar. Isso lhe garantiria autonomia na obtenção dessa substância, autonomia crucial se levarmos em conta o momento histórico pelo qual passava a Europa: vésperas da I Guerra Mundial.

Já se sabia que a síntese da amônia aparentemente não se completava, pois, empregando-se quantidades estequiométricas de hidrogênio e de nitrogênio, havia um momento em que a quantidade de amônia formada parecia ter alcançado o limite máximo. Alcançado esse limite, se a temperatura e a pressão permanecessem constantes e o sistema fosse mantido fechado, junto à amônia formada coexistiria uma certa quantidade dos gases nitrogênio e hidrogênio que, aparentemente, não reagiria. Ao limite máximo de produto formado se dá o nome de "extensão da transformação química". 
a) Ler o texto com os estudantes

b) Tirar as dúvidas sobre o texto.

III) Questionário

- Na tabela é apresentado um exemplo de quantidades envolvidas na síntese da amônia a partir dos gases hidrogênio e nitrogênio realizada em sistema fechado, em uma determinada condição de pressão e de temperatura. Lembrando que a equação balanceada que representa a síntese da amônia é $\mathrm{N}_{2}(\mathrm{~g})+3 \mathrm{H}_{2}(\mathrm{~g})=2 \mathrm{NH}_{3}(\mathrm{~g})$, faça uma previsão teórica de quanta amônia deveria ser formada com base na equação balanceada e complete a tabela.

\begin{tabular}{|c|c|c|c|c|c|}
\hline & \multirow{2}{*}{\multicolumn{2}{|c|}{$\begin{array}{c}\text { Estado inicial } \\
\text { Reagentes (mol) }\end{array}$}} & \multicolumn{3}{|c|}{ Estado final } \\
\hline & & & \multirow{2}{*}{$\begin{array}{c}\begin{array}{c}\text { Produto } \\
\text { formado (mol) }\end{array} \\
\mathrm{NH}_{3}\end{array}$} & \multicolumn{2}{|c|}{$\begin{array}{c}\text { Reagentes náo } \\
\text { transformados }(\mathrm{mol})\end{array}$} \\
\hline & $\mathrm{N}_{2}$ & $\mathrm{H}_{2}$ & & $\mathrm{~N}_{2}$ & $\mathrm{H}_{2}$ \\
\hline $\begin{array}{l}\text { Previsáo teórica } \\
\text { (estequiométrica) }\end{array}$ & 100,00 & 300,00 & & 0,00 & 0,00 \\
\hline Realidade & 100,00 & 300,00 & 135,00 & 32,50 & 97,50 \\
\hline
\end{tabular}

- Observe o que ocorreu na realidade: formou-se toda a amônia que se esperava de acordo com a previsão teórica?

- Que gases estão presentes nos sistemas depois da transformação química ter atingido o seu limite máximo, sua extensão máxima?

a) Pedir aos alunos que respondam as questões anteriores.

b) Resolver e comentar com os alunos as questões e iniciar a discussão introdutória sobre equilíbrio químico.

IV - Discussão com a turma.

a) Por que havia um grande interesse da Alemanha na produção da amônia no início do século $X X$ ?

b) Fornecer aos alunos mais informações sobre o contexto político e econômico da Europa da época e discutir as demandas sociais, políticas e econômicas envolvidas na obtenção da amônia.

\section{Parte 2 - Descriç̃o resumida das atividades}

I) Retomando as ideias.

a) Comentar novamente a importância da produção da amônia para a Alemanha e os problemas para obtê-la, enfatizando a questão de transformações químicas que não se completam de acordo com a previsão estequiométrica. 
II) Leitura do texto "Produção industrial da amônia pelo processo Haber-Bosch" - Parte II

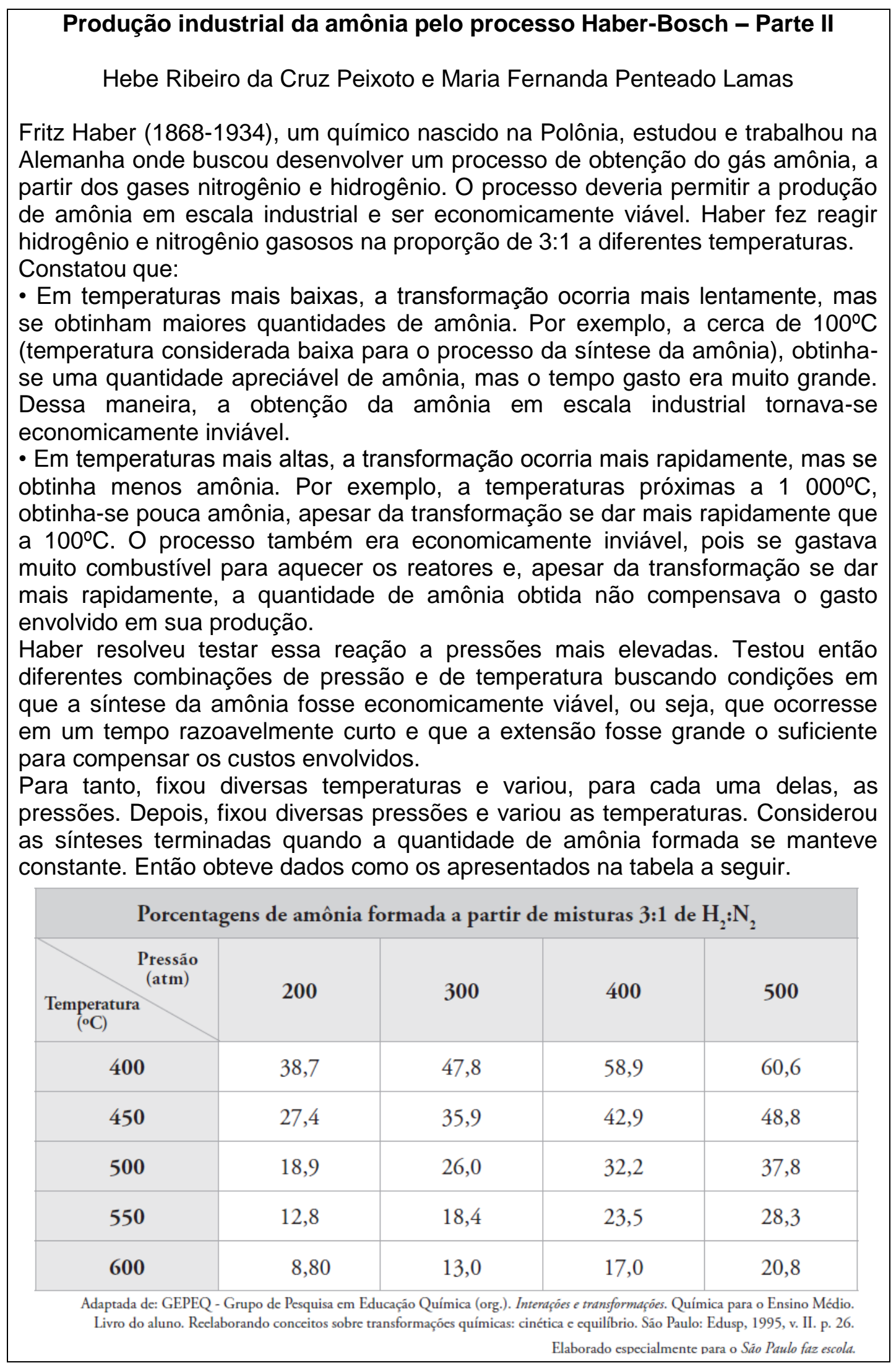

a) Ler o texto com os estudantes. 
b) Tirar as dúvidas sobre o texto.

III) Questionário

- Observe essa tabela e avalie qual seria a melhor condição de pressão e de temperatura para se obter a maior quantidade possível de amônia.

- O que você faria para obter mais amônia (obter um melhor rendimento) a $400^{\circ} \mathrm{C}$ ? E a $500^{\circ} \mathrm{C}$ ?

- Complete: "Ao se aumentar a pressão, o rendimento da reação de síntese da amônia".

- Qual é o rendimento da síntese da amônia a 400ㄷ e $500 \mathrm{~atm}$ de pressão? E qual é o rendimento da síntese da amônia a $600^{\circ} \mathrm{C}$ e 500atm de pressão?

- Complete: "Ao se aumentar a temperatura, o rendimento da reação de síntese da amônia".

- Explique por que é importante escolher e controlar as condições de pressão e de temperatura na produção da amônia pelo processo Haber.

a) Pedir aos alunos que respondam as questões anteriores.

b) Fazer com os alunos as questões e apontar a importância das condições de pressão e temperatura para tornar o processo economicamente viável.

c) Comentar com os estudantes sobre a importância de Friedrich Kirchenbauer, metalurgista que desenvolveu recipientes e métodos para se obter uma pressão mais alta do que comumente se obtinha na época. Discutir com os alunos a interdependência entre ciência e tecnologia.

Observação: Nesse item, de modo alternativo, dependendo da característica da turma de estudantes, pode-se considerar com eles a relação entre pesquisa básica e aplicada, com base na discussão da seguinte frase de Roald Hoffman, ganhador do prêmio Nobel de química de 1981, sobre a síntese proposta por Haber: "Talvez nunca antes houvesse um processo laboratorial para um processo industrial sido desenvolvido tão completamente em um ambiente acadêmico." (Hoffman, R. O mesmo e o não mesmo, página 220.)

\section{Parte 3 - Descricão resumida das atividades}

I) Leitura do texto "Produção industrial da amônia pelo processo Haber-Bosch" - Parte III

\section{Produção industrial da amônia pelo processo Haber-Bosch - Parte III}

\section{Hebe Ribeiro da Cruz Peixoto e Maria Fernanda Penteado Lamas}

Em busca de rapidez no processo de produção da amônia, Haber resolveu testar as reações em presença de diferentes catalisadores. Naquela época já se sabia que catalisadores são substâncias que modificam o tempo de transformações químicas. Fez então reagir hidrogênio e nitrogênio sobre as superfícies de diferentes metais e procurou verificar como eles afetavam a rapidez de obtenção da amônia. Observou que, quando a transformação ocorria sobre ferro aquecido, o equilíbrio químico era atingido mais rapidamente.

Atenção: catalisadores modificam a rapidez de transformações químicas, porém não influem na extensão delas, ou seja, a quantidade máxima de produtos obtidos não será alterada. No caso de transformações que entram em equilíbrio químico, este será alcançado mais rapidamente.

Mais tarde, Carl Bosch aperfeiçoou o processo Haber, que ficou conhecido como processo Haber-Bosch, e até hoje esse método é utilizado na obtenção industrial da amônia. 
Enfim, a obtenção industrial da amônia mostra a importância de serem compreendidos os fatores que podem influenciar a rapidez e a extensão com que uma transformação química acontece. A elevação da temperatura aumenta a rapidez com que a reação atinge seu limite (o equilíbrio químico), depois do qual a quantidade de amônia não se altera mais. De outro modo, o aumento da temperatura diminui a extensão da transformação dessa síntese, isto é, uma menor quantidade de amônia é formada. Em razão desses aspectos, é necessário escolher valores de pressão e de temperatura que permitam que se obtenha a maior quantidade de amônia possível, no menor tempo possível, para que o processo seja economicamente viável.

Como se faz isso? É necessário saber analisar e calcular os diferentes rendimentos, nas variadas condições de temperatura e de pressão, e verificar, para cada uma delas, quanta energia foi utilizada e qual foi o custo envolvido.

Em 2004, Paul Chirik coordenou uma equipe de pesquisadores da Universidade Cornell (Estados Unidos) que conseguiu quebrar as ligações entre os átomos de uma molécula de gás nitrogênio, adicionando gás hidrogênio e obtendo gás amoníaco, sem a necessidade de altas temperaturas e de altas pressões. Para tanto, utilizou uma solução contendo zircônio. A conversão foi feita a $85 \stackrel{\circ}{\circ}$. $\mathrm{O}$ foco da busca agora é encontrar um catalisador para essa reação de modo que ela possa ser utilizada em escala industrial.

Elaborado especialmente para o São Paulo faz escola.

a) Ler o texto com os estudantes e tirar as dúvidas sobre o texto.

b) Retomar as ideias sobre equilíbrio químico e fatores que influenciam a rapidez e extensão de uma reação.

II - Conversa final

a) Revisar questões importantes envolvendo equilíbrio químico.

b) Retomar a Conversa Inicial.

c) Ler com os estudantes trechos da notícia do site http://www.brasil247.com/pt/247/minas247/120871/Petrobr\%C3\%A1s-quer-implantarf\%C3\%A1brica-de-am\%C3\%B4nia-em-Minas.htm (modificada)

\section{Petrobrás quer implantar fábrica de amônia em Minas}

14 de novembro de 2013 às 18:48

Agência Minas - O Governo de Minas e a Petrobras assinaram, nesta quinta-feira (14), o Protocolo de Intenções para implantação de uma fábrica de amônia, denominada, pela Petrobrás de projeto Unidade de Fertilizantes Nitrogenados- $\mathrm{V}$, no município de Uberaba, no Triângulo Mineiro. O protocolo de intenções também foi assinado pelo Instituto de Desenvolvimento Integrado (Indi), órgão vinculado à Secretaria de Desenvolvimento Econômico (Sede). O projeto da UFN-V está inserido no Plano de Negócios da estatal.

A UFN-V possui uma capacidade projetada de, aproximadamente, 1,5 mil toneladas por dia de amônia, o que corresponde a 519 mil toneladas por ano. Projeta-se também a venda de aproximadamente 277 mil t toneladas por ano de dióxido de carbono $\left(\mathrm{CO}_{2}\right)$. O investimento será de cerca de $R \$ 2,3$ bilhões e o início de operação está previsto para novembro de 2016.

No segmento de fertilizantes, a Petrobras está investindo em novas unidades, a fim de acompanhar o crescimento do mercado brasileiro, cuja demanda tem sido maior do que a capacidade de oferta da produção nacional. Para a implantação da fábrica de amônia, o Governo de Minas disponibilizou terreno de 1 milhão de 
metros quadrados no Distrito Industrial III, em Uberaba.

Além de desenvolver a região do Triângulo Mineiro, a implantação da fábrica de amônia em Uberaba reduzirá a dependência do país da matéria-prima para a fabricação de fertilizantes, importante insumo do agronegócio. Em 2012, 61\% da demanda por amônia no Brasil foi atendida pelo mercado externo (Fonte: ANDA, 2013).

Atualmente, grande parte da amônia consumida na região é importada via porto de Santos e transportada por carretas até a planta situada no Distrito Químico de Uberaba. Com a produção da matéria-prima em Uberaba, a expectativa é de que o segmento reduza os custos com transporte do material, possibilitando a redução de custos de produção. A produção de amônia no município também retirará das principais estradas, diariamente, cerca de 100 caminhões por dia transportando o produto, evitando acidentes ambientais e riscos para a população.

d) Apontar o uso da amônia como matéria-prima para a obtenção de vários materiais, principalmente para a agricultura moderna, bem como discutir a importância da autossuficiência na produção da substância.

e) Discutir problemas ambientais decorrentes da utilização intensiva de fertilizantes químicos, bem como o risco à saúde da população pelo uso dos agrotóxicos.

Adicionalmente, dependendo da discussão inicial, pode-se tratar as questões éticas envolvidas na síntese de uma substância química, visto que os produtos obtidos nas transformações podem também causar danos ao meio ambiente e/ou serem usados como armas químicas.

f) Explicitar a relação entre a química e a indústria, assim como os fatores ambientais e éticos decorrentes dessa relação. 


\section{F - Modelos e modelagem}

1. Na sua prática pedagógica, você aborda a questão dos modelos científicos? Por quê?

2. Descreva uma aula ou situação em que você trabalhou essa questão. Por que você a abordou desse modo?

3. Quando você aborda essa questão, quais são seus principais objetivos e suas prioridades? O que é importante que os alunos saibam em relação a esse tema?

Gostaria de saber sua opinião sobre uma outra proposta de atividade (Atividade

$B$ ) acerca do assunto ligações químicas, especificamente ligação iônica.

4. De modo geral, qual a sua opinião sobre essa proposta? Quais modificações faria nela e por quê?

5. Qual a sua opinião sobre a proposta da parte 1?

6. O que você pensa sobre o último ponto do item I (sobre o docente comentar o que é modelo e algumas de suas características)?

7. Qual a sua opinião sobre a discussão proposta ao final da parte 2? Você faria uma discussão como essa? Por quê? 


\section{Atividade B}

\section{Parte 1 - Modelos explicativos}

Discussão com o grupo de estudantes

- Os estudantes, individualmente, expressam suas ideias sobre o que é um modelo.

- Estudantes classificam alguns sistemas (veja abaixo) como sendo modelos ou não, justificando as escolhas.

\begin{tabular}{|c|c|c|c|}
\hline \multirow[t]{2}{*}{ Sistemas } & \multicolumn{2}{|c|}{ Modelos } & \multirow[t]{2}{*}{ Explicação } \\
\hline & SIM & NÃO & \\
\hline Fórmula química da água $\left(\mathrm{H}_{2} \mathrm{O}\right)$ & & & \\
\hline $\begin{array}{l}\text { Fenômeno de dissolução do permanganato de potássio em } \\
\text { água }\end{array}$ & & & \\
\hline Gráfico de velocidade em função do tempo & & & \\
\hline Мара & & & \\
\hline
\end{tabular}

- Os estudantes expõem suas ideias e justificativas.

- O professor introduz a noção de modelo com os alunos e apresenta algumas de suas características na química.

\section{Parte 2 - Elaboração de modelo}

- Os estudantes, em grupo, elaboram um modelo para explicar o funcionamento de uma cola de madeira e papel com secagem instantânea.

- Os grupos descrevem as etapas utilizadas para a realização da tarefa e justificam cada uma delas.

- Os grupos apresentam seus modelos e justificativas. Todos os participantes discutem se os modelos elaborados conseguiam explicar satisfatoriamente.

- O professor medeia uma discussão sobre os modelos com base nas seguintes questões:

a) Como os modelos são elaborados na ciência? Qual o papel dos cientistas nesse processo?

b) Quais as funções dos modelos na química?

\section{Parte 3 - Formacão de substâncias}

- Os estudantes realizam a queima de uma fita de magnésio e procuram explicar o fenômeno observado.

- O professor realiza discussão sobre as relações entre energia, estabilidade e ligação química.

\section{Parte 4 - Modelo para formação dos íons}

- Utilizando dados da primeira energia de ionização, os estudantes, em grupo, elaboram um modelo para explicar a formação dos íons sódio e cloreto.

\section{Parte 5 - Interacão dos íons}

- Os grupos propõem um modelo para o sistema sal de cozinha dissolvido em água e, depois, um modelo para esse sistema após a evaporação da água.

- O professor solicita que os grupos expressem seus modelos de vários modos: escrito, verbal, por meio de desenhos ou utilizando massa de modelar, palitos, etc.

- Os grupos justificam seus modelos e respondem questões sobre a relação entre energia e estabilidade. 


\section{Parte 6-Testando o modelo}

- Os grupos usam o modelo elaborado na atividade anterior para explicar a elevada temperatura de fusão do cloreto de sódio e de outros compostos.

- Os grupos que não conseguiram usar seus modelos para explicar a propriedade reformulam seus modelos e comparam-no com o anterior.

\section{Parte 7 - Atração entre os íons em rede}

- O professor fornece dados sobre a energia liberada na formação de um par de íons $\mathrm{Na}^{+}$ e $\mathrm{Cl}^{-}$e na formação de uma rede de íons

- Os grupos reformulam seus modelos a partir dos subsídios iniciais.

- Com o novo modelo os grupos procuram explicar novamente o alto ponto de fusão do cloreto de sódio.

- Os grupos apresentam seu modelo e os justificam perante os outros.

- A partir de uma discussão mediada pelo professor, os modelos são negociados visando um modelo consensual. A negociação obedece a determinados critérios, como a consistência com as evidências experimentais.

\section{Parte 08 - Apresentando o modelo científico}

- O professor retomou os modelos feitos pelos alunos e comenta sobre suas abrangências e limites.

- Foi apresentado para os alunos o modelo científico do $\mathrm{NaCl}$ (retículo cúbico).

- O professor comentou sobre força de atração eletrostática e abaixamento de energia na formação da ligação iônica. A seguir, apresentou exemplos de outras substâncias iônicas e ressaltou propriedades dos compostos iônicos.

\section{Parte 09 - Conclusão}

- O professor, por meio de diversos questionamentos, promove uma reflexão com os estudantes sobre as atividades realizadas.

- Nessa atividade final, o docente:

- retoma a definição de modelos e o motivo pelo qual eles foram desenvolvidos nas atividades;

- comenta os diversos tipos de modelos científicos;

- discute características dos modelos elaborados por eles;

- enfatiza a influência das concepções prévias dos estudantes na elaboração dos modelos e o fato de que uma mesma entidade pode ter mais de um modelo;

- retoma como os modelos são construídos na ciência e o papel dos cientistas no processo;

- aponta as semelhanças e diferenças entre as atividades realizadas e a construção de modelos na ciência. 
Antes de abordar o modelo de Dalton, o Caderno do Professor sugere a atividade denominada "Cena de um crime" (Situação de Aprendizagem 04: Modelo atômico de Dalton: ideias sobre a constituição e transformação da matéria: Atividade 01). Depois, o material recomenda uma discussão sobre modelos (Situação de Aprendizagem 04: Modelo atômico de Dalton: ideias sobre a constituição e transformação da matéria: Atividade 02.)

8. Você já fez essa atividade como ela é proposta no material? Por quê? Quais modificações fez (ou faria) nela?

9. Qual a sua opinião sobre essa atividade? 
estudantes devem identificar que o gás carbônico, entre os gases da atmosfera, é o que mais absorve as radiações eletromagnéticas e, por isso, é o principal responsável pelo efeito estufa. Quanto ao item d, espera-se que respondam que o aumento do efeito estufa pode causar o aquecimento global, e este pode provocar muitos problemas ambientais, como derretimento das calotas polares, mudanças climáticas, formação de áreas desérticas etc.

Na questão 1 da Folha de atividades 2 (CA, p. 33), sobre a chuva ácida, espera-se que sejam identificados os gases poluentes - dióxido de enxofre $\left(\mathrm{SO}_{2}\right)$ e os óxidos de nitrogênio - como os compostos que provocam a chuva ácida $\mathrm{e}$ que são provenientes da queima de combustíveis, principalmente os de origem fóssil. $\mathrm{Na}$ questão 2, espera-se que os alunos relacionem a chuva ácida à degradação do meio ambiente, provocando a morte de plantas e animais e também desgastando monumentos e construções. Na questão 3, por meio da análise da figura, os alunos devem perceber que os gases poluentes que escapam para a atmosfera estão sujeitos à ação dos ventos e, portanto, podem ser transportados para outras regiões, ou seja, nem sempre caem onde são produzidos.

\section{SITUAČ̃̃ DE APRENDIZAGEM 4 MODELO ATÔMICO DE JOHN DALTON: IDEIAS SOBRE A CONSTITUIÇÃO E A TRANSFORMAÇÃO DA MATÉRIA}

Nesta Situação de Aprendizagem será discutida a ideia de modelos explicativos como construções humanas influenciadas pelo contexto histórico e social e o modelo atômico proposto por Dalton sobre a constituição da matéria. A transformação química pode ser explicada por meio do modelo de constituição da matéria, assim como suas relações de massa e energia. Apresenta-se também a ideia de elemento químico segundo Dalton.

Tempo previsto: 3 aulas

Conteúdos e temas: modelos explicativos; modelo atômico de Dalton.

Competências e habilidades: interpretar as transformações químicas a partir das ideias de John Dalton sobre a constituição da matéria; compreender modelos e teorias como construções humanas.

Estratégias: simulação de situação: cena de um crime; levantamento das ideias dos alunos; leitura de textos; exposição dialogada.

Recursos: lousa e giz; textos e questões presentes neste Caderno.

Avaliação: respostas às questões e participação na aula. 


\section{Atividade 1 - Modelos explicativos}

A Situação de Aprendizagem pode ser iniciada mostrando-se a importância de construir modelos que explicam os fenômenos observados, visto que o ser humano sempre esteve em busca dessas explicações. Mas também deve ser esclarecido que esses modelos não são verdades absolutas. Como são frutos das atividades humanas, são influenciados pelas ideias vigentes da época em que foram elaborados, ou seja, dependem de seu contexto histórico e social.

Para envolver os alunos numa tarefa que mostre como podem ser criadas as teorias e os modelos explicativos, sugere-se a realização da atividade denominada "Cena de um crime". Para isso, desenhe com giz, no chão da sala, o perfil de uma pessoa e espalhe em volta do desenho vários objetos (o que estiver à mão, como caneta, livro, copo descartável, papel amassado etc.), pedindo aos alunos que, vendo a cena, criem hipóteses sobre o que ocorreu com essa pessoa. Várias suposições poderão ser feitas, como: a pessoa sofreu um ataque, foi ferida ou foi envenenada. A intenção desta atividade é a de que percebam que, ao levantarem uma hipótese, os colegas podem contribuir com ela, aceitando-a e acrescentando outros fatores, como podem refutá-la, apresentando evidências contrárias. Isto é, as ideias devem fluir entre todos os par- ticipantes para que possam chegar a pequenas conclusões, mas nunca se chegará a uma verdade, pois os alunos estão trabalhando apenas com suposições carregadas de seus próprios conceitos, valores e vivências. Deve-se deixar claro que as teorias que eles levantaram estão sujeitas a dúvidas e incertezas e que o mesmo também se dá com os modelos explicativos e teorias elaboradas para explicar os fenômenos observados ao seu redor. Isso pode ser feito com um debate desencadeado pelas seguintes perguntas:

Apresentem as hipóteses que foram levantadas nesta atividade. Todas são plausíveis?

Quem está certo?

A ideia que você tem sobre o que ocorreu na "Cena de um crime" é a realidade? É o que aconteceu de fato ou é uma teoria?

Você pode utilizar uma aula para realizar esta atividade, que servirá para introduzir a atividade seguinte, que trata do modelo atômico de Dalton.

\section{Atividade 2 - Modelo atômico de Dalton}

Inicialmente, peça aos alunos que leiam o texto a seguir. Após a leitura, proponha algumas questões para avaliar o entendimento. 


\section{SITUAÇÃO DE APRENDIZAGEM 4 \\ MODELO ATÔMICO DE JOHN DALTON: IDEIAS SOBRE A CONSTITUIÇÃO E A TRANSFORMAÇÃO DA MATÉRIA}

Sabemos que, nas transformaçôes químicas, as massas se conservam, mas como podemos explicar esse fato?

\section{Atividade 1 - Modelos explicativos}

Para explicar os fenômenos observados, o ser humano elabora teorias e constrói modelos explicativos.

Reflita sobre a atividade que realizou em sala de aula ("Cena de um crime" ou outra atividade) e comente a seguinte frase: "Uma teoria experimentalmente testada nấo é uma verdade".

\section{Atividade 2 - Modelo atômico de Dalton}

\section{Leitura e Análise de Texto}

\section{Modelo atômico de Dalton}

Adaptado por Fabio Luiz de Souza e Luciane Hiromi Akahoshi

No fim do século XVIII, muitos conhecimentos sobre as transformaçốes químicas tinham sido adquiridos, e cientistas buscavam explicaçôes para os fenômenos que observavam, além de sentirem necessidade de representá-los.

John Dalton (1766-1844) foi um dos cientistas que buscou explicar os aspectos quantitativos relacionados às transformaçóes químicas. $\mathrm{O}$ foco de seu estudo era a solubilidade de gases. Em suas pesquisas, ele decidiu aceitar a ideia defendida por Lavoisier de que os gases são formados por corpúsculos. 
Dalton propôs, entấo, que, para diferenciar os corpúsculos dos gases, teria de ser levada em conta a massa, ou seja, que átomos de gases diferentes têm massas diferentes e átomos de gases iguais têm a mesma massa.

Assim, ele passou a estudar as quantidades envolvidas nas transformaçóes químicas e usou a lei de Proust como base para sua hipótese atômica, formulada do seguinte modo:

- Toda matéria é formada por átomos, que săo as menores partículas que a constituem.

- Os átomos são indestrutíveis e indivisíveis, mesmo quando participam de transformaçôes químicas.

- As transformaçóes da matéria săo recombinaçōes de átomos.

- Átomos de elementos iguais apresentam massas iguais e átomos de elementos diferentes apresentam massas diferentes.

Por elemento, Dalton assume a definiçấo proposta por Lavoisier: elemento é toda substância que atingiu sua última fase da análise, ou seja, que não mais se decompóe.

Dalton representava os átomos utilizando símbolos; para o hidrogênio, por exemplo, usava $\odot$. Nessa representação, o símbolo de um elemento indicava não só o elemento, mas também um átomo dele com massa característica. Esse tipo de representaçáo dos elementos químicos se mostrou pouco prático; por isso, outros químicos sugeriram novas formas de representação. O químico sueco Berzelius (1779-1848) propôs usar a primeira letra em maiúscula do nome do elemento em latim; com isso, o hidrogênio passou a ser simbolizado por H. Essa representaçăo é utilizada até hoje. Quando há elementos cujos nomes começam com a mesma letra, acrescenta-se uma segunda (em minúscula), como o nitrogênio (nitrogen), símbolo N, e o sódio (natrium), símbolo Na.

Para Dalton, as fórmulas e as representaçôes das transformaçốes químicas (equaçóes químicas) também indicavam quantidades. Por exemplo, a representaçáo a seguir indicava a formação da água e seria interpretada como:

$\begin{array}{ccccc}\begin{array}{ccc}\odot \\ \text { elemento } \\ \text { hidrogênio }\end{array} & \begin{array}{c}\text { une-se } \\ \text { com }\end{array} & \begin{array}{c}\text { elemento } \\ \text { oxigênio }\end{array} & \text { formando } & \text { água } \\ \text { ou } & & & & \\ 1 \text { átomo de } & \begin{array}{c}\text { une-se } \\ \text { hidrogênio }\end{array} & \begin{array}{c}1 \text { átomo de } \\ \text { oxigênio }\end{array} & \text { formando } & \begin{array}{c}1 \text { átomo } \\ \text { de água }\end{array}\end{array}$

Um problema que se apresentava na época era a determinação das massas dos átomos. Como é impossível medir a massa de um átomo, Dalton analisou as relaçóes entre as massas dos reagentes envolvidos na formaçăo de substâncias hidrogenadas, ou seja, transformaçôes químicas entre diferentes substâncias e o gás hidrogênio. Ele admitiu que o elemento hidrogênio tinha 
massa atômica 1; com isso, pôde estimar as massas de outras substâncias. Por exemplo, na decomposiçấo da água, Dalton obteve 98 partes de oxigênio para 14 de hidrogênio, dando uma proporçấo aproximada de $7: 1$. Dessa maneira, admitiu que a massa dos átomos de oxigênio era aproximadamente sete vezes maior do que a massa dos átomos de hidrogênio, e fez o mesmo para outros compostos hidrogenados.

Contudo, experimentos e estudos do químico francês Gay-Lussac (1778-1850), do físico italiano Avogadro (1776-1856) e de Berzelius mostraram que a partícula de água era constituída por dois átomos de hidrogênio e um de oxigênio; portanto, a massa atômica deste último náo seria 7, como propôs Dalton. Assim, as determinaçôes das massas atômicas foram revistas e, atualmente, esses valores são determinados utilizando-se o carbono como padrăo.

\begin{tabular}{|c|c|c|c|}
\hline \multicolumn{4}{|c|}{ Algumas massas atômicas de Dalton } \\
\hline Massa atômica & $\begin{array}{c}\text { Nome atual } \\
\text { em português }\end{array}$ & Massa atômica & $\begin{array}{c}\text { Nome atual } \\
\text { em português }\end{array}$ \\
\hline 1 & Hidrogênio & 56 & Zinco \\
\hline 5 & Nitrogênio & 56 & Cobre \\
\hline 5 & Carbono & 90 & Chumbo \\
\hline 7 & Oxigênio & 157 & Mercúrio \\
\hline 9 & Fósforo & 190 & Ouro \\
\hline 13 & Enxofre & 190 & Platina \\
\hline 50 & Ferro & 190 & Prata \\
\hline
\end{tabular}

GEPEQ - Grupo de Pesquisa em Educaçáo Química (Org.). Interaçóes e transformaçóes. Química para o Ensino Médio. Livro do Aluno. Elaborando conceitos sobre transformaçóes químicas. Sáo Paulo: Edusp, 2005, v. I, p. 112 (Tabela 7.1)

\section{Questôes para análise do texto}

1. Para Dalton, o que era um átomo?

2. Segundo as ideias de Dalton, que característica diferenciava os átomos dos diversos elementos químicos? 
3. Para Dalton, o que era um elemento químico?

4. Como Dalton representava os átomos? Como eles são representados atualmente?

1. Como as ideias de Dalton a respeito das transformaçōes químicas explicam:

a) a conservação da massa?

b) a proporçẫo entre as substâncias participantes da reação?

1. A tabela a seguir contém dados relativos à queima de um pedaço de palha de aço.

\begin{tabular}{|c|c|c|c|c|c|}
\hline \multirow{2}{*}{$\begin{array}{c}\text { Experi- } \\
\text { mentos }\end{array}$} & \multicolumn{2}{|c|}{ Massa dos reagentes $(\mathbf{g})$} & Massa dos produtos (g) & \multicolumn{2}{|c|}{ Massa que não reagiu (g) } \\
\cline { 2 - 6 } & $\begin{array}{c}\text { Palhinha } \\
\text { (ferro) }\end{array}$ & Oxigênio & Óxido de ferro & $\begin{array}{c}\text { Palhinha } \\
\text { (ferro) }\end{array}$ & Oxigênio \\
\hline I & 22,4 & 11,7 & 32,0 & -- & 2,1 \\
\hline II & 22,4 & 8,6 & 28,5 & 2,6 & -- \\
\hline III & 22,4 & 9,6 & 32,1 & -- & -- \\
\hline
\end{tabular}

GEPEQ - Grupo de Pesquisa em Educaçáo Química. Interaçôes e transformaçóes. Livro de Exercícios. Módulos I e II. Sáo Paulo: Edusp, 2003, v. 1, p. 26. 
Continuando na atividade (Atividade B) sobre a qual estávamos discutindo.

10. Você já realizou em sala de aula atividades semelhantes às sugeridas nas partes 4 e 5? Por quê?

11. Qual sua opinião sobre os alunos elaborarem modelos?

12. O que você acha das propostas de atividades das partes 6 e 7 ?

13. Qual sua opinião sobre a parte final (parte 9) sugerida? Explique.

Nessa Situação de Aprendizagem (Situação de Aprendizagem 01: Explicando o comportamento de materiais: modelos sobre a estrutura da matéria: 1.2 Evolução das ideias: do átomo de Dalton ao átomo de Rutherford-Bohr), o material orienta a retomada breve de algumas ideias de Dalton, já consideradas no primeiro ano, bem como a leitura e a discussão sobre as ideias de Thomson e Rutherford a respeito da constituição do átomo.

14. Qual a sua opinião sobre a discussão desses modelos históricos? O que é mais importante que o aluno saiba? Por quê?

15. De que forma você trabalha/trabalharia essa questão em sala de aula? Por quê? 
c) É possível fazer uma previsâo para a condutibilidade elétrica do carbonato de sódio, do carbonato de cálcio, do hidróxido de potássio e do ácido butanoico? Explique.

\section{2 - Evoluçấo das ideias: do átomo de Dalton ao átomo de Rutherford-Bohr}

\section{Leitura e Análise de Texto}

\section{Ideias de Thomson sobre o átomo - Parte I}

Maria Eunice R. Marcondes e Yvone M. Esperidiáo

Embora o modelo atômico de Dalton explicasse as relaçōes de massa em uma transformação química, suas ideias não foram aceitas por toda a comunidade de cientistas. Propriedades como a natureza elétrica da matéria necessitavam ainda de explicaçóes que o modelo atômico de Dalton não fornecia. Em fins do século XIX e início do século XX, cientistas realizaram inúmeras experiências com a finalidade de investigar a constituiçáo da matéria. Essas experiências evidenciaram a existência de partículas subatômicas dotadas de carga elétrica. Em 1897, Joseph John Thomson (1856-1940), um cientista inglês, havia comprovado experimentalmente que o elétron era um dos constituintes fundamentais de toda e qualquer espécie de matéria.

Em 1898, ele propôs uma nova representaçāo para o átomo. Segundo suas ideias, o átomo poderia ser representado como uma esfera maciça de eletricidade positiva, na qual a massa e as partículas positivas estariam uniformemente distribuídas por todo o seu volume, e os elétrons, corpúsculos de carga negativa, presentes em igual número ao de cargas positivas, estariam incrustados nessa esfera. Pode-se fazer uma analogia com ameixas em um pudim.

Elaborado especialmente para o Säo Paulo faz escola.

\section{Questóes para análise do texto}

1. Qual das representaçôes a seguir poderia corresponder a uma lâmina de ouro segundo as ideias de Dalton? Justifique.

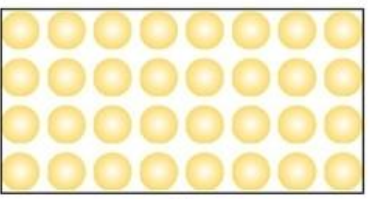

I

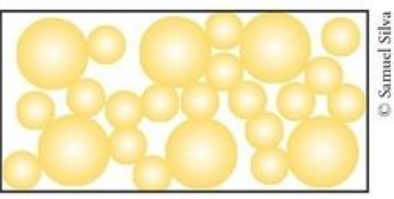

II 
2. Represente a lâmina de ouro supondo que seja constituída por átomos, segundo o modelo de Thomson.

3. Segundo esse modelo, se um átomo contém quatro cargas positivas, quantas cargas negativas ele deve conter? Justifique.

\section{Leitura e Análise de Texto}

\section{Ideias de Rutherford: modelo do átomo nuclear - Parte II}

Maria Eunice R. Marcondes e Yvone M. Esperidiáo

O conhecimento de que a matéria apresenta natureza elétrica propiciou uma nova maneira de pensar sobre os átomos. Outro conhecimento, fundamental para que se elaborassem outros modelos, foi a descoberta da radioatividade.

O cientista francês Henri Becquerel (1852-1908) havia observado (1896) que todos os sais de urânio até entấo conhecidos geravam uma impressão em uma chapa fotográfica, mesmo que ela estivesse no escuro. $\mathrm{O}$ fato foi interpretado considerando-se que o elemento químico urânio pode emitir "raios invisíveis", capazes de penetrar certos materiais. Em 1896, o casal de cientistas Pierre (1859-1906) e Marie Sklodowska Curie (1867-1934) descobriu e isolou outros elementos radioativos, como o polônio e o rádio. Em 1899, Marie Curie sugeriu que os átomos que produzem radiaçôes são instáveis e desintegram-se, transformando-se em outros elementos, com emissão de energia.

Pouco antes, em 1898, Ernest Rutherford (1871-1937), estudando também a radioatividade, descobriu que as radiaçōes eram de dois tipos, denominando-as alfa $(\alpha)$ e beta ( $\beta$ ), e, em 1907, trabalhando com o físico Hans Geiger, descobriu também que, independentemente do elemento radioativo de que proviessem, os raios $\alpha$ eram sempre de mesma natureza. Estudos das propriedades dessas radiaçốes levaram à ideia de que elas fossem constituídas por partículas pesadas e de carga positiva. A radiaçáo $\beta$ foi considerada constituída por partículas "leves" e de carga negativa (feixe de elétrons de alta velocidade). 
Entre 1909 e 1911, Ernest Rutherford e seus colaboradores, Geiger e Marsden, estudavam o comportamento das partículas $\alpha$, emitidas por uma fonte radioativa, como o rádio ou o polônio, quando lançadas como projéteis, em alta velocidade $(10000 \mathrm{~km} / \mathrm{s})$, sobre lâminas muito finas de ouro ou de platina.

As partículas eram detectadas pelas cintilaçóes que produziam em um anteparo recoberto de sulfeto de zinco. O material radioativo era colocado em uma cavidade profunda de um bloco de chumbo, provido de um orifício por onde saía um fino feixe de radiaçôes, em uma única direçáo. O restante delas era absorvido pelo chumbo. A lâmina metálica era intercalada no trajeto dos raios, entre a fonte de partículas $\alpha$ e o anteparo (veja a figura a seguir).

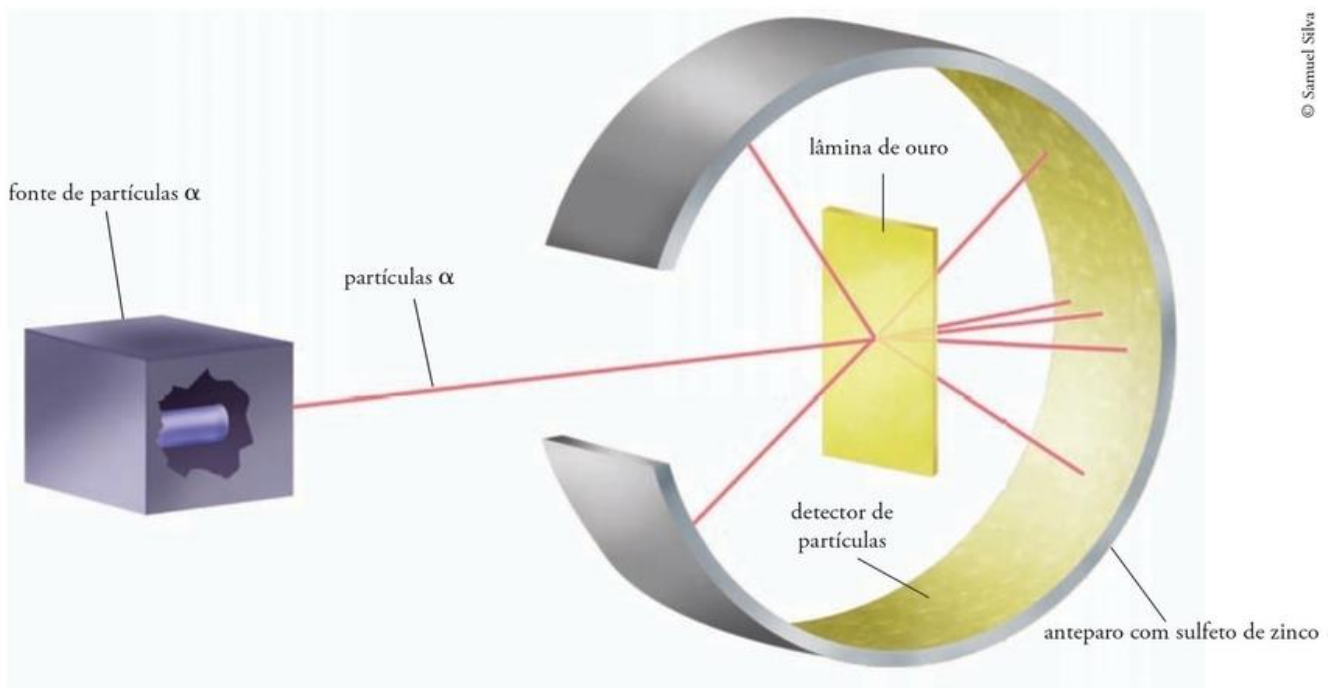

Experimento de Rutherford.

Os resultados surpreenderam os cientistas, pois algumas das partículas $\alpha$ não apresentavam o comportamento esperado - atravessar o anteparo sem se dispersar -, sofrendo desvio, e outras, em número muito menor, eram refletidas. Pode-se imaginar, para fazer uma analogia, um dardo pesado que, quando lançado contra uma folha de papel, em vez de atravessá-la, retorna.

Em 1911, Rutherford propôs um modelo para o átomo, que considerou coerente com suas observaçôes experimentais. Nesse modelo, a massa do átomo estaria concentrada em um núcleo muito menor que o próprio átomo, e esse núcleo apresentaria carga positiva. Ao redor desse núcleo estariam os elétrons, em órbitas circulares, em número suficiente para assegurar um átomo neutro. Usando esse modelo, era possível explicar o fato da maioria das partículas $\alpha$ atravessar a lâmina de metal sem ser desviada, pois existiriam espaços vazios entre o núcleo e as órbitas e entre as próprias órbitas. Mesmo que essas partículas colidissem com os elétrons, estes, por serem leves, não ofereceriam resistência à sua passagem. Os grandes desvios observados podem ser entendidos como resultantes da repulsão eletrostática entre as partículas $\alpha$, positivamente carregadas, e os núcleos também positivos. $\mathrm{O}$ retorno das partículas $\alpha$ é explicado como resultado da colisão frontal, seguida de repulsão, dessas partículas com os próprios núcleos diminutos, mas de grande massa. 
A carga positiva do núcleo dos átomos é devido aos prótons, cuja existência foi evidenciada experimentalmente por Rutherford em 1911. Ele obteve, por meio de cálculos, a carga nuclear de alguns elementos e constatou que os valores encontrados eram aproximadamente a metade do valor da massa atômica relativa do elemento correspondente. Com base nesses dados, previu a existência no núcleo de outra partícula, cuja massa deveria ser igual à do próton, mas desprovida de carga elétrica: o nêutron.

Elaborado especialmente para o São Paulo faz escola.

\section{Questôes para análise do texto}

1. Faça um desenho que represente o modelo para o átomo proposto por Rutherford.

2. Os modelos atômicos propostos por Dalton e por Thomson podem explicar os dados experimentais obtidos por Rutherford no experimento descrito? Explique.

3. Descreva o modelo atômico proposto por Rutherford e apresente as evidências experimentais que justificam tal modelo.

4. O modelo atômico de Rutherford pode ser utilizado para explicar a conservaçáo da massa numa transformação química? Justifique. 


\section{Leitura e Análise de Texto}

\section{Ampliando os conhecimentos sobre o átomo: novas ideias sobre o núcleo e a eletrosfera - Parte III}

Maria Eunice R. Marcondes e Yvone M. Esperidião

Embora o modelo de Rutherford tenha trazido novas explicaçôes sobre a estrutura da matéria, apresentava alguns problemas perante os conhecimentos da época. Sendo os prótons partículas de carga positiva, seria razoável esperar que eles se repelissem. No entanto, eles se mantinham dentro do núcleo, e as ideias de Rutherford revelaram-se insuficientes para explicar a natureza das forças de interaçáo entre eles, as quais dáo ao núcleo uma relativa estabilidade.

Além disso, o modelo admitia os elétrons movendo-se em órbitas circulares ao redor do núcleo. Mas uma carga elétrica, ao girar em torno de outra de sinal contrário, perde energia progressivamente. Assim, os elétrons de um átomo deveriam perder energia e acabariam atingindo o núcleo.

Nessa época, o físico dinamarquês Niels Bohr (1885-1962), baseando-se também em conhecimentos sobre a radiação luminosa (espectros atômicos), propôs, em 1913, uma série de postulados que aprimoraram o modelo de Rutherford:

- No átomo, os elétrons giram em órbitas determinadas, chamadas níveis de energia ou camadas eletrônicas.

- Enquanto giram em determinada órbita, os elétrons năo irradiam energia.

- Em cada órbita, os elétrons têm uma quantidade de energia permitida. Quanto mais próximos estiverem do núcleo, menor a energia dos elétrons em relaçâo ao núcleo. Quanto mais afastados, maior a energia em relação ao núcleo.

- Os elétrons podem passar de uma órbita para outra. Para que passem de uma órbita mais próxima do núcleo para uma mais afastada, é necessário absorver energia; quando os elétrons passam de uma órbita mais afastada para outra mais próxima do núcleo, há liberação de energia (veja a figura a seguir).
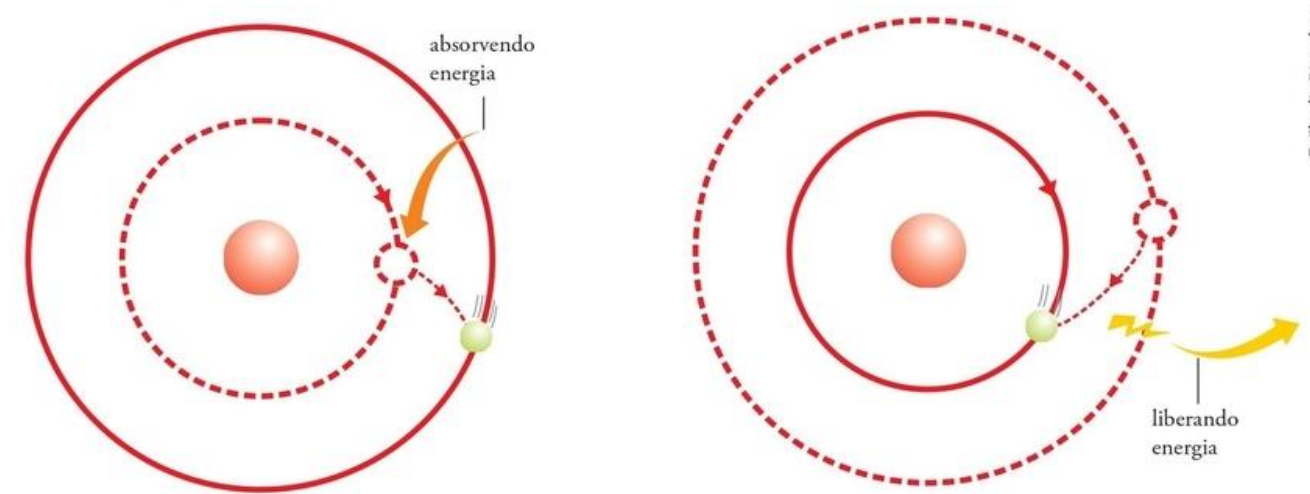

Representaçáo, segundo o modelo de Bohr, da transiçáo do elétron de uma órbita para outra. 
Bohr percebeu que a energia dos elétrons năo é emitida de maneira contínua, como era esperado segundo os conhecimentos da época, mas que eles emitem (ou absorvem) certos valores de energia apenas quando mudam de órbita. A organizaçâo dos elétrons nos vários níveis de energia, segundo Bohr, levava em conta um número fixo de elétrons em um dado nível. Baseado em uma relaçăo matemática estabelecida pelo cientista sueco Rydberg, no final do século XIX, para o número de elétrons dos gases nobres, Bohr notou uma regularidade: os números 2, 8 , 18 e 32 representavam as diferenças entre o total de elétrons de um dado gás nobre e o total de elétrons de seu anterior. Levando em conta a pouca reatividade manifestada pelos gases nobres, Bohr considerou que esses números correspondiam ao número máximo de elétrons permitido em cada nível e apresentou o seguinte quadro:

\section{Distribuiçáo eletrônica segundo o modelo atômico de Bohr}

\begin{tabular}{|c|c|c|c|c|c|c|c|}
\hline Camada eletrônica & $\mathrm{K}$ & $\mathrm{L}$ & $\mathrm{M}$ & $\mathrm{N}$ & $\mathrm{O}$ & $\mathrm{P}$ & $\mathrm{Q}$ \\
\hline Nível de energia & 1 & 2 & 3 & 4 & 5 & 6 & 7 \\
\hline $\begin{array}{c}\text { Número máximo de } \\
\text { elétrons }\end{array}$ & 2 & 8 & 18 & 32 & 32 & 18 & 2 \\
\hline
\end{tabular}

Essas ideias contribuíram para ampliar os conhecimentos sobre a estrutura dos átomos.

Elaborado especialmente para o Sáo Paulo faz escola.

\section{Questōes para análise do texto}

1. Quais são as semelhanças e diferenças entre as ideias de Rutherford e as de Bohr?

2. O teste de chama é um procedimento muito usado na identificação de substâncias químicas. Sabe-se que uma substância, quando aquecida a determinada temperatura, emite luz de frequências bem definidas, que sáo características dos átomos que a constituem. Assim, por exemplo, o átomo de sódio emite luz amarela; o de cálcio, alaranjada; o de estrôncio, vermelho carmim. Utilizando as ideias de Rutherford e de Bohr, procure explicar essa característica apresentada por certos átomos. 


\section{O número atômico e a descoberta do nêutron}

As ideias de Bohr permitiram que se entendesse a organizaçáo dos elétrons na eletrosfera. Quanto ao núcleo atômico, embora tivesse carga positiva e concentrasse a massa do átomo, năo se sabia ainda a magnitude dessas cargas, e Rutherford havia previsto a existência de outras partículas, além dos prótons, responsáveis também pela massa do átomo.

Por volta de 1914, um jovem cientista, Henry Moseley, quando estudava os raios X, verificou experimentalmente ser possível associar a cada elemento um valor que representava a carga nuclear desse elemento e que correspondia ao número de ordem do elemento na tabela periódica de Mendeleev. Esse número, chamado número atômico, representa o número de prótons do átomo do elemento. Levando isso em conta, pode-se definir elemento químico como um conjunto de átomos de mesmo número atômico $(\mathrm{Z})$.

A questáo da massa nuclear só foi resolvida em 1932, vinte anos depois das ideias apresentadas por Rutherford sobre a estrutura do átomo. O cientista James Chadwick, estudando o bombardeamento de átomos com partículas $\alpha$, descobriu os nêutrons, partículas constituintes do núcleo atômico, desprovidas de carga elétrica e com massa igual à do próton. A questáo da massa nuclear apresentada por Rutherford havia, assim, sido solucionada.

O total de prótons e de nêutrons do núcleo é chamado de número de massa do átomo (A).

A notação ${ }_{Z}^{A} X$ tem sido adotada para representar os átomos; X é o símbolo do elemento químico; $\mathrm{A}$, seu número de massa; $\mathrm{e} Z$, seu número atômico.

No entanto, átomos de um mesmo elemento, embora tenham números atômicos idênticos e comportem-se quimicamente de modo semelhante, podem apresentar diferentes números de nêutrons. Átomos desse tipo, com o mesmo número atômico e que diferem apenas pelo número de nêutrons presentes no núcleo atômico, sáo chamados isótopos. Na natureza, a maioria dos elementos químicos é constituída por uma mistura de isótopos (mistura isotópica). Alguns exemplos săo dados a seguir:

\begin{tabular}{|c|c|c|c|c|}
\hline \multicolumn{5}{|c|}{ Alguns elementos químicos e seus isótopos } \\
\hline $\begin{array}{c}\text { Notaçáo do } \\
\text { isótopo }\end{array}$ & $\begin{array}{c}\text { Número de } \\
\text { massa }\end{array}$ & $\begin{array}{c}\text { Número de } \\
\text { prótons }\end{array}$ & $\begin{array}{c}\text { Número de } \\
\text { nêutrons }\end{array}$ & \% na natureza \\
\hline${ }_{1}^{1} \mathrm{H}$ & 1 & 1 & 0 & 99,99 \\
\hline${ }_{1}^{2} \mathrm{H}$ (deutério) & 2 & 1 & 1 & 0,01 \\
\hline${ }_{1}^{3} \mathrm{H}$ (trítio) & 3 & 1 & 2 & - \\
\hline${ }_{8}^{16} \mathrm{O}$ & 16 & 8 & 8 & 99,76 \\
\hline${ }_{8}^{17} \mathrm{O}$ & 17 & 8 & 9 & 0,04 \\
\hline${ }_{8}^{18} \mathrm{O}$ & 18 & 8 & 10 & 24,1 \\
\hline${ }_{82}^{206} \mathrm{~Pb}$ & 206 & 82 & 126 & 52,4 \\
\hline${ }_{82}^{208} \mathrm{~Pb}$ & 208 & & \multicolumn{2}{c|}{ Elaborada pelas autoras especialmente para o Säo Paulo faz escola. } \\
\hline
\end{tabular}




\section{Questóes para análise do texto}

1. Número atômico é o mesmo que número de massa?

2. Complete o quadro a seguir, preenchendo os espaços em branco:

\begin{tabular}{|c|c|c|c|c|c|}
\hline $\begin{array}{c}\text { Nome do } \\
\text { elemento }\end{array}$ & Prótons & Nêutrons & Elétrons & $\begin{array}{c}\text { Número } \\
\text { atômico }\end{array}$ & $\begin{array}{c}\text { Número } \\
\text { de massa }\end{array}$ \\
\hline Neônio & & 10 & 10 & 10 & \\
\hline & 11 & & 11 & & 23 \\
\hline & & & 17 & 17 & 35 \\
\hline Estrôncio & & & 38 & & 87 \\
\hline
\end{tabular}

3. O que são isótopos? Cite exemplos e apresente argumentos que justifiquem por que isótopos têm o mesmo comportamento químico.

\section{Desafio!}

Busque informaçóes sobre a utilizaçáo de alguns radioisótopos naturais, como o carbono-14 $\left(\mathrm{C}-14\right.$ ou $\left.{ }_{6}^{14} \mathrm{C}\right)$ na determinaçáo da idade de fósseis, ou o U-238 (ou $\left.{ }_{92}^{238} \mathrm{U}\right)$ na determinaçáo da idade da Terra ou das rochas, ou o I-131 em medicina. 
Construa um quadro com a síntese das ideias contidas nos textos sobre Thomson, Rutherford e Bohr para compará-las. Um esboço é mostrado a seguir.

\section{Ideias sobre a constituiçáo do átomo}

Ideias de Thomson (1898)

Ideias de Rutherford (1911)

Ideias de Bohr (1913) 
Tenho comigo algumas sugestões para abordar os modelos atômicos. Gostaria de the mostrar a ideia geral de uma dessas atividades.

16. O que você pensa a respeito dessa proposta (Atividade $\boldsymbol{C}$ )? Ela é importante para a formação do estudante? 


\section{Atividade C}

Após retomar as limitações do modelo de Dalton, o professor propõe a leitura de um texto que apresenta, brevemente, o contexto histórico no qual as ideias de Thomson e Rutherford sobre o átomo foram desenvolvidas.

Depois, medeia uma discussão a respeito da complexidade envolvida no processo de elaboração desses modelos, na qual os seguintes assuntos são abordados:

- Os diversos modelos atômicos em discussão na época.

- Os debates e divergências a respeito da localização das cargas elétricas e da estabilidade do átomo.

- As questões que levaram Thomson e Rutherford a desenvolver suas ideias.

- A importância das contribuições de Geiger e Marsden para a elaboração do modelo de Rutherford.

- A influência da formação acadêmica e de outras teorias na elaboração dos modelos de Thomson e Rutherford.

- As diferenças entre os modelos de Thomson e Rutherford e a contribuição de cada um deles para o desenvolvimento da química. 


\section{G - Experimentação}

1. Na sua opinião, qual a importância da experimentação no ensino de química?

2. Descreva alguma atividade envolvendo experimentação que você fez com os alunos e considera bem-sucedida. Por que você trabalhou desse modo? Por que você considera que ela foi bem-sucedida?

3. Como geralmente são suas aulas antes, durante e depois dos experimentos? E os estudantes, o que comumente fazem antes, depois e durante os experimentos?

4. Na sua opinião, quais são as principais características de uma boa atividade experimental? O que seria uma atividade experimental ideal para você?

5. Quais seus objetivos ao inserir atividades experimentais em sua prática docente? Ou seja, o que você pretende que os estudantes desenvolvam ao trabalhar com atividades experimentais? O que é mais importante para você, nesse sentido? Por quê?

Gostaria de the apresentar uma discussão proposta para a primeira série do ensino médio (Atividade $\boldsymbol{D}$ ).

6. Na parte 3, propõe-se uma discussão sobre os resultados dos experimentos. O que você acha dessa proposta? (Você trabalhou ou trabalharia sob essa perspectiva na sala de aula? Por quê?)

7. Na parte 4, sugere-se uma discussão sobre a experimentação realizada pelos alunos. Qual sua opinião sobre essa proposta? (Quais os objetivos da atividade? Você já fez ou faria uma atividade desse tipo? Por quê?)

8. Nas partes 5 e 6 , a proposta é fazer uma abordagem histórica. Qual a sua opinião sobre abordar com os alunos o flogístico e as ideias de Lavoisier?

9. O que você pensa sobre os assuntos a serem discutidos pelo professor na parte 6 , com base na leitura dos textos?

10. Qual a sua opinião sobre a parte 7? Você acha essa discussão importante para a formação dos estudantes? Por quê? 


\section{Atividade D}

\section{Tema: Transformações químicas - Introdução ao tema}

\section{Parte 1 - Introducão}

- Professor discute com os alunos a importância da energia para a sociedade e as formas de se obtê-la.

- Depois, comenta sobre a importância da combustão para o ser humano no decorrer da história e atualmente.

- Após a discussão, as seguintes perguntas são realizadas para introduzir a próxima atividade: o que é combustão, como explicá-la?

\section{Parte 2 - Experimento}

- Estudantes, em grupos, realizam a combustão de amostras de palha de aço e de algodão, registrando as massas dos materiais antes e depois do aquecimento.

- Os estudantes elaboram uma explicação para o fenômeno observado, justificando as suas ideias.

\section{Parte 3 - Discussão}

- Os estudantes comunicam as suas ideias para os seus colegas.

- O professor expõe os diferentes pontos de vista e as justificativas.

- Depois, o professor, por meio de perguntas, leva os estudantes a testarem suas concepções iniciais.

- As explicações são negociadas em busca de um consenso, seguindo determinados critérios estabelecidos pelo professor.

\section{Parte 4 - Reflexão sobre as atividades realizadas}

- O professor promove uma discussão com os estudantes com base nas seguintes questões:

- O que fez vocês explicarem os resultados do experimento da maneira que fizeram?

- Você e seus colegas explicaram os resultados da mesma forma? Por quê?

- Será que há na ciência apenas uma maneira de interpretar um fenômeno?

- Você modificou as suas explicações após a discussão promovida pelo professor? Por quê?

- Será que os cientistas modificam suas explicações?

\section{Parte 5 - Leitura do texto - A busca de explicacões}

- O professor trabalha com os alunos um pequeno texto histórico que aborda a teoria do flogístico de Stahl e também as ideias de Lavoisier.

- O professor propõe aos alunos que procurem explicar os resultados do experimento por meio da teoria do flogístico e da teoria de Lavoisier.

\section{Parte 6 - Discussão sobre os textos}

- O professor discute com os alunos o significado de teoria e aponta os motivos que levaram a teoria do flogístico a ser aceita por muitos "químicos" e os momentos de confronto e debate com outras correntes do pensamento químico.

- O professor aponta os pressupostos teóricos utilizados por Lavoisier em suas pesquisas e como e porque suas ideias foram aceitas pela comunidade científica. 
- O professor também enfatiza a contribuição de outros químicos ao trabalho de Lavoisier, e como as ideias de Lavoisier foram se modificando lentamente com o decorrer de seus estudos.

\section{Parte 7 - Fechamento da atividade}

- O professor retoma com os alunos os seguintes pontos, os quais foram levantados nas discussões anteriores:

- O papel das teorias e da experimentação no desenvolvimento da ciência.

- A influência das ideias prévias na elaboração das explicações científicas.

- O fato de um mesmo fenômeno ser interpretado de diferentes maneiras.

- Cooperação e colaboração no desenvolvimento científico. 
Também gostaria da sua opinião sobre uma outra atividade (Atividade $\boldsymbol{E}$ ). Nessa atividade, sugere-se a utilização de alguns artigos adaptados para o ensino médio, visando discutir a experimentação na química.

11. Qual a sua opinião sobre ela? Esses assuntos são relevantes para os estudantes? Por quê? 


\section{Atividade E}

Descrição resumida da atividade

Leitura de artigos, adaptados para o Ensino Médio, envolvendo pesquisas recentes em química, como a produção de nanomateriais e suas aplicações. A partir da leitura do artigo e de outras informações fornecidas aos estudantes, o professor discute:

- as funções dos experimentos na química;

- as principais atividades dos químicos atualmente;

- o papel das teorias na experimentação em química;

- o papel dos instrumentos na pesquisa química. 
H - Reducionismo

Gostaria de the apresentar três propostas de atividade envolvendo a substância água.

1. Nos cadernos do Estado há algumas atividades envolvendo propriedades da água e de outras substâncias (Situação de Aprendizagem 01: Forças de Interação entre Partículas nos Estados Sólido, Líquido e Gasoso. Atividade 04: Ligações de hidrogênio e propriedades peculiares da água). Como você costuma abordar essa questão? O que é mais importante que o aluno saiba? Por quê? 


\section{Atividade 4 - Ligaçốes de hidrogênio e as propriedades peculiares da água}

Nesta atividade, considerando as interaçốes intermoleculares, vamos procurar entender algumas das propriedades físicas que a água apresenta. Você vai precisar da tabela periódica que consta no final do Caderno para responder às questóes.

\section{Questóes para a sala de aula}

1. O gráfico a seguir relaciona as temperaturas de ebuliçáa com as massas molares de algumas substâncias formadas por hidrogênio e elementos do grupo do carbono e por hidrogênio e elementos do grupo do oxigênio.

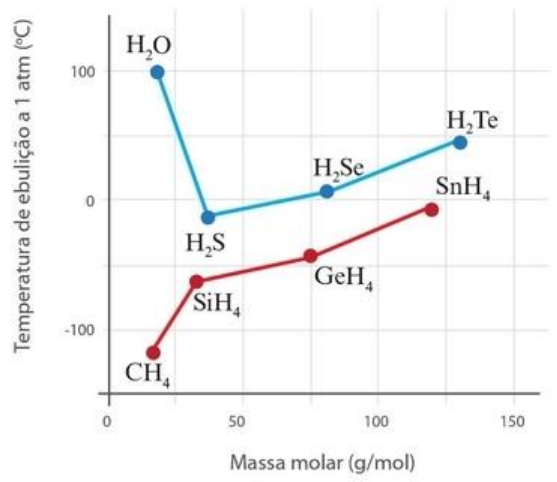

a) Localize na tabela periódica os grupos citados.

b) As ligaçóes entre os átomos que formam essas substâncias são do mesmo tipo? Justifique. 
2. Analisando o gráfico, descreva cada uma das curvas considerando a variaçáo da temperatura de ebulição em função da variação da massa molar das substâncias. Existe alguma regularidade?

3. A água, em relaçáo à sua temperatura de ebuliçáo, tem um comportamento semelhante ao das outras substâncias do mesmo grupo do oxigênio? Justifique.

4. As forças de atração entre as moléculas de $\mathrm{H}_{2} \mathrm{O}$ são de mesma intensidade que as forças de atraçăo entre as moléculas de $\mathrm{H}_{2} \mathrm{~S}$, de $\mathrm{H}_{2} \mathrm{Se}$ e de $\mathrm{H}_{2}$ Te? Justifique.

5. Como você imagina a atraçấo entre as moléculas de água? Considere as interaçóes eletrostáticas entre suas moléculas. Que tipo de interaçōes mantém as moléculas de água unidas? 
6. Faça um esquema que represente suas ideias. Lembre-se de que a água é polar, podendo ser representada pela fórmula a seguir, em que $\delta^{+}$corresponde à regiáo de carga positiva da molécula $\mathrm{H}_{2} \mathrm{O}$ e $\delta$ corresponde à regiáo de carga negativa.

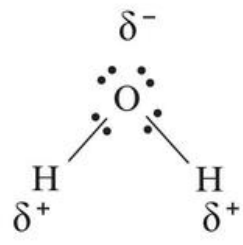

7. Utilizando a ideia de "ligação de hidrogênio", represente a água no estado líquido e no estado sólido. Utilize suas representaçōes para explicar o menor valor de densidade da água no estado sólido, quando comparado com o líquido, e o valor da temperatura de ebuliçấo.

\section{Desafio!}

Considerando seus conhecimentos sobre os modelos de ligaçăo que explicam as propriedades de uma substância iônica e as da $\mathrm{H}_{2} \mathrm{O}$, proponha ideias que expliquem, em nível microscópico, a dissoluçấo da substância iônica em água. Procure representar suas ideias com um desenho. Tome como exemplo a dissolução do $\mathrm{NaCl}$ em água. 
1. Analise o gráfico a seguir, que contém informações sobre as temperaturas de ebulição de compostos de hidrogênio com elementos dos grupos 15 (do nitrogênio) e 17 (dos halogênios) da tabela periódica.

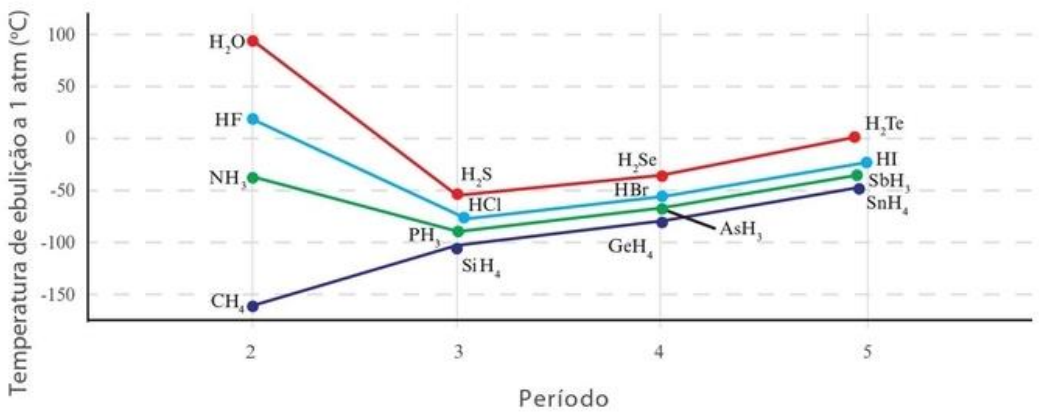

a) Descreva o que você observa em relação às temperaturas de ebuliçấo desses compostos. 
2. Continuando, qual sua opinião sobre as discussões sugeridas na Atividade $F$ ? 


\section{Atividade F}

\section{Parte 1 - Breve descrição das atividades introdutórias que podem ser realizadas}

I) Questões para estimular a discussão

Os estudantes observam uma garrafa de vidro contendo água identificada com uma etiqueta contendo a inscrição " $\mathrm{H}_{2} \mathrm{O}$ " e a palavra "água". Depois, o professor conduz uma discussão com base nas seguintes questões:

- Poderia uma molécula de água ferver a $100^{\circ} \mathrm{C}$ ?

- É $\mathrm{H}_{2} \mathrm{O}$ a mesma coisa que água?

II) Avaliando uma alegação

O professor escreve na lousa a seguinte frase "Água é $\mathrm{H}_{2} \mathrm{O}$ ” e depois realiza uma discussão com os estudantes com base nas seguintes questões:

- Você concorda com essa afirmação? Por quê?

III) Questões para estimular a discussão

O professor escreve na lousa as seguintes frases:

- "Água $=\mathrm{H}_{2} \mathrm{O}$ "

- "Gelo $=\mathrm{H}_{2} \mathrm{O}$ "

- "Então, água = gelo"

Depois, pede a opinião dos estudantes sobre a conclusão. Para estimular o debate, o professor pode utilizar questões como:

- Pode a experiência da água como um líquido incolor e do gelo como um sólido branco ser reduzida para $\mathrm{H}_{2} \mathrm{O}$ ?

\section{Parte 2 - Leitura de texto}

Depois da discussão, o professor utiliza textos históricos abordando a disputa sobre a fórmula da água ser $\mathrm{HO}$ ou $\mathrm{H}_{2} \mathrm{O}$. Após a leitura, pode-se considerar novamente com os alunos os pontos questionados na atividade introdutória. 
Agora gostaria de conversar com você o tema Equilíbrio Químico:

3. Como você costuma tratar desse assunto? O que é mais importante que o estudante aprenda? Quais são seus objetivos ao abordar essa questão? Por quê?

4. O que você pensa do modo como o tema equilíbrio químico está desenvolvido no material do Estado? Além do estudo da amônia, já visto, esse tema também é abordado em outras atividades (Situação de aprendizagem 03: Como saber as quantidades de produtos e de reagentes que coexistem em equilíbrio químico: Atividade 02 e 03; Situação de Aprendizagem 04: Influência das variações de temperatura e pressão em sistemas em equilíbrio). Quais modificações você faria? 


\section{Atividade 2 - Construçáo empírica da constante de equilíbrio químico}

$\mathrm{O}$ ácido acético em água năo se ioniza totalmente e entra em equilíbrio químico. $\mathrm{Na}$ tabela a seguir săo apresentadas as concentraçōes das espécies em equilíbrio em soluçōes aquosas preparadas a partir de diferentes concentraçôes iniciais de ácido acético a $25^{\circ} \mathrm{C}$.

$$
\mathrm{H}_{3} \mathrm{CCOOH}(\mathrm{aq}) \rightleftharpoons \mathrm{H}^{+}(\mathrm{aq})+\mathrm{H}_{3} \mathrm{CCOO}^{-}(\mathrm{aq})
$$

\begin{tabular}{|c|c|c|c|c|}
\hline Solução & $\begin{array}{c}\text { Concentração } \\
\text { inicial de ácido } \\
\text { acético }\left(\text { mol.L } \mathbf{L}^{-1}\right)\end{array}$ & \multicolumn{3}{|c|}{ Concentraçôes no equilíbrio (mol.L-1) } \\
\hline & {$\left[\mathrm{H}_{3} \mathrm{CCOOH}(\mathrm{aq})\right]$} & {$\left[\mathrm{H}_{3} \mathrm{CCOOH}(\mathrm{aq})\right]$} & {$\left[\mathrm{H}^{+}(\mathrm{aq})\right]$} & {$\left[\mathrm{H}_{3} \mathrm{CCOO}^{-}(\mathrm{aq})\right]$} \\
\hline 1 & 0,100 & 0,0987 & 0,00133 & 0,00133 \\
\hline 2 & 0,0100 & 0,00958 & 0,000415 & 0,000415 \\
\hline 3 & 0,200 & 0,198 & 0,00188 & 0,00188 \\
\hline
\end{tabular}

1. Calcule o valor da relaçáo $\left[\mathrm{H}^{+}(\mathrm{aq})\right] \cdot\left[\mathrm{H}_{3} \mathrm{CCOO}^{-}(\mathrm{aq})\right] /\left[\mathrm{H}_{3} \mathrm{CCOOH}(\mathrm{aq})\right]$ para cada soluçáo e complete a tabela abaixo. Note que essa expressão permite avaliar a proporção entre as espécies em equilíbrio.

\begin{tabular}{|c|c|}
\hline Soluçáo & {$\left[\mathrm{H}^{+}(\mathbf{a q})\right] \cdot\left[\mathrm{H}_{3} \mathrm{CCOO}^{-}(\mathbf{a q})\right] /\left[\mathrm{H}_{3} \mathrm{CCOOH}(\mathbf{a q})\right]$} \\
\hline 1 & \\
\hline 2 & \\
\hline 3 & \\
\hline
\end{tabular}

2. Essa relaçăo é constante? Escreva a expressão da constante de equilíbrio para essa reaçáo. 
1. Escreva a expressão da constante de equilíbrio para as reaçóes:

$$
\begin{aligned}
& \mathrm{H}_{2}(\mathrm{~g})+\mathrm{CO}_{2}(\mathrm{~g}) \rightleftharpoons \mathrm{H}_{2} \mathrm{O}(\mathrm{g})+\mathrm{CO}(\mathrm{g}) \\
& 2 \mathrm{NO}(\mathrm{g})+\mathrm{O}_{2}(\mathrm{~g}) \rightleftharpoons 2 \mathrm{NO}_{2}(\mathrm{~g}) \\
& 2 \mathrm{HI}(\mathrm{g}) \rightleftharpoons \mathrm{H}_{2}(\mathrm{~g})+\mathrm{I}_{2}(\mathrm{~g})
\end{aligned}
$$

2. Escreva um parágrafo explicando por que a concentraçâo de água não é escrita na constante de equilíbrio de ionização da água.

\section{Atividade 3 - Relaçáo entre o valor da constante de equilíbrio e a extensáo de uma transformaçáo}

Será que é possível relacionar o valor da constante de equilíbrio com a extensăo de uma transformaçáo, ou seja, com a quantidade de produtos formados em relaçáo à quantidade de reagentes? Nesta atividade, vamos buscar a resposta para essa questáo por meio da análise de expressóes de constantes de equilíbrio.

1. Analise os equilíbrios químicos envolvendo a formação de soluçôes ácidas apresentados a seguir e responda às questôes propostas:
I. $\mathrm{H}_{2} \mathrm{SO}_{3}(\mathrm{aq}) \rightleftharpoons \mathrm{H}^{+}(\mathrm{aq})+\mathrm{HSO}_{3}^{-}(\mathrm{aq})$
$\mathrm{Ka}=1,7 \cdot 10^{-2}$
II. $\mathrm{HF}(\mathrm{aq}) \rightleftharpoons \mathrm{H}^{+}(\mathrm{aq})+\mathrm{F}^{-}(\mathrm{aq})$
$\mathrm{Ka}=6,7 \cdot 10^{-4}$
III. $\mathrm{C}_{6} \mathrm{H}_{5} \mathrm{COOH}(\mathrm{aq}) \rightleftharpoons \mathrm{H}^{+}(\mathrm{aq})+\mathrm{C}_{6} \mathrm{H}_{5} \mathrm{COO}^{-}(\mathrm{aq})$
$\mathrm{Ka}=6,6 \cdot 10^{-5}$ 
$\mathrm{IV} \cdot \mathrm{HClO}(\mathrm{aq}) \rightleftharpoons \mathrm{H}^{+}(\mathrm{aq})+\mathrm{ClO}^{-}(\mathrm{aq}) \quad \mathrm{Ka}=3,7 \cdot 10^{-8}$

a) Escreva a expressão que representa a constante de equilíbrio químico em função das concentraçōes em mol. $\mathrm{L}^{-1}$ para cada um dos sistemas apresentados.

b) Considerando as expressóes escritas no item a e os valores para cada uma das constantes apresentadas nas equaçōes acima, qual das soluçōes apresentará maior extensāo no processo de formaçáo de produtos?

2. Analise agora os equilíbrios químicos envolvendo a formaçấo de soluçôes básicas apresentados a seguir e responda às questốes propostas:
I. $\mathrm{LiOH}(\mathrm{s}) \stackrel{\text { água }}{\rightleftharpoons} \mathrm{Li}^{+}(\mathrm{aq})+\mathrm{OH}^{-}(\mathrm{aq})$
$\mathrm{Kb}=6,6 \cdot 10^{-1}$
II. $\mathrm{NaOH}(\mathrm{s}) \stackrel{\text { água }}{\rightleftharpoons} \mathrm{Na}^{+}(\mathrm{aq})+\mathrm{OH}^{-}(\mathrm{aq})$
$\mathrm{Kb}=4$
III. $\mathrm{Ca}(\mathrm{OH})_{2}(\mathrm{~s}) \stackrel{\text { água }}{\rightleftharpoons} \mathrm{CaOH}^{+}(\mathrm{aq})+\mathrm{OH}^{-}(\mathrm{aq})$
$\mathrm{Kb}=4 \cdot 10^{-2}$

Qual dessas transformaçốes ocorre em maior extensão? Escreva as expressóes para ajudar a fundamentar a sua resposta.

Obs.: nấo se esqueça de que há materiais no estado sólido. 
Analise a tabela e responda às questốes a seguir.

\begin{tabular}{|l|c|c|}
\hline \multicolumn{1}{|c|}{ Ácido } & Reaçáo de ionizaçáo & Constante de equilíbrio \\
\hline Sulfuroso & $\mathrm{H}_{2} \mathrm{SO}_{3}(\mathrm{aq}) \rightleftharpoons \mathrm{H}^{+}(\mathrm{aq})+\mathrm{HSO}_{3}^{-}(\mathrm{aq})$ & $1,7.10^{-2}$ \\
\hline Fórmico & $\mathrm{HCOOH}(\mathrm{aq}) \rightleftharpoons \mathrm{H}^{+}(\mathrm{aq})+\mathrm{HCOO}^{-}(\mathrm{aq})$ & $1,8.10^{-4}$ \\
\hline Hipocloroso & $\mathrm{HClO}(\mathrm{aq}) \rightleftharpoons \mathrm{H}^{+}(\mathrm{aq})+\mathrm{ClO}^{-}(\mathrm{aq})$ & $3,0.10^{-8}$ \\
\hline Fluorídrico & $\mathrm{HF}(\mathrm{aq}) \rightleftharpoons \mathrm{H}^{+}(\mathrm{aq})+\mathrm{F}^{-}(\mathrm{aq})$ & $3,5.10^{-4}$ \\
\hline
\end{tabular}

a) Qual dos ácidos apresentados sofre maior ionizaçấo? Escreva as constantes de equilíbrio para cada ácido e baseie sua resposta nessas expressóes.

b) Considerando as soluçốes $0,1 \mathrm{~mol} / \mathrm{L}$ desses ácidos, qual apresenta o menor $\mathrm{pH}$ ? Calcule esse valor.

c) Sabendo que, quanto mais forte for um ácido, maior será a extensã́o de sua ionizaçáo, qual dos ácidos é o mais forte? Qual é o mais fraco? 


\section{SITUAÇĀO DE APRENDIZAGEM 4}

INFLUÊNCIA DAS VARIAÇÓESS DE TEMPERATURA E PRESSÃO EM SISTEMAS EM EQUILÍBRIO QUÍMICO

Como se pode aumentar a quantidade de produtos formados, ou seja, como se pode aumentar a extensão de uma transformação química que já se encontra em um estado de equilíbrio químico?

Como foi visto na Situaçáo de Aprendizagem anterior, muitas soluçóes aquosas ácidas constituem-se em sistemas que se encontram em equilíbrio químico. Dado que a acidez de soluçôes está diretamente ligada à manutençáo da vida, como, por exemplo, à sobrevivência de espécies animais em ambientes aquáticos e à manutenção do $\mathrm{pH}$ sanguíneo, o controle dessa acidez - sua manutençấo ou modificação - é muito importante.

Nesta atividade serão discutidas perturbaçóes em equilíbrios químicos causadas por mudanças de temperatura ou de pressáo.

\section{Influência da temperatura}

\section{Questóes para a sala de aula}

1. Escreva a equação que representa o equilíbrio de autoionização da água, assim como a expressáo de sua constante de equilíbrio (Kw).

2. Usando a expressáo que permite o cálculo do $\mathrm{pH}$, calcule o $\mathrm{pH}$ das águas nas temperaturas especificadas na tabela a seguir, completando-a com os valores calculados.

\begin{tabular}{|c|c|c|}
\hline Temperatura $\left({ }^{\circ} \mathbf{C}\right)$ & $\mathbf{K w}\left(\mathbf{m o l}^{\mathbf{2}} \cdot \mathbf{L}^{-2}\right)$ & $\mathbf{p H}$ \\
\hline 0 & $0,11.10^{-14}$ & \\
\hline 10 & $0,30.10^{-14}$ & \\
\hline 20 & $0,68 \cdot 10^{-14}$ & \\
\hline 25 & $1,00.10^{-14}$ & \\
\hline 50 & $5,47.10^{-14}$ & \\
\hline 100 & $51,3.10^{-14}$ & \\
\hline
\end{tabular}


3. $\mathrm{O} \mathrm{pH}$ da água mudou? $\mathrm{O}$ que foi alterado para que isso acontecesse? A água continua neutra? Explique.

4. Verifique os valores de energias (entalpias) das transformaçóes envolvidas no equilíbrio de autoionizaçáo da água.

$$
\begin{array}{ll}
\mathrm{H}_{2} \mathrm{O}(\mathrm{l}) \rightarrow \mathrm{H}^{+}(\mathrm{aq})+\mathrm{OH}^{-}(\mathrm{aq}) & \Delta \mathrm{H}=+58 \mathrm{~kJ} \text { (transformação endotérmica) } \\
\mathrm{H}^{+}(\mathrm{aq})+\mathrm{OH}^{-}(\mathrm{aq}) \rightarrow \mathrm{H}_{2} \mathrm{O}(\mathrm{l}) & \Delta \mathrm{H}=-58 \mathrm{~kJ} \text { (transformação exotérmica) }
\end{array}
$$

Sabendo que essas transformaçóes acontecem simultaneamente e com a mesma rapidez (estáo em equilíbrio químico), e considerando os valores de $\mathrm{Kw}$ apresentados na tabela da página 23, estabeleça alguma relação entre o aumento da temperatura com o favorecimento da transformação de ionização da água ou de formação da água.

5. A transformaçăo descrita por $\mathrm{CO}(\mathrm{g})+\mathrm{H}_{2} \mathrm{O}(\mathrm{g}) \rightleftharpoons \mathrm{CO}_{2}(\mathrm{~g})+\mathrm{H}_{2}(\mathrm{~g})$ admite os seguintes valores para a constante de equilíbrio Kc:

\begin{tabular}{|c|c|c|c|}
\hline $\mathbf{T ~}\left({ }^{\circ} \mathbf{C}\right)$ & 225 & 625 & 995 \\
\hline $\mathbf{K c}$ & 0,007 & 0,455 & 1,76 \\
\hline
\end{tabular}

Sabendo-se que a transformação $\mathrm{CO}(\mathrm{g})+\mathrm{H}_{2} \mathrm{O}(\mathrm{g}) \rightarrow \mathrm{CO}_{2}(\mathrm{~g})+\mathrm{H}_{2}$ (g) é endotérmica, o aumento da temperatura do sistema favorece ou desfavorece a formaçáo de $\mathrm{CO}_{2}$ ? Para responder, escreva a expressão da constante de equilíbrio químico para essa transformaçấo e analise os dados apresentados na tabela.

6. Concluindo: o aumento da temperatura a transformação endotérmica de um equilíbrio químico e da temperatura favorece a transformaçáo exotérmica de um equilíbrio químico. 


\section{Influência da pressáo}

Para estudar a influência da pressão no equilíbrio químico, vamos considerar a dissoluçấo do gás oxigênio em água.

A quantidade de gás oxigênio dissolvido na água é essencial para todas as espécies que vivem no ambiente aquático. A tabela a seguir mostra diferentes concentraçốes desse gás dissolvido em água, a $25^{\circ} \mathrm{C}$, a diferentes pressōes. Essa dissoluçáo pode ser representada por:

$$
\mathrm{O}_{2}(\mathrm{~g}) \stackrel{\text { água }}{\rightleftharpoons} \mathrm{O}_{2}(\mathrm{aq})
$$

\begin{tabular}{|c|c|}
\hline Pressão (atm) & Concentração $\mathbf{~ m o l} / \mathbf{L}$ de $\mathbf{O}_{\mathbf{2}}$ (aq) \\
\hline 1,05 & 0,00123 \\
\hline 4,60 & 0,00529 \\
\hline 5,91 & 0,00674 \\
\hline 8,55 & 0,00951 \\
\hline 9,86 & 0,01082 \\
\hline
\end{tabular}

\section{Questáo para a sala de aula}

Observando a tabela, você diria que a pressão afeta a concentraçáo de oxigênio que se encontra dissolvido na água? Como?

No processo de produçấo de ferro-gusa em usinas siderúrgicas ocorre a reaçăo:

$\mathrm{FeO}(\mathrm{s})+\mathrm{CO}(\mathrm{g}) \rightleftharpoons \mathrm{Fe}(\mathrm{s})+\mathrm{CO}_{2}(\mathrm{~g})$, cuja constante de equilíbrio $\mathrm{K}$ varia com a temperatura, conforme mostra a tabela a seguir:

\begin{tabular}{|c|c|c|c|c|}
\hline $\mathbf{T}\left({ }^{\circ} \mathbf{C}\right)$ & 700 & 800 & 900 & 1000 \\
\hline $\mathbf{K}$ & 0,678 & 0,552 & 0,466 & 0,403 \\
\hline
\end{tabular}


a) Escreva a expressão da constante de equilíbrio para essa transformaçấo.

b) O aumento da temperatura favorece ou desfavorece a obtenção de ferro metálico. Justifique.

Mergulhadores costumam utilizar misturas dos gases oxigênio e nitrogênio em seus cilindros. Essas misturas são conhecidas como Nitrox ou como EAN (Enriched Air Nitrox). As mais comuns são EAN32 - 32\% de oxigênio e $68 \%$ de nitrogênio - e EAN36 - 36\% de oxigênio e $64 \%$ de nitrogênio. Para alguns tipos de mergulho, que fogem do recreacional ou esportivo, são também usadas outras misturas de gases, como o Trimix, na qual, além do oxigênio e do nitrogênio, é usado o gás hélio. Mergulhadores também usam misturas chamadas Heliox, que nẩo contêm nitrogênio, somente oxigênio e hélio. A escolha da mistura vai depender da profundidade do mergulho e do seu tempo de duraçăo.

Por que, independentemente da mistura de gases escolhida, mergulhos a grandes profundidades devem levar em conta o tempo de descompressáo? Leve em conta que, a cada 10 metros abaixo da superfície do mar, a pressão aumenta em cerca de 1 atm e que a solubilidade de gases em água varia com a pressão.

Para responder a essa pergunta, analise um exemplo de um planejamento de mergulho que deverá permitir a exploraçáo durante 25 minutos de um navio naufragado a 73 metros de profundidade. Na tabela estâo explicitados o tempo de parada que os mergulhadores deverẫo fazer a diferentes profundidades durante a subida desse mergulho.

\begin{tabular}{|c|c|c|c|c|c|c|c|c|c|c|}
\hline $\begin{array}{c}\text { Profundidade } \\
(\mathbf{m})\end{array}$ & 30 & 27 & 24 & 21 & 18 & 15 & 12 & 9 & 6 & 3 \\
\hline $\begin{array}{c}\text { Tempo de } \\
\text { parada (min) }\end{array}$ & 1 & 1 & 2 & 3 & 4 & 6 & 8 & 13 & 16 & 27 \\
\hline
\end{tabular}


Observe que, neste mergulho, para que os mergulhadores possam explorar o navio naufragado por 25 minutos, deverão levar quase 1 hora e meia para retornar à superfície, a fim de que a descompressão possa ser feita de maneira adequada.

O que eu aprendi... 
I - Desenvolvimento histórico

Vimos no decorrer dos encontros algumas atividades envolvendo aspectos históricos contidas no material da rede estadual (Situação de Aprendizagem 02: Estudo da síntese e da produção industrial de amônia; Situação de Aprendizagem 04: Modelo atômico de Dalton: ideias sobre a constituição e transformação da matéria e Situação de Aprendizagem 01: Explicando 0 comportamento de materiais: modelos sobre a estrutura da matéria: 1.2 Evolução das ideias: do átomo de Dalton ao átomo de Rutherford-Bohr).

Há também uma outra atividade envolvendo a discussão sobre a elaboração da tabela periódica (Situação de Aprendizagem 01: A linguagem química e a construção histórica da Tabela Periódica: Atividade 2).

Gostaria de conversar com você a respeito delas.

1. O que você pensa sobre essas atividades? Costuma utilizá-las em sala de aula? Você faria alguma modificação nelas? Quais? Por quê?

2. Você acha importante ter esse tipo de abordagem em sala de aula? Por quê? 
a) sulfato de chumbo II;

b) ácido sulfúrico;

c) nitrato de sódio;

d) cloreto de cálcio;

e) ozônio.

\section{Atividade 2 - Classificação periódica dos elementos: uma atividade didática com abordagem histórica}

Nesta atividade, vamos conhecer como alguns cientistas propuseram uma organizaçáo para os elementos químicos.

\section{Exercício em sala de aula}

$\mathrm{Na}$ tabela a seguir são apresentadas algumas informaçốes sobre vários elementos químicos, conforme o exemplo:

- nome do elemento: sódio;

- símbolo do elemento: $\mathrm{Na}$;

- massa atômica (MA): 23 u;

- temperatura de fusão da substância simples a 1 atm (TF): $97,8^{\circ} \mathrm{C}$;

- temperatura de ebuliçấo da substância simples a 1 atm (TE): $882,9^{\circ} \mathrm{C}$;

- fórmula da substância simples: Na;

- fórmula da substância formada com o elemento hidrogênio: $\mathrm{NaH}$;

- fórmula da substância formada com o elemento oxigênio: $\mathrm{Na}_{2} \mathrm{O}$. 


\begin{tabular}{|c|c|c|}
\hline Sódio & Lítio & Potássio \\
\hline $\mathrm{Na}$ & $\mathrm{Li}$ & $\mathrm{K}$ \\
\hline MA: $23 \mathrm{u}$ & MA: 7 u & MA: 39 u \\
\hline TF: $97,8^{\circ} \mathrm{C}$ & TF: $180,5^{\circ} \mathrm{C}$ & TF: $63,6^{\circ} \mathrm{C}$ \\
\hline TE: $882,9^{\circ} \mathrm{C}$ & TE: $1347^{\circ} \mathrm{C}$ & TE: $774^{\circ} \mathrm{C}$ \\
\hline $\mathrm{Na}$ & $\mathrm{Li}$ & $\mathrm{K}$ \\
\hline $\mathrm{NaH}$ & $\mathrm{LiH}$ & $\mathrm{KH}$ \\
\hline $\mathrm{Na}_{2} \mathrm{O}$ & $\mathrm{Li}_{2} \mathrm{O}$ & $\mathrm{K}_{2} \mathrm{O}$ \\
\hline Magnésio & Cálcio & Carbono \\
\hline $\mathrm{Mg}$ & $\mathrm{Ca}$ & $\mathrm{C}$ \\
\hline MA: $24 \mathrm{u}$ & MA: $40 \mathrm{u}$ & MA: $12 \mathrm{u}$ \\
\hline TF: $648,8^{\circ} \mathrm{C}$ & TF: $839^{\circ} \mathrm{C}$ & TF: $3367^{\circ} \mathrm{C}$ \\
\hline TE: $2970{ }^{\circ} \mathrm{C}$ & TE: $1484^{\circ} \mathrm{C}$ & TE: $4827^{\circ} \mathrm{C}$ \\
\hline $\mathrm{Mg}$ & $\mathrm{Ca}$ & $\mathrm{C}$ \\
\hline $\mathrm{MgH}_{2}$ & $\mathrm{CaH}_{2}$ & $\mathrm{CH}_{4}$ \\
\hline $\mathrm{MgO}$ & $\mathrm{CaO}$ & $\mathrm{CO}_{2}$ \\
\hline Silício & Flúor & Cloro \\
\hline $\mathrm{Si}$ & $\mathrm{F}$ & $\mathrm{Cl}$ \\
\hline MA: $28 \mathrm{u}$ & MA: $19 \mathrm{u}$ & MA: 35 u \\
\hline TF: $1410^{\circ} \mathrm{C}$ & TF: $-219,6^{\circ} \mathrm{C}$ & TF: $-100{ }^{\circ} \mathrm{C}$ \\
\hline TE: $2355^{\circ} \mathrm{C}$ & TE: $-188^{\circ} \mathrm{C}$ & TE: $-34,6^{\circ} \mathrm{C}$ \\
\hline $\mathrm{Si}$ & $\mathrm{F}_{2}$ & $\mathrm{Cl}_{2}$ \\
\hline $\mathrm{SiH}_{4}$ & $\mathrm{HF}$ & $\mathrm{HCl}$ \\
\hline $\mathrm{SiO}_{2}$ & $\mathrm{OF}_{2}$ & $\mathrm{Cl}_{2} \mathrm{O}$ \\
\hline
\end{tabular}

Procure organizar os elementos em diferentes conjuntos, conforme as sugestóes a seguir:

a) Agrupe-os de acordo com as semelhanças das seguintes propriedades, justificando os critérios para esses agrupamentos: 
- temperatura de fusão da substância simples;

- temperatura de ebulição da substância simples.

b) Agrupe-os de acordo com as semelhanças das fórmulas das substâncias citadas, justificando os critérios para esses agrupamentos:

- substâncias simples (a 1 atm de pressão);

- substâncias formadas com o elemento hidrogênio;

- substâncias formadas com o elemento oxigênio.

c) Analisando as propriedades e os compostos formados, procure organizar os elementos em quatro grupos, explicando quais critérios foram utilizados para essa organizaçăo. 


\section{PESQUISA EM GRUPO}

Muitos cientistas se preocuparam em criar uma classificaçáo para os elementos químicos a fim de melhor estudá-los.

\section{A tabela de Mendeleev}

Veja a seguir a tabela de Mendeleev conforme ele a organizou.

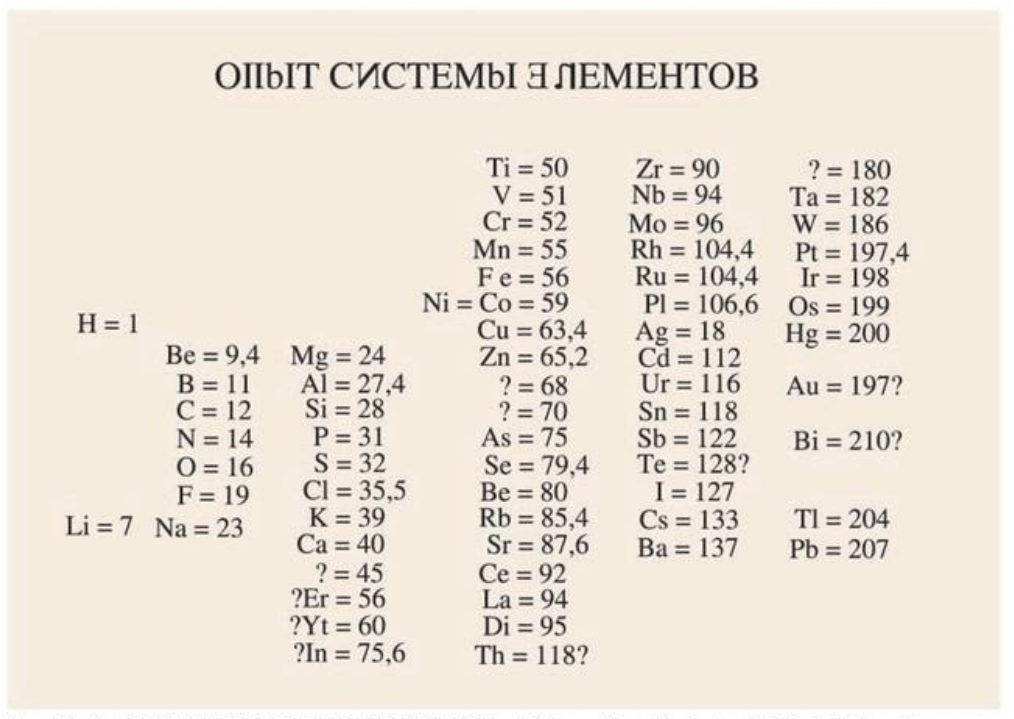

Extraída de: PETRIANOV, I. V.; TRIFONOV, D. N. A lei grandiosa. Tradução de Maria Helena Fortunato. Moscou: Mir, 1987, p. 15.

Esclarecimentos quanto aos pontos de interrogaçáo que aparecem na tabela de Mendeleev: (a) quando eles aparecem junto aos símbolos dos elementos ou junto aos valores de massa atômica, Mendeleev tinha dúvida quanto a serem esses os valores das massas atômicas; (b) quando eles aparecem antes do sinal de igualdade, Mendeleev acreditava que deveria haver um elemento com essa massa, que ainda năo havia sido descoberto.

\section{A tabela periódica atual}

Veja a seguir a tabela periódica atual, com as seguintes informaçóes:

- símbolo do elemento;

- nome do elemento;

- massa atômica do elemento. 


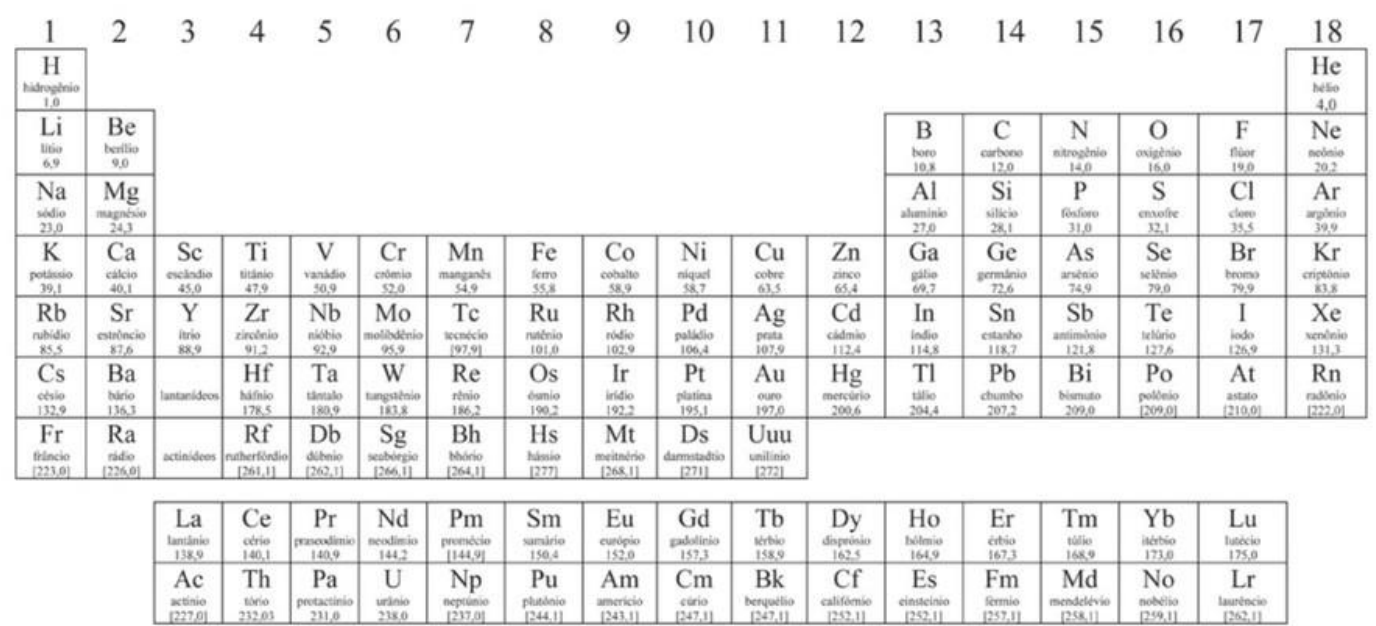

Seguindo as orientaçôes de seu professor, pesquise mais detalhes da história da tabela periódica ou da classificação dos elementos químicos. Essas informações podem ser encontradas em livros didáticos do Ensino Médio e em diversas páginas da internet. Destaque as principais informaçōes pesquisadas e apresente-as para a turma.

O que eu aprendi... 
ou seja, quando depararem com esse tipo de representação, saibam qual substância está sendo representada.

Para desenvolver os conceitos de substância simples e composta e avaliar a aprendizagem da representação simbólica das substâncias e dos elementos químicos, você pode propor questões como as apresentadas a seguir:

Substância simples é aquela formada por átomos de um único elemento e substância composta é aquela formada por átomos de mais de um elemento. Assim, entre as substâncias anteriores, indique quais são substâncias simples e quais são substâncias compostas.

Quantos átomos de cada elemento formam as partículas das seguintes substâncias: $\mathrm{H}_{2} \mathrm{O}_{2}$ (peróxido de hidrogênio, conhecido comumente como água oxigenada); $\mathrm{C}_{2} \mathrm{H}_{5} \mathrm{OH}$ (álcool etílico ou etanol); $\mathrm{CaCO}_{3}$ (carbonato de cálcio); $\mathrm{Ca}\left(\mathrm{HCO}_{3}\right)_{2}$ (hidrogenocarbonato de cálcio ou bicarbonato de cálcio); e $\mathrm{SO}_{2}$ (dióxido de enxofre)? (Veja o CA, exercícios 3 e 4. No CA, Atividade 1, também consta como Lição de Casa um exercício em que os alunos devem pesquisar as fórmulas de algumas substâncias e interpretá-las em termos de átomos constituintes.)

Atividade 2 - Classificação periódica dos elementos: uma atividade didática com abordagem histórica

Nesta atividade, pretende-se que os alunos tentem agrupar os elementos químicos considerando algumas de suas propriedades, uma estratégia que pode ser interessante para que compreendam como foi possível organizar a tabela periódica.

Antes de apresentar a classificação periódica dos elementos, sugere-se que você mostre aos alunos como a tabela periódica foi idealizada por Mendeleev. Para isso, peça aos alunos que, em grupos, reproduzam os cartões a seguir. Os cartões devem conter as seguintes informações: nome do elemento; símbolo; massa atômica (MA); temperatura de fusão (TF); temperatura de ebulição (TE); fórmula da substância simples formada por esse elemento a $1 \mathrm{~atm}$ de pressão; fórmulas das substâncias compostas com o elemento e o hidrogênio $(\mathrm{H})$; fórmulas das substâncias compostas com o elemento e o oxigênio $(\mathrm{O})$.

\begin{tabular}{|l|l|l|}
\hline Sódio & Lítio & Potássio \\
\hline $\mathrm{Na}$ & $\mathrm{Li}$ & $\mathrm{K}$ \\
\hline $\mathrm{MA}: 23 \mathrm{u}$ & $\mathrm{MA}: 7 \mathrm{u}$ & MA: $39 \mathrm{u}$ \\
\hline $\mathrm{TF}: 97,8^{\circ} \mathrm{C}$ & $\mathrm{TF}: 180,5^{\circ} \mathrm{C}$ & $\mathrm{TF}: 63,6{ }^{\circ} \mathrm{C}$ \\
\hline $\mathrm{TE}: 882,9{ }^{\circ} \mathrm{C}$ & $\mathrm{TE}: 1347^{\circ} \mathrm{C}$ & TE: $774{ }^{\circ} \mathrm{C}$ \\
\hline $\mathrm{Na}$ & $\mathrm{Li}$ & $\mathrm{K}$ \\
\hline $\mathrm{NaH}$ & $\mathrm{LiH}$ & $\mathrm{KH}$ \\
\hline $\mathrm{Na}_{2} \mathrm{O}$ & $\mathrm{Li} \mathrm{O}_{2}$ & $\mathrm{~K}_{2} \mathrm{O}$ \\
\hline
\end{tabular}




\begin{tabular}{|l|l|l|}
\hline Magnésio & Cálcio & Carbono \\
\hline $\mathrm{Mg}$ & $\mathrm{Ca}$ & $\mathrm{C}$ \\
\hline $\mathrm{MA}: 24 \mathrm{u}$ & $\mathrm{MA}: 40 \mathrm{u}$ & $\mathrm{MA}: 12 \mathrm{u}$ \\
\hline $\mathrm{TF}: 648,8^{\circ} \mathrm{C}$ & $\mathrm{TF}: 839^{\circ} \mathrm{C}$ & $\mathrm{TF}: 3367^{\circ} \mathrm{C}$ \\
\hline $\mathrm{TE}: 2970^{\circ} \mathrm{C}$ & $\mathrm{TE}: 1484^{\circ} \mathrm{C}$ & $\mathrm{TE}: 4827^{\circ} \mathrm{C}$ \\
\hline $\mathrm{Mg}$ & $\mathrm{Ca}$ & $\mathrm{C}$ \\
\hline $\mathrm{MgH}$ & $\mathrm{CaH}$ & $\mathrm{CH}$ \\
\hline $\mathrm{MgO}$ & $\mathrm{CaO}$ & $\mathrm{CO}$ \\
\hline $\mathrm{Silício}$ & $\mathrm{Flúor}$ & $\mathrm{Cloro}$ \\
\hline $\mathrm{Si}$ & $\mathrm{F}$ & $\mathrm{Cl}$ \\
\hline $\mathrm{MA}: 28 \mathrm{u}$ & $\mathrm{MA}: 19 \mathrm{u}$ & $\mathrm{MA}_{2} 35 \mathrm{u}$ \\
\hline $\mathrm{TF}: 1410^{\circ} \mathrm{C}$ & $\mathrm{TF}:-219,6{ }^{\circ} \mathrm{C}$ & $\mathrm{TF}:-100{ }^{\circ} \mathrm{C}$ \\
\hline $\mathrm{TE}: 2355^{\circ} \mathrm{C}$ & $\mathrm{TE}:-188^{\circ} \mathrm{C}$ & $\mathrm{TE}:-34,6{ }^{\circ} \mathrm{C}$ \\
\hline $\mathrm{Si}$ & $\mathrm{F} 2$ & $\mathrm{Cl}_{2}$ \\
\hline $\mathrm{SiH}$ & $\mathrm{HF}$ & $\mathrm{HCl}$ \\
\hline $\mathrm{SiO} 2$ & $\mathrm{OF}{ }_{2}$ & $\mathrm{Cl}_{2} \mathrm{O}$ \\
\hline
\end{tabular}

Após recortar cada cartão, pode ser simulado um jogo (CA, Atividade 2, exercício 1) no qual se organizem os elementos em conjuntos, de acordo com as seguintes regras:

1. Agrupar os elementos de acordo com as semelhanças das seguintes propriedades, justificando os critérios para esses agrupamentos:

a) temperatura de fusão;

b) temperatura de ebulição.

2. Agrupar os elementos de acordo com as semelhanças das fórmulas dos compostos formados, justificando os critérios para esses agrupamentos:

a) com hidrogênio;

b) com oxigênio.

3. Analisando as propriedades e os compostos formados, procurar organizar os elementos em quatro grupos, explicando como foi realizada a tarefa.

Nesta atividade, os alunos podem fazer livremente as associações dos elementos desde que consigam justificar o motivo dos agrupamentos. A intenção é que eles possam 
trabalhar criativamente e tenham uma ideia de como os cientistas poderiam classificar os elementos de acordo com suas propriedades e compostos formados.

Para dar continuidade a esta atividade, solicite aos alunos que pesquisem a respeito da história da tabela periódica ou da classificação dos elementos químicos (CA, Pesquisa em Grupo). Essas informações podem ser encontradas na maioria dos livros didáticos do Ensino Médio. Pode-se pedir que destaquem as principais informações pesquisadas e as apresentem para a turma. Este exercício poderá desenvolver habilidades de síntese e de organização das ideias.

Os pontos principais dessa pesquisa podem ser:

em 1829, Johann W. Döbereiner propõe a organização dos elementos em conjuntos de três, chamados de tríades;

- em 1862, Alexander B. de Chancourtois propõe a organização em espiral, chamada de parafuso telúrico;

- em 1864, John A. R. Newlands propõe a organização em grupos de oito elementos, chamada de lei das oitavas; em 1869, Dmitri I. Mendeleev realiza um trabalho meticuloso e propõe uma tabela que organiza os elementos de acordo com uma lei periódica, ou seja, por meio da semelhança de propriedades.

Podem-se destacar, também, dois fatores que contribuíram para que Mendeleev propusesse sua organização dos elementos químicos, atualmente conhecida como tabela periódica:

- na época, eram conhecidos muitos elementos químicos (mais de 60);

- as propriedades das substâncias simples formadas por esses elementos eram bastante conhecidas.

Esses conhecimentos possibilitaram a Mendeleev verificar a periodicidade das propriedades, permitindo a proposição de uma organização em ordem crescente de massas atômicas para a maioria dos elementos, invertendo a ordem de alguns em virtude da semelhança nas propriedades. Ao deixar espaços vazios na tabela, ele previu a existência de elementos químicos ainda não descobertos e descreveu as propriedades que esses elementos deveriam possuir.

A seguir, apresenta-se a tabela de Mendeleev conforme ele a organizou.

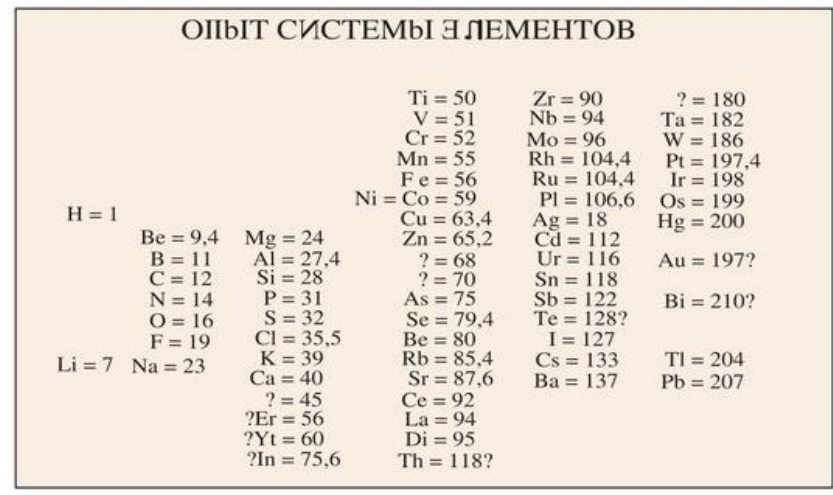

Extraída de: PETRIANOV, I. V.; TRIFONOV, D. N. A lei grandiosa. Tradução de Maria Helena Fortunato. Moscou: Mir, 1987, p. 15. 
Ao mostrar esta tabela aos alunos, incentive a discussão a respeito da linguagem universal da Química, pois mesmo que não compreendam o título da tabela, escrito em alfabeto cirílico, eles ainda podem reconhecer os elementos químicos que a integram, pois seus símbolos são derivados de seus nomes em latim.

Neste momento, seria interessante apresentar uma tabela periódica atual, a mais simples possível (conforme exemplo a seguir). A intenção é permitir-lhes conhecê-la e utilizá-la para consultar valores de massa atômica. Cabe lembrar que, nesta tabela, a ordem dos elementos é diferente da proposta por Mendeleev, pois sua organização se dá em ordem crescente de número atômico, e as massas não são mais calculadas tendo o hidrogênio como padrão, e sim o carbono 12 . Neste momento, essas informações não são adequadas para os alunos porque o modelo atômico que conhecem ainda é o de Dalton, ou seja, eles ainda não sabem o que são prótons, nêutrons e elétrons, conteúdo que só será abordado na $2^{a}$ série do Ensino Médio, bem como a retomada da tabela periódica com a sua organização atual.

Nesta atividade, é interessante que os alunos façam também o exercício de tentar agrupar os elementos químicos utilizando algumas de suas propriedades, para compreender como foi possível organizar a tabela periódica.

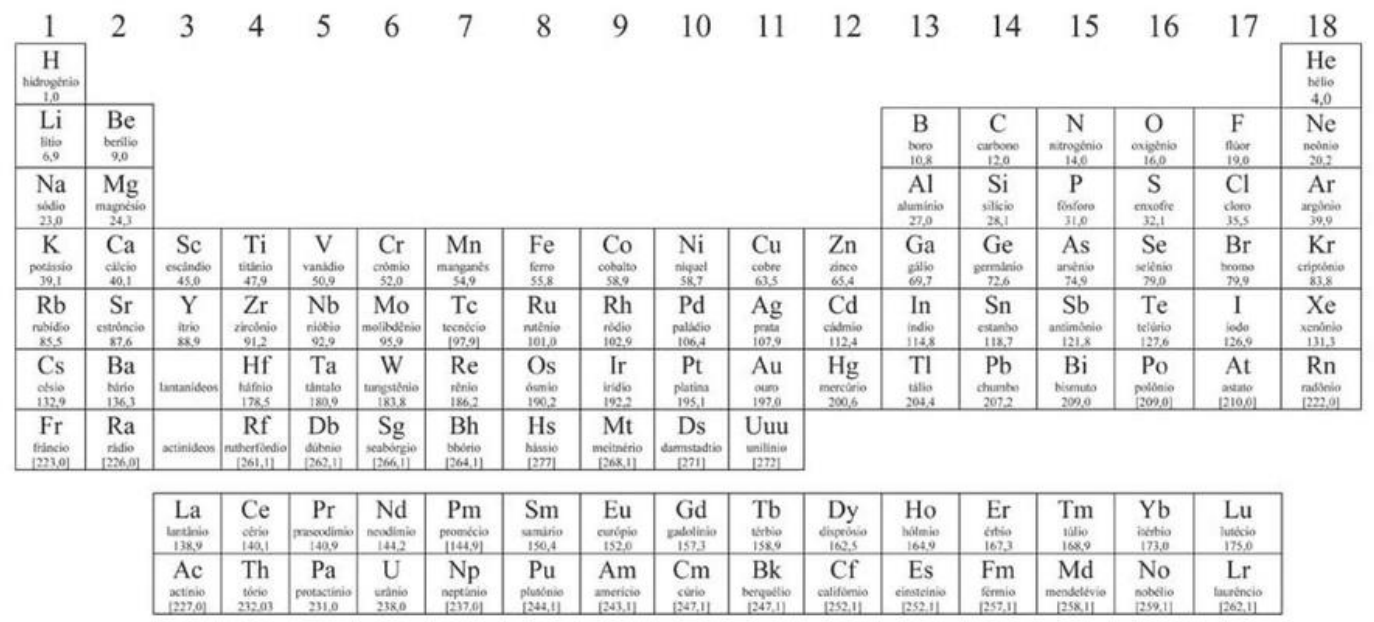

\section{Grade de avaliação da Situação de Aprendizagem 1}

Na Atividade 1, espera-se que os alunos compreendam a utilização da linguagem simbólica da Química, com a qual vêm se familiarizando desde o $1^{\circ}$ bimestre, e se habituem a utilizá-la na construção de suas explicações e argumentações científicas.
Além disso, espera-se que consigam relacionar as fórmulas das substâncias à sua constituição em relação aos átomos dos elementos químicos que a compõem, transitando com fluência entre o nível representacional e o microscópico.

Na questão da página 11, espera-se que indiquem as seguintes composições: 
$\mathbf{H}_{2} \mathbf{O}_{2}$ : dois átomos do elemento hidrogênio e dois átomos do elemento oxigênio;

$\mathrm{C}_{2} \mathrm{H}_{5} \mathrm{OH}$ : dois átomos do elemento carbono, seis átomos do elemento hidrogênio e um átomo do elemento oxigênio;

$\mathrm{CaCO}_{3}$ : um átomo do elemento cálcio, um átomo do elemento carbono e três átomos do elemento oxigênio;

$\mathrm{Ca}\left(\mathrm{HCO}_{3}\right)_{2}$ : um átomo do elemento cálcio, dois átomos do elemento hidrogênio, dois átomos do elemento carbono e seis átomos do elemento oxigênio;

$\mathrm{SO}_{2}$ : um átomo do elemento enxofre e dois átomos do elemento oxigênio.

Na Atividade 2, eles podem associar livremente os elementos com base em alguns critérios, que podem ser:

- estado físico à temperatura ambiente;

- temperaturas de fusão e de ebulição positivas e negativas;

- temperaturas de fusão e de ebulição altas, médias e baixas (talvez colocando alguns intervalos de valores);

- em relação aos compostos formados com oxigênio, é possível agrupá-los de acordo com o tipo de fórmula geral $\left(\mathrm{X}_{2} \mathrm{O}, \mathrm{OX}_{2}\right.$, $\mathrm{XO}, \mathrm{XO}_{2}$ );

- em relação aos compostos formados com hidrogênio, é possível agrupá-los de acordo com o tipo de fórmula geral ( $\mathrm{HX}, \mathrm{XH}$, $\mathrm{XH}_{2}, \mathrm{XH}_{4}$ ).
É possível que, ao agrupar os compostos formados com hidrogênio, cuja fórmula geral seja HX ou XH, bem como os formados com oxigênio, cuja fórmula geral seja $\mathrm{X}_{2} \mathrm{O}$ ou $\mathrm{OX}_{2}$, os alunos não os classifiquem em grupos distintos, pois a ordem em que os elementos são escritos nas fórmulas pode não ser um critério para agrupá-los separadamente. Espera-se, porém, que, no item 3, eles separem os elementos em quatro grupos (alcalinos, alcalinoterrosos, família do carbono e halogênios) ${ }^{*}$, mesmo que possam ter dificuldade em classificar o cloro no grupo dos halogênios, por ele apresentar a mesma fórmula com o oxigênio $\left(\mathrm{Cl}_{2} \mathrm{O}\right)$ que aqueles pertencentes aos elementos do grupo dos alcalinos $\left(\mathrm{X}_{2} \mathrm{O}\right)$. Neste caso, pode-se sugerir que os alunos verifiquem não só os compostos formados, mas também as temperaturas de fusão e de ebulição para tentar decidir se há mais proximidade entre o cloro e o flúor ou entre ele e o grupo dos alcalinos.

Nesta atividade também procura-se mostrar que a tabela periódica é fruto da construção coletiva de diversos cientistas que contribuíram, ao longo dos séculos XIX e $\mathrm{XX}$, para a descoberta dos elementos químicos, a determinação de suas propriedades e sua organização, e, por fim, o formato de tabela que conhecemos atualmente. Por meio do agrupamento de alguns elementos químicos em função de suas propriedades, foi possível vivenciar um dos princípios que nortearam a construção das primeiras tabelas periódicas. A abordagem histórica da organização dos elementos químicos possibilita identificar que, além das propriedades, a ordenação em função das massas atômicas é um segundo critério para a construção dessas tabelas.

\footnotetext{
* Os nomes dos grupos ou famílias dos elementos químicos são apresentados apenas como informação para o professor. Entretanto, se considerar interessante, você pode comentar que os grupos obtidos pelos estudantes correspondem a tais grupos na tabela periódica atual.
} 
Gostaria de lhe apresentar uma outra atividade (Atividade G) envolvendo a elaboração da Tabela Periódica por Mendeleev.

3. Qual a sua opinião sobre as discussões propostas na parte 1 a partir do texto sobre o desenvolvimento da Tabela Periódica?

4. O que você acha da parte 2? Essa é uma discussão interessante de ser realizada com os estudantes? Por quê? 


\section{Atividade G}

Tema: O desenvolvimento da Tabela Periódica - Um "quebra-cabeças" com muitas peças

\section{Parte 01 - Leitura de texto sobre o desenvolvimento da Tabela Periódica}

Durante a leitura do texto, os seguintes pontos podem ser discutidos:

- Como os cientistas interpretam criativamente os dados e desenvolvem padrões para explicar os dados.

- A reunião dos químicos no Congresso de Karlsruhe para encontrar uma posição consensual em relação à linguagem e às representações utilizadas na química, enfatizando a importância dos encontros entre cientistas para discutir e divulgar seus trabalhos, bem como para debater problemas teóricos ou metodológicos relativos à sua área de pesquisa.

- A importante participação no Congresso do químico italiano Stanislao Cannizzaro, que retomou algumas ideias de Amedeo Avogadro elaboradas cerca de 50 anos antes, mostrando como ideias científicas prévias podem tornar-se úteis de uma maneira imprevista.

- Criatividade e imaginação de Mendeleev e os muitos modos de se fazer ciência.

- Como Mendeleev chegou aos detalhes específicos de suas previsões sobre os elementos gálio, germânio e escândio.

- Lei periódica.

\section{Parte 02 - Teorias concorrentes}

- O professor discute o que é lei e se as leis são ou não semelhantes em diferentes disciplinas.

- Depois discute os sentidos de leis na vida cotidiana e nas ciências físicas.

- O professor apresenta duas teorias aos alunos:

- Teoria 01: A lei periódica e a lei da gravitação são de mesma natureza. O termo "lei" pode ser usado com o mesmo significado para ambas.

- Teoria 02: A lei periódica e a lei de gravitação são de naturezas diferentes. O termo "lei" não pode ser usado com o mesmo significado para ambas.

- Depois, pede que os alunos escolham uma delas e justifiquem suas escolhas.

- No final, o professor enfatiza as características da lei periódica e a diferença das leis na química e na física. 


\section{APÊNDICE B - Quadro 10 - Temas utilizados para a elaboração do roteiro de entrevista}

\begin{tabular}{|c|c|c|c|}
\hline Temas & Motivos da escolha & $\begin{array}{l}\text { Aspectos da natureza da } \\
\text { ciência e da química } \\
\text { relacionados ao tema }\end{array}$ & Trechos de Diretrizes Curriculares Nacionais \\
\hline $\begin{array}{l}\text { RELAÇÕES COM A } \\
\text { SOCIEDADE }\end{array}$ & 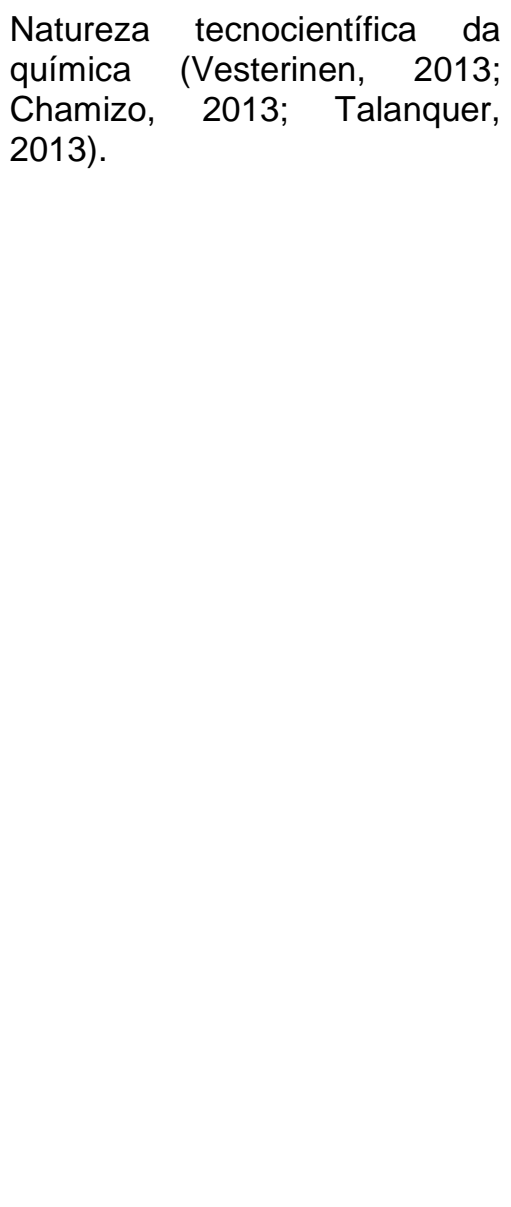 & $\begin{array}{l}\text { Relações da química com } \\
\text { indústria e comércio. } \\
\text { Demandas sociais: pesquisas } \\
\text { feitas para fins práticos ou } \\
\text { comerciais. } \\
\text { Ligação entre pesquisa pura e } \\
\text { aplicada. } \\
\text { Múltiplos impactos do } \\
\text { desenvolvimento científico. } \\
\text { Implicações do consumo e da } \\
\text { produção de substâncias } \\
\text { químicas. } \\
\text { Imagem pública da química. } \\
\text { Financiamento de pesquisa. } \\
\text { Influência cultural. }\end{array}$ & $\begin{array}{l}\text { Reconhecer as relações entre o desenvolvimento científico } \\
\text { e tecnológico da Química e aspectos sócio-político-culturais } \\
\text { (Brasil, 1999, p. 39). } \\
\text { Reconhecer os limites éticos e morais que podem estar } \\
\text { envolvidos no desenvolvimento da Química e da tecnologia } \\
\text { (Brasil, 1999, p. 39). } \\
\text { Reconhecer o papel do conhecimento químico no } \\
\text { desenvolvimento tecnológico atual, em diferentes áreas do } \\
\text { setor produtivo, industrial e agrícola; por exemplo, na } \\
\text { fabricação de alimentos, corantes, medicamentos e novos } \\
\text { materiais (Brasil, 2002, p. 92). } \\
\text { Identificar a presença do conhecimento químico na cultura } \\
\text { humana contemporânea, em diferentes âmbitos e setores } \\
\text { (...). (Brasil, 2002, p. 92). } \\
\text { Compreensão do papel desempenhado pela Química no } \\
\text { desenvolvimento tecnológico e a complexa relação entre } \\
\text { ciência e tecnologia ao longo da história (Brasil, 2006, } \\
\text { p.115). } \\
\text { Reconhecimento do papel do conhecimento químico no } \\
\text { desenvolvimento tecnológico atual em diferentes áreas do } \\
\text { setor produtivo, industrial e agrícola (Brasil, 2006, p.115). } \\
\text { Compreensão da interdependência entre desenvolvimento } \\
\text { científico e tecnológico e desenvolvimento tecnológico e } \\
\text { sociedade (Brasil, 2006, p.115). }\end{array}$ \\
\hline
\end{tabular}




\begin{tabular}{|c|c|c|c|}
\hline & & & $\begin{array}{l}\text { Reconhecimento da influência da ciência e da tecnologia } \\
\text { sobre a sociedade e desta última sobre o progresso } \\
\text { científico e tecnológico e as limitações e possibilidades de } \\
\text { se usar a ciência e a tecnologia para resolver problemas } \\
\text { sociais (Brasil, 2006, p.115). } \\
\text { Compreensão das interações entre a ciência e a tecnologia } \\
\text { e os sistemas políticos e do processo de tomada de decisão } \\
\text { sobre ciência e tecnologia, englobando defesa nacional e } \\
\text { políticas globais (Brasil, 2006, p.115). } \\
\text { Identificação de aspectos estéticos, criativos e culturais da } \\
\text { atividade científica; os efeitos do desenvolvimento científico } \\
\text { sobre a literatura e as artes, e a influência da humanidade } \\
\text { na ciência e na tecnologia (Brasil, 2006, p.115). }\end{array}$ \\
\hline $\begin{array}{l}\text { MODELOS E } \\
\text { MODELAGEM }\end{array}$ & $\begin{array}{l}\text { Principal atividade dos } \\
\text { químicos (Justi, 2010). } \\
\text { Fornece contextos } \\
\text { para abolevantes } \\
\text { epistemológicos } \\
\text { 2001). }\end{array}$ & 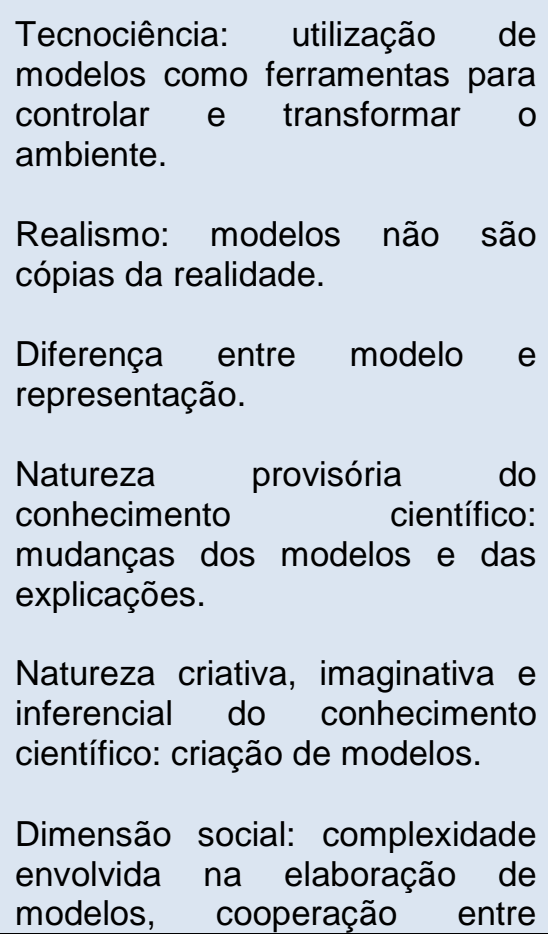 & $\begin{array}{l}\text { Reconhecer, utilizar, interpretar e propor modelos para } \\
\text { situações-problema, fenômenos ou sistemas naturais ou } \\
\text { tecnológicos (Brasil, 2002, p.91). } \\
\text { Reconhecer, nas limitações de um modelo explicativo, a } \\
\text { necessidade de alterá-lo; por exemplo, perceber até onde o } \\
\text { modelo de Rutherford foi suficiente e por quais razões } \\
\text { precisou dar lugar a outra imagem do átomo (Brasil, 2002, } \\
\text { p.91). } \\
\text { Reconhecer modelos explicativos de diferentes épocas } \\
\text { sobre a natureza dos materiais e suas transformações; por } \\
\text { exemplo, identificar os principais modelos de constituição da } \\
\text { matéria criados ao longo do desenvolvimento científico } \\
\text { (Brasil, 2002, p.91). } \\
\text { Os assuntos tratados neste tema podem propiciar o } \\
\text { desenvolvimento de competências gerais tais como: (...) } \\
\text { reconhecer a necessidade e os limites de modelos } \\
\text { explicativos relativos à natureza dos materiais e suas } \\
\text { transformações; reconhecer e compreender a química como } \\
\text { resultado de uma construção humana, inserida na história e } \\
\text { na sociedade (Brasil, } 2002, \text { p.96). }\end{array}$ \\
\hline
\end{tabular}




\begin{tabular}{|c|c|c|c|}
\hline & & cientistas. & $\begin{array}{l}\text { Compreensão do mundo, do qual a Química é parte } \\
\text { integrante, por meio dos problemas que ela consegue } \\
\text { resolver e dos fenômenos que podem ser descritos por seus } \\
\text { conceitos e modelos (Brasil, 2006, p.115). } \\
\text { Reconhecimento do caráter provisório e incerto das teorias } \\
\text { científicas, das limitações de um modelo explicativo e da } \\
\text { necessidade de alterá-lo, avaliando as aplicações da ciência } \\
\text { e levando em conta as opiniões controvertidas dos } \\
\text { especialistas (Brasil, 2006, p.115). }\end{array}$ \\
\hline EXPERIMENTAÇÃO & $\begin{array}{l}\text { Atividade científica (Vesterinen, } \\
\text { 2013). } \\
\text { Eixo central da química } \\
\text { (Lemes, 2013). } \\
\text { Ambientes autênticos de } \\
\text { aprendizagem em educação } \\
\text { científica (Schumacher \& } \\
\text { Reiners, 2013). }\end{array}$ & $\begin{array}{l}\text { Tecnociência: síntese (novas } \\
\text { substâncias) e análise química. } \\
\text { Relação entre as evidências } \\
\text { experimentais, os conceitos e os } \\
\text { modelos químicos. } \\
\text { Papel da instrumentação. } \\
\text { Relação entre os mundos micro e } \\
\text { macroscópico. } \\
\begin{array}{l}\text { Natureza criativa, inferencial e } \\
\text { imaginativa. } \\
\text { Orientado por teorias prévias. } \\
\text { Dimensão social: cooperação e } \\
\text { colaboração, métodos } \\
\text { resultados } \\
\text { negociados. socialmente }\end{array}\end{array}$ & $\begin{array}{l}\text { (...) os dados obtidos em demonstrações, em visitas, em } \\
\text { relatos de experimentos ou no laboratório devem permitir, } \\
\text { através de trabalho em grupo, discussões coletivas, que se } \\
\text { construam conceitos e se desenvolvam competências e } \\
\text { habilidades. (Brasil, 1999, p.36). } \\
\text { Ainda na elaboração das atividades, deve-se considerar } \\
\text { também o desenvolvimento de habilidades cognitivas, tais } \\
\text { como controle de variáveis, tradução da informação de uma } \\
\text { forma de comunicação para outra, como gráficos, tabelas, } \\
\text { equações químicas, a elaboração de estratégias para a } \\
\text { resolução de problemas, tomadas de decisão baseadas em } \\
\text { análises de dados e valores, como integridade na } \\
\text { comunicação dos dados, respeito às ideias dos colegas e } \\
\text { às suas próprias e colaboração no trabalho coletivo (Brasil, } \\
\text { 1999, p.37). } \\
\text { Reconhecimento da ciência não como um corpus rígido e } \\
\text { fechado, mas como uma atividade aberta, que está em } \\
\text { contínua construção, a qual não é justificada somente por } \\
\text { critérios racionais e cognitivos, pois esses critérios são } \\
\text { também construídos socialmente (Brasil, 2006, p.115). } \\
\text { (...) é essencial que as atividades práticas (...) permitam } \\
\text { ricos momentos de estudo e discussão teórico/prática que, } \\
\text { transcendendo os conhecimentos de nível fenomenológico } \\
\text { e os saberes expressos pelos alunos, ajudem na }\end{array}$ \\
\hline
\end{tabular}




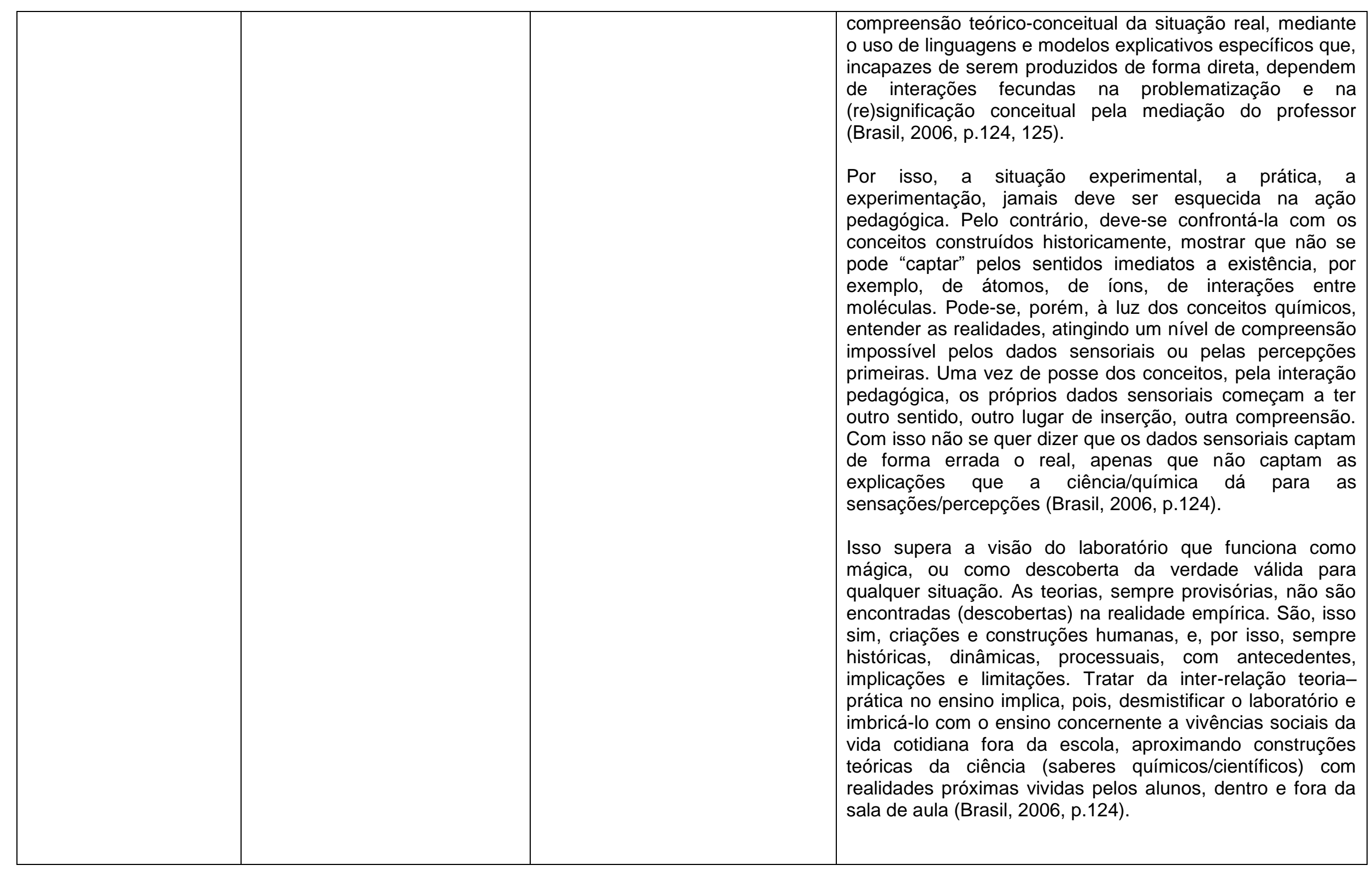




\begin{tabular}{|c|c|c|c|}
\hline REDUCIONISMO & $\begin{array}{l}\text { Importância das classificações } \\
\text { e aspectos qualitativos em } \\
\text { química (Erduran, 1999; } \\
\text { Lemes, 2013; Erduran e Scerri, } \\
2002 ; \quad \text { Izquierdo-Aymerich, } \\
2013 \text { ). } \\
\text { Consequências para o ensino } \\
\text { de química: supervalorização } \\
\text { de algoritmos e modelos } \\
\text { quantitativos (Lemes, 2013). }\end{array}$ & $\begin{array}{l}\text { Relação entre estrutura } \\
\text { molecular e composição. } \\
\text { Linguagem química, níveis de } \\
\text { representação e conceitos } \\
\text { circulares. } \\
\text { Aspectos qualitativos, relacionais } \\
\text { e classificatórios: modelos que } \\
\text { explicam mais os aspectos } \\
\text { qualitativos. } \\
\text { Leis na química. }\end{array}$ & $\begin{array}{l}\text { Assim como os outros campos do conhecimento, a Química } \\
\text { utiliza também uma linguagem matemática associada aos } \\
\text { fenômenos macro e microscópicos. O domínio dessa } \\
\text { linguagem servirá para desenvolver competências e } \\
\text { habilidades referentes ao estabelecimento de relações } \\
\text { lógico empíricas, lógico-formais, hipotético-lógicas e de } \\
\text { raciocínio proporcional. Mais uma vez, vale explicitar que } \\
\text { algoritmos e "regrinhas" simplesmente memorizados não } \\
\text { desenvolvem essas competências e habilidades (Brasil, } \\
\text { 1999, p. 34). }\end{array}$ \\
\hline $\begin{array}{l}\text { DESENVOLVIMENTO } \\
\text { HISTÓRICO }\end{array}$ & $\begin{array}{l}\text { Proporciona reflexões sobre } \\
\text { aspectos da natureza da } \\
\text { ciência e da química (Porto, } \\
\text { 2010). }\end{array}$ & $\begin{array}{l}\text { Tecnociência: propicia uma } \\
\text { compreensão de aspectos } \\
\text { característicos do conhecimento } \\
\text { químico, como o papel dos } \\
\text { instrumentos, das classificações, } \\
\text { reducionismo etc. } \\
\text { Natureza provisória do } \\
\text { conhecimento científico. } \\
\text { Natureza criativa, inferencial e } \\
\text { imaginativa. } \\
\text { Aspectos sociais e relações com } \\
\text { a sociedade. }\end{array}$ & $\begin{array}{l}\text { (...) o conhecimento químico não deve ser entendido como } \\
\text { um conjunto de conhecimentos isolados, prontos e } \\
\text { acabados, mas sim uma construção da mente humana, em } \\
\text { contínua mudança. A História da Química, como parte do } \\
\text { conhecimento socialmente produzido, deve permear todo o } \\
\text { ensino de química, possibilitando ao aluno a compreensão } \\
\text { do processo de elaboração desse conhecimento, com seus } \\
\text { avanços, erros e conflitos (Brasil,1999, p.31). } \\
\text { A consciência de que o conhecimento científico é assim } \\
\text { dinâmico e mutável ajudará o estudante e o professor a } \\
\text { terem a necessária visão crítica da ciência. Não se pode } \\
\text { simplesmente aceitar a ciência como pronta e acabada e os } \\
\text { conceitos atualmente aceitos pelos cientistas e ensinados } \\
\text { nas escolas como "verdade absoluta" (Brasil, 1999, p. 31). } \\
\text { Perceber o papel desempenhado pela Química no } \\
\text { desenvolvimento tecnológico e a complexa relação entre } \\
\text { ciência e tecnologia ao longo da história; por exemplo, } \\
\text { perceber que a manipulação do ferro e suas ligas, empírica } \\
\text { e mítica, tinha a ver, no passado, com o poder do grupo } \\
\text { social que a detinha, e que hoje, explicada pela ciência, } \\
\text { continua relacionada a aspectos políticos e sociais (Brasil, } \\
2002, \text { p. 92). }\end{array}$ \\
\hline
\end{tabular}




\begin{tabular}{|l|l|l|}
\hline & & $\begin{array}{l}\text { É fundamental que se mostre através da história, as } \\
\text { transformações das ideias sobre constituição da matéria, } \\
\text { contextualizando-as. A simples cronologia sobre essas } \\
\text { ideias, como é geralmente apresentada no ensino, é } \\
\text { insuficiente, pois pode dar uma ideia equivocada da ciência } \\
\text { e da atividade científica, segundo a qual a ciência se } \\
\text { desenvolve de maneira neutra, objetiva e sem conflitos, } \\
\text { graças a descobertas de cientistas, isoladas do contexto } \\
\text { social, econômico ou político da época (Brasil, 2002, p. 96). } \\
\text { Reconhecimento e compreensão da ciência e da tecnologia } \\
\text { químicas como criação humana, inseridas, portanto, na } \\
\text { história e na sociedade em diferentes épocas (Brasil, 2006, } \\
\text { p. 115). } \\
\text { Compreensão do papel desempenhado pela Química no } \\
\text { desenvolvimento tecnológico e a complexa relação entre } \\
\text { ciência e tecnologia ao longo da história. (Brasil, 2006, p. } \\
115) .\end{array}$ \\
\hline
\end{tabular}




\section{APÊNDICE C - Termo de consentimento livre e esclarecido}

Concordo em participar, como voluntário, da pesquisa na área de Ensino de Química que tem como pesquisador responsável Marcos Paulo Hirayama, aluno do Programa Interunidades em Ensino de Ciências da Universidade de São Paulo, que pode ser contatado pelo e-mail e pelos telefones e . O presente trabalho tem em vista a realização de entrevistas com professores de química, com o intuito de conhecer as suas concepções acerca do ensinar e aprender química, bem como a respeito de algumas atividades didáticas envolvendo o ensino sobre essa ciência. Minha participação consistirá em conceder uma entrevista que será gravada e transcrita. Compreendo que esse estudo possui finalidade de pesquisa, e que os dados obtidos serão divulgados seguindo as diretrizes éticas da pesquisa, assegurando, assim, minha privacidade. Sei que posso retirar meu consentimento quando eu quiser, e que não receberei nenhum pagamento por essa participação.

Nome:

Assinatura

São Paulo, de 2014 


\section{ANEXO A - Normas de transcrição segundo Preti (1999)}

\begin{tabular}{|c|c|}
\hline Ocorrências & Sinais \\
\hline Incompreensão de palavras ou segmentos & ( ) \\
\hline Hipótese do que se ouviu & (hipótese) \\
\hline $\begin{array}{l}\text { Truncamento (havendo homografia, usa-se acento } \\
\text { indicativo da tônica e/ou timbre) }\end{array}$ & I \\
\hline Entonação enfática & maiúscula \\
\hline Prolongamento de vogal e consoante (como s, r) & $\begin{array}{c}\text { ::podendo } \\
\text { aumentar para } \\
\text { :.:: ou mais }\end{array}$ \\
\hline Silabação & - \\
\hline Interrogação & $?$ \\
\hline Qualquer pausa & $\ldots$ \\
\hline Comentários descritivos do transcritor & ((minúscula)) \\
\hline $\begin{array}{l}\text { Comentários que quebram a sequência temática da } \\
\text { exposição; desvio temático }\end{array}$ & ---- \\
\hline Superposição, simultaneidade de vozes & $\begin{array}{l}\text { Ligando as } \\
\text { linhas }\end{array}$ \\
\hline $\begin{array}{l}\text { Indicação de que a fala foi tomada ou interrompida em } \\
\text { determinado ponto. }\end{array}$ & $(\ldots)$ \\
\hline Citações literais ou leituras de textos, durante a gravação & " " \\
\hline
\end{tabular}


Observações:

- Iniciais maiúsculas: só para nomes próprios ou para siglas.

- Fáticos: ah, éh, ahn, ehn, uhn, tá.

- Nomes de obras ou nomes comuns estrangeiros são grifados.

- Números: por extenso.

- Não se indica o ponto de exclamação.

- Não se anota o cadenciamento da frase.

- Podem-se combinar sinais. Por exemplo: oh:......(alongamento e pausa).

- Não se utilizam sinais de pausa, típicos da língua escrita, como ponto-evírgula, ponto final, dois pontos, vírgula. As reticências marcam qualquer tipo de pausa.

- Nos excertos extraídos das transcrições, presentes no corpo do trabalho, o sinal (...) também foi utilizado para omitir trechos das entrevistas que não estavam diretamente relacionados com os temas identificados. 